\title{
"التماس أولياء الأمور للمعلومات حول مشكلات أطفالهم من مواقع التواصل الإجتماعى والإثباعات المتحققة " دراسـة تطبيقية فى ضوء مدخلى التماس المعلومات والإستخدامات والإشباعات
}

\author{
د/ وفاء السبد خضر \\ مدرس الإعلام التريوى " صحافة "كلية التربية النوعية - جامعة طنطاء
}

الملخص

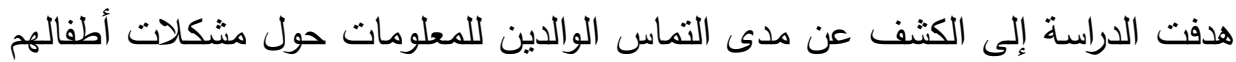

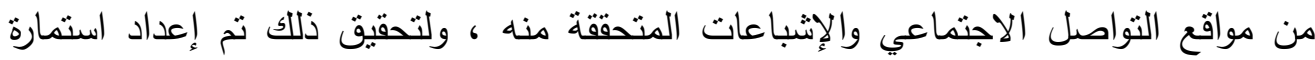

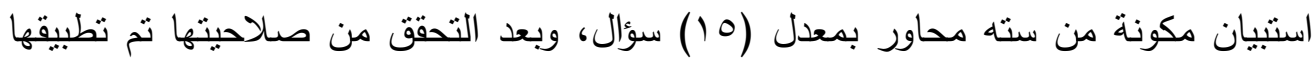

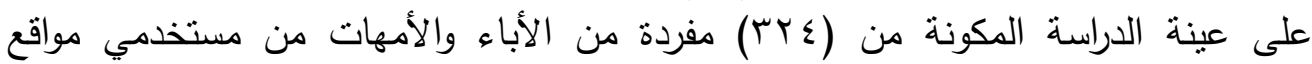

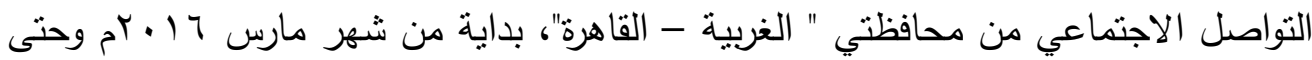

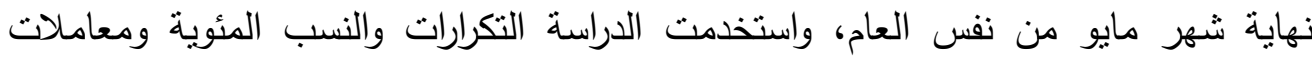

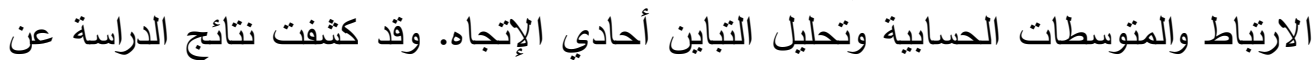

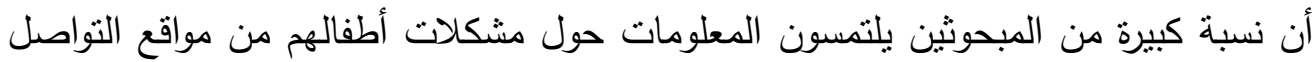

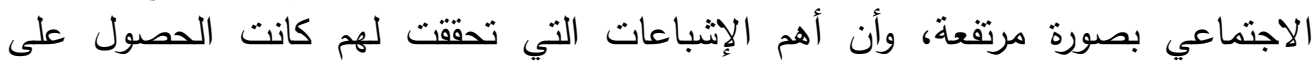

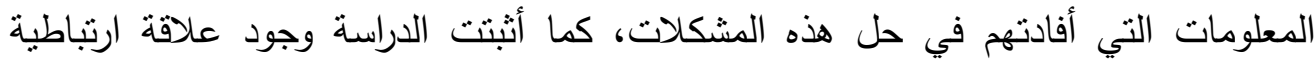

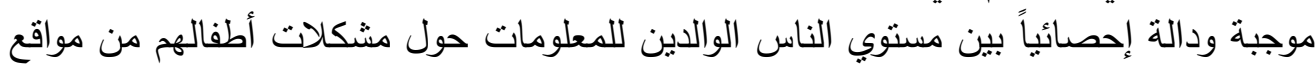
التواصل الاجتماعي والإشباعات المتحققة لهم نتيجة هذا الإنيات لإلتماس.

\section{Parents Information Seeking About Their Children's Problems From The Social Media And The Resulted Satisfactions \\ Applies study using (information seeking, uses and satisfaction theory)}

This study aimed at revealing the extent of parent's information seeking about their children's problems from the social media and the resulted satisfaction. A questionnaire form was designed from six axes, after its validation it was applied to a sample of (324) parents (who are using social media) residing in Cairo and Gharbiya Governorates from $1^{\text {st }}$ March $31^{\text {st }}$ May 2016. The study used Frequency, percentages, correlation coefficients, arithmetic averages, and one-way contrast analysis.

A great percentage of the respondents seeked information about their children's problems from the social media with high frequency, the most important satisfaction they had was that they found the information that helped them solving those problems. There was a positive and statistically significant correlation between parent's information seeking about their children's problems from the social media and the resulted satisfactions. 
المقدمة:

يشعر الوالدين بسعادة بالغة عند ميلاد أطفالهم، وبداية إحساسهم بمشاعر الوالدية، ولكن

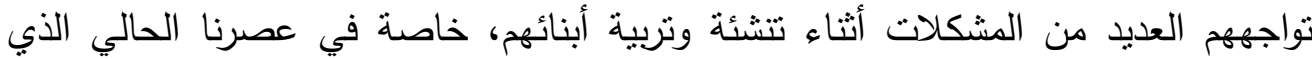

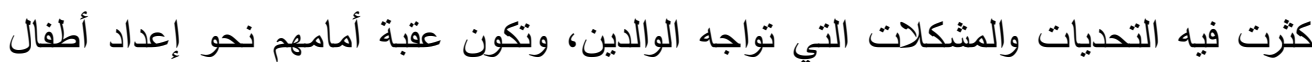

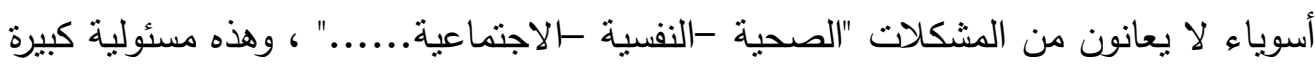
تلقى على عاتقهم. إن الوالدين هم أكثر الناس حباً لأبنائهم وحرصاً على تربيتهم وتتشئتهم وحل مشاكلهم

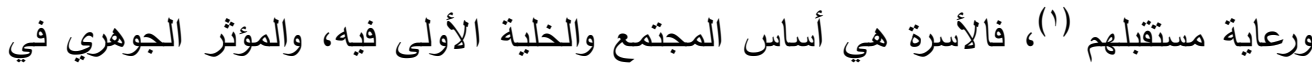
شخصية وسلوك الطفل، فتصرفات الطفل سواء كانت حسنة أم سيئة تعزي إلى دور الأسرة في تربيته وتتشئته (r)، فدور المربي المعاصر يكمن في مساعدة الطفل النامي على بلورة إنسانيته

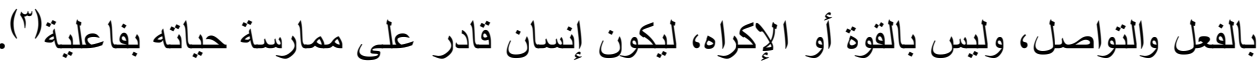

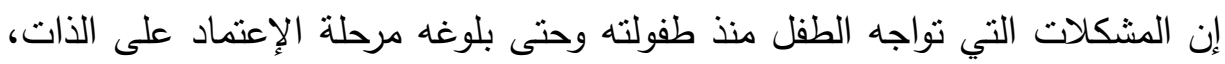

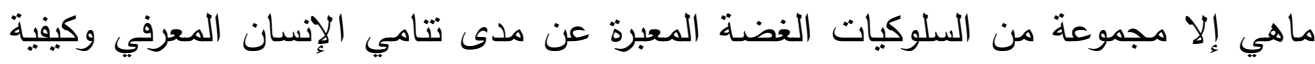

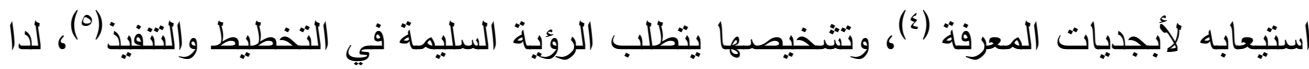
يحاول الوالدين البحث بشتى الطرق عن حلول لـشكلات أبنائهم مثل: "الذهاب إلى فئى الأطباء

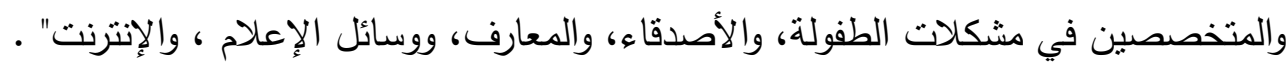

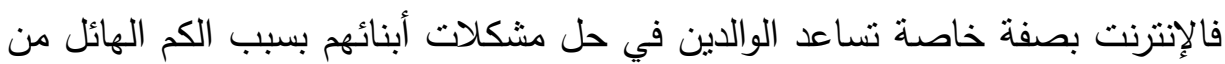

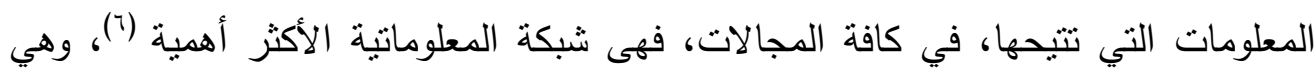

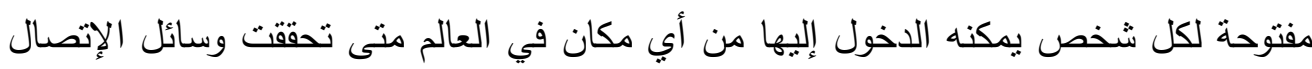

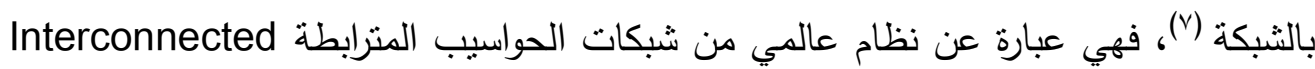

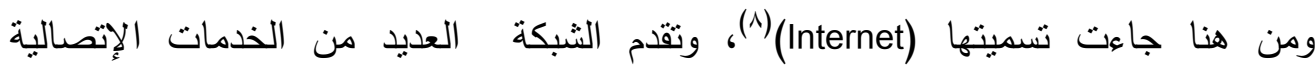

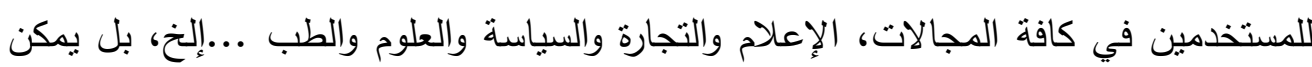

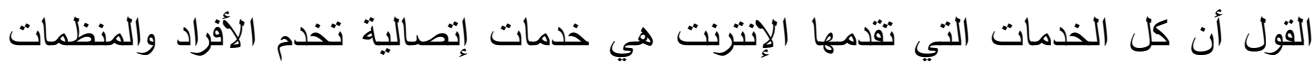
الرسمية والمدنية والمؤسسات على حد سواء (9).

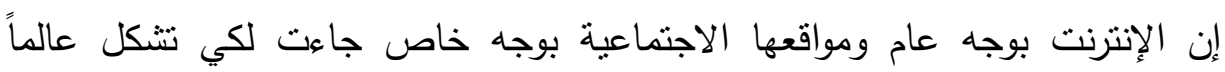

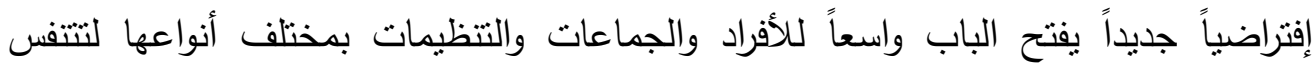

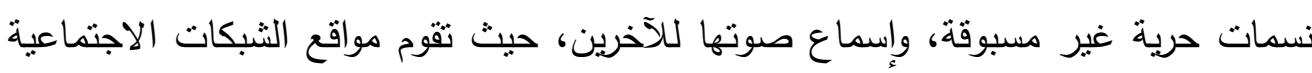

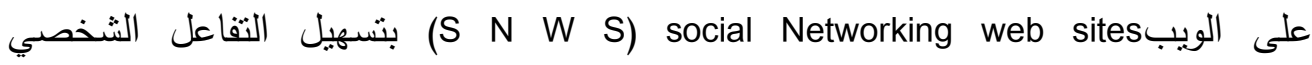
-yahoo -Twitter -facebook بصورة متزايدة عبر العالم منل Interpersonal Interaction -windows live spaces -My space 
طبيعيا للعلاقات الإجتماعية الحقبقة، حيث أنها تربط شبكات الأفراد الذين قد لا يتشاركون

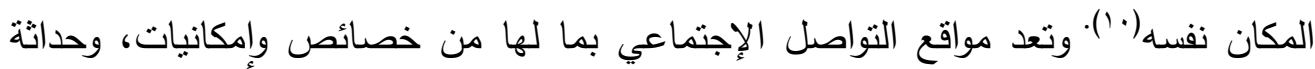

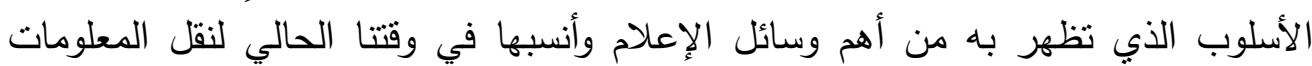

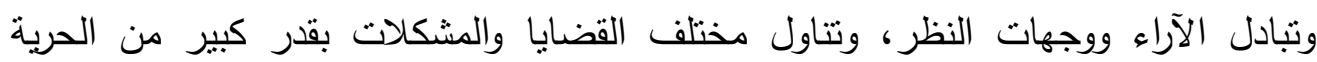

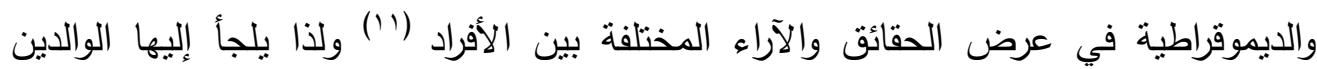
لإلتماس المعلومات التي قد تساعدهم فى حل مشكلات أبنائهر حتى قبل الذهاب الذاب إلى الألى الأطباء

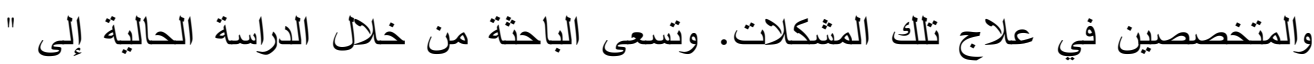

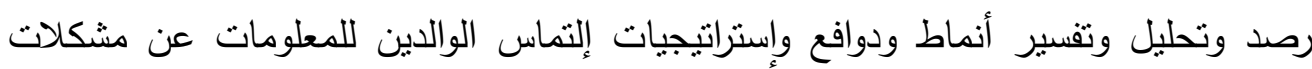

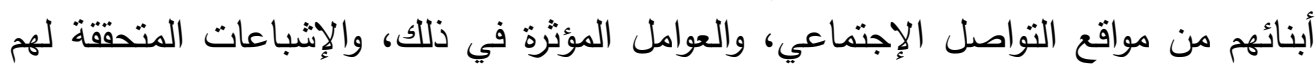

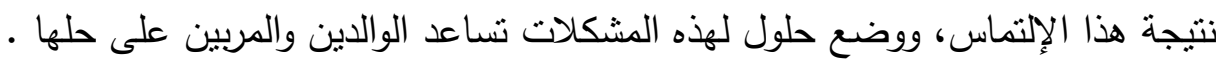

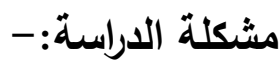

إن تتشئة أطفال أسوياء يتمكنون من العيش سعداء لمن أصعب المهام وأثققها على الصى الوالدين(r') والأمر لا بتطلب تربيتهم فحسب، بل مساعدتهم على إكتساب المرونة في مواجهة

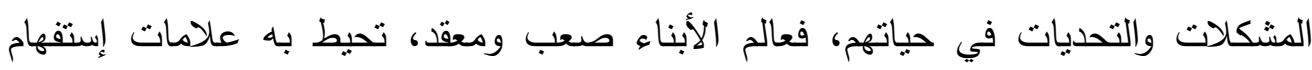

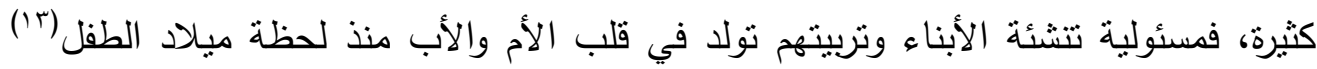

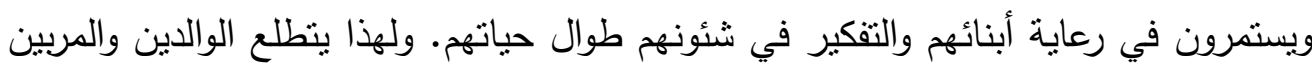

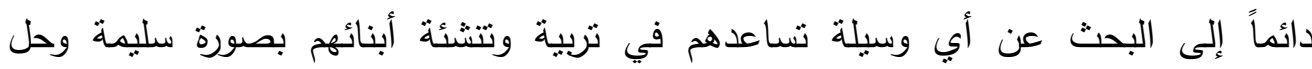

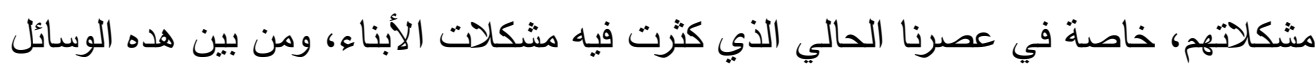

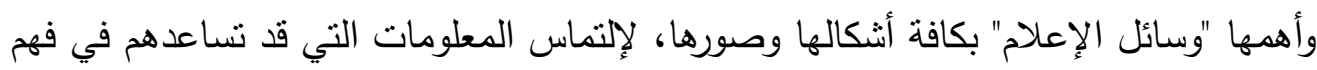

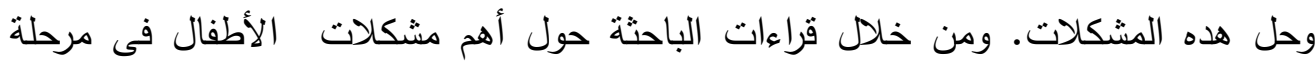

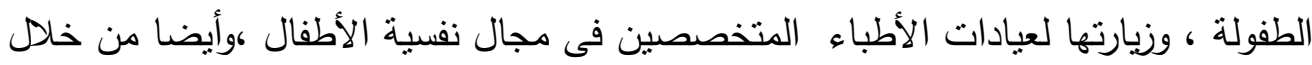

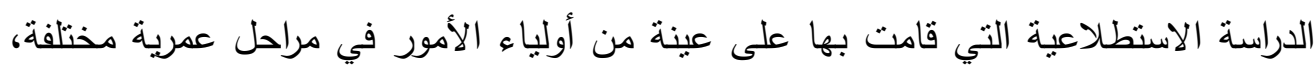

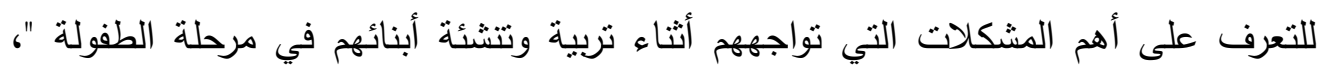

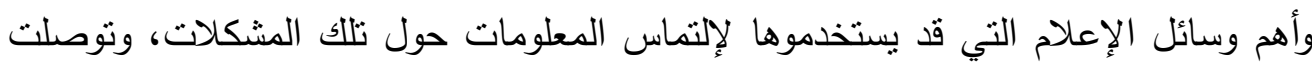

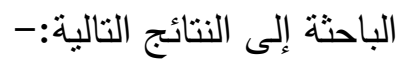
1- أن أهم وأكثر المشكلات التي يعاني منها الأطفال في مرحلة الطفولة، هي مشكلات: "

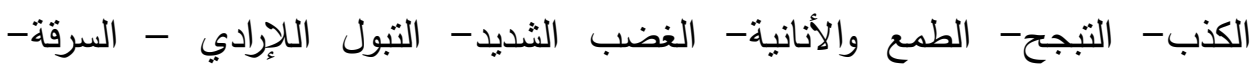
العدوانية- الخوف- عدم الطاعة والاعتراض الدائم- النشاط الزائد وقلة التركيز - الثتعور بالنقص والانطواء- الغيرة الثديدة " وغيرها من المشكلات ، لكن هذه هي أكثرها شيوعاً بينهم. 
r- أن الوالدين يشعرون بمرارة شديدة وألم نفسي بسبب هذه المشكلات التي تواجه أطفالهم

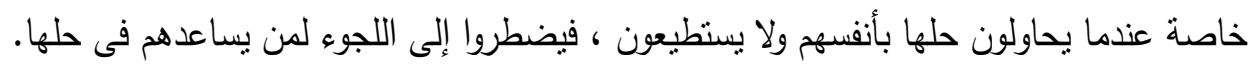

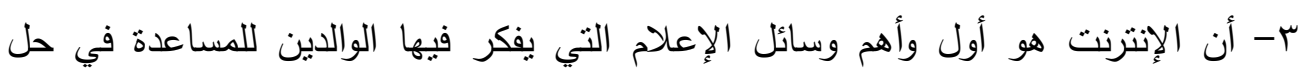

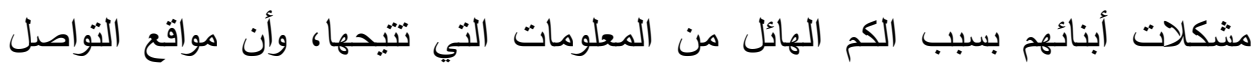

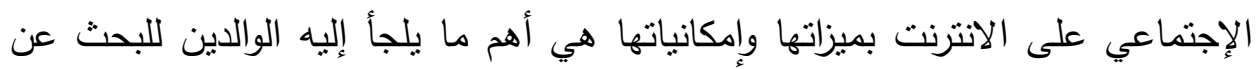

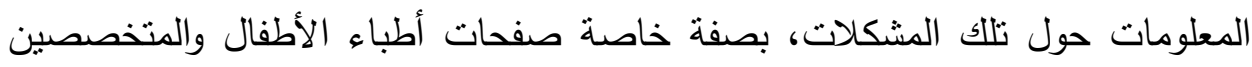
في مجال الطفولة ولهم صفحات معروفة على مواقع التواصل الإجتماعي، ثم الاصدقاء

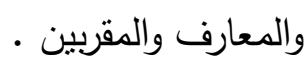
ع-يذهب الوالدين إلى عيادات أطباء نفسية الأطفال عند فنشهم في حل مشكلات أبنائهم بالطرق السابقة . عابن وبناءاً على ما سبق أمكن بلورة المشكلة البحثية للاراسة في : " الكثف عن مدى إلتماس

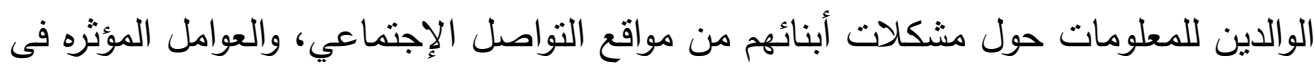

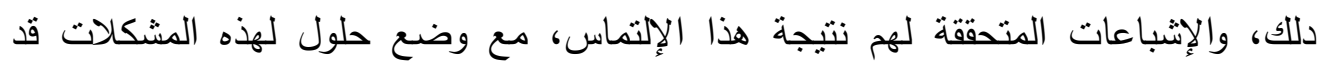
تساعد الوالدين والمربين " .

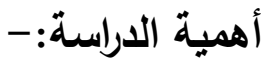

\section{أهمية الدراسة المعرفية:}

ا-تتعدد مواقع التواصل الإجتماعي على شبكة الإنترنت، مما يجعلها من أهم وسائل تبادل الآراء

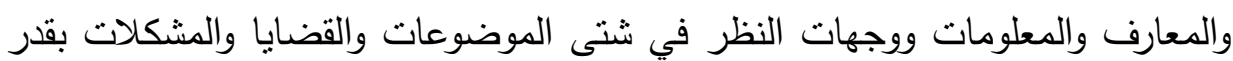

$$
\text { كبير من الحرية دون قيود. }
$$

r-استخدام نظرية إلتماس المعلومات في الدراسة الحالية، حيث لاحظت الباحثة ندرة

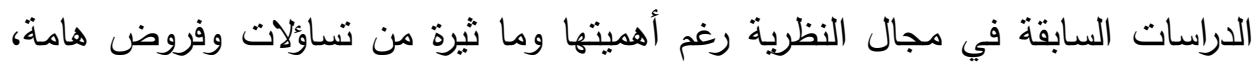
بالإضافة إلى نظرية الإستخدامات والإثباعات، لرصد الإثباعات المتحققة للوالدين،

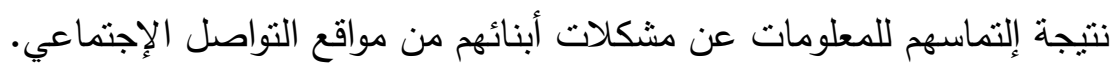
ب-رصد أهم المشكلات التي يعاني منها الأطفال في مرحلة الطفولة ، والتي قد تكون عائن عائقاً أمام النمو السوي لهم، وقد تؤئز على حياتهم المستقبلية إذ لم يتم معالجتها.

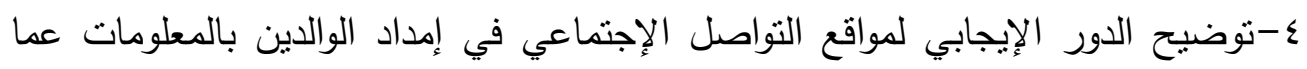

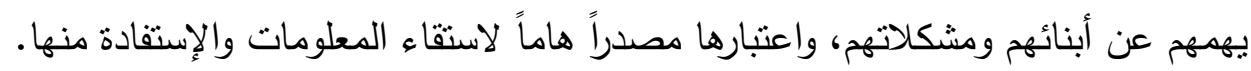


ا ـ أهمية وسائل الإعلام الجديدة، بصفة خاصة مواقع التواصل الإجتماعي والنمو الهائل

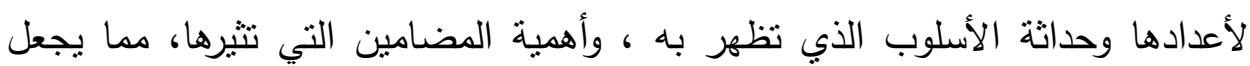

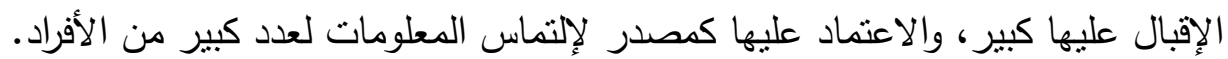

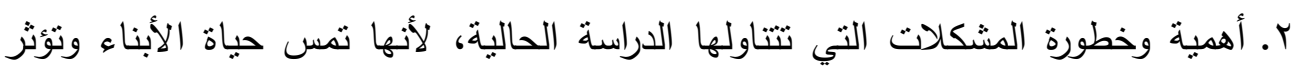

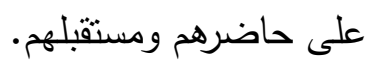
r. نركز الدراسة الحالية على الأسرة المصرية، ومشكلات الأبناء، باعتبارهم الأمل والمستقبل

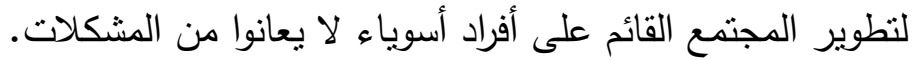

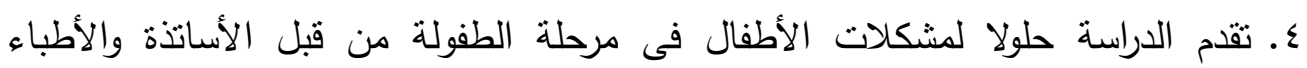

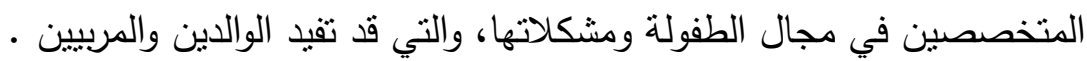

$$
\text { الإطار النظري للاراسة:- }
$$

تعتمد الدراسة الحالية على نظريتي " إلتماس المعلومات- والاستخدامات والإثباعات" وهما يفسران كيفية استخدام الوالدين لوسائل الإعلام لإلتماس المعلومات من خلالها ، واستراتيجيات

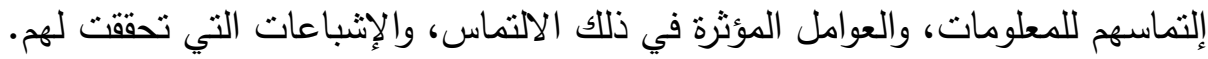
1 - نظرية إلتماس المعلومات (Information seekig theory) تهتم نظرية إلتماس المعلومات بتفسير سلوك الفرد في بحثة عن المعلومات من

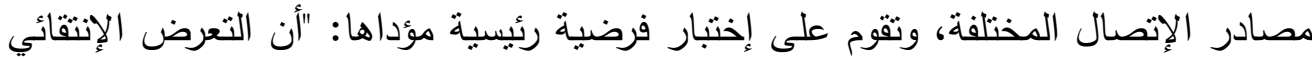

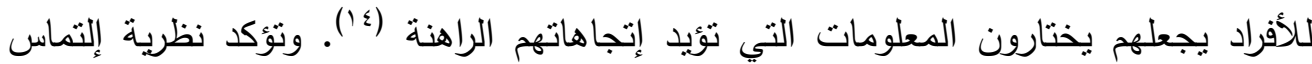

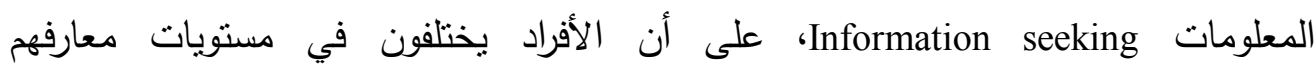

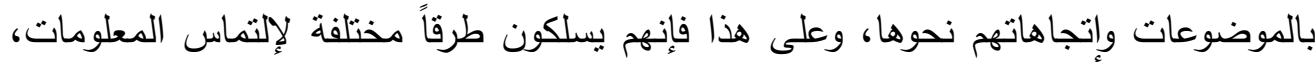

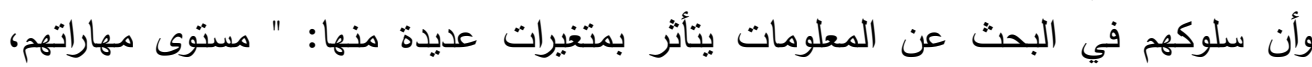

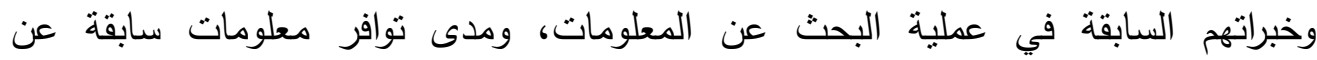
الموضوع، والوقت المتاح لهم (10).

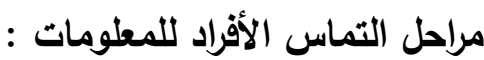

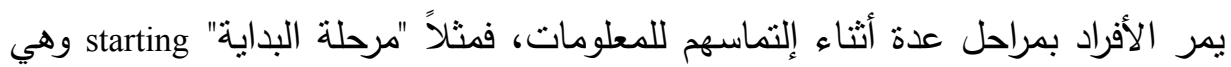

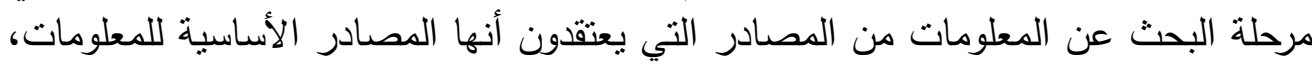

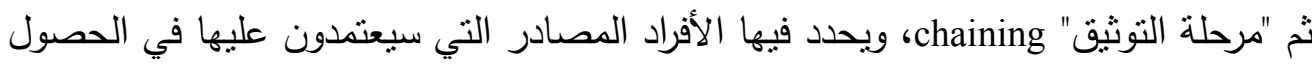

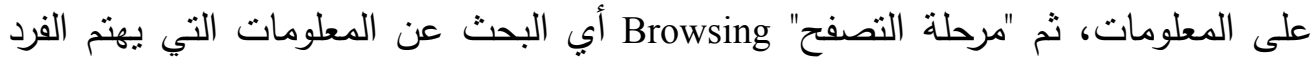

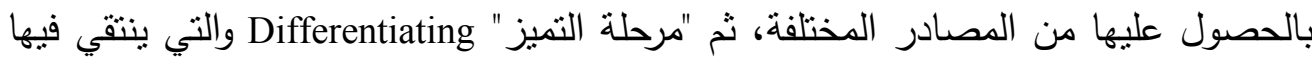
الفرد المصدر بناءاً على نوعية وتميز المعلومات التي يقدمها المصدر، ثم "مرحلة المراقبة" فئه 
ويتابع فيها الفرد مصادر المعلومات التي قد حددها في المراحل السابقة، ثم

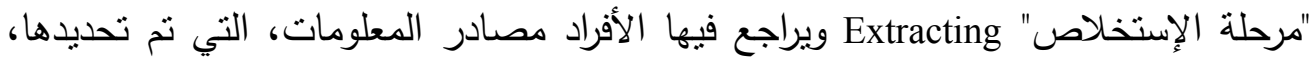

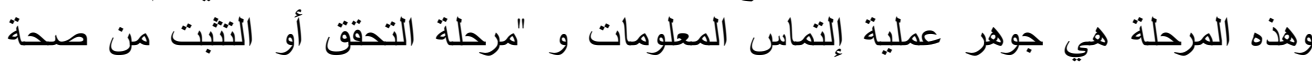

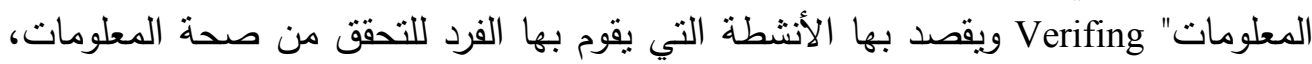

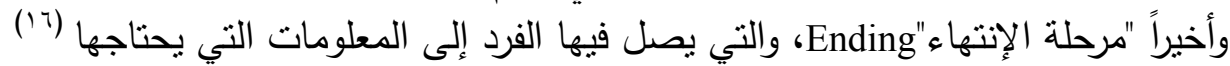
العوامل المؤثثرة في إلتماس الأفراد للمعلومات

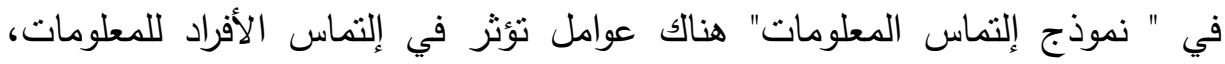

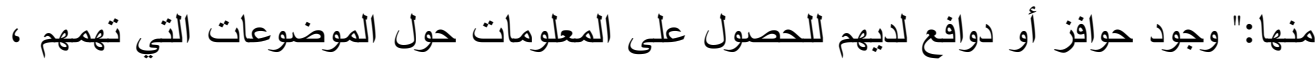

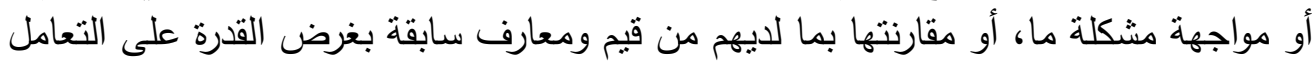

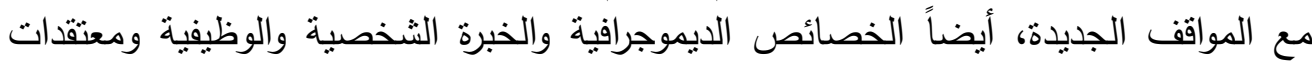

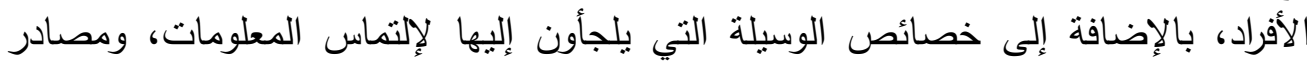

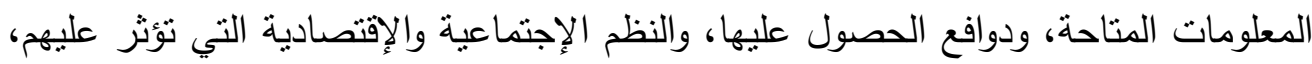

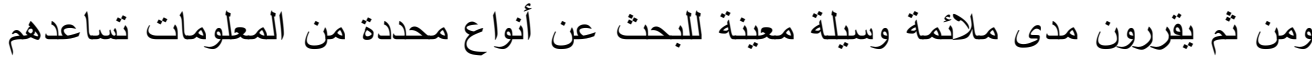

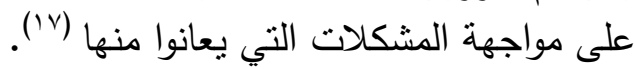

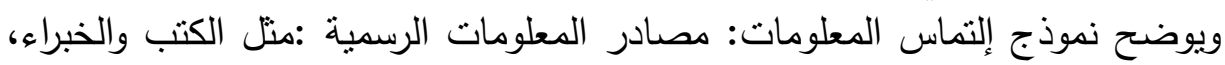

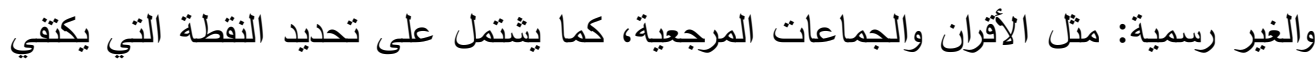

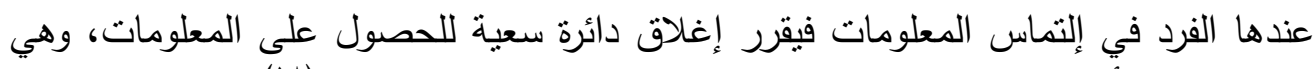

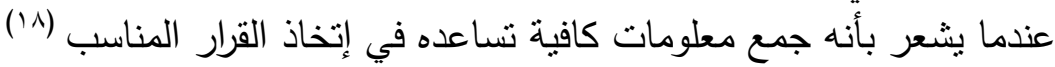

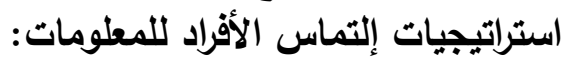

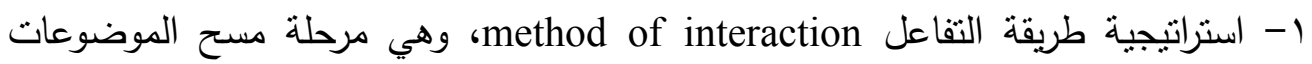
بهدف الوصول إلى معلومات عنها.

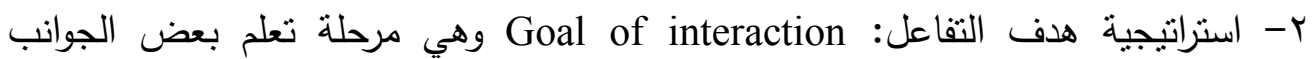

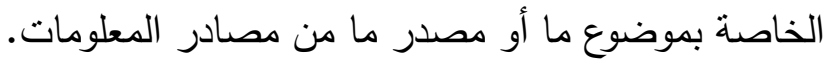

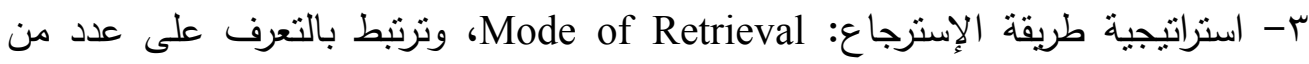

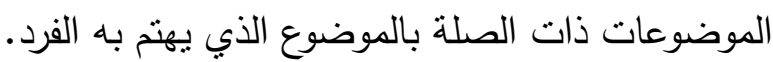

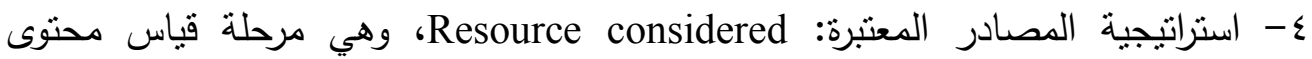
المعلومات للتأكد من دقتها (19 (1). وتعتمد الدراسة الحالية على نظرية "إلتماس المعلومات" من وسائل الإعلام لمناسبتها

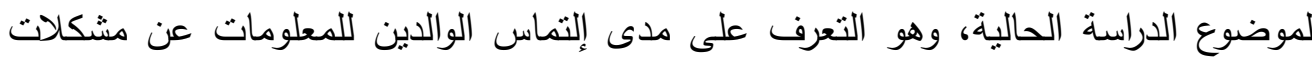

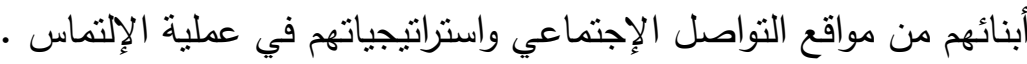

\section{r-نظرية الاستخدامات والإشباعات: (uses and Gratifications Theory) :}

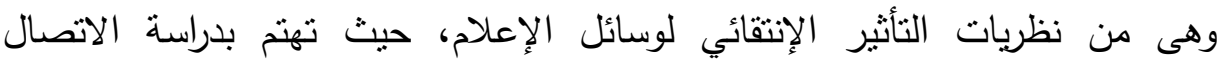

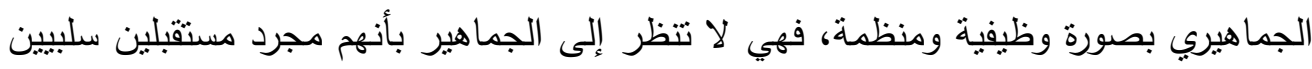


لرسائل الإتصال وإنما يختارون بوعي وسائل الإتصال التي يرغبون في التعرض لها، ونوع

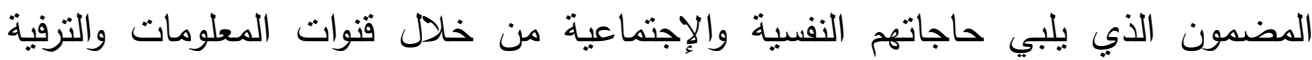

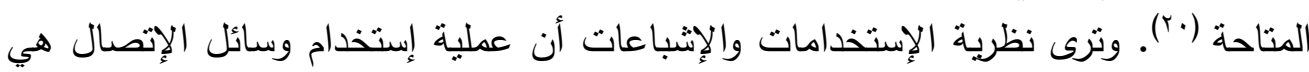

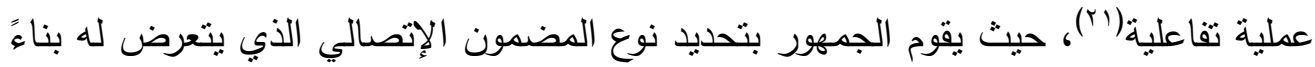

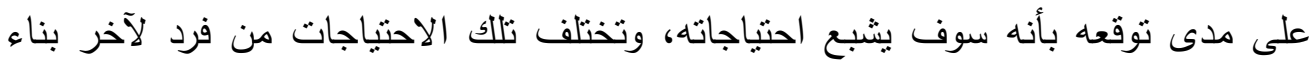

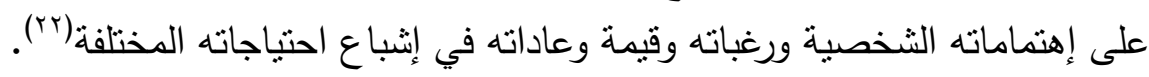
احتياجات الجمهور من وسائل الإعلام: حدد "كاتز وجروفيتش وهاس" احتياجات الأفراد من وسائل الإعلام في خمس فئات هي الاعلمات

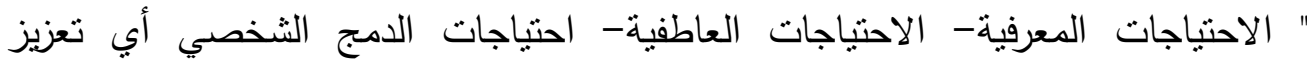
المصداقية والتقة والاستقرار والمكانة - احتباجات الدمج الإجتماعي أي التواصل مع الأسرة

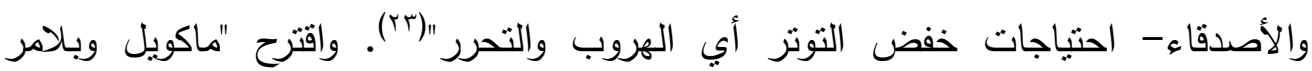

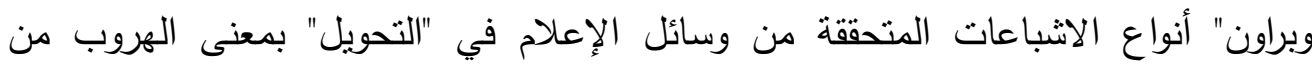

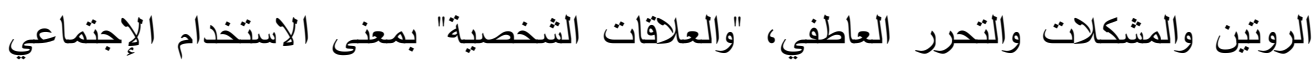

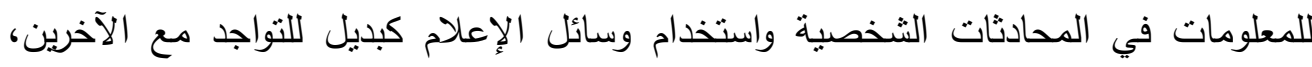

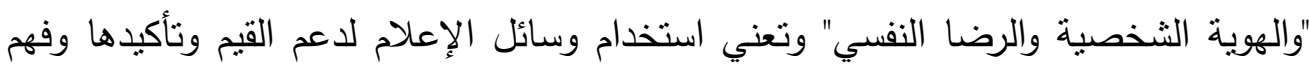
الذات وإكتثاف الواقع، "ومراقبة البيئة" بمعنى الحصول على المعلومات عن الإنى الثياء التي

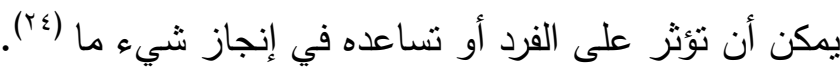

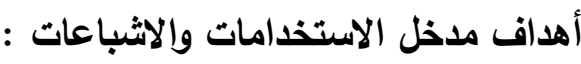

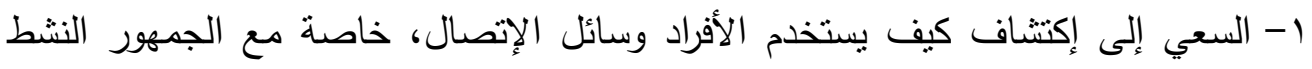
الذي يستطيع أن يختار ويستخدم الوسائل التي تنبع حاجاته.

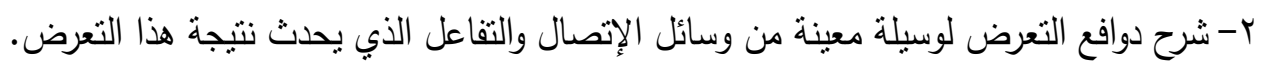

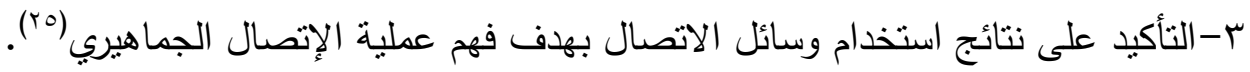
فروض نظرية الاستخدامات والاشباعات: في نموذج " كانز وزملائه" تقوم نظرية الاستخدامات والاشباعات الاتشبات على خمسة فروض رئيسية، هي:

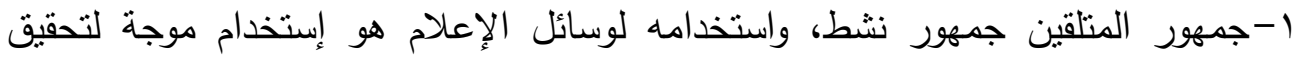
أهداف معينة. r-يمنلك أعضاء الجمهور المبادرة في تحديد العلاقة بين إثباع الحاجات واختبار وسائل معينة برى أنها تشبع حاجاته. 
ب-تتافس وسائل الإعلام مصادر أخرى لإثباع الحاجات، منل الاتصال الثخصي أو المؤسسات الأكاديمية أو غيرها، فالعلاقة بين الجمهور ووسائل الإعلام تتأثر بعوامل بيئية

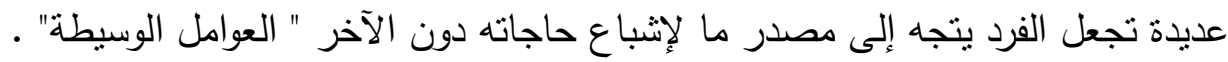

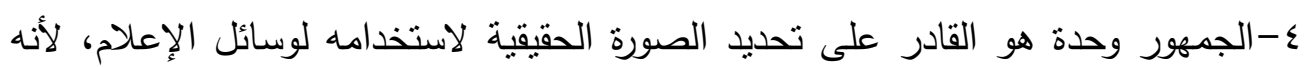

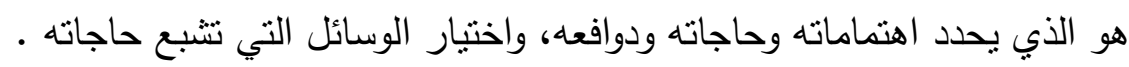

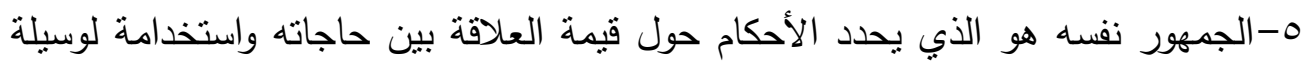

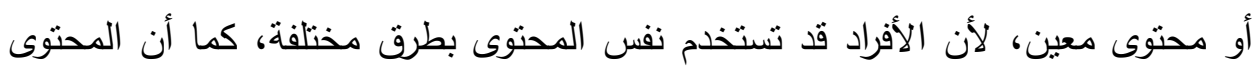

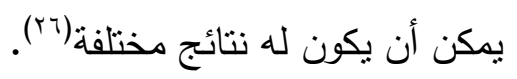

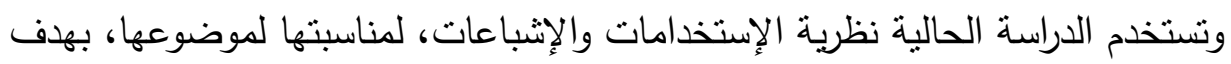

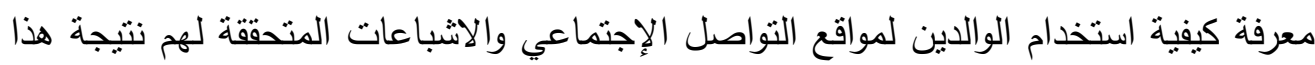

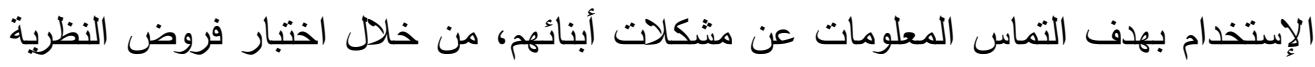

في الدراسة الحالية.

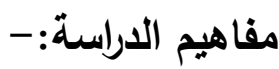

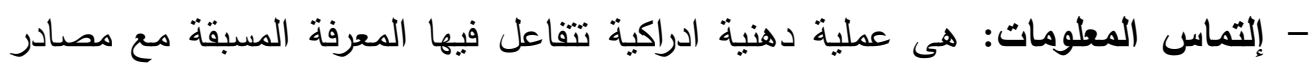

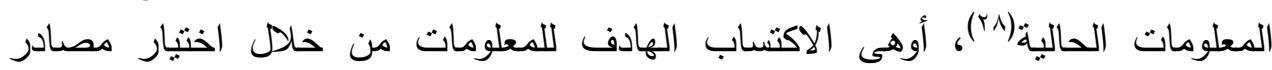

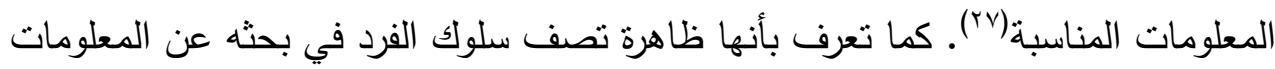

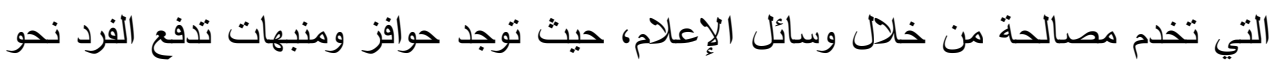

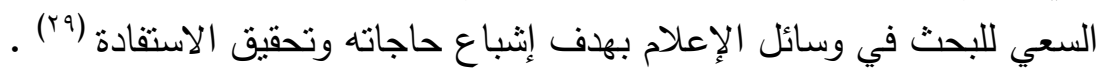

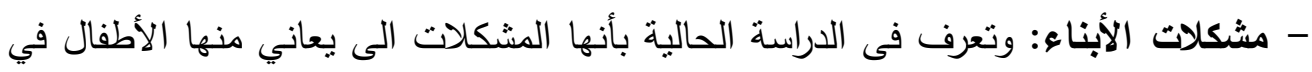

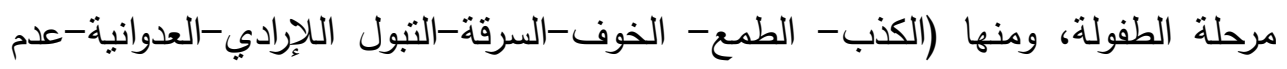

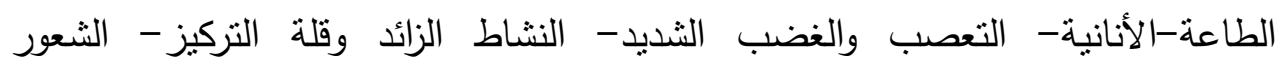
بالنقص- الإنطواء -.....) .

- مواقع التواصل الإجتماعي : هي خدمات توجد على شبكة الويب "

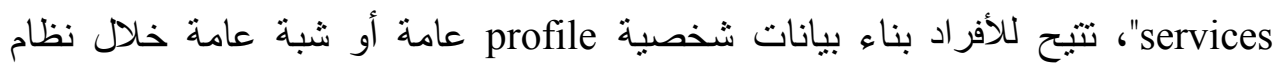

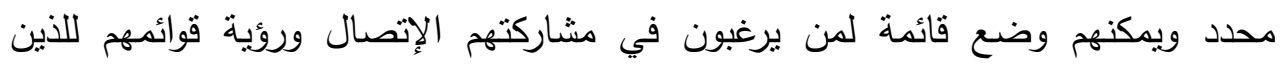

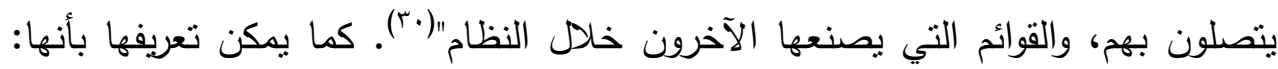

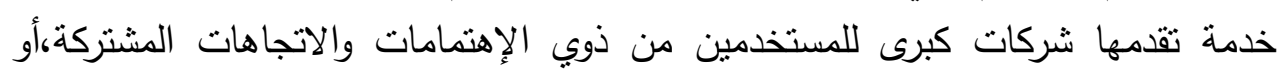

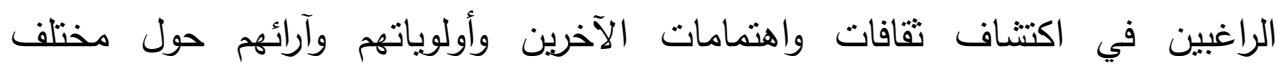
الموضوعات والقضايا، وتتيح لهم العديد من المزايا التقنية مثل المحادثة وإرسال الرسائل والثيان 
والمناقثات الجماعية وتبادل المراسلات والملفات والتدوين، ومن أشهرها مواقع " الفيس

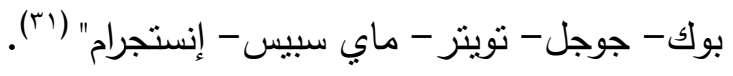
- الإثباعات: ويقصد بها في الدراسة الحالية، الاستفادة التي تحققت للوالدين نتيجة

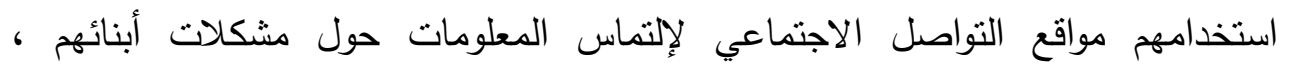
ومساهنها في حل هذه المشكلات . الاراسات السابقة : n

تتعدد وتتداخل الدراسات السابقة المرتبطة بموضوع الدراسة الحالية، ما بين دراسات

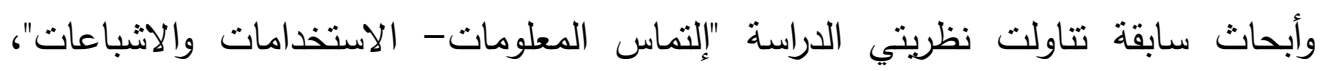
ودراسات تتاولت "مواقع التواصل الإجتماعي"، وعلى هدا سوف تقتصر الباحثة في عرضها

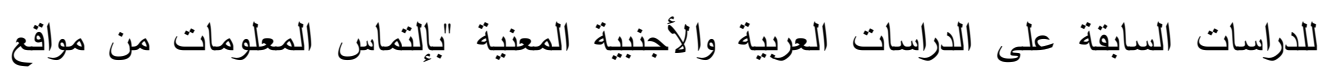

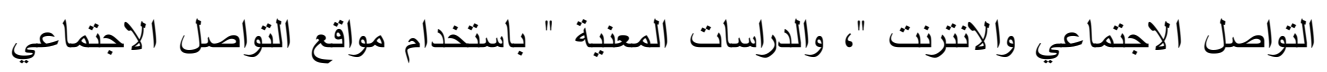
والإنترنت والاشباعات المتحققة". وعلى هدا تعرض الباحثة الدراسات السابقة من خلال المحورين الرئيسيين التاليين: المحور الأول: الدراسات السابقة العربية والأجنبية المعنية بإلتماس المعلومات من مواقع التواصل الاجتماعي وشبكة الإنترنت:

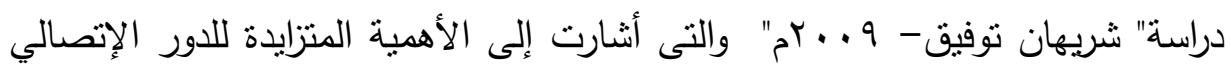

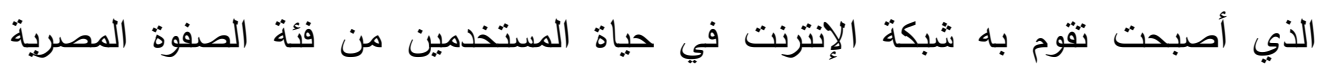

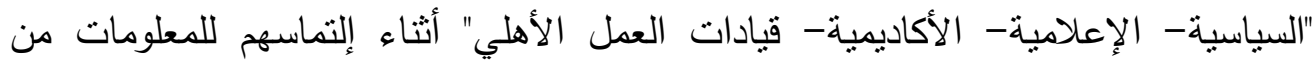

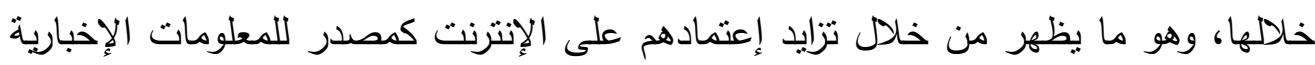

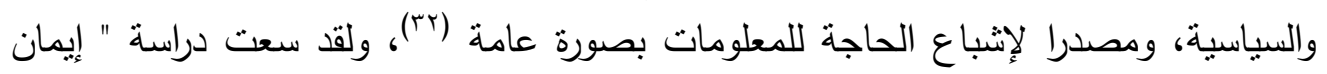

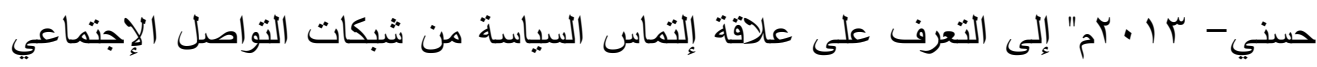

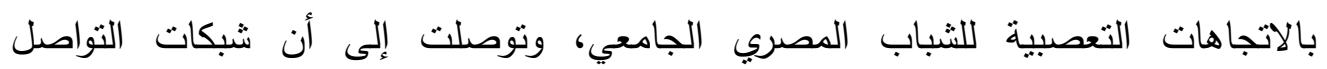

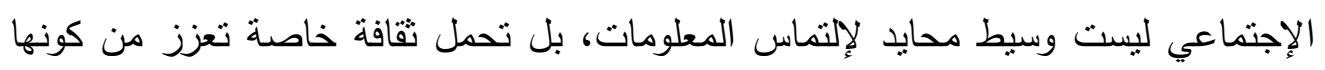

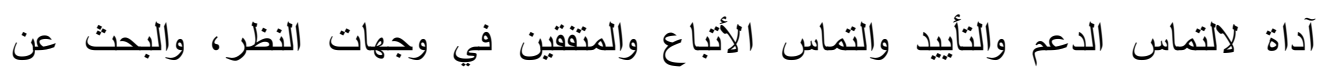

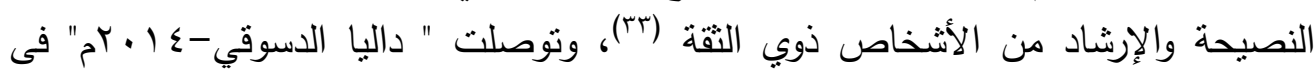
دراستها: إلى أن حوالي (YYI\%) من عينة الدراسة " من دارسي الإعلام التربوي بالجامعات

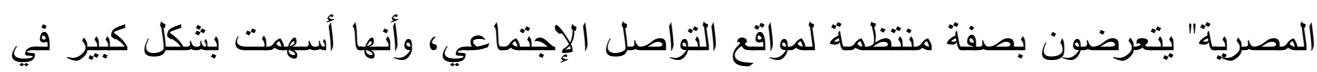

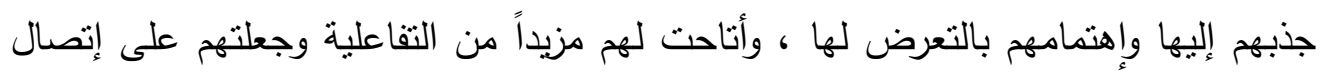


دائم ومباشر مع أصدقائهم وشبكة علاقاتهم الإجتماعية، وأنها أهم مصدر للمعلومات أثناء

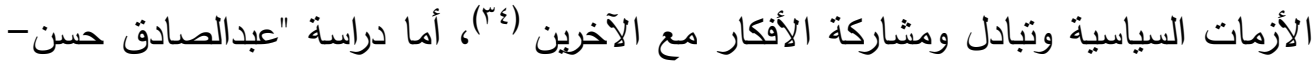

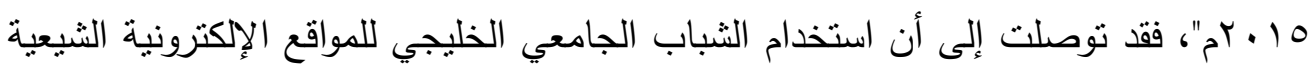

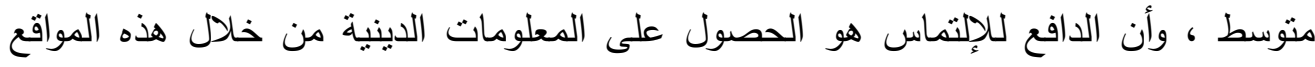

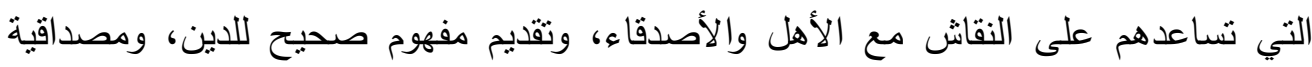

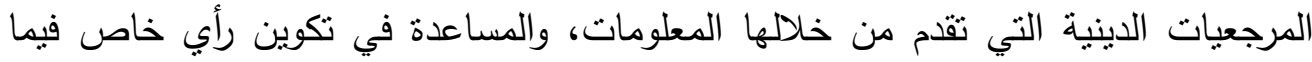

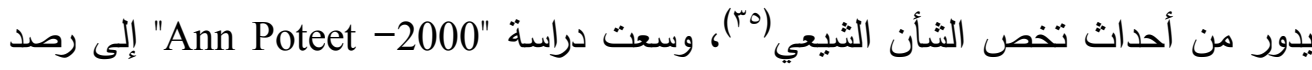
وتحليل سلوك الصحفيين في إلتماس المعلومات من المصادر الإلكترونية والإنترنت والمصادر

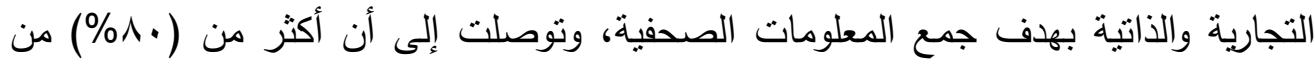

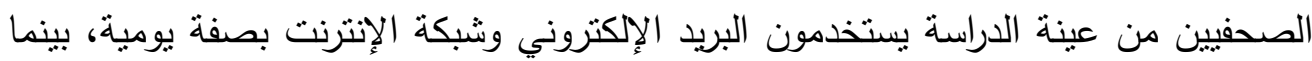

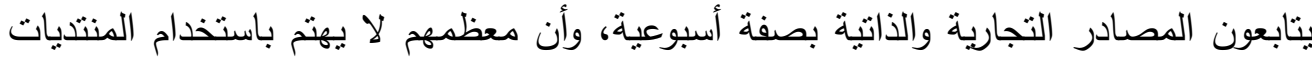

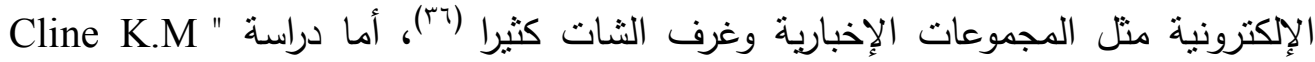

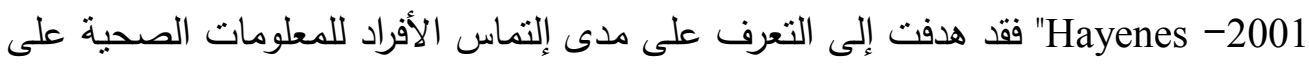

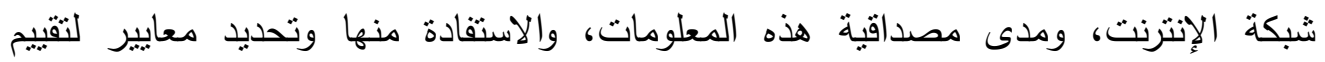

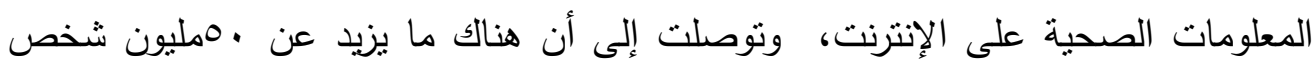

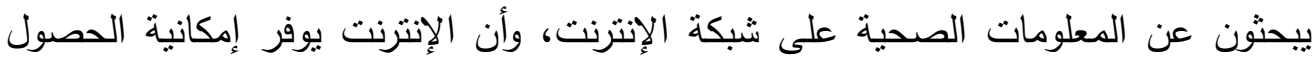

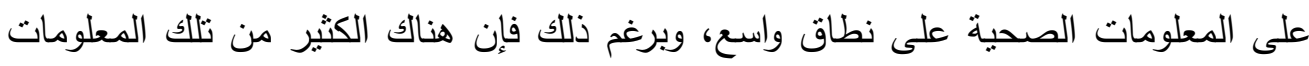

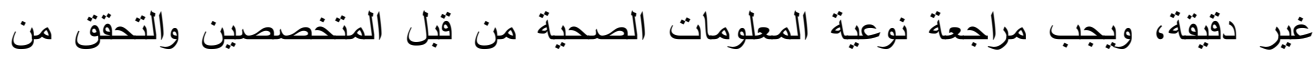

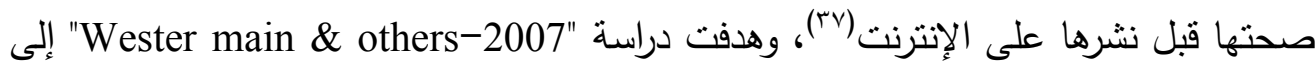

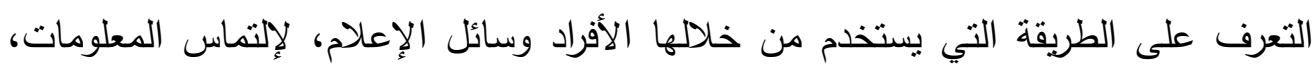

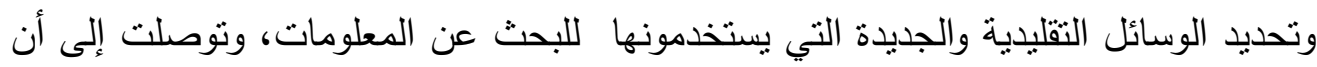

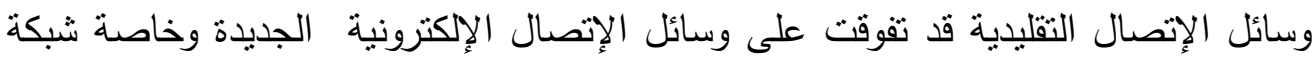

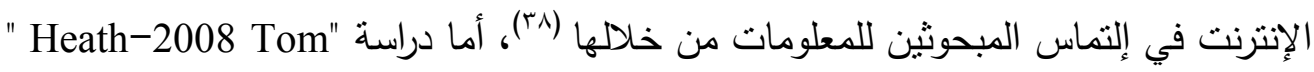

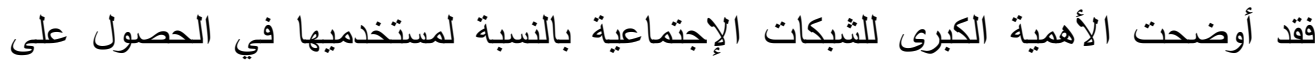

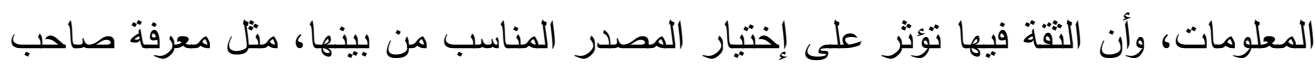

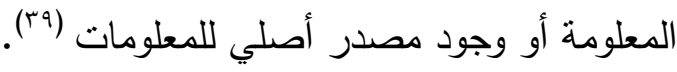
المحور الثاني: الدراسات السابقة العربية والاجنبية المعنية باستخدام مواقع التواصل

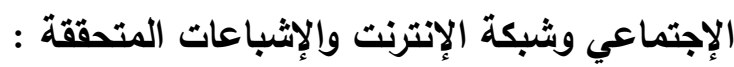

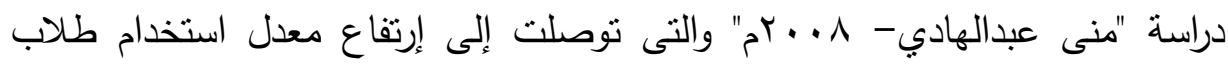

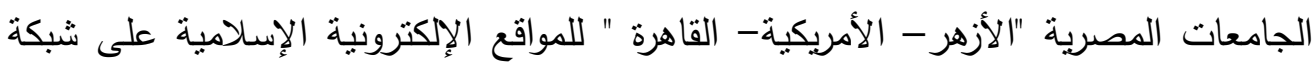




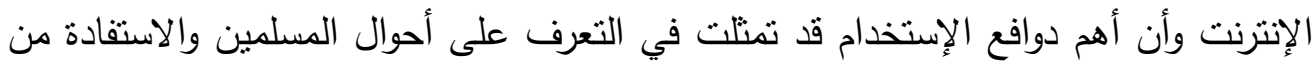

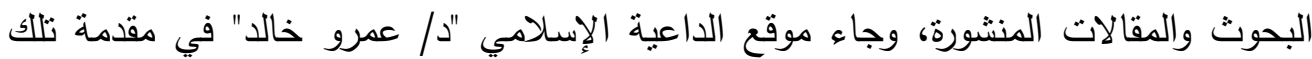

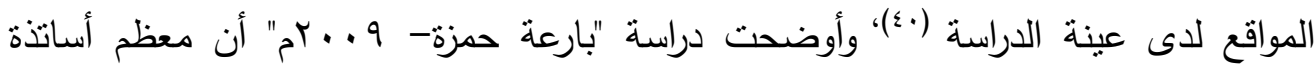

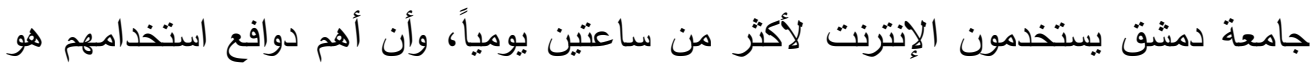

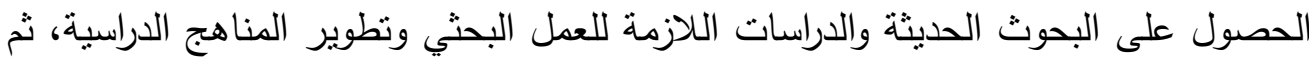

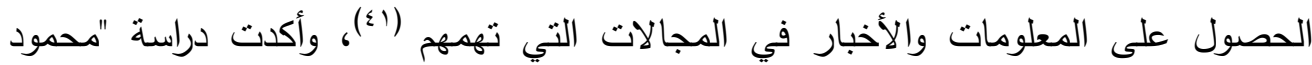
حمدى-9 . . بم" على وجود علاقة إرتباطية إيجابية بين استخدام الثباب من طلاب الجامعة

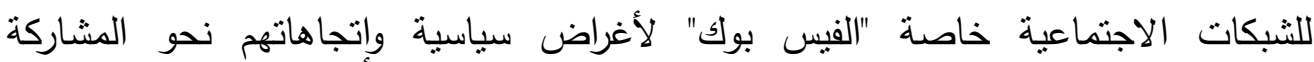
السياسية، كما أكد بعض المبحوثين أن "الفيس بوك" بيساعدهم على متابعة الأحداث الجارية

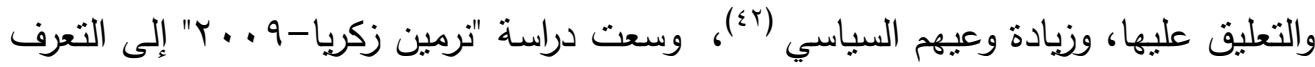

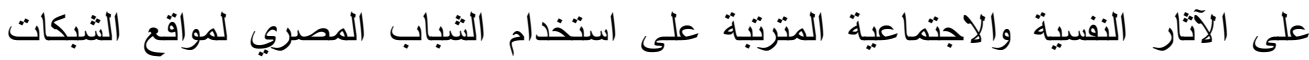

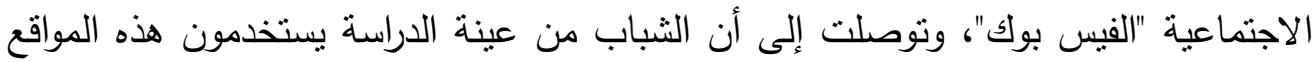
للتعرف على الأصدقاء الجدد وإقامة صداقات معهم، والإبقاء على العلاقات التهات بين الأصدقاء

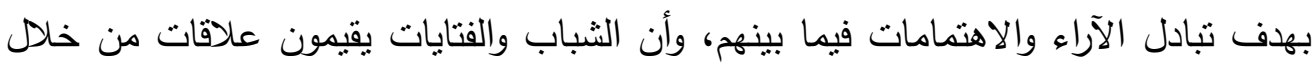

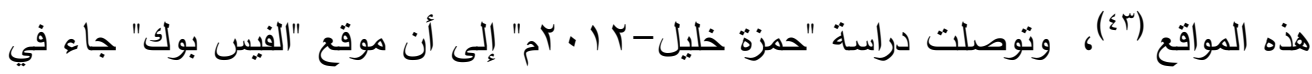
مقدمة مواقع الثبكات الإجتماعية إستخداماً بين الثباب الجامعي من عينة الدراسة للمشاركة

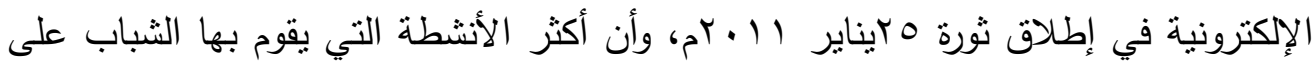

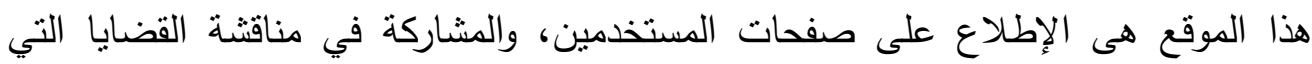

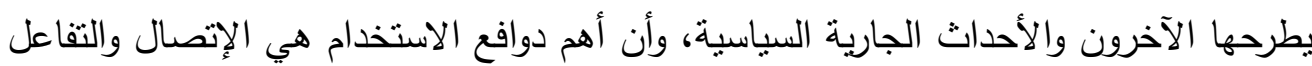

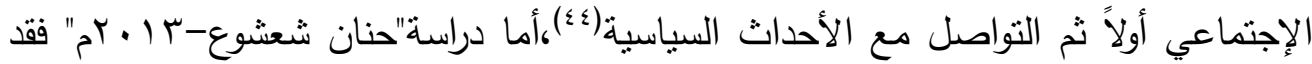

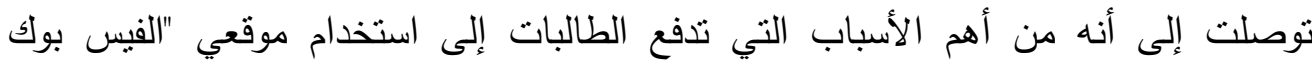

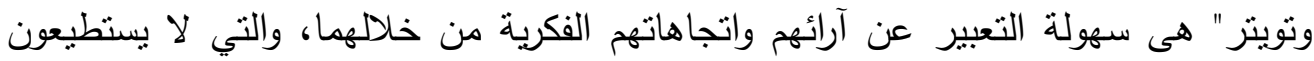

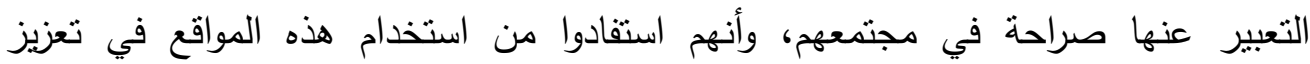
صداقاتهم القديمة، وإقامة صداقات جديدة والتواصل مع أقاربهم في الأماكن البعيدة، وأن التهات

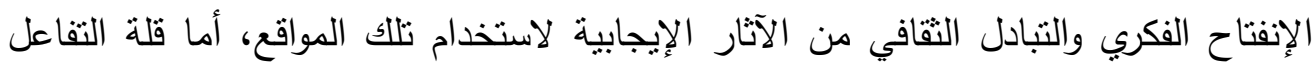

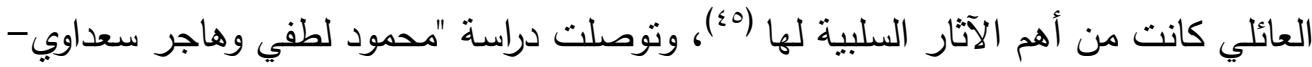

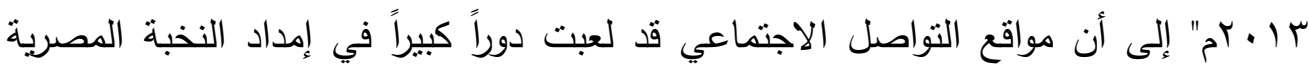

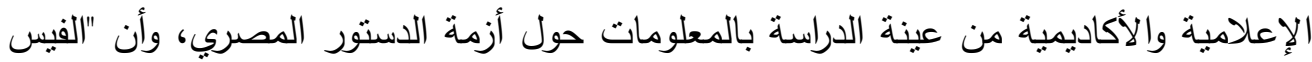
بوك ثم نويتز" قد جاءا في مقدمة تلك المواقع، وأن أهم أسباب ودوافع إستخدام عينة الدراسة الإنة 
لهده المواقع ،هي أنها مصدراً هاماً للمعلومات عن القضايا المختلفة، وإمكانية النقاش وتبادل

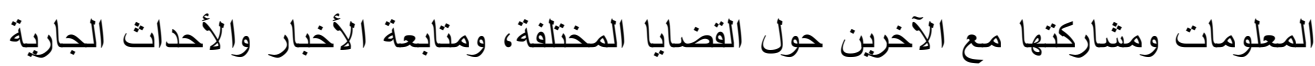

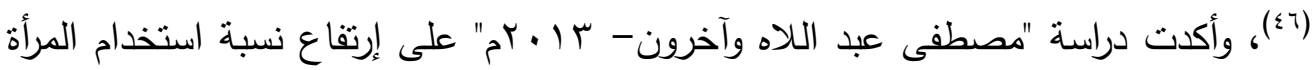

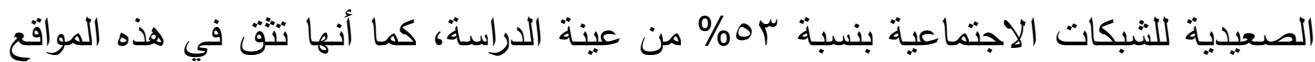

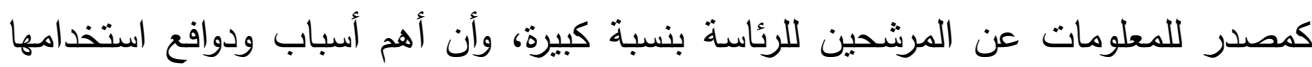

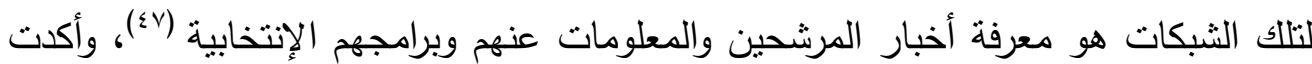

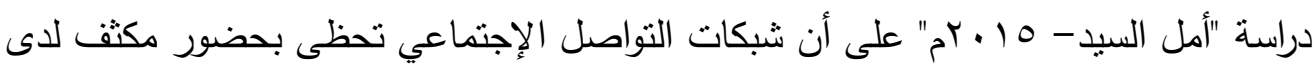
القائمين بالإتصال في الصفحات المتخصصة من عينة الدراسة على المستيكات المستوبين المهني

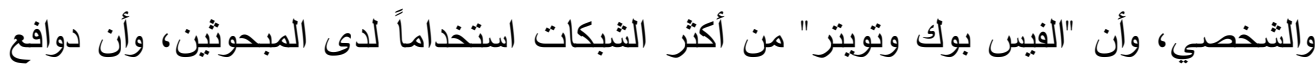

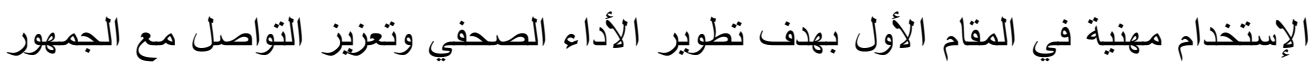

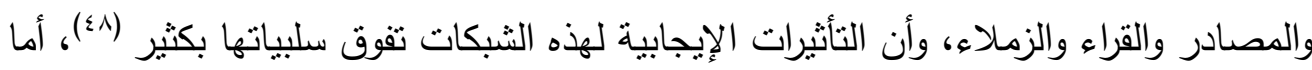
دراسة "سلمى إبراهيم- 0 ـ ـrم" فقد أوضحت أن موقعي "الفيس بوك وتويتر" قد إحتلا المراتب

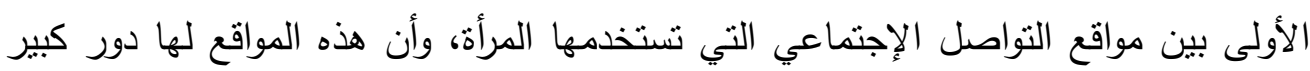

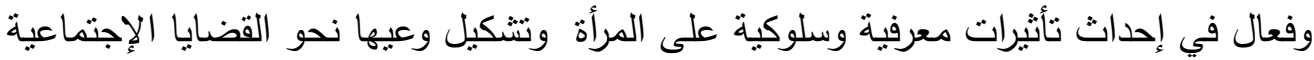

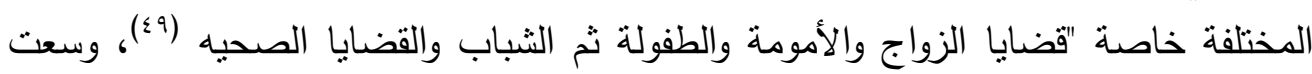

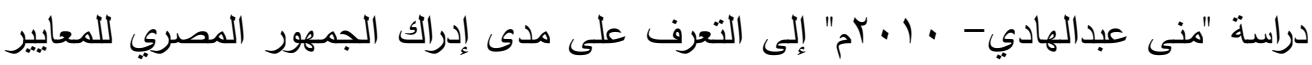

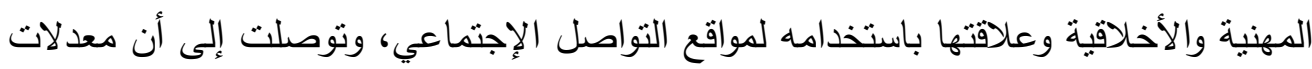

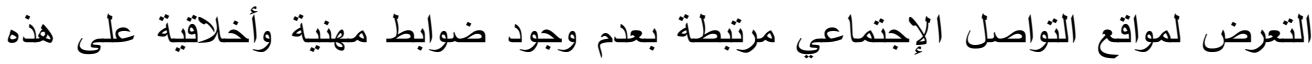

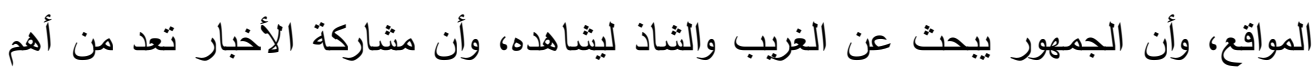

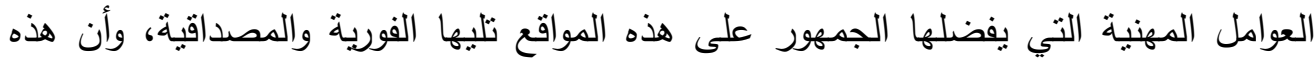

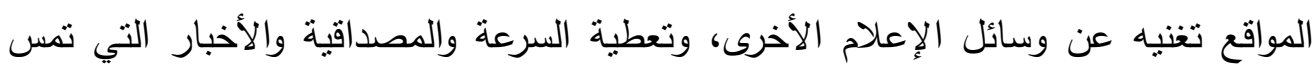

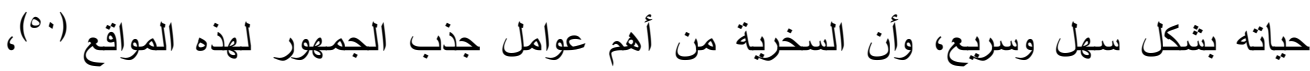

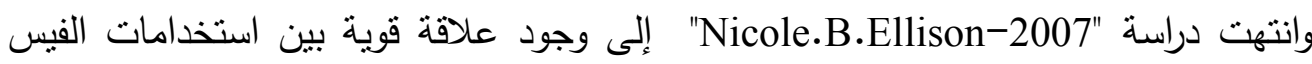
بوك وشعبية موقعة على الإنترنت، وأنه يوفر منافع كبيرة للمستخدمين خاصة الذين يعانون

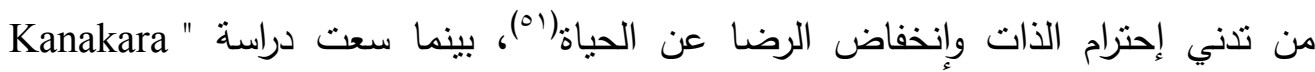

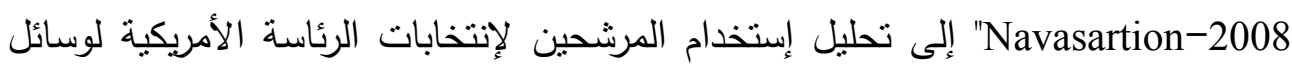

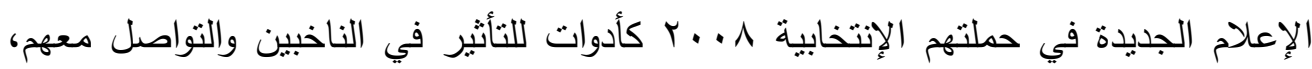
وتوصلت إلى أن النواصل الإكتروني مع الجمهور قد وفر كماً كبيراً من المعلومات المتداولة الإنية

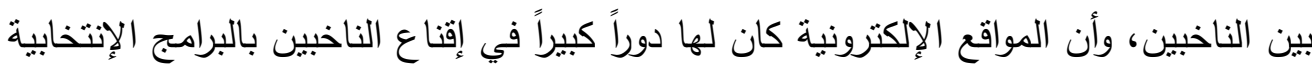




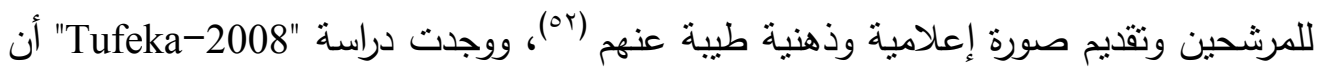
أكثر من 10\% من عينة الدراسة من الثباب الجامعي تستخدم مواقع الثبكات الإجتماعية

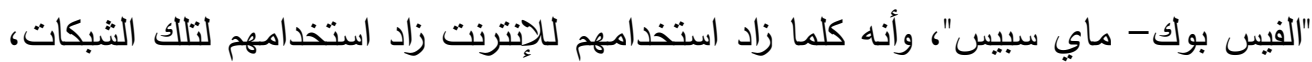

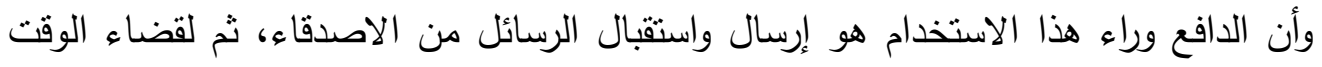

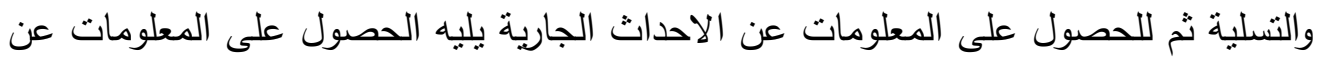

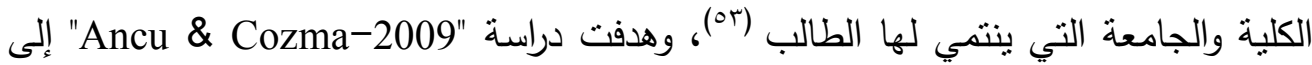

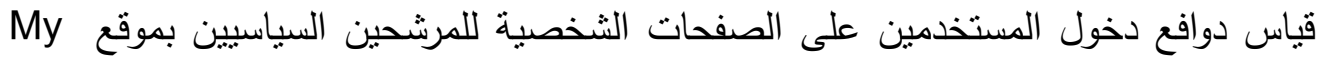

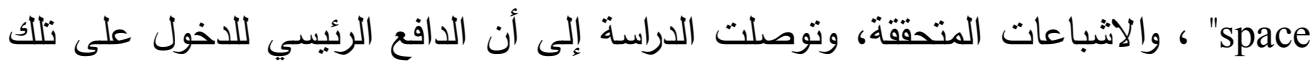

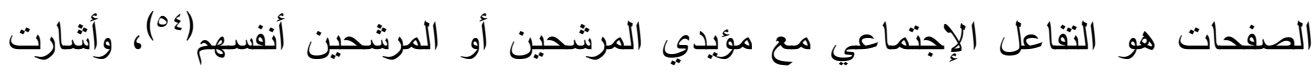
دراسة "Kathleen Sara Alpiza- 2010" إلى إرتفاع نسبة استخدام المراهقين لوسائل الإعلام الجديدة في حياتهم اليومية بحوالى 9 9\% من عينة الدراسة، وأن الدافع لهذا الاستخدام

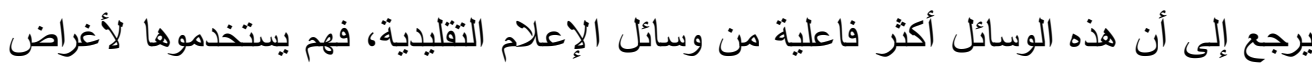

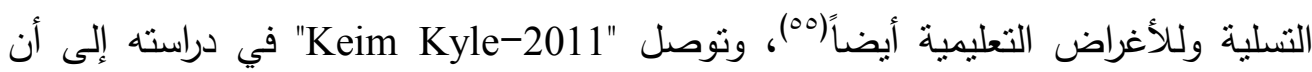
الصحفيين يتابعون نخبة المجتمع وأصحاب السلطة والقوة والنفوذ على شبكات التواصل

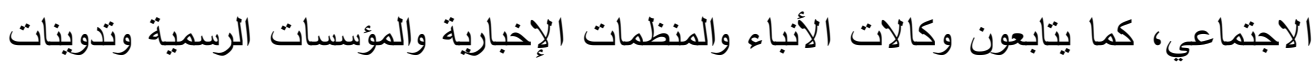

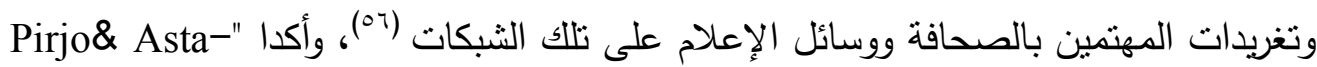

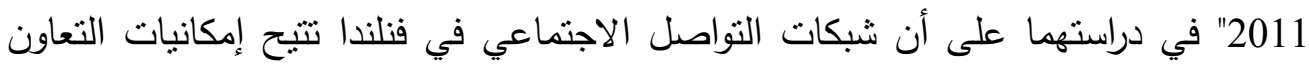

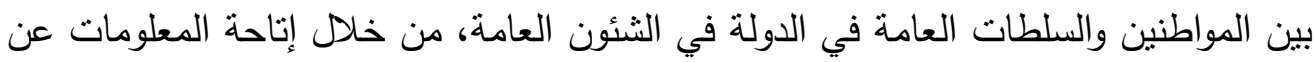
هيئات وسياسات الحكومة وتدعيم النقاش العام وخلق فهم مشترك بين المواطنيين ومؤسسات

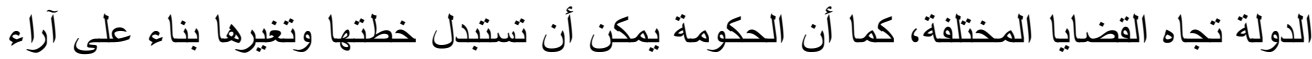

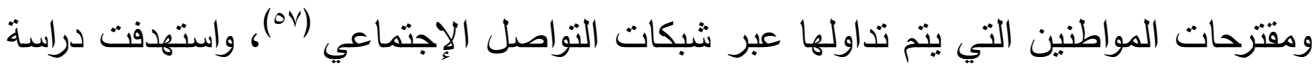

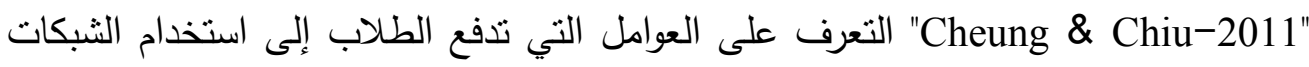

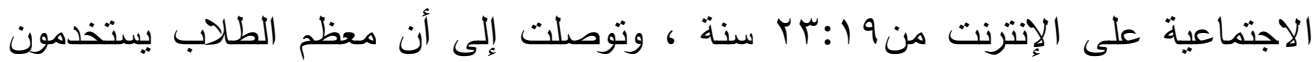

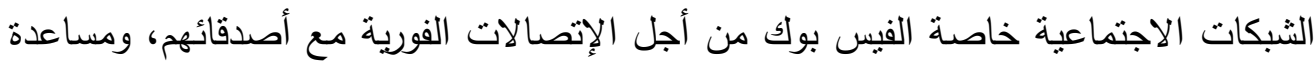

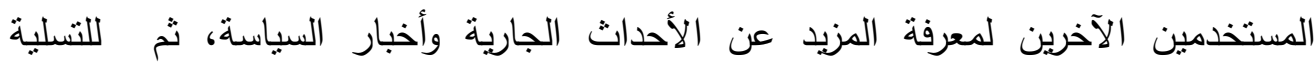
والتزفية(0)، بينما سعت دراسة" 2012-Monica Ancu" إلى التعرف على استخدامات كبار السن في عمر •0 عاماً فأكثر" للفيس بوك"، وتوصلت إلى أن التسلية والترفيه وممارسة

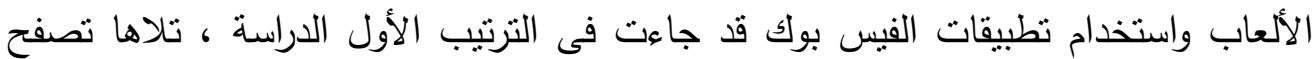

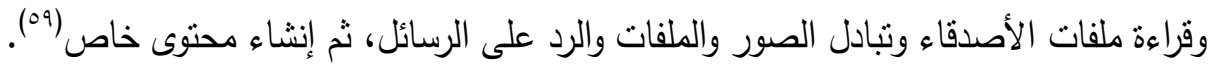




\section{تعليق عام على الارلسات السابقة :}

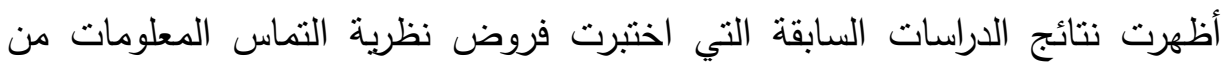

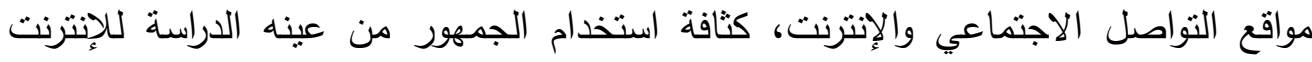

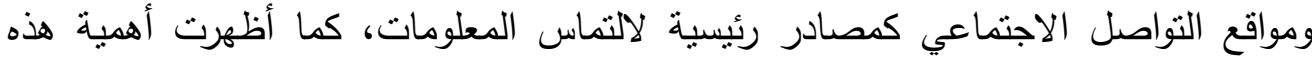
المواقع ومميزاتها في التواصل مع الآخرين ونشر المعلومات منل دراسة " شريهان توفيق

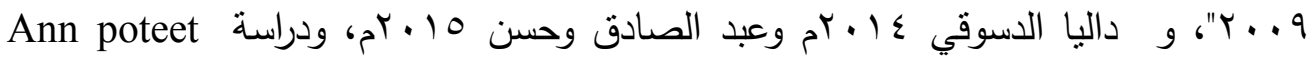
2008. السابقة على التأثثرات الإيجابية لالتماس المعلومات من مواقع التواصل الاجتماعي عدا دراسة

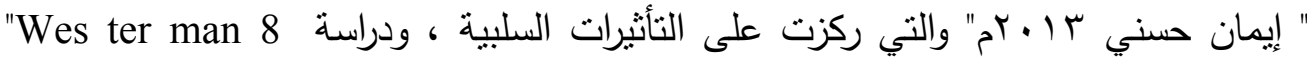

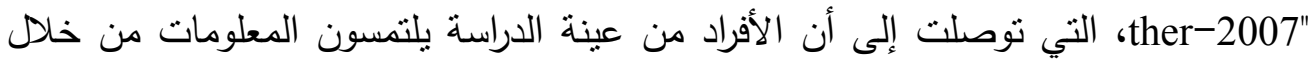
وسائل الإعلام التقليدية أكثر من وسائل الإعلام الجديدة. غير الإد من أن معظم الدراسات السابقة

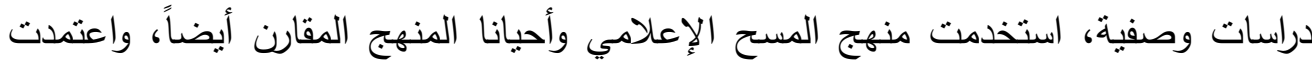

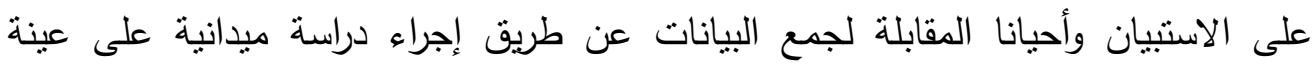

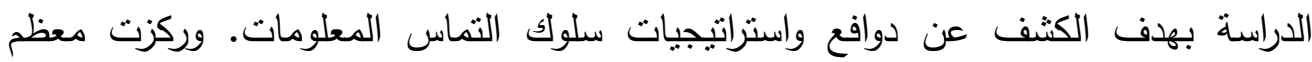
الدراسات السابقة على الهرف من التماس المعلومات، وسلوك المبحوثين في الالتماس خاصة

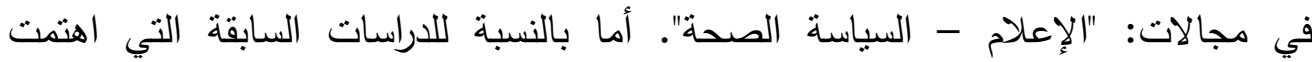

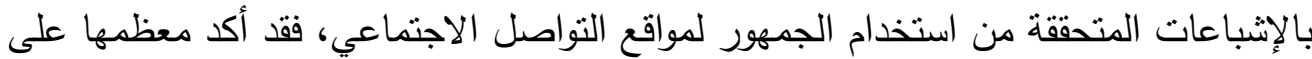

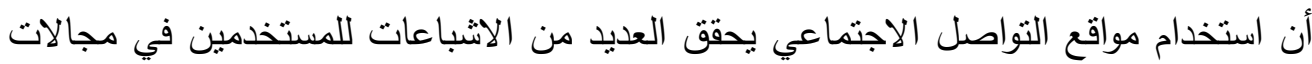

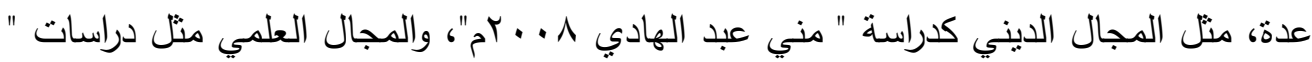

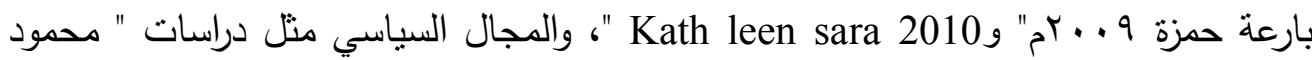

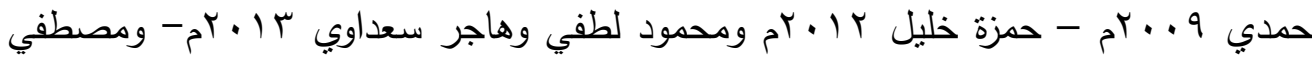

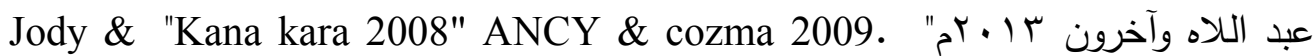

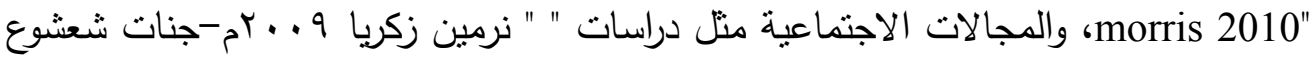

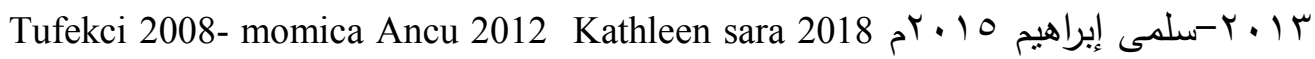

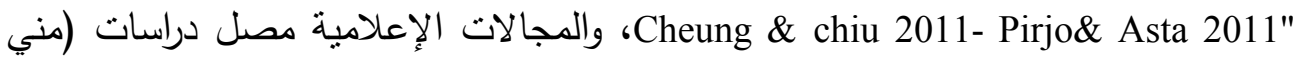

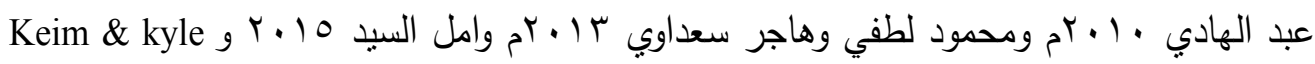
200 والمجالات النفسية مثل دراسة " نرمين زكريا 9 . . بح" ودراسة "Nicole.B.Ell is on 2007".

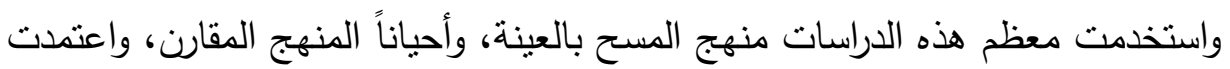

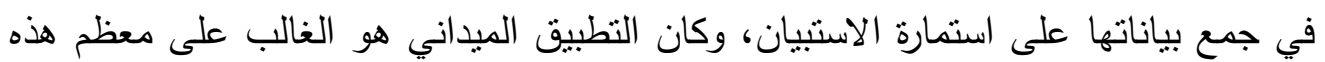
الدراسات. وأكدت نتائج الدراسات السابقة على وجود اختلافات في استخدامات الجمهور 
لمواقع التواصل الاجتماعي والإنترنت، وفي الاثباعات المحققة. ولقد استفادت الباحثة من

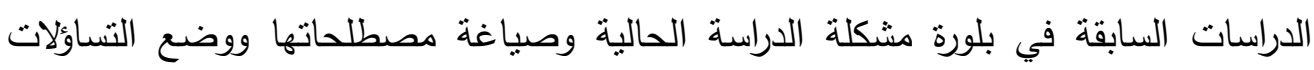
والفروض،وتصميم استمارة استبيان،ومقارنة نتائج هذه الدراسات بنتائج الدراسة الحالية. وأهم

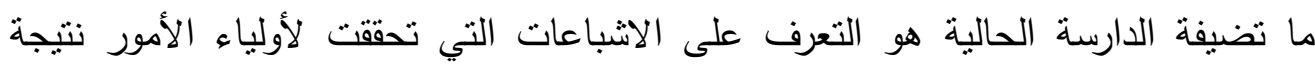

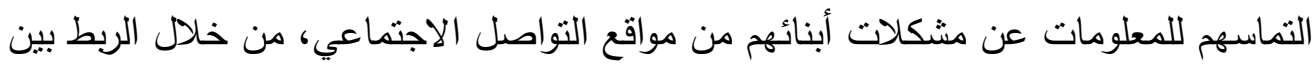

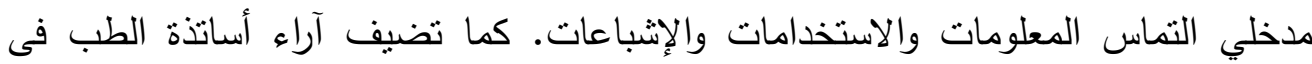

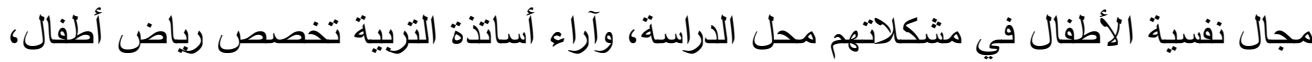

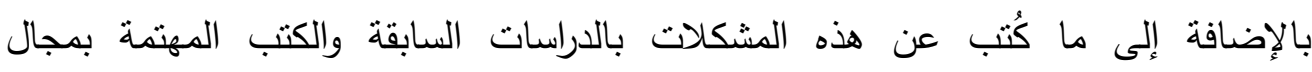
مشكلات الأطفال. أهداف الاراسةة:

تهدف الدراسة الحالية إلى تحقيق هدف رئيسي، وهو : "الكثف عن مدى إلتماس الوالدين للمعلومات حول مشكلات أبنائهم من مواقع التواصل الإجتماعي، ودوافع واستراتيجيات

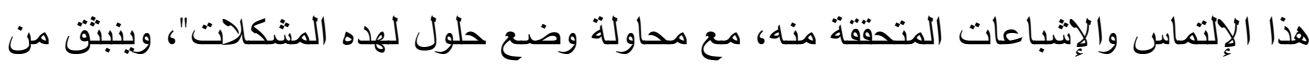
هذا الهدف الرئيسي الأهداف الفرعية التالية:1-قياس معدل إستخدام الوالدين للإنترنت ومواقع التواصل الإجتماعى .

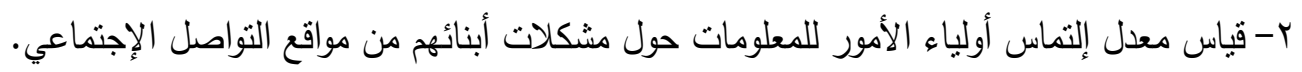

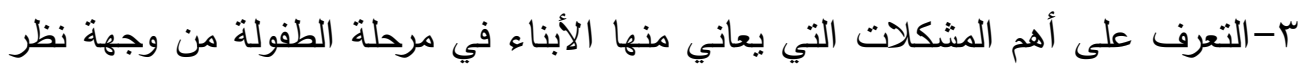
أولياء الأمور.

ع-الكثف عن دوافع التماس أولياء الأمور للمعلومات عن مشكلات أبنائهم من مواقع

$$
\text { التواصل الإجتماعي. }
$$

ه-التعرف على أهم مواقع التواصل الإجتماعي التي يستخدمها أولياء الأمور لإلتماس المعلومات حول مشكلات أبنائهم. 7-الكثف عن مدى ثقة أولياء في مواقع التواصل الإجتماعي كمصدر للمعلومات عن مشكلات أبنائهم. V-الكثف عن استراتيجيات أولياء الأمور في إلتماس المعلومات عن مشكلات أبنائهم من مواقع التواصل الإجتماعي. 1-التعرف على مدى استفادة أولياء الأمور من مواقع التواصل الإنماءت الإتماعي كمصدر للمعلومات عن مشكلات أبنائهم. 
9-الكثف عن الإشباعات المتحققة لأولياء الأمور من استخدام مواقع التواصل الإجتماعي لإلتماس المعلومات عن مشكلات أبنائهم.

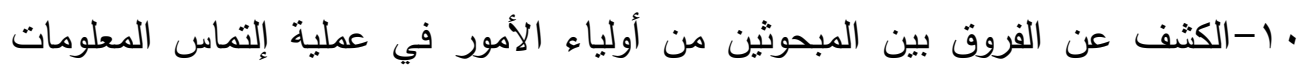

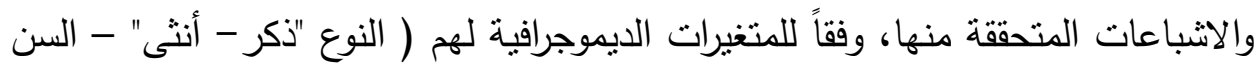

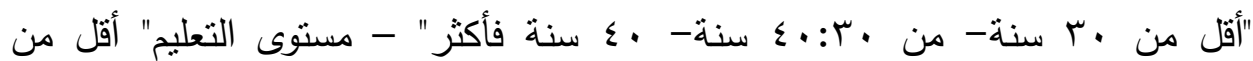

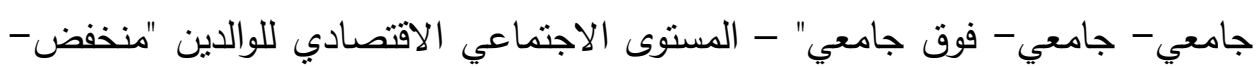
متوسط -مرتفع ").

1ا-وضع حلول لمشكلات الأطفال من وجهة نظر الأطباء والمتخصصين في مجال الطفولة قد تساعد الوالدين والمربين. تساوْلات الادراسة:

تسعى الدراسة الحالية إلى الإجابة على التساؤل الرئيسي التالي: ما مدى إلتماس أولياء

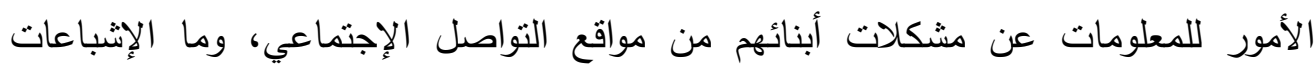

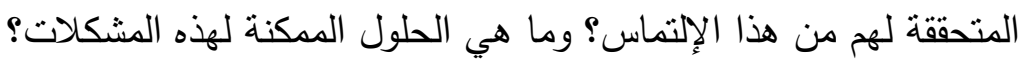

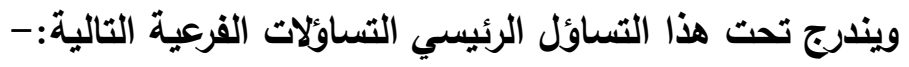

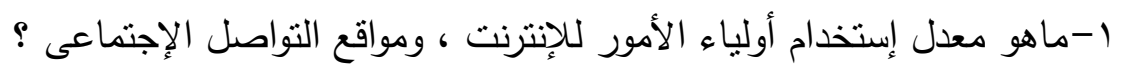

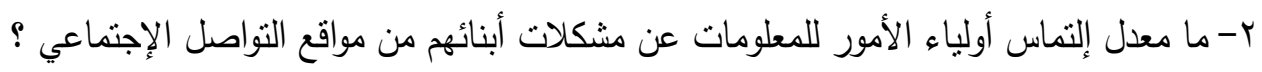

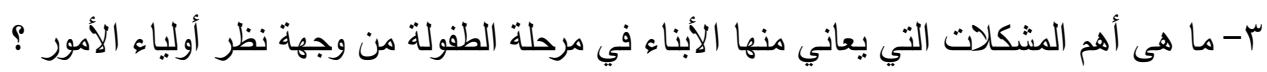

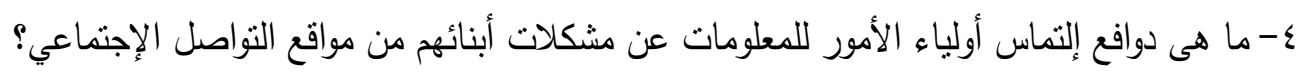

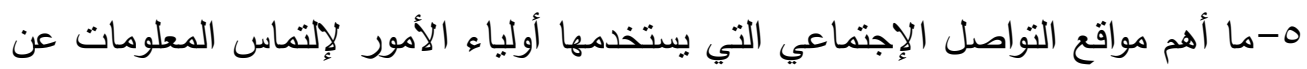

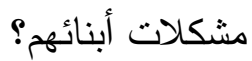
4-إلى أى مدى يثق أولياءالأمور في مواقع التواصل الإجتماعي كمصدر للمعلومات عن مشكلات أبنائهر? V-ما هى استراتيجيات أولياء الأمور في إلتماس المعلومات عن مشكلات أبنائهم من مواقع

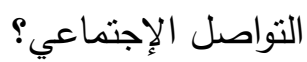
^-ما مدى استفادة أولياءالأمورمن مواقع التواصل الإجتماعي كمصدرللمعلومات عن الإن مشكلات أبنائهم؟ مان 9-ما هى الإشباعات المتحققة لأولياء الأمور من استخدامهم لمواقع التواصل الإجتماعي

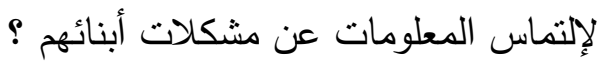

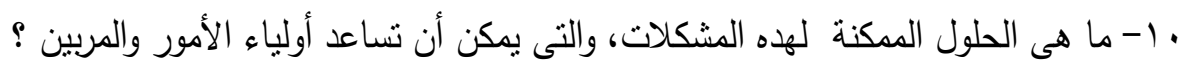




\section{فروض الاراسة:}

تسعى الدراسة الحالية إلى اختبار صحة الفرض الرئيسي التالي: " توجد علاقة إيجابية

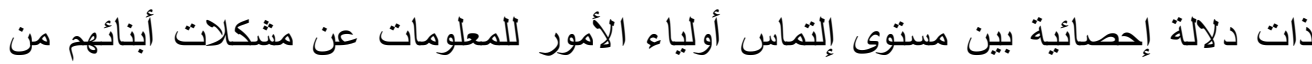

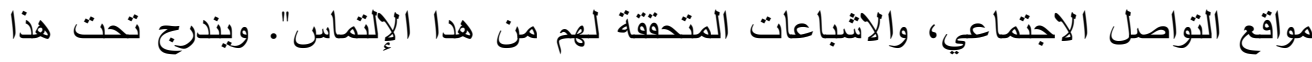
الفرض الرئيسي الفروض الفرعية التالية: الفرض الأول : نوجد علاقة إرتباطية موجبة ودالة إحصائياً بين مستوى استخدام أولياء الأمور للإنترنت ومستوى استخدامهم لمواقع التواصل الإجتماعى .

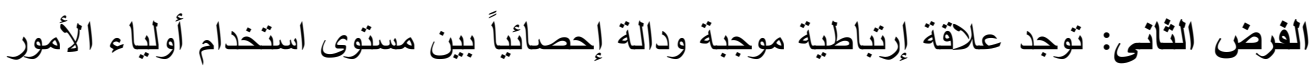
لمواقع التواصل الاجتماعي ومستوى إلتماسهم للمعلومات عن مشكلات أبنائهم

$$
\text { من خلالها. }
$$

الفرض الثالث: توجد علاقة إرتباطية موجبة ودالة إحصائيا بين دوافع إلتماس أولياء الأمور

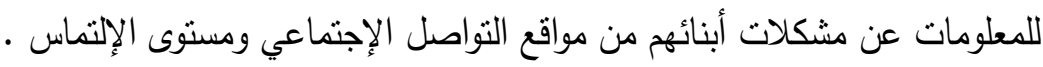

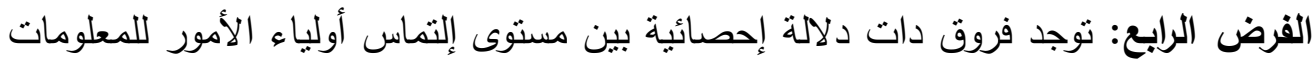

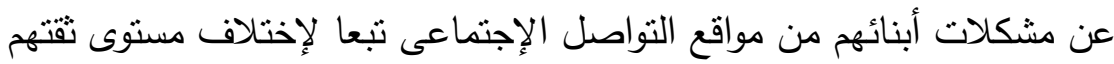

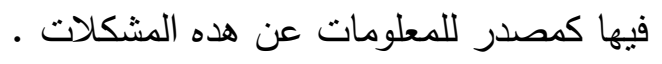

الفرض الخامس: توجد فروق دات دلالة إحصائية بين مستوى الإثباعات المتحققة لأولياء

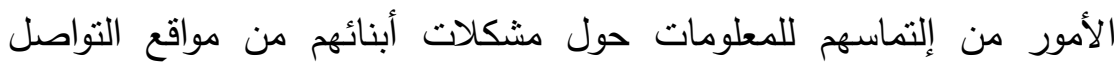

$$
\text { الإجتماعى تبعا لإختلاف مستوي الإلتماس. }
$$

الفرض السادس: توجد علاقة ارتباطية موجبة ودالة إحصائيا بين دوافع التماس أولياء الأمور

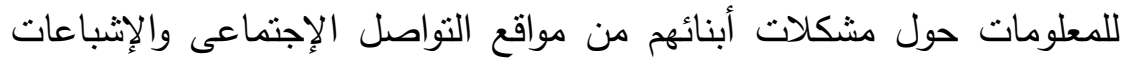

$$
\text { المتحققة لهم • }
$$

الفرض السابع: توجد فروق دات دلالة إحصائية بين متوسطات درجات المبحوثين على

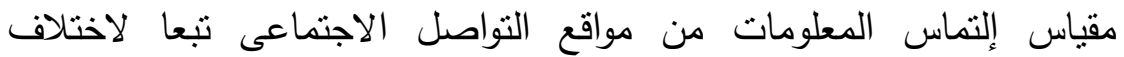

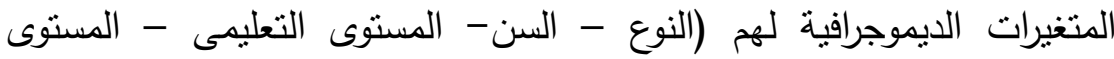

$$
\text { الاجتماعى الاقتصادى - مكان الإقامة). }
$$

الفرض الثامن: توجد فروق دات دلالة إحصائية بين متوسطات درجات المبحوثين على الألى الأل

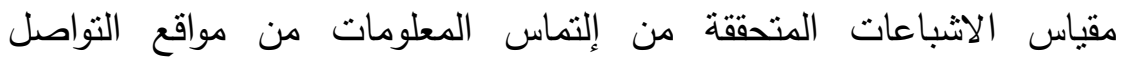

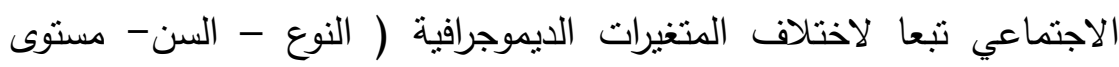

$$
\text { التعليم - المستوى الاجتماعي الاقتصادي- مكان الإقامة). }
$$


الإطار المنهجي والإجرائي للادراسة: 1- نوع الاراسة وإلمنهج المستخدم:

تتتمي هذه الدراسة إلى الدراسات الوصفية Descriptive studies، وتعتمد على منهج

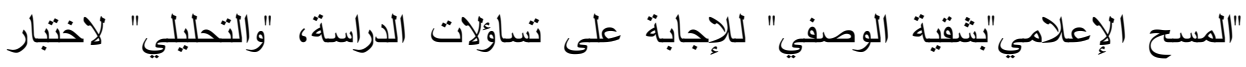

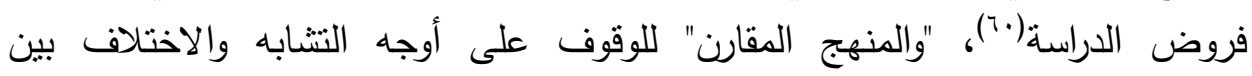

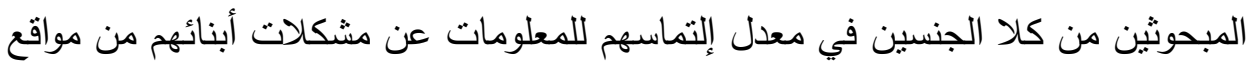

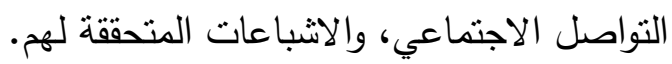

\section{r - مجتمع وعينة الاراسة:}

يتمثل مجتمع الدراسة الحالية في عينة عشوائية غير منتظمة من أولياء الأمور ممن لهم

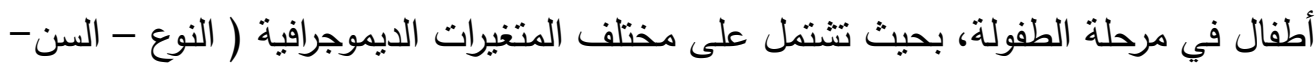

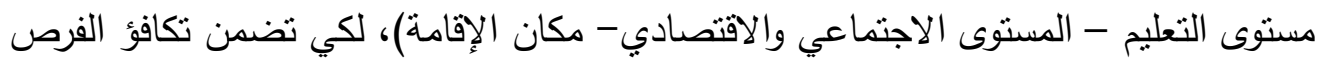

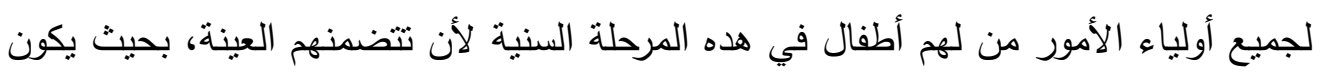

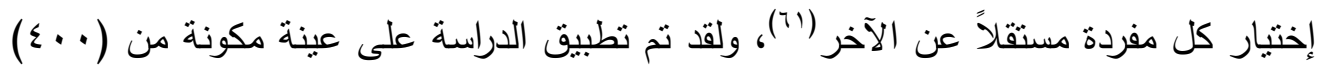
مفردة من محافظتي الغربية والقاهر ، من مستخدمي مواقع التواصل الإجتماعي.

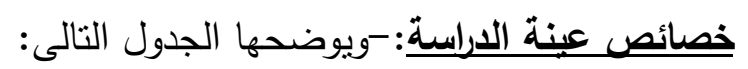

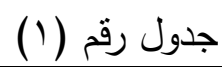

\begin{tabular}{|c|c|c|c|}
\hline النسبة & التكرار & | المجموعات & الخصائص \\
\hline$\leq 7.0$ & 114 & ذكور & \multirow{2}{*}{ النوع } \\
\hline or.o & $r ! \varepsilon$ & إناث & \\
\hline$r . . r$. & 1) & أقل من •r سنه & \multirow{3}{*}{ السن } \\
\hline$\varepsilon 0 . r$. & $|1|$ & من .r : :- & \\
\hline$r \leqslant .0$. & 1rk & •ـ سنة فأكثر & \\
\hline$r \ldots .$. & $\wedge \varepsilon$ & أقل من جامعى & \multirow{3}{*}{ المستوى التعليمى } \\
\hline$\leq 0 . \ldots$ & $1 \wedge$. & جامعى & \\
\hline$r \leqslant \ldots$ & 4r & أعلى من جامعى & \\
\hline ru.vo & 100 & مرتفع & \multirow{3}{*}{ الاقتصادي الاجتماعي } \\
\hline$\varepsilon 0 . r_{0}$ & 111 & متوسط & \\
\hline $17 . .$. & $T \varepsilon$ & منخفض & \\
\hline$\% 1 .$. & $\varepsilon \ldots$ & & المجموع \\
\hline
\end{tabular}


الحدود الموضوعية للاراسة: تقتصر الدراسة الحالية على مشكلات الأطفال في "مرحلة

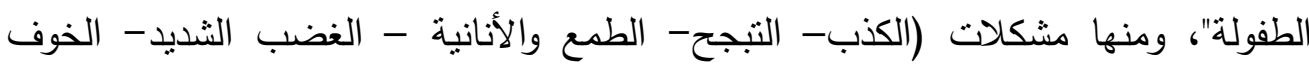
الثديد- السرقة- التبول اللاإرادي- العدوانية- عدم الطاعة والاعتراض الدائم - النشاط الزائد

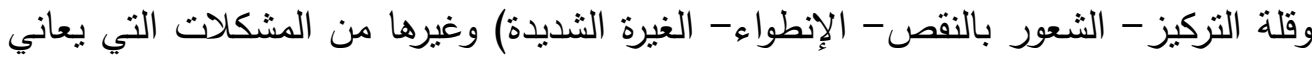

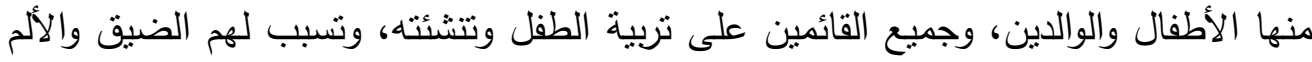

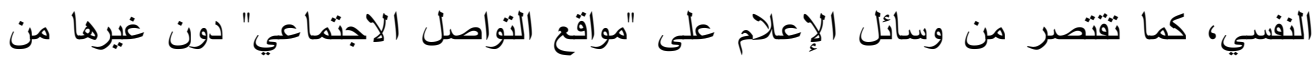

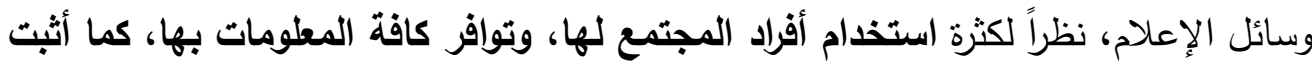

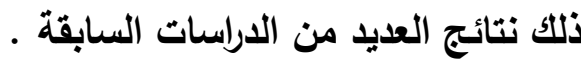

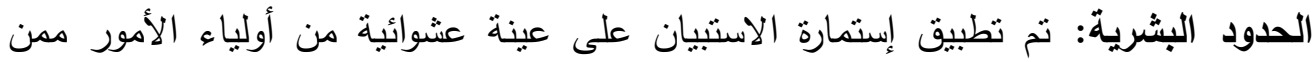

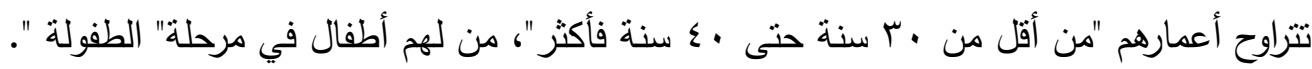

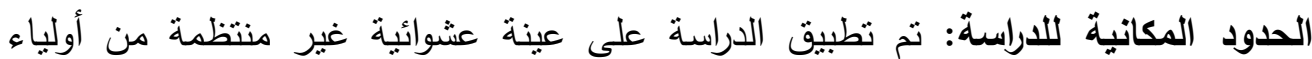
الأمور في محافظتي "الغربية والقاهرة".

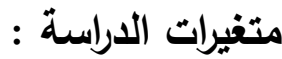
أ. المتغير المستقل: ويتمثل في: "مدى إلتماس الوالدين للمعلومات حول مشكلات أبنائهر من مواقع التواصل الاجتماعي".

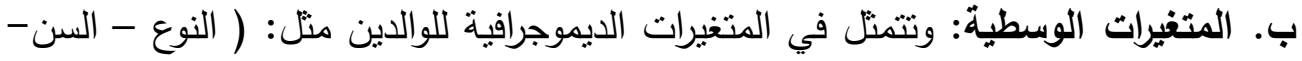

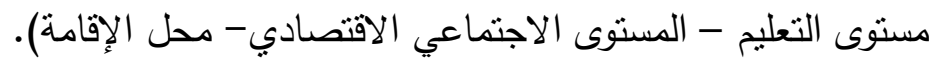

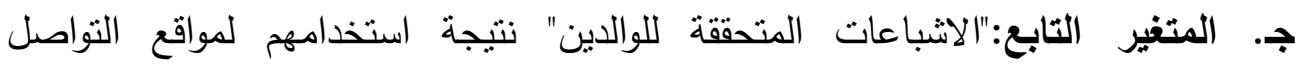

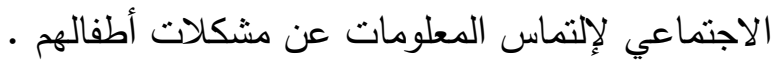

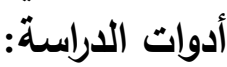

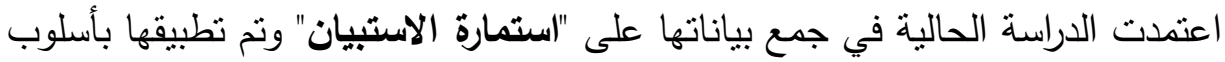

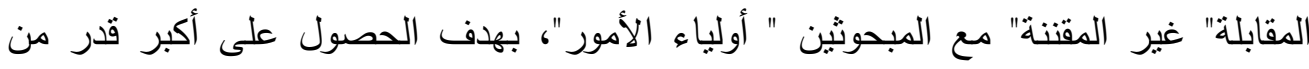

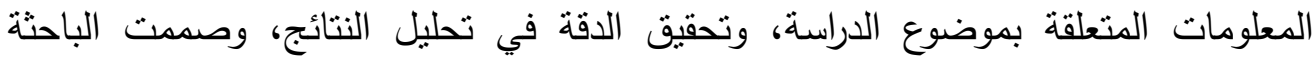

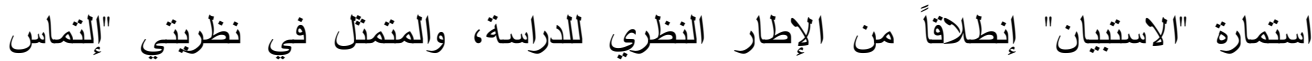

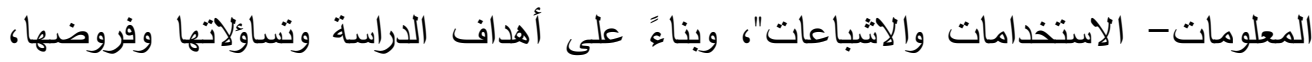

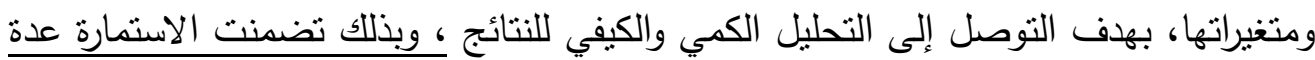
محاور ، من أهمها:

أولاً: مدى استخدام الوالدين للإنترنت ومواقع التواصل الاجتماعي، وتفضيلات تللك المواقع.

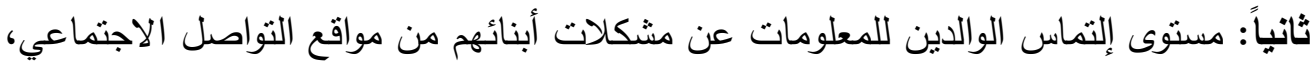

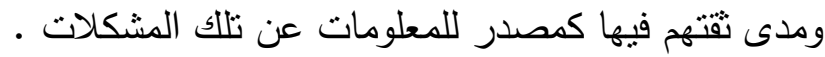


ثالثاً: دوافع إلتماس الوالدين للمعلومات عن مشكلات أبنائهم من هذه المواقع. رابعاً: أهم مشكلات الأبناء في مرحلة الطفولة.

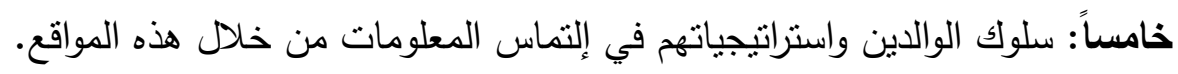

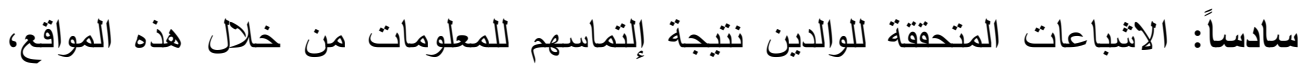
والفروق بينهم بسبب اختلاف المتغيرات الديموجرافية.

الصدق والثبات لاستمارة الاستبيان :

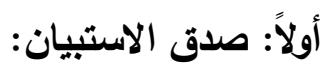

يقصد بصدق الآداه صحتها في قياس ما تدعى أنها تقيسه، والاستبيان الصادق هو الانيان الدى يقيس ما وضع لقياسه، وللتحقق من صدق الاستبيان إعتمدت الباحثة علي الطرق التالية

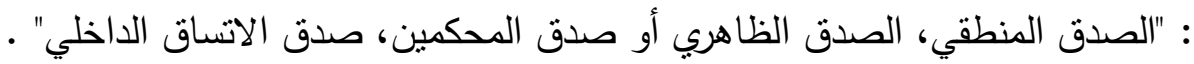
أ- الصدق المنطقي (صدق المحتوى): اعتمدت الباحثة فى بناء هذا الاستبيان واختبار

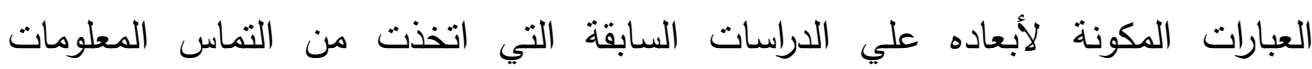
والإستخدامات والإثباعات ومشكلات الأطفال موضوعا لهاءواشتقت بعض عبات عاراته من

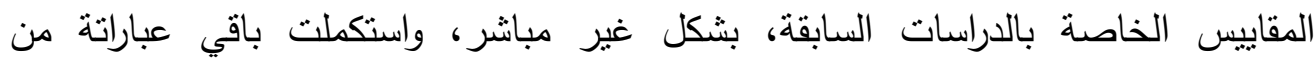

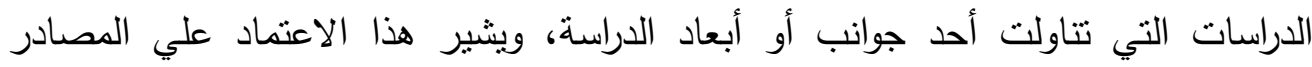
السابقة إلي تمتع الإستبيان بقدرمبول من الصدق المنطقي وأنه صالح للتطبيق. ب- الصدق الظاهري أو صدق المحكمين: نم عرض استمارة الإستبيان علي مجموعة من الإن

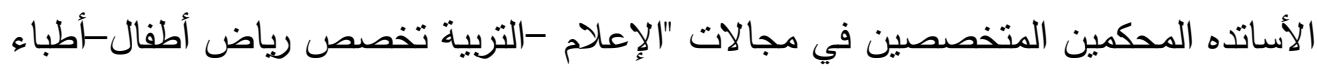
نفسية الأطفال " في الجامعات المصرية (")، وذلك بغرض دراسة محاور الإستمارة جيدا،

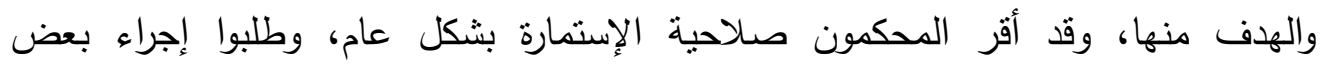
التعديلات، والتى نفدتها الباحثة فى ضوء الملاحظات التى أبدوها، وتم الإبقاء على المفردات

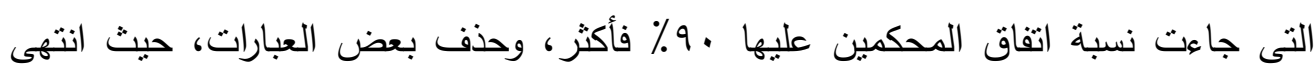
عدد نساؤلات الاستبيان إلى 10 سؤال بالإضافة إلى البيانات الثخصية والمتغيرات الديموجرافية. ج- صدق الاتساق الداخلي: تم حساب معاملات الإرتباط بين درجة كل بعد من أبعاد

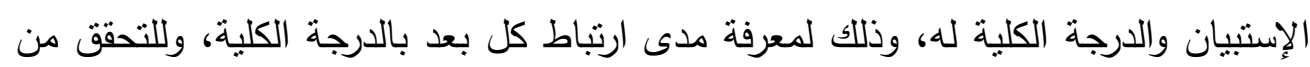
صدق الإستبيان، ويتضح ذلك من خلال الجدول التالى : الإنه ودنه 


\section{جدول (r)}

معاملات الارتباط بين الدرجة الكلية لكل بعد فرعى والدرجة الكلية للاستبيان

\begin{tabular}{|c|c|c|}
\hline 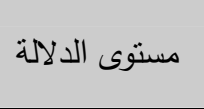 & 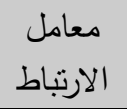 & 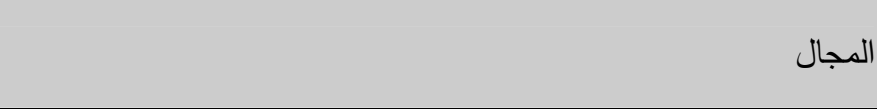 \\
\hline دالة عند ا •... &.$V Y r$ & بعد استخدام الإنترنت \\
\hline دالة عند ا ... & $.70 \mathrm{r}$ & بعد استخدام مواقع التواصل الاجتماعى \\
\hline دالة عند ا •.. &.$\vee \vee 9 \wedge$ & بعد التماس المعلومات عن مشكلات الأبناءمن مواقع التواصل الاجتماعى \\
\hline دالة عند ا ... & $\cdot . \Lambda 1 \mathrm{r}$ & بعد دوافع التماس المعلومات عن مشكلات الأبناء من مواقع التواصل الاجتماعى \\
\hline دالة عند ا +... &.$\wedge r r$ & بعد قياس مصداقية مضمون مواقع التواصل الاجتماعى \\
\hline دالة عند ا +... &..$\wedge 91$ & بعد الاشباعات المتحققة من استخدام مواقع التواصل الاجتماعى \\
\hline
\end{tabular}

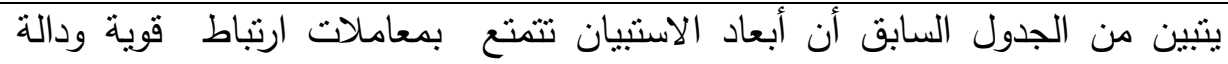

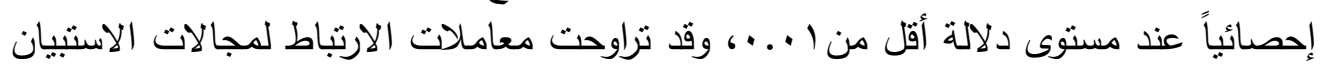

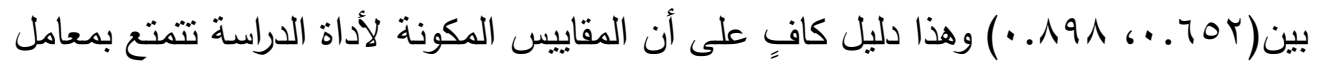
صدق عالي. ثانياً: ثبات الاستبيان: عالث: المقصود بثبات الاستبيان، هو أن يكون علي درجة عالية دن الدقة والإتقان والاتساق فيما يزودنا به من بيانات عن المبحوثين، والاستبيان الثابت هو الذي يعطي نفس النتائج تقريبا إذا ما أعيد تطبيقة علي نفس الأفراد في فترنين زمنيتين مختلفتين، وقد تم حساب معامل

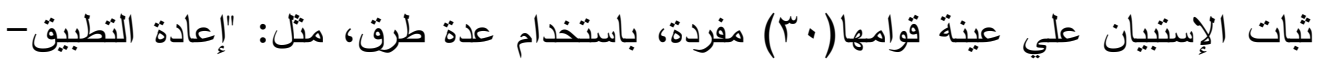

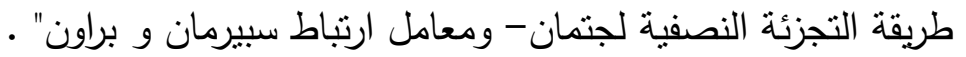

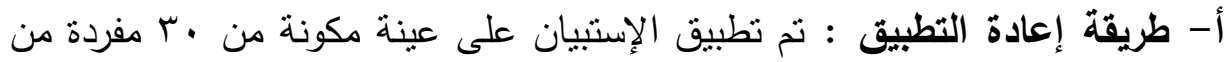
أولياء الأمور ثث أعيد تطبيقه مرة أخرى على نفس العينة بعد فترة زمنية مدتها ثلاثنة أسابيع،

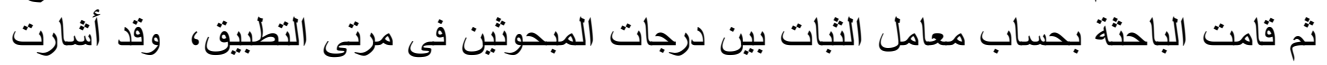
معاملات الارتباط إلي الاتفاق بين الإجابات علي كل بعد من أبعاد الاستبيان بين التطبيقين

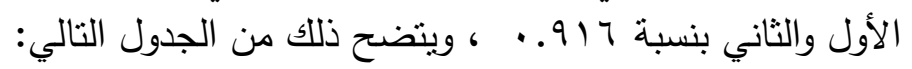

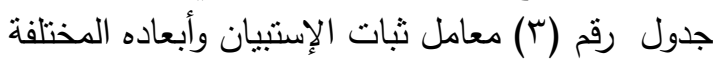

\begin{tabular}{|c|c|c|c|}
\hline 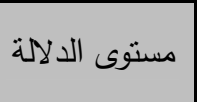 & الثبات & البعد & s \\
\hline |دالة عند ا +... & $\cdot . \wedge r$ & بعد استخدام الإنترنت & 1 \\
\hline دالة عند ا +.. &..$\vee 91$ & بعد استخدام مواقع التواصل الاجتماعى & $r$ \\
\hline دالة عند ا .... & $\cdot . \wedge \vee \uparrow$ & بعد التماس المعلومات عن مشكلات الأبناء من مواقع التواصل الاجتماعى & r \\
\hline دالة عند 1... &. $.91 \mathrm{r}$ & بعد دوافع التماس المعلومات حول مشكلات الأبناء عبر مواقع التواصل الاجتماعى & $\varepsilon$ \\
\hline | دالة عند ا +... & $\because V Y \leq$ & بعد قياس مصداقية مضمون مواقع التواصل الاجتماعى & 0 \\
\hline دالة عند ا ... &..$\times 11$ & بعد الاشباعات المتحققة من استخدام مواقع التواصل الاجتماعى & 7 \\
\hline دالة عند 1 ... &..$\wedge 91$ & الدرجة الكلية & \\
\hline
\end{tabular}


يتضح من الجدول السابق مدى تقارب نسبة الثبات بين الأبعاد المختلفة، وأن معاملات

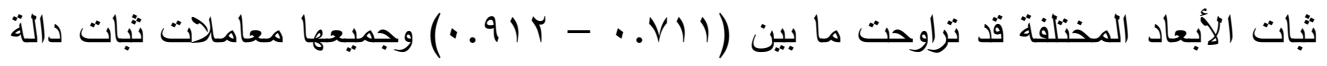

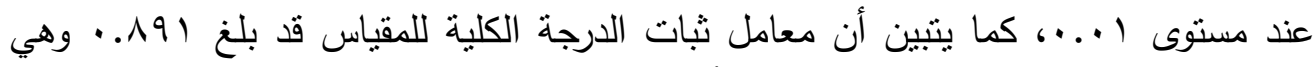

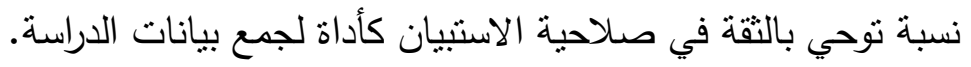

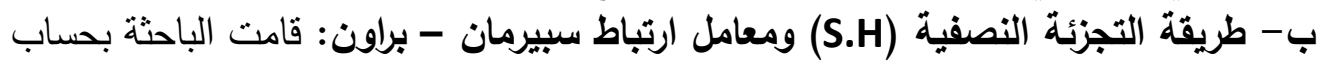

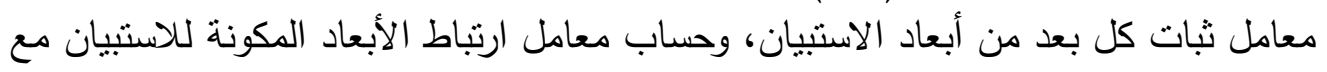

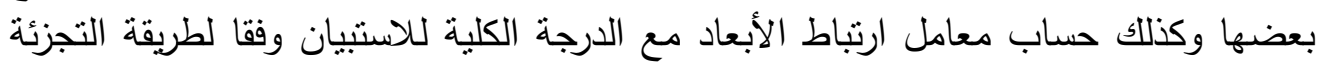
النصفية لجتمان ومعامل ارتباط سبيرمان وبران الابران. جدول رقم (؟ ) معامل ثبات الاستنيان وأبعاده وفقا لطريقة التجزئة النصفية (لجتمان-

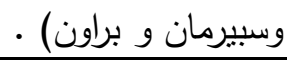

\begin{tabular}{|c|c|c|c|}
\hline سبيرمان - براون & معامل ارتباط التجزئة & 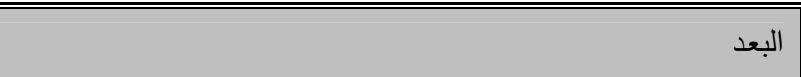 & s \\
\hline..$\wedge 1 Y$ &.$\vee V T I$ & بعد استخدام الإنترنت & 1 \\
\hline..$\wedge 9 \mathrm{~V}$ &. $.91 \mathrm{r}$ & بعد استخدام مواقع التواصل الاجتماعى & r \\
\hline. .170 & $\cdot .9 \cdot 1$ & بعد التماس المعلومات حول مشكلات الأبناء من مواقع التواصل الاجتماعى & $r$ \\
\hline$\cdot . \wedge 9 \Gamma$ & $.94 \varepsilon$ & بعد دوافع التماس المعلومات حول مشكلات الأبناء من مواقع التواصل الاجتماعى & $\varepsilon$ \\
\hline.$\wedge Y_{1}$ & $\because \vee \wedge 9$ & بعد قباس مصداقية مضمون مواقع التواصل الاجتماعى & 0 \\
\hline$\cdot . \wedge \leq Y$ & $\cdot .197$ & بعد الاشباعات المتحققة من استخدام مواقع التواصل الاجتماعى & 7 \\
\hline$\cdot . \wedge \vee 1$ &.$\wedge 9 \wedge$ & معامل ارتباط الأبعاد مع بعضها & * \\
\hline .941 &. $.91 \mathrm{r}$ & ا ارتباط الأبعاد مع الدرجة الكلية & * \\
\hline
\end{tabular}

يتضح من الجدول السابق أن أبعاد الاستبيان حققت معاملات ثبات علي درجة معقولة الألة

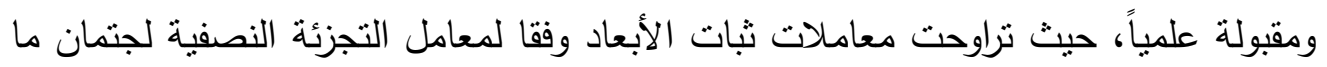

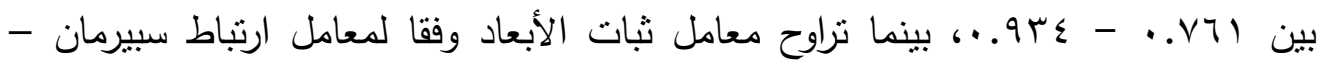

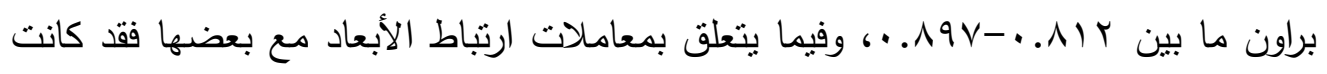

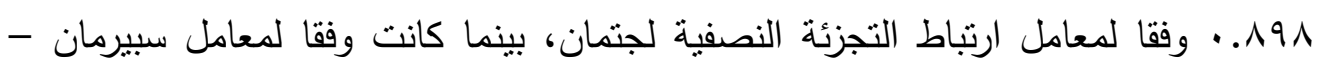
براون ل AV . . ، وهي معاملات ثبات عالية وتدل علي ثبات الأبعاد، وفيما يتعلق بمعاملات

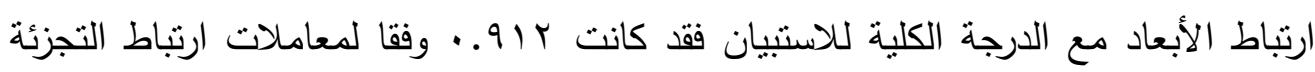

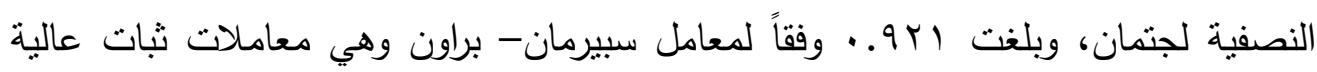

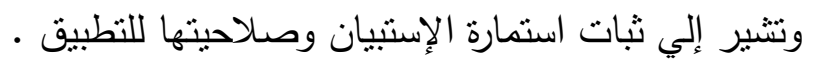

- كما استخدمت الدراسة عدة مقاييس، قامت الباحثة بتصميمها لقياس متغيرات الدراسة : المتغير المستقل: مقياس معدل إلتماس الوالدين للمعلومات عن مشكلات أبنائهم من مواقع

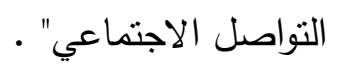


المتغيرات الوسطية: مقياس للمتغيرات الديموجرافية لعينة الدراسة (النوع "ذكر - أنثى"- السن

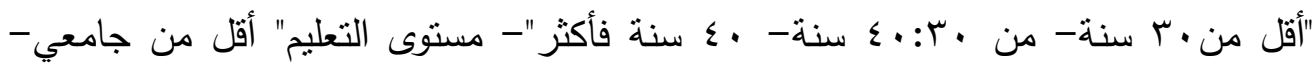

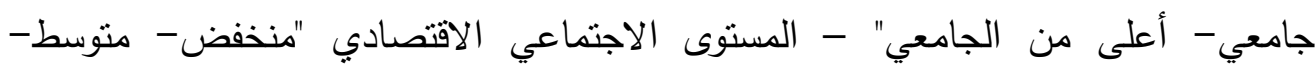
مرتفع"- مكان الإقامة "محافظة الغربية- محافظة القاهرة". المتغير التابع : "مقياس الاشباعات المتحققة للوالدين نتيجة استخدامهم لمواقع التواصل الاجتماعي لالتماس المعلومات عن مشكلات أبنائهر. الإطار المعرفى للاراسة : مإن مشكلات مرحلة الطقولة:

إن مرحلة الطفولة مرحلة هامة جدا في تكوين شخصية الإنسان، ولها تأثثر كبير جدا

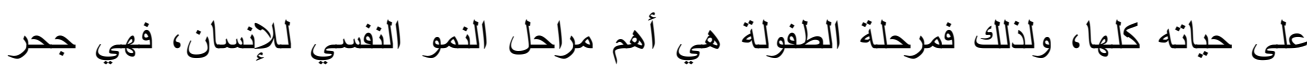

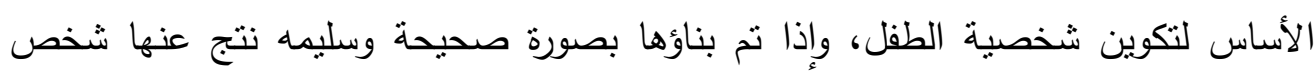
مثالي يستطيع مواجهة صعوبات الحياة بكل ثبات وثقة (זr)، وعلى هذا ركزت الباحثة في دراستها الحالية على: المشكلات والسلوكيات الخاطئة التى تنتشر بين الأطفال في مرحلة ولئه

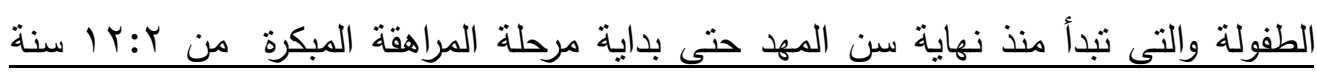

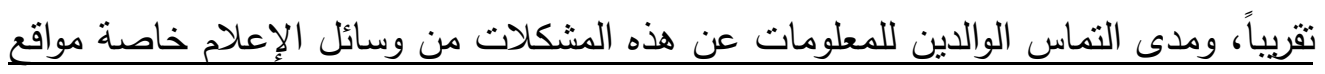
التواصل الاجتماعي والإثباعات التي تحقق لهم نتيجة هذا الالتماس. 1- مشكلة الخوف: معظم الأطفال لديهم مخاوف كثيرة، وكلما كبر الطفل فإن خيالة وتفكيره

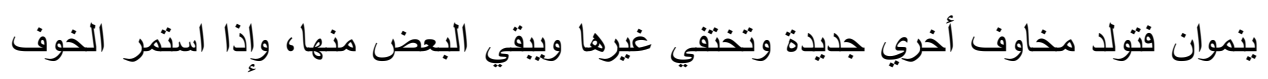

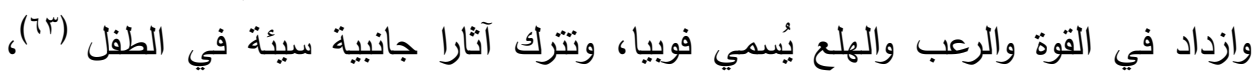

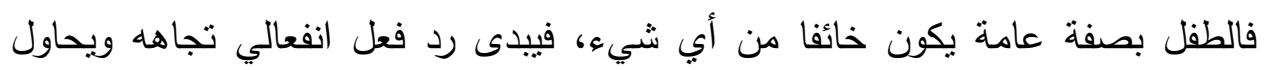

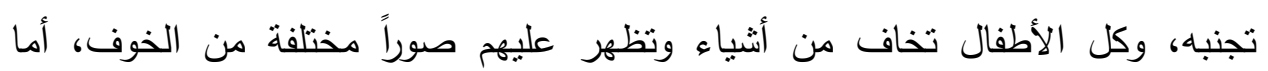

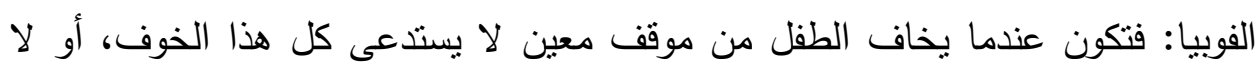

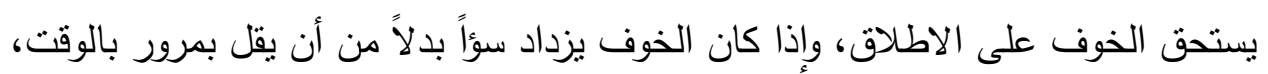
فهنا نسمى الخوف فوبيا ويصبح مشكلة.

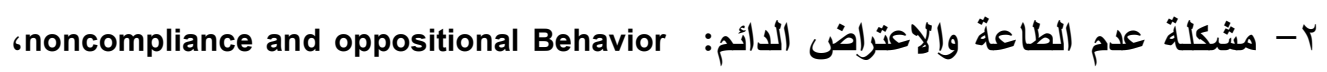
وهى من أكثر السلوكيات السيئة التي تضايق الوالدين جدا من أطفالهه، ولكن يجب ألا 
نُرغم الطفل على الطاعة المفرطة لأن ذلك يجعله مطبعاً لأي شخص آخر الغرباء مثلا،

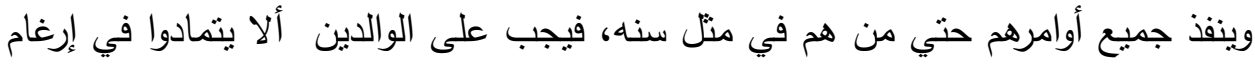
الطفل على الطاعة باستمرار لأنها هي أيضا مشكلة كبيرة تؤثر على الطفل بصورة سلبية،

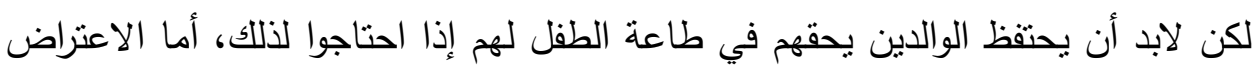

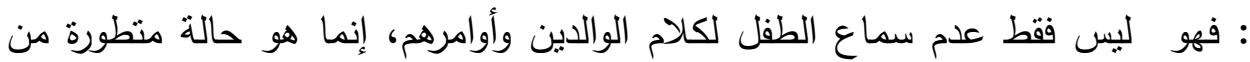
حالات عدم الطاعة، كأن يقوم الطفل برفض طلبات والدية أو عمل عكس ما بطلبوه منه. إن عدم الطاعة يكون مقبولاً حتى سن الخامسة أما من سن السادسة ودخول المدرسة "

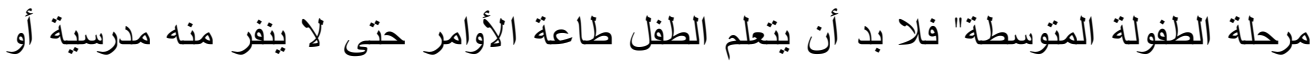
أصدقائه ويتهمونه بعدم التعاون والمشاركة، ومن أهم أسباب عدم الطاعة أن يكون الطفل

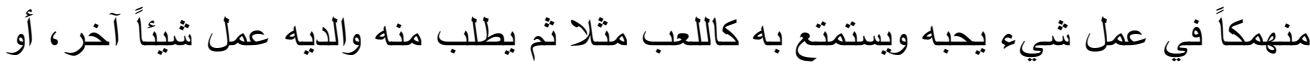

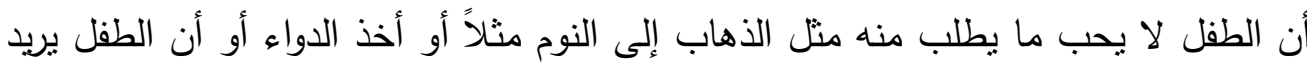

أن يري رد فعل والديه على عدم طاعته ويستمتع بغضبهر وعصبتيهر.

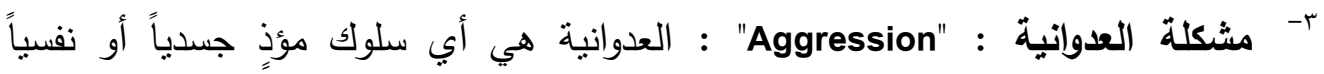

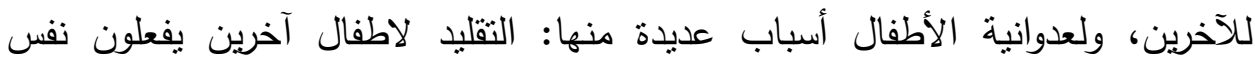
السلوك، أو ربما يشاهدون ذلك في وسائل الإعلام أو من الآباء وعندما يتعرض الطفل الطفال

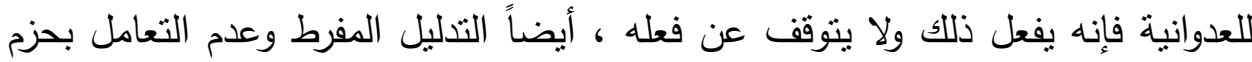
مع الطفل عندما يفعل سلوك غير سليم، أو الإسراف في استخدام الرفض والعقاب قابف قد يزيد

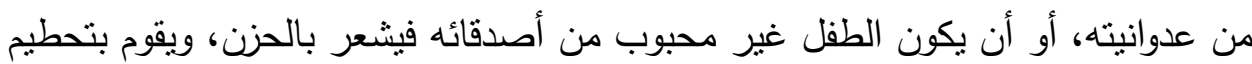

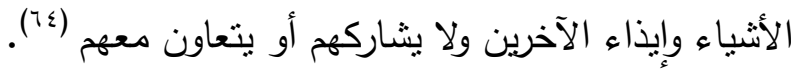
ع- مشكلة النشاط الزائد وقلة التركيز: Hyperactivity : تعد مشكلة النشاط الزائد ورئ وقلة التركيز من أكبر وأهم الششكلات التي يعاني منها الطفل، ومن أعظم الثكاوى الثائعة

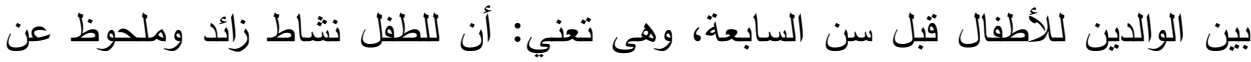

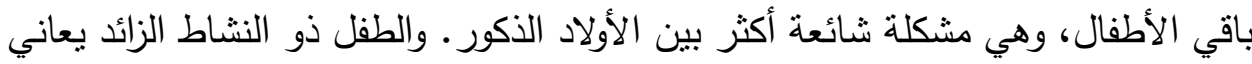

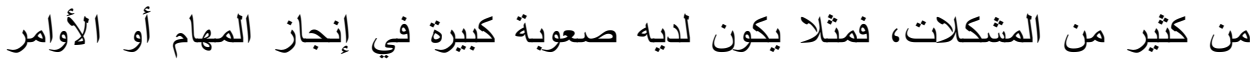
والتعليمات التي تلقى اليه، فلا يكملها، وتكون عنده مشكلات في الفهم والتعلم وممارسة

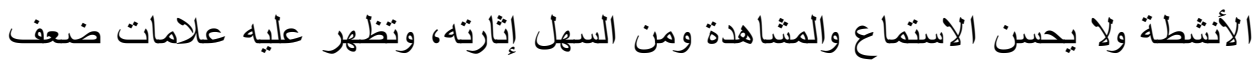

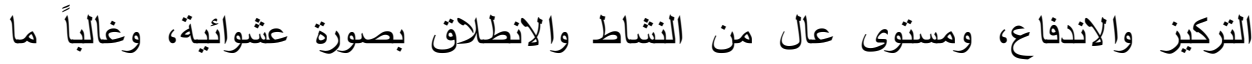


يتصرف بدون تفكير ، ويجد صعوبة في انتظار دوره في اللعب، ويصعب السيطرة عليه، أو الإستقرار في مكان أو الجلوس لفترة مستقرا خاصة في الفصل الدراسي، ويتحرك كثيرا أثناء النوم، ويتحرك كأنه يعمل بموتور (70) . ه- مشكلة الثعور بالنقص والانطواء: وهي مشكلة منتشرة حالياً في العالم بين عدد كبير من بن بون

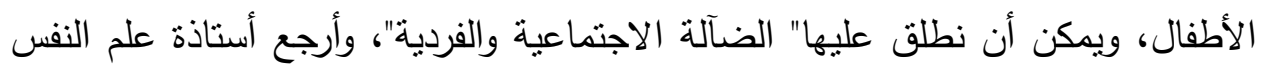
أسباب انتشار وهذه الظاهزة بين الأطفال الي مؤثرات مرضية وخلقية، وعوامل تربوية

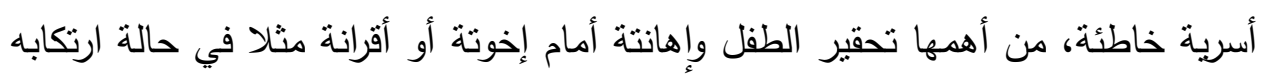
للأخطاء، أو التدليل المفرط للطفل مما بشعره بالخجل والخنوع والانطواء على الذات،

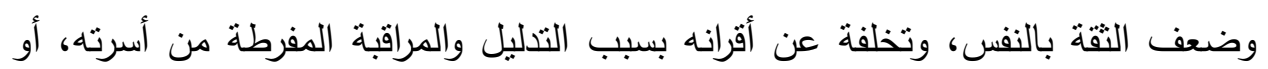
المفاضلة بين الأبناء والتفرقة بين الطفل وإخواتة مما بشعره بالنقص والكراهية لأسرته، أيضا الإعاقة الجسدية وما تولده من إحساس كبير بالنقص لدى الطفل حيث يقارن نفسه لئه

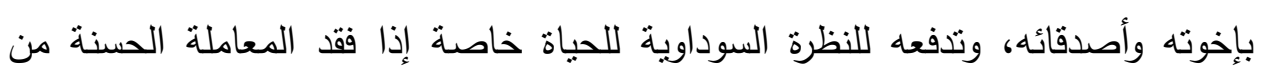

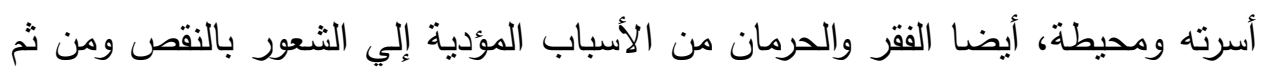

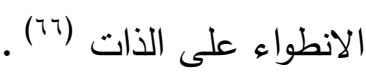
7- مشكلة الكذب: وتعد من الآفات الأخلاقية الخطيرة لدى الأطفال، والكذب نقيض الصدق،

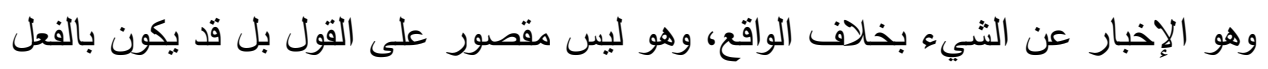
أو الإثارة أو بالسكوت أيضاً، والأسرة طرف أساسي وفعال حيث يمكنها غرس الإن العادات

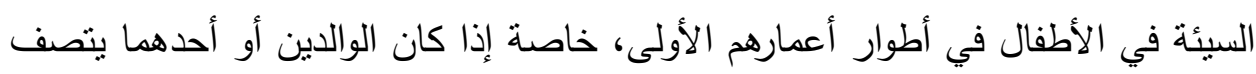

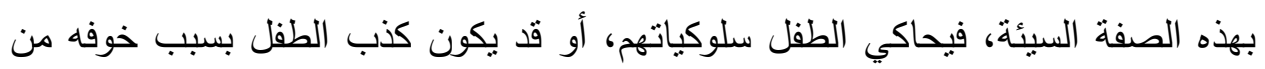

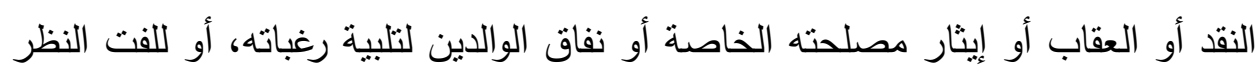

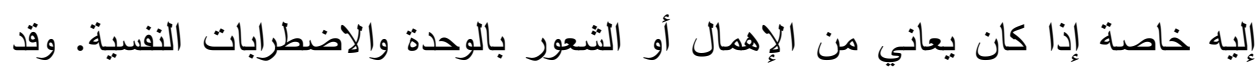

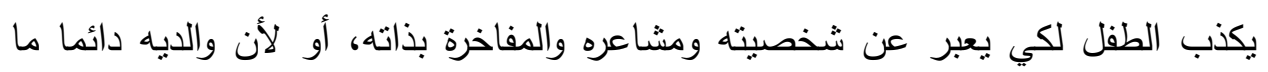

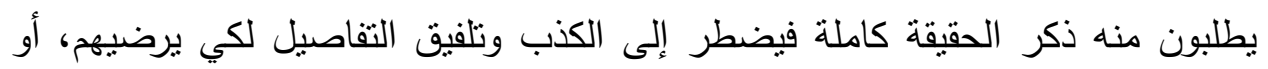
بسبب الضرب المبرح من والديه والقسوة المبالغ فيها، وخيال الطفل الواسع في هذه

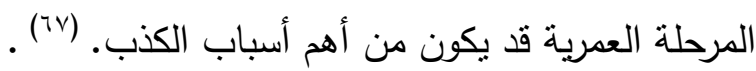

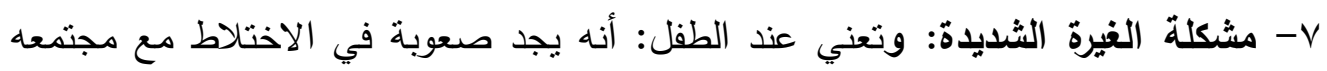
الأسري، لأنه لم يحصل على قدر من الوقت والرعاية والعدل منهم، وبالتالي يفتقد إلى الى فئل 
العطف من قبل والدية الذي كان يعتبرها أكثر الناس حبا ومعزة له ، ويؤكد الطب النفسي أن إحساس الطفل بالغيرة يحط من عزة نفسه، ويدفعه إلى الإحباط والثُعور بالفشل

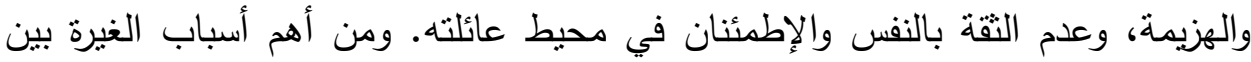
الأطفال هو عدم عدل ومساواة الوالدين في معاملته أطفالهم، والرحمة بينهم بسبب ولإنه اختلاف الجنس أب البنت والولد مثنلاً، أو لذكاء أحدهم، أو بسبب ميلاد طفل جديد في

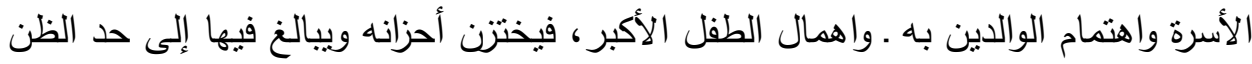
السيئ بغيره، ويفكر بأن الدنبا كلها ضده، وبذلك قد بسبب الكثير من المتاعب لأهله الذين هم السبب فيما هو عليه، وقد يكون خطرا في سلوكياته ومهددا بالانفجار في أيه لحظة (^^).

1- مشكلة السرقة: وهى من أسوأ المشكلات التي تواجه الوالدين مع أطفالهم خاصة عند

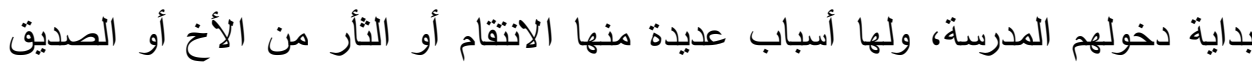

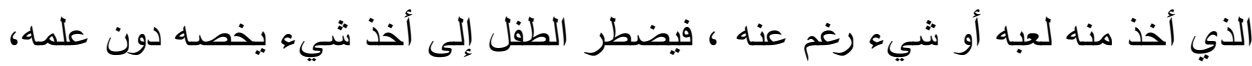

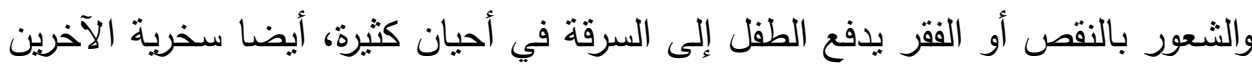

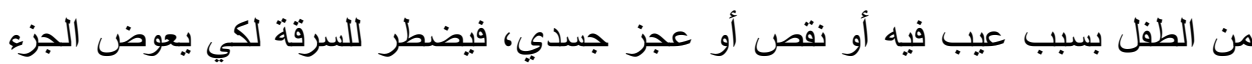
الناقص في شخصيته، كما أن الغيرة عاملاً خطيراً في معظم السلوكيات المنحرفة للأطفال

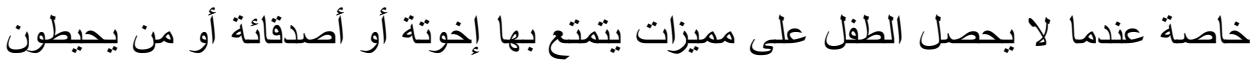

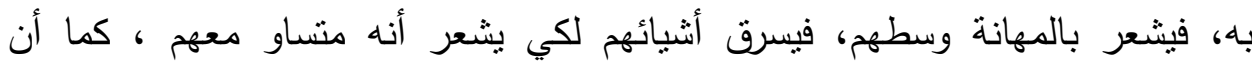

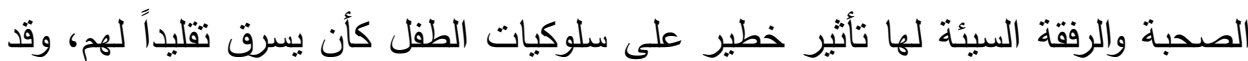
تكون السرقة ناتجة عن مبالغة الوالدين في تعليم الطفل التوفير والمحافظة على مصروفة،

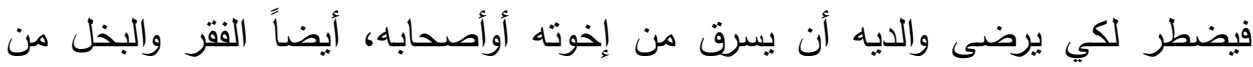

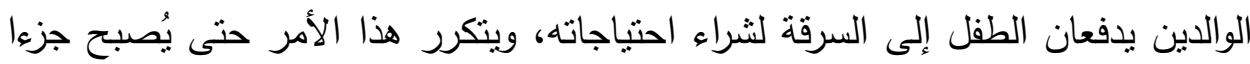

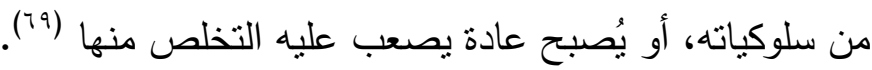
9 - مشكلة إدمان وسائل الإعلام الجديدة : لا شيء يواجه الأب والأم اليوم أثند خطورة وأكثر

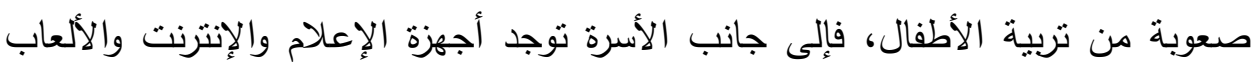

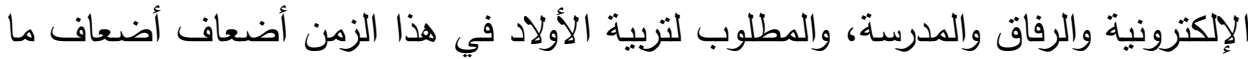

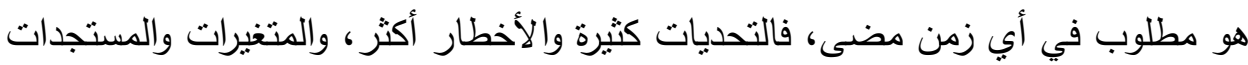
تعصف بكل شيء وموازين الأمور تختل. 
لقد فرضت وسائل الإعلام الجديدة والهاتف النقال والإنترنت والألعاب الإككترونية نفسها علينا وعلى تربية وتتشئة أطفالنا بما لها من إيجابيات وسلبيات، لذا وجب إلب على الوالدين

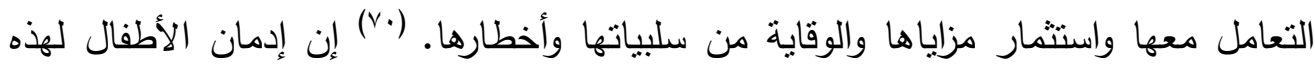

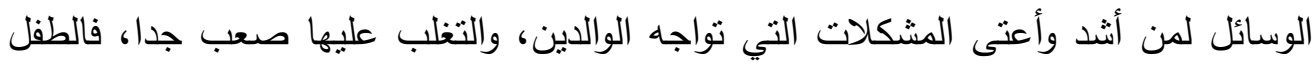

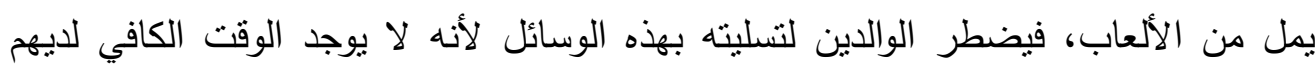

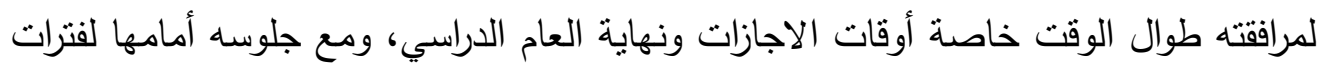

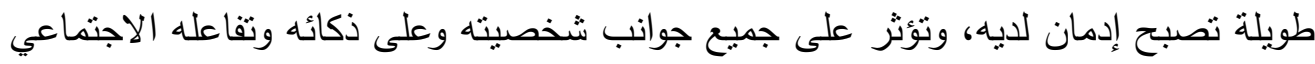

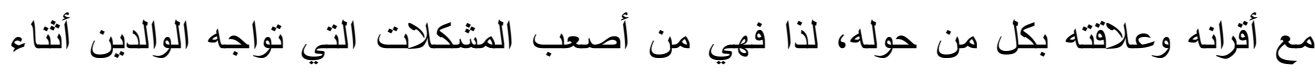

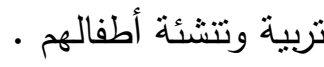

• 1 - مشكلة الطمع : هو نوع من الإرادة الغير قابلة للقناعة، يتصف بها الطفل، حيث يسعى

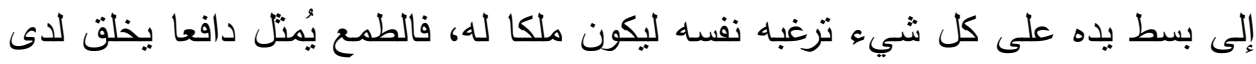

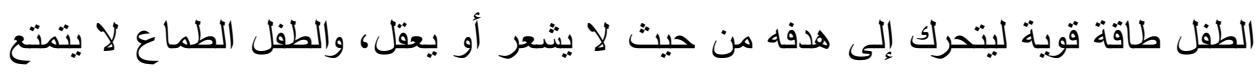

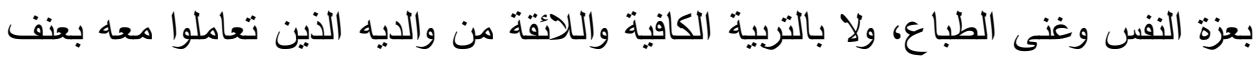
وشدة ، والطمع عند الأطفال له صور وأثكال عديدة، أبرزها هو الطمع في التملك، فإذاذ ما شاهد الطفل شيئا عند غيره فإنه يرغب في أن يكون ملكا له ويتحرك للاستيلاء عليه، وقد يقود الطمع الطفل إلى المشاحنة والعراك للحصول على ما يريد من الآخرين بصورة

$$
\text { مبالغ فيها (v) }
$$

ومن أهم أسباب الطمع سوء تربية الوالدين لأطفالهم، حيث لهم دورا أساسيا في ابتلاء

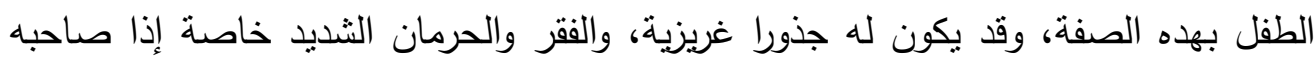

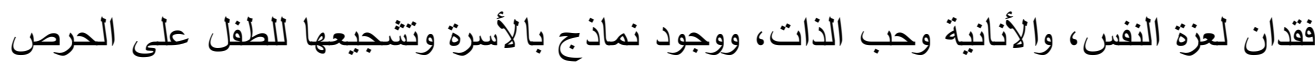
والبخل والخوف الثديد على المال وجمعه، كلها تدفع الطفل لأن يكون طماعا متل والديه (Vr)

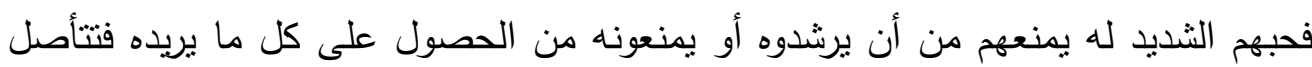
فيه صفة الطمع، ويكون عُرضة للفساد والانحراف. 11- مشكلة الغضب الثديد: إن الغضب يعني الثورة الثديدة من الطفل وتتمنل في مظاهر عدة : الصباح والصوت العالي والبكاء الثديد وايزاء النفس كضرب الرأس بالحائط أو أي لفي شيء أمامه أو عض نفسه أو جرح نفسه أو إيزاء نفسه بأي صورة من الصور للحصول 
على ما يُريد، ويُصبح الغضب الثنديد مشكلة إذا استمر مع الطفل بهذا الثكل حتى بداية دخوله سن المدرسة، وإذا استخدم الطفل هذا السلوك كلما أراد شيئا ما في نفس اللحظة لهنة كالطعام أو لُعبة مثنا وتتفيذ جميع طلباته، وللفت انتباه والديه، أو لكي لا يفعل ما يطلبه

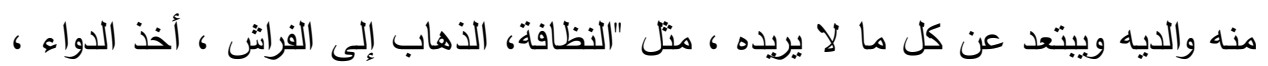
أداء الواجبات المدرسية ...." (Vr). r ا - مشكلة التبول اللاإرادي : وتُعد مشكلة التبول اللاإرادي أو "سلس البول الليلي" عند

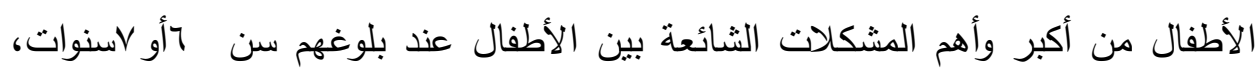
مما يُسبب القلق والحرج والانزعاج للطفل ووالديه أيضا، خاصة وأنها تترك أثارا نفيسة

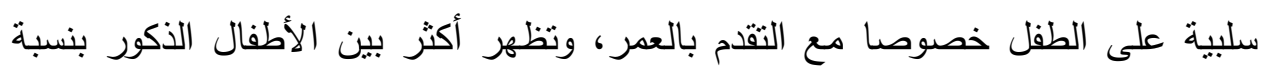

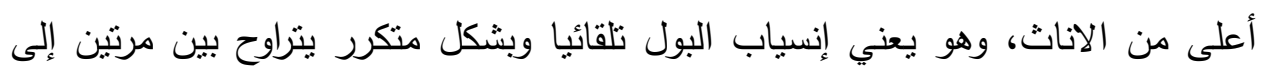
ثلاث مرات أسبوعيا عند الطفل الذي تجاوز سن الثثلاث سنوات خلال النهار أو أثناء النوم .

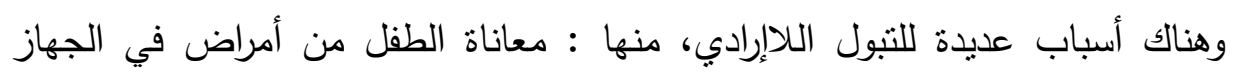

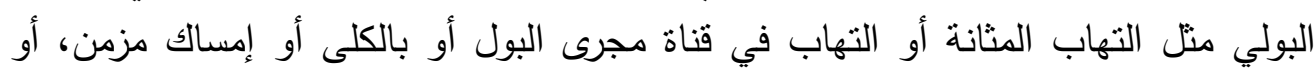

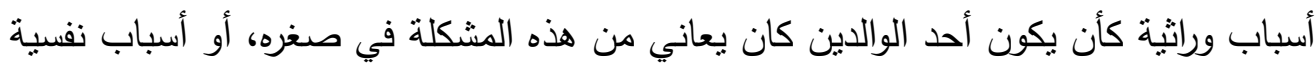

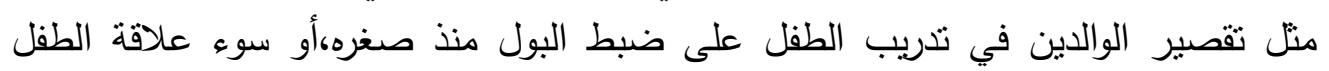
بأمه، أو العنف وضرب الطفل بقسوة وحرمانه لكي يتعلم التحكم في البول مبكل فلبكرا، أوتدليل

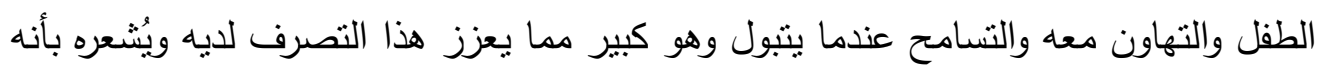

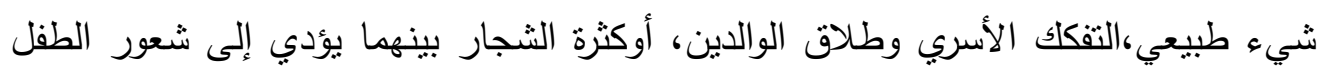

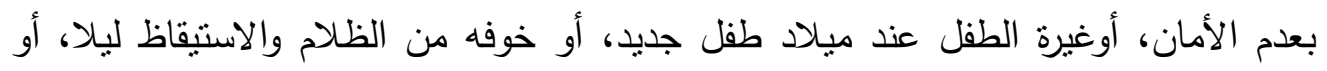

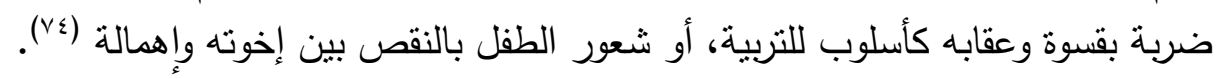

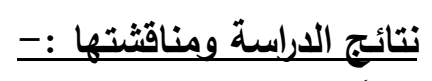
أولاً: الإجابة على تساؤلات الإراسة ومنافئية

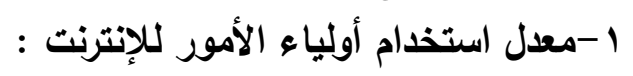

طبقت الدراسة على عينة عشوائية قوامها ل ..ـ مفردة من أولياء الأمور ، إلا أنه ليست

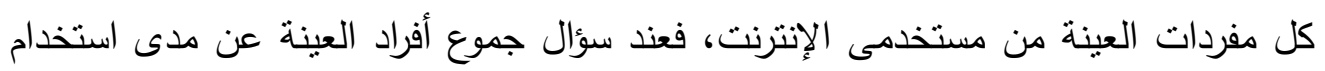

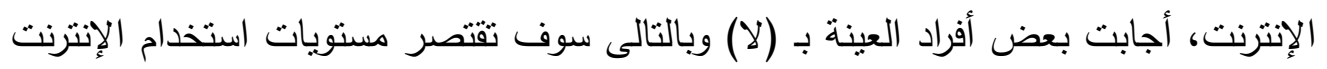

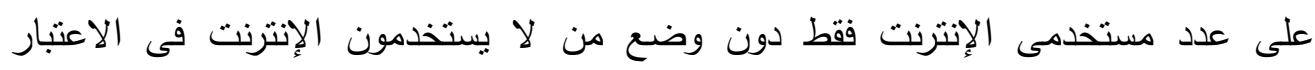

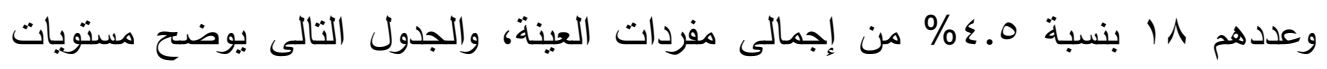

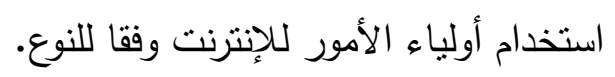


جدول (0) مستوى استخدام أولياء الأمور للإنترنت وفقا للنوع

\begin{tabular}{|c|c|c|c|c|c|c|}
\hline \multicolumn{2}{|c|}{ الإجمالى } & \multicolumn{2}{|c|}{ إناث } & \multicolumn{2}{|c|}{ ذكور } & \multirow[t]{2}{*}{ النوع } \\
\hline$\%$ & 5) & $\%$ & ك5 & $\%$ & 5 & \\
\hline$\sum r_{.10}$ & 171 & $\varepsilon r_{.} \cdot \Lambda$ & $\Lambda$. & $E Y . Y Y$ & $V 7$ & مرتفع \\
\hline 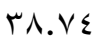 & $1 \leq 1$ & rV.Tr & $V Y$ & $\varepsilon \ldots$ & $V Y$ & متوسط \\
\hline 19.11 & VT & $r . . r$. & $\varepsilon$. & $I \vee . \vee \wedge$ & rr & منخفض \\
\hline $1 \ldots$ & TAT & $1 \ldots$ & $19 \varepsilon$ & $1 \ldots$ & 11. & الإجمالي \\
\hline
\end{tabular}

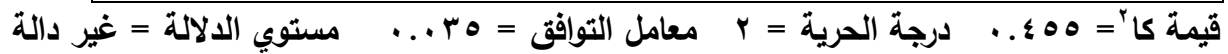
توضح نتائج الجدول السابق عدم وجود علاقة دالة إحصائياً بين النوع (ذكور - إناث) ومستوى استخدام أولياء الأمور للإنترنت (مرتفع- متوسط- منخفض)، حيث بلغت بـت نسبة

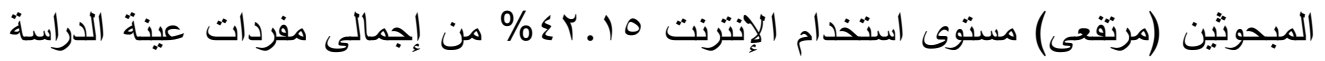
البالغ عددهم r r r مفرده ، بينما بلغت نسبة المبحوثين (متوسطى) مستوى استخدام الإنترنت

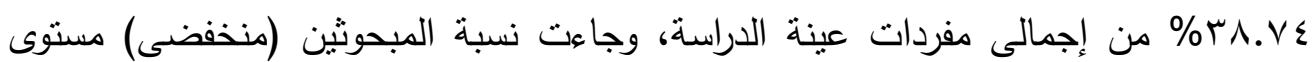

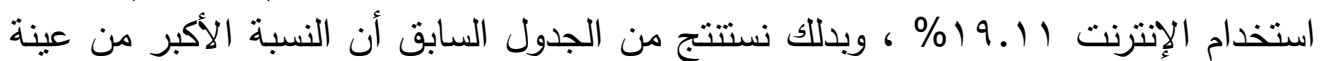

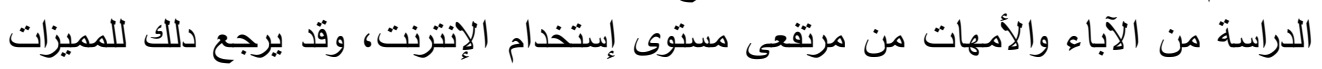

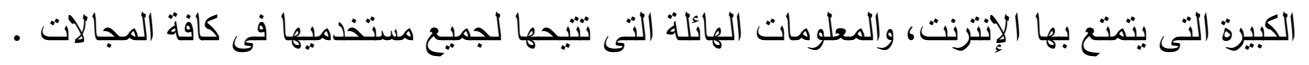

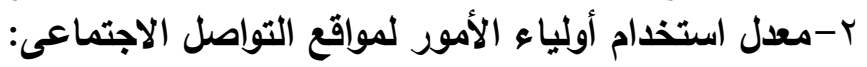

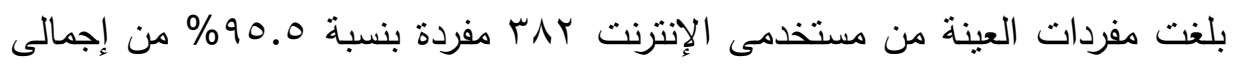

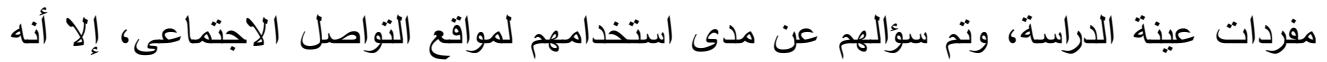
ليس كل من يستخدم الإنترنت مستخدماً لمواقع التواصل الاجتماعى، فعند سؤال مستخدمى

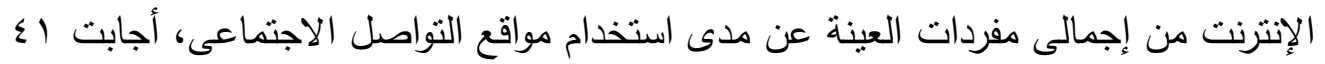
مفردة من أفراد العينة بـ (لا)، وبالتالى سوف تقتصر مستويات استخدام أولياء الأمور لمواقع مدئ مدئ

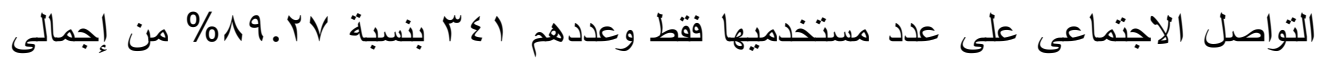
مفردات من يستخدمون الإنترنت من إجمالى مفردات عينة الدراسة، والجدول التالى يوضح

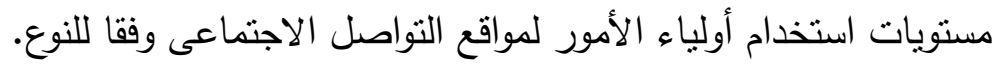

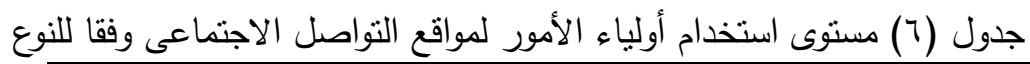

\begin{tabular}{|c|c|c|c|c|c|c|}
\hline \multicolumn{2}{|c|}{ الإجمالى } & \multicolumn{2}{|c|}{ إناث } & \multicolumn{2}{|c|}{ ذكور } & \multirow{2}{*}{ معدل الاستخدام } \\
\hline$\%$ & ك5 & $\%$ & 5) & $\%$ & 5 & \\
\hline $0 \Sigma . \wedge \varepsilon$ & $1 \wedge V$ & or.TV & 90 & 07.1. & $q r$ & مرتفع \\
\hline rq.rq & 9. & 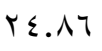 & $\varepsilon \varepsilon$ & YA.. 0 & $\leqslant 7$ & متوسط \\
\hline $1 \Lambda . V V$ & $7 \varepsilon$ & YI. $\leqslant V$ & rᄉ & 10.10 & rt & منخفض \\
\hline $1 \ldots$ & $\Gamma \leqslant 1$ & $1 \ldots$ & $I V V$ & $1 \ldots$ & $17 \varepsilon$ & الإجمالي \\
\hline
\end{tabular}

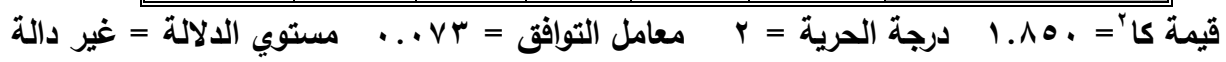


تؤكد نتائج الجدول السابق عدم وجود علاقة دالة إحصائياً بين النوع (ذكور - إناث)

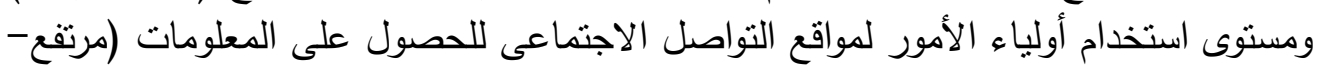

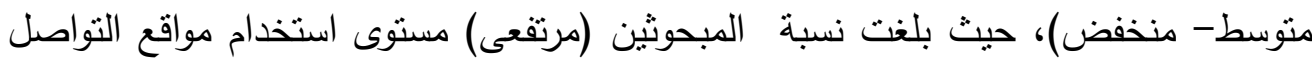

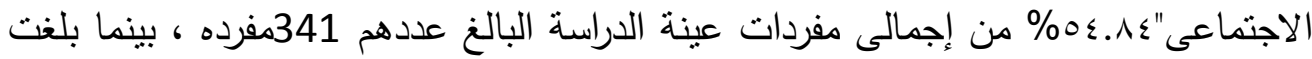

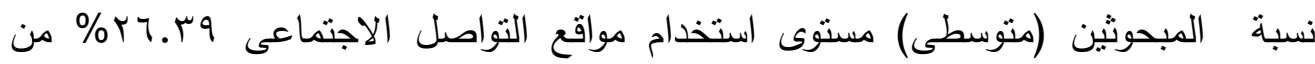

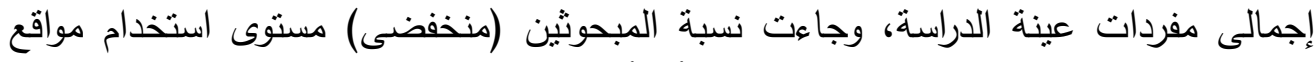

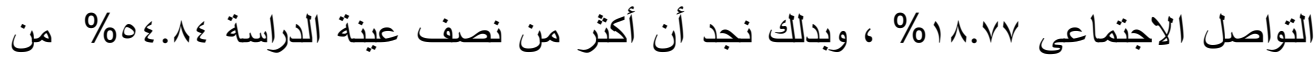

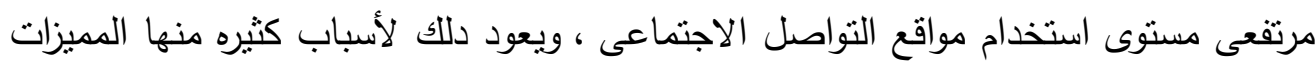

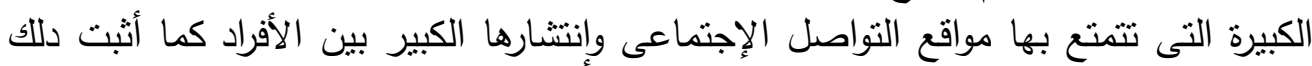

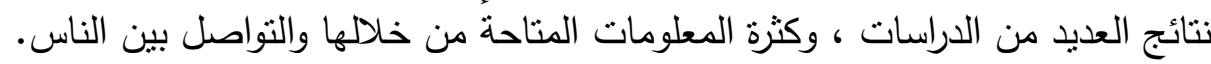

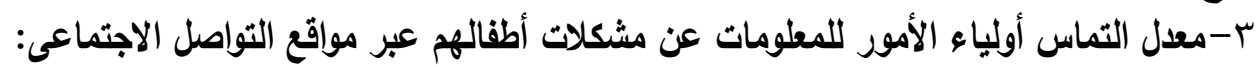

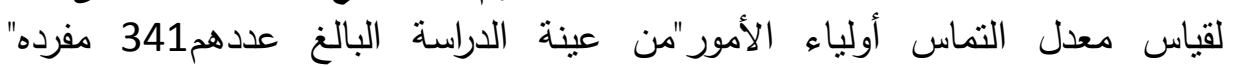

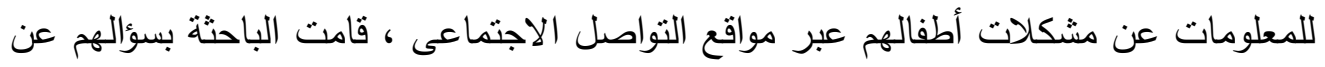

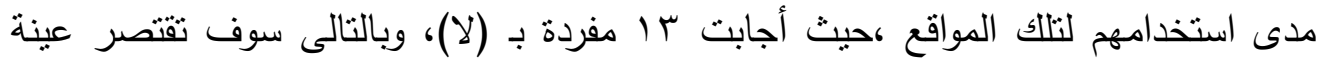

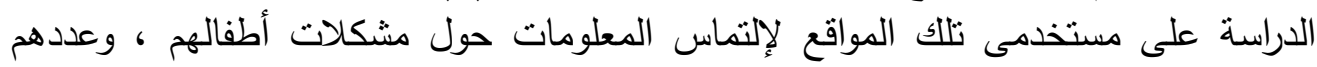

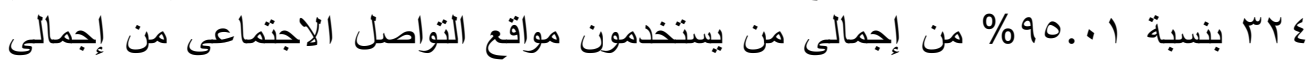

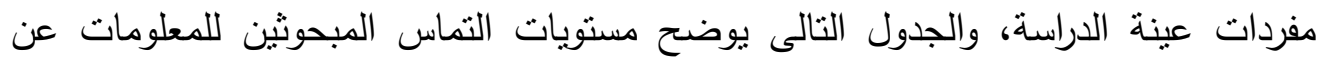

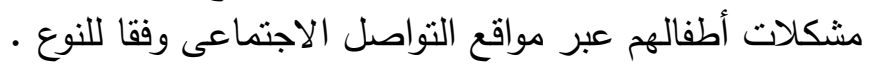

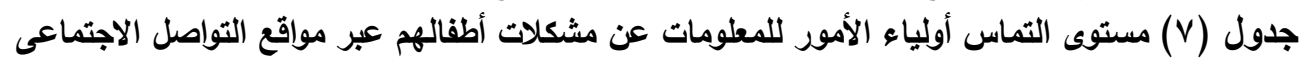

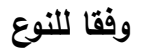

\begin{tabular}{|c|c|c|c|c|c|c|}
\hline \multicolumn{2}{|c|}{ الإجمالى } & \multicolumn{2}{|c|}{ إناث } & \multicolumn{2}{|c|}{ ذكور } & \multirow[t]{2}{*}{ النوع } \\
\hline$\%$ & 5 & $\%$ & ك & $\%$ & 5 & \\
\hline 01.10 & 171 & $\{9 . \leqslant 1$ & $\wedge \varepsilon$ & $0 \leqslant .00$ & $\Lambda \varepsilon$ & مرتفع \\
\hline YA. . 9 & 91 & Yq. $\leqslant 1$ & 0. & Y7.7Y & $\sum 1$ & متوسط \\
\hline$r \cdot . \cdot T$ & 70 & 1.11 & דr & 1ᄉ.Ar & rq & منخفض \\
\hline $1 \ldots$ & TYE & $1 \ldots$ & IV. & $1 \ldots$ & 105 & الإجمالي \\
\hline
\end{tabular}

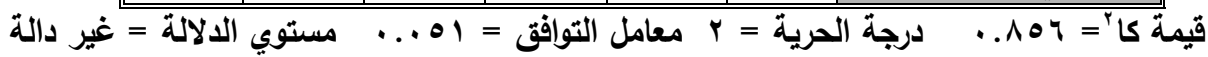

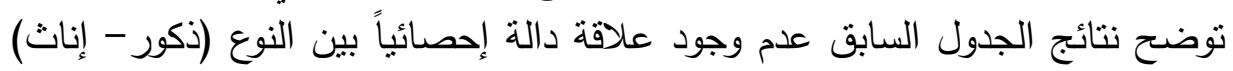

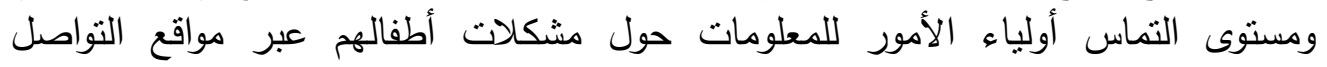

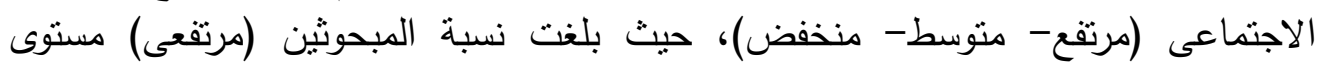

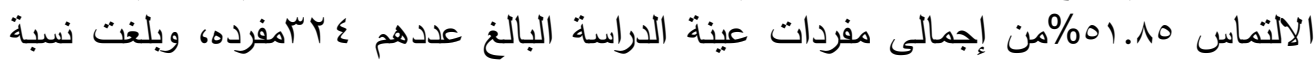

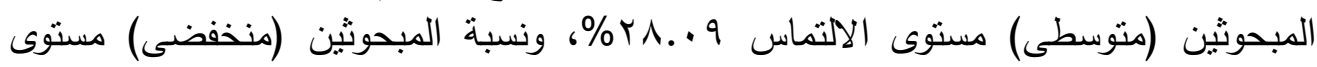

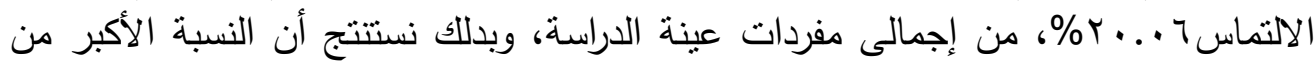

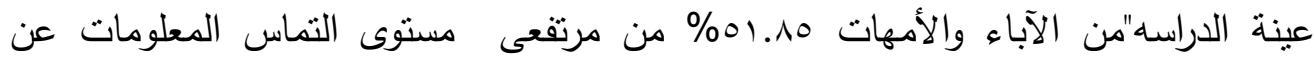


مشكلات أطفالهم من مواقع التواصل الإجتماعى، وقد يرجع دلك إلى :كثره المعلومات المتاحه

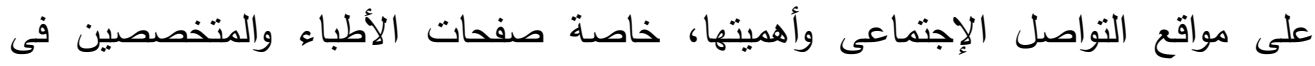
مجالات الطفوله ومشكلاتها والدين يكتبون عن تلاكت المشكلات وكيفية التغلب عليها، ولئات ويردون

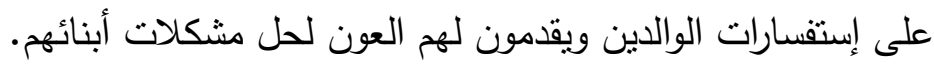

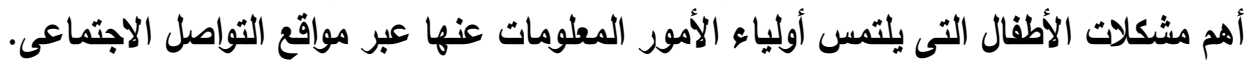

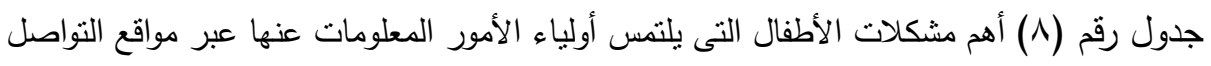
الاجتماعى وفقا للنوع.

\begin{tabular}{|c|c|c|c|c|c|c|c|c|c|}
\hline \multirow{2}{*}{ ?ר? } & \multirow{2}{*}{ 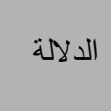 } & \multirow{2}{*}{ قيمة z } & \multicolumn{2}{|c|}{ الإجمالي } & \multicolumn{2}{|r|}{ إناث } & \multicolumn{2}{|r|}{ ذكور } & \multirow{2}{*}{ المشكلات } \\
\hline & & & $\%$ & 5] & $\%$ & 5) & $\%$ & 5) & \\
\hline 0 & دالة** & 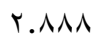 & 纟7.r. & 10. & סT.ror & 19 & फ..7) & 71 & العدوانية \\
\hline$\wedge$ & غير دالة & $\cdots \cdots$ & r.AT & $1 \cdots$ & rq. $\leqslant 1$ & 0 . & T. Y. VV & 0 . & الغيرة الثديدة \\
\hline 1. & غير دالة & $1.7 \leq$ & $r . .99$ & $7 \wedge$ & סחוזי & ب & $19 . \leqslant 1$ & r. & 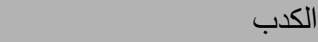 \\
\hline r & غير دالة & 1.517 & VI. 7 . & Trt & סT.T & سr| & $\vee \cdot . \vee \wedge$ & 1.9 & الطمع والأنانية \\
\hline 9 & غير دالة & $1 . r .7$ & YV.1T & $\wedge \wedge$ & rY.qE & pq & T.Ar & $\varepsilon 9$ & الخوف الثديد \\
\hline 1. & غير دالة & טצד & $r . .99$ & 71 & $19 . \Sigma 1$ & 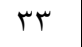 & TY.VT & ro & الانطواء والشعور بالنقص \\
\hline 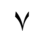 & دالة * & r.97. & . & $1 \cdot \varepsilon$ & rᄉ.Y & 70 & ro.rt & rq & التبول الإرادى \\
\hline$\varepsilon$ & غير دالة & $\cdot . \varepsilon \cdot 1$ & 07.199 & $1 \wedge \varepsilon$ & 00.19 & $9 \leq$ & $0 \wedge . \leq \varepsilon$ & 9. & عدم ائم الطاعة والاعتراض \\
\hline$r$ & غير دالة & . r.. & $T \Sigma . Y$. & $r \cdot \Lambda$ & $7 . .09$ & $1 \cdot r$ & 71.11 & 1.0 & النشاط الزائد وقلة التركيز \\
\hline 7 & غير دالة & $1 . . \leqslant V$ & $\{r . Y !$ & $1 \leq$. & $\varepsilon \varepsilon .1 T$ & vo & $\sum r . r \mid$ & 70 & الغضب الثديد \\
\hline 11 & دالة & $r . . v q$ & 17.0 & or & 11.11 & 19 & Y..$\leqslant T$ & 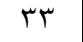 & السرقة \\
\hline 1 & غير دالة & 1.77. & V^.乏. & ros & $\vee 9 . \leqslant 1$ & 150 & VV.YV & 119 & إدمان وسائل الإعلام الجديده \\
\hline & & & & TrE & & iv. & & $10 \leqslant$ & جملة من سئلوا \\
\hline
\end{tabular}

توضح نتائج الجدول السابق أهم مشكلات الأطفال التى يلتمس أولى أولياء الأمور

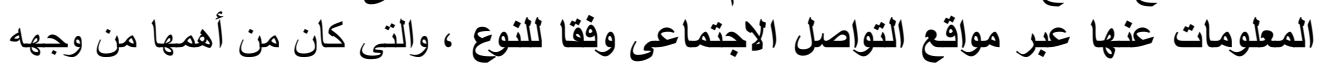

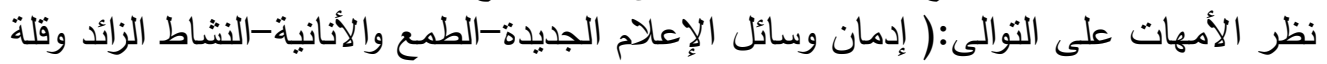

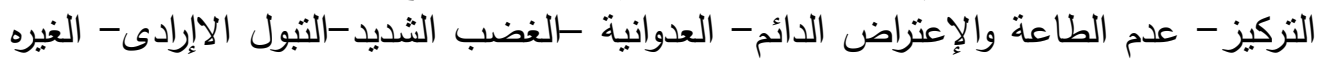

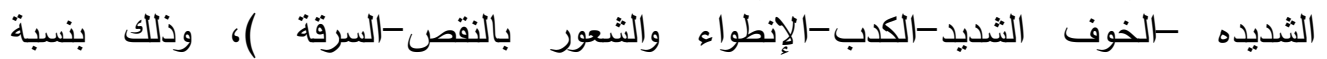

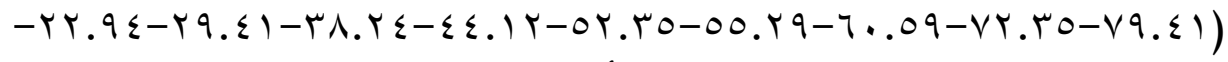

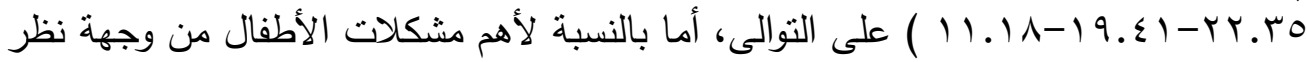

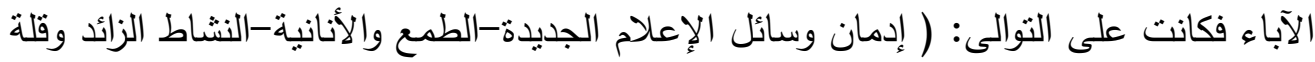

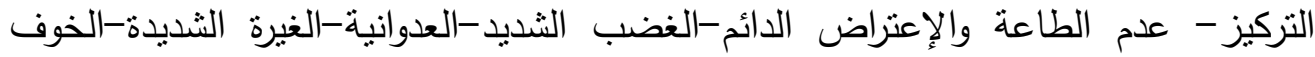

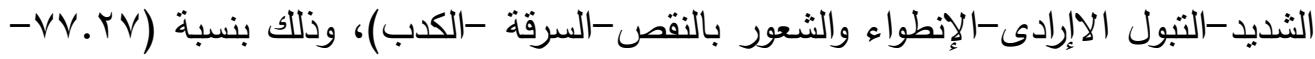

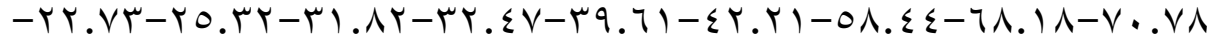

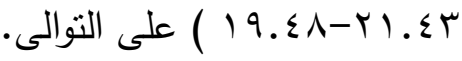


كما أظهرت النتائج التقصيلية للجدول السابق، عدم وجود فروق دالة إحصائيا بين

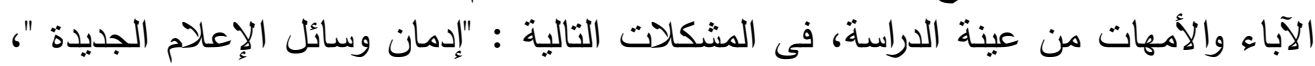

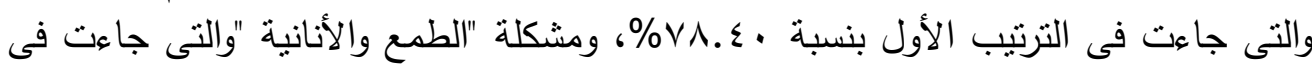

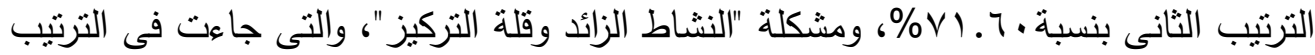

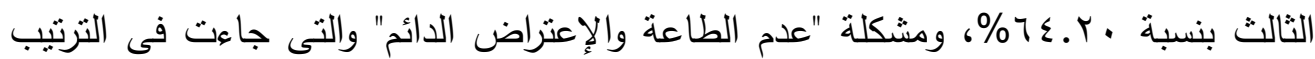

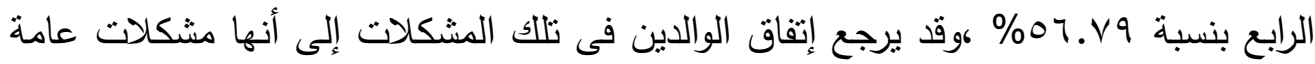

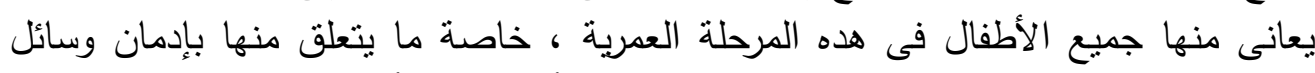

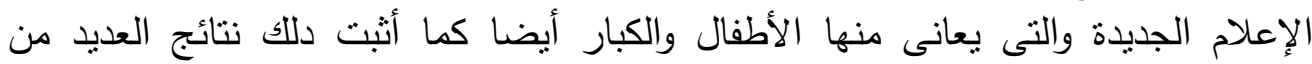

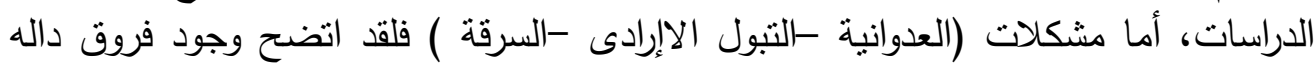

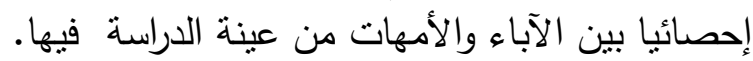
ه- أهم دوافع التماس أولياء الأمور للمطلومات لأنهات حول مشكلات أطفالهم من مواقع التواصل الاجتماعى. - التع

جدول رقم (9) أهم دوافع التماس أولياء الأمور للمطومات حول مثكلات أطفالهه من مواقع التواصل

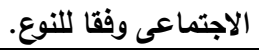

\begin{tabular}{|c|c|c|c|c|c|c|c|c|c|}
\hline \multirow{2}{*}{ 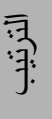 } & \multirow{2}{*}{ الدلالة } & \multirow{2}{*}{ ق قيمة z } & \multicolumn{2}{|c|}{ الإجمالي } & \multicolumn{2}{|r|}{ | إناث } & \multicolumn{2}{|c|}{ ذكور } & \multirow{2}{*}{ الدوافع } \\
\hline & & & $\%$ & 5) & $\%$ & 5) & $\%$ & 5) & \\
\hline 7 & دالة & r.rVT & 17.00 & or & $1 . .09$ & 11 & $r r_{.} . \Lambda$ & $r \varepsilon$ & وأبعادها آتعمق في فهم المشلفي \\
\hline 1 & غير دالة | & 1.199 & $09 . \wedge 1$ & $19 \varepsilon$ & $7 . .09$ & $1 . r$ & $09 . .9$ & 91) & 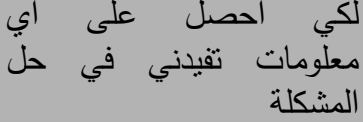 \\
\hline$\varepsilon$ & غير دالة| & $. . \leqslant T \leqslant$ & rV.To & ITY & $r \varepsilon . v 1$ & 09 & $\varepsilon . .91$ & Tr & واللتعرف على آراء الأطباء \\
\hline $\mathrm{v}$ & غير دالة| & אזr.. & Ir.ro & $\varepsilon$. & 11.11 & 19 & $1 T .7 \varepsilon$ & YI & للاديهر نفس المشى آولياء امور \\
\hline 1 & دالة *** & $T . M V T$ & 0.07 & 11 & $9 . \leqslant 1$ & 17 & $1 . \mu$. & r & المشكلة اللتواصلَ لمساعدتي في حل \\
\hline$r$ & دالة * & r.99V & $r 9.01$ & Irk & rq. 21 & 0. & 0.710 & $\vee \wedge$ & الذين مروا بنفى تجارب المشكلة الآخرين \\
\hline$Y$ & غير دالة| & $\cdot \varepsilon \cdot 1$ & $07 . \vee 9$ & $1 \wedge \varepsilon$ & 00.49 & $9 \varepsilon$ & $0 \wedge . \leqslant \leqslant$ & 9. & 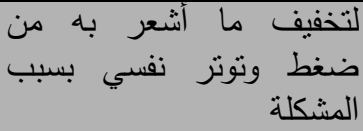 \\
\hline 0 & غير دالة| & $1 . M 1 \varepsilon$ & Y1.T. & V. & 18.70 & $r$. & ro.9V & $\varepsilon$. & لكي أى مشكلاتي سليم لا يُعاني \\
\hline & & & & TY & & $1 \mathrm{~V} \cdot$ & & $10 \leqslant$ & جملة من سئلوا \\
\hline
\end{tabular}


أوضحت نتائج الجدول السابق أن أهم دوافع التماس أولياء الأمور للمعلومات حول

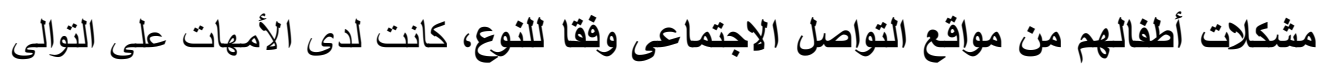

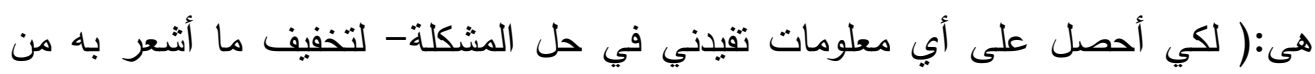

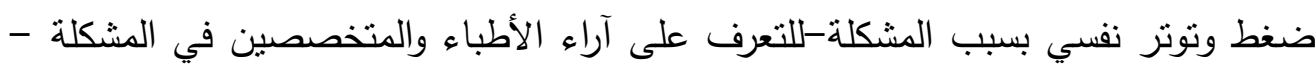

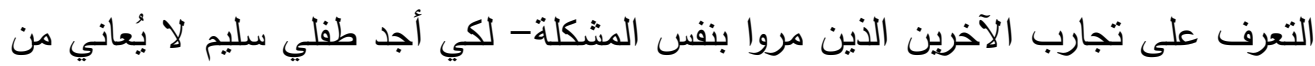

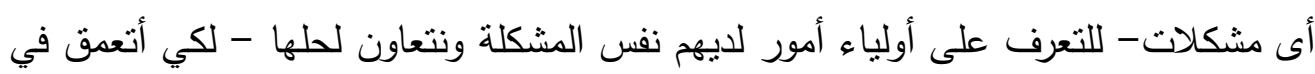

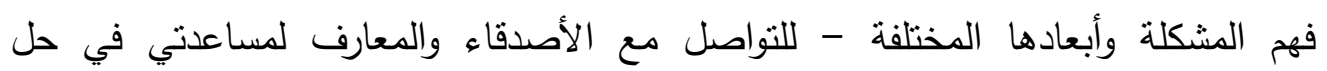

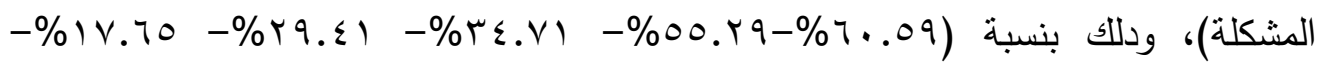

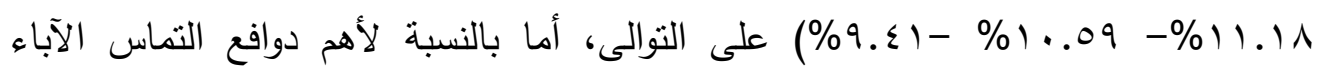

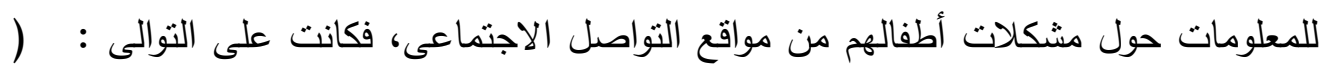

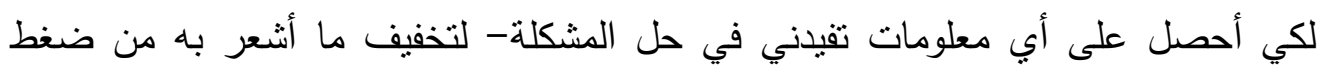
وتوتر نفسي بسبب المشكلة- التعرف على تجارب الآخرين الذين مروا بنفس المشكلة-

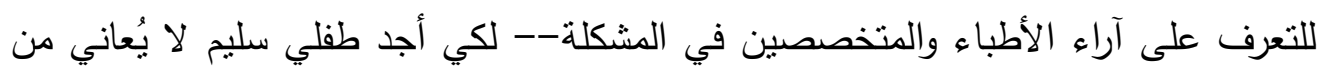
أى مشكلات- لكي أتعمق في فهم المشكلة وأبعادها المختلفة- للتعرف على أولياء أمور لايهم نفس المشكلة ونتعاون لحلها- للتواصل مع الأصدقاء والمعارف لمساعدني في حل المشكلة) ،

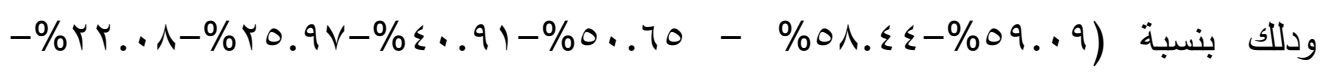

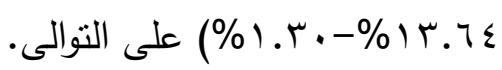

وتوضح نتائج الجدول السابق تثابة دوافع التماس أولياء الأمور من الذكور والإناث

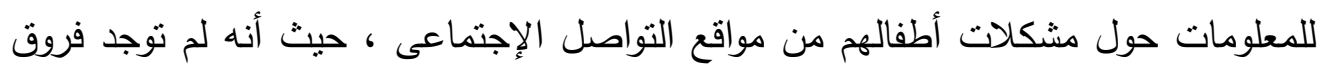

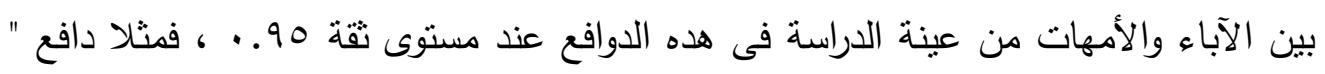

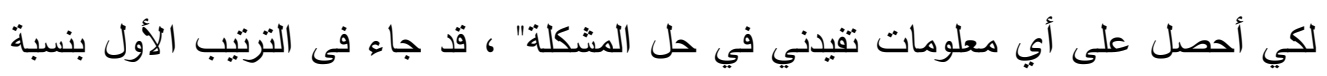

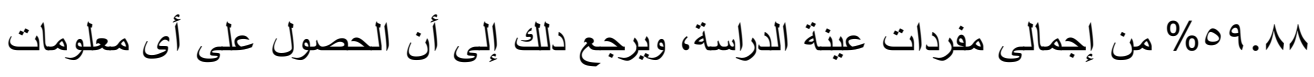

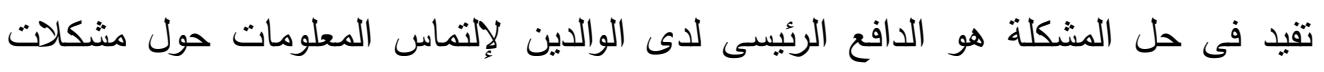

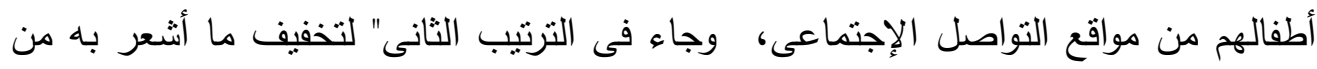

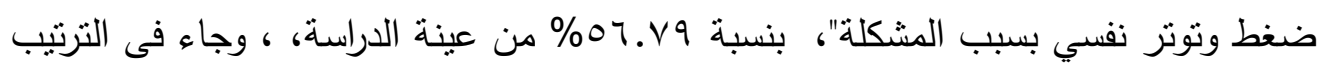

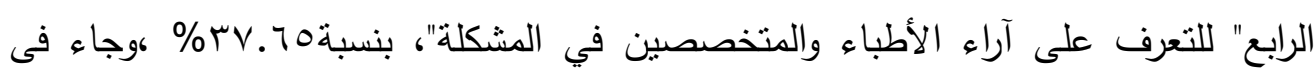

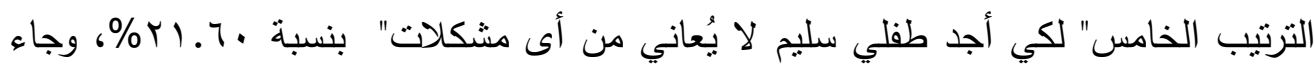


فى الترتيب السابع" للتعرف على أولياء أمور لديهم نفس المشكلة ونتعاون لحلها" بنسبة

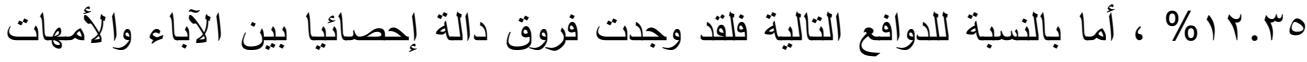

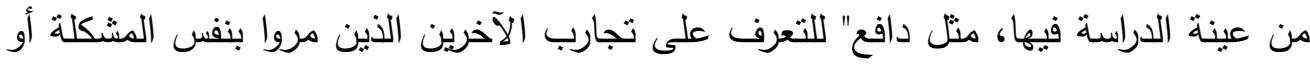

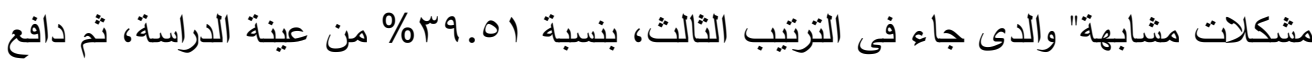

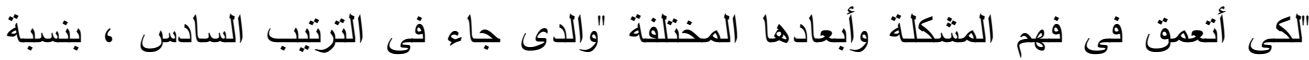

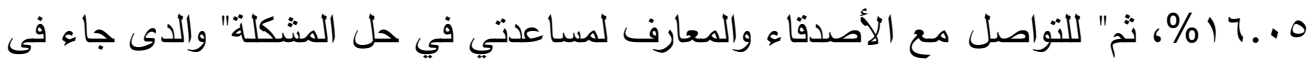

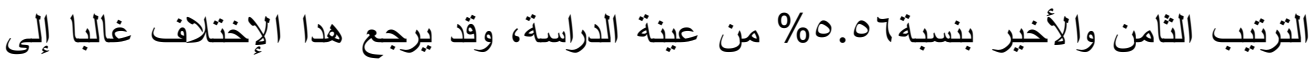
إختلاف الجنس بين المبحوثين مما يؤدى إلى إختلاف الدوافع • צ- أهم مواقع التواصل الاجتماعى التى يستخدمها أولياء الأمور لالتماس المعلومات حول

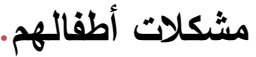
جدول رقم (• () أهم مواقع التواصل الاجتماعى التى يستخمها أولياء الأمور لالتماس المعلومات حول مشكلات أطفالهم وفقا للنوع.

\begin{tabular}{|c|c|c|c|c|c|c|c|c|c|}
\hline \multirow[t]{2}{*}{ ? } & \multirow{2}{*}{ | الدلالة | الد } & \multirow{2}{*}{ قيمة z } & \multicolumn{2}{|c|}{ الإجمالي } & \multicolumn{2}{|c|}{ إناث } & \multicolumn{2}{|c|}{ ذكور } & \multirow[b]{2}{*}{ المواقع } \\
\hline & & & $\%$ & ك) & $\%$ & ك5 & $\%$ & 5) & \\
\hline 0 & | دالة**** & $r . \vee 17$ & r. ro & 91 & rA. Y & 70 & r). $\varepsilon r$ & Tr & |تويتر \\
\hline r & |غير دالة & 1.700 & $\varepsilon 0.71$ & $1 \leqslant 1$ & $\varepsilon \wedge . \Upsilon \leqslant$ & Nr & $\sum Y . \wedge T$ & 77 & جوجل بلس \\
\hline 1 & | دالة**** & r.AVT & $\vee 9 . .1$ & roT & $v \cdot \ldots$ & 119 & 11.97 & ITV & الفيس بوك \\
\hline$\varepsilon$ & دالة & 9.179 & rV. To & $M r$ & $\varepsilon 1 . \vee 7$ & $v_{1}$ & r.וtr & 01 & |وانس أب \\
\hline r & غير دالة & $1 . \cdot \leqslant V$ & $\{r . r)$ & $1 \varepsilon$ & $\varepsilon \varepsilon .1 T$ & vo & $\{r . r)$ & 70 & |ليوتيوب \\
\hline & & & 1 & & IV & & 10 & & جملة من سئلوا \\
\hline
\end{tabular}

توضح بيانات الجدول السابق أهم مواقع التواصل الاجتماعى التى يستخدمها أولياء

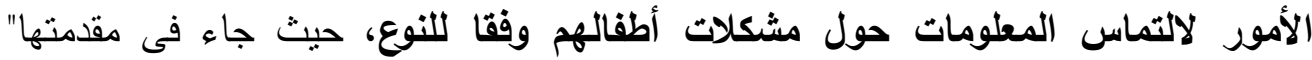

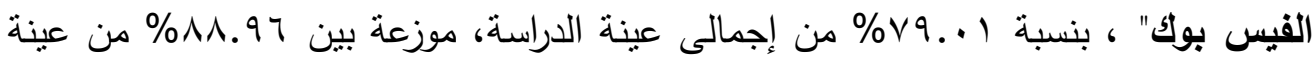

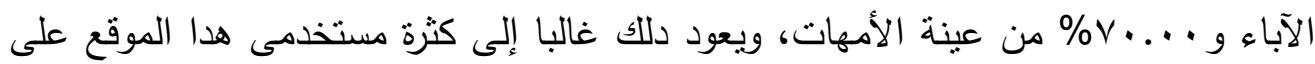

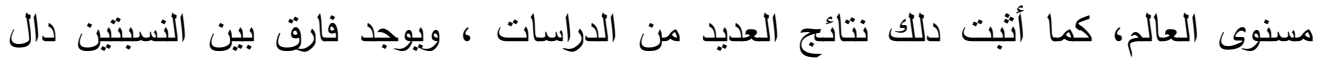

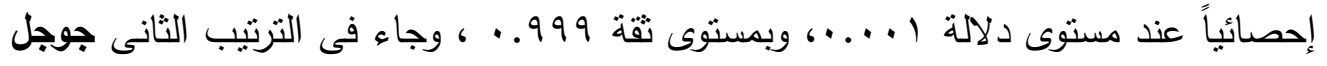

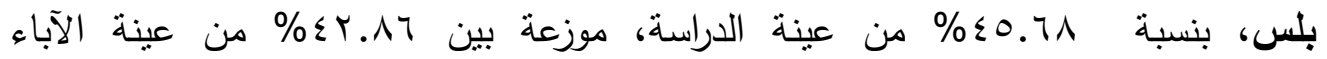

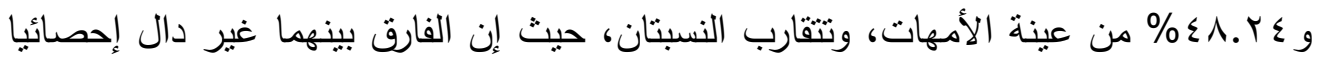

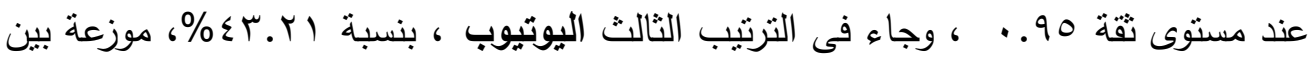




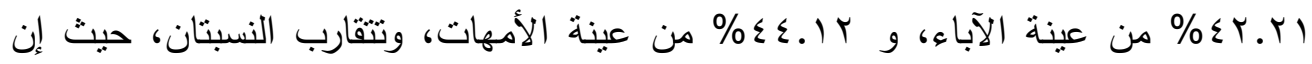

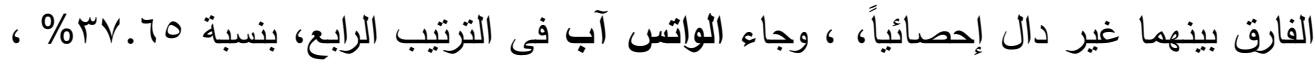

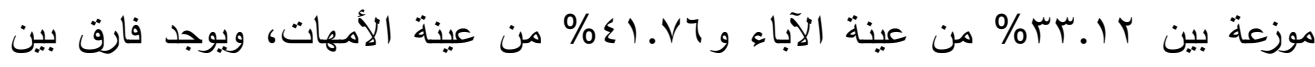

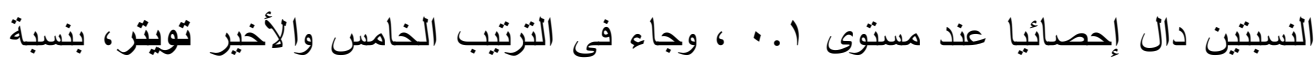

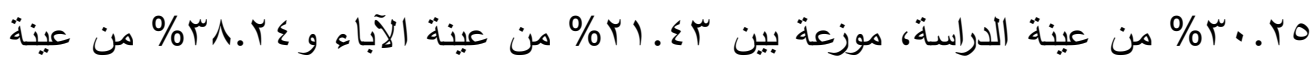

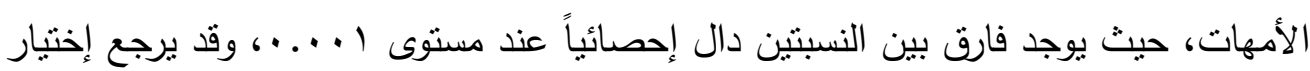

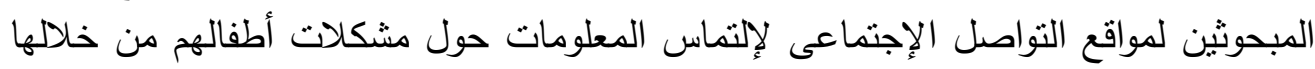

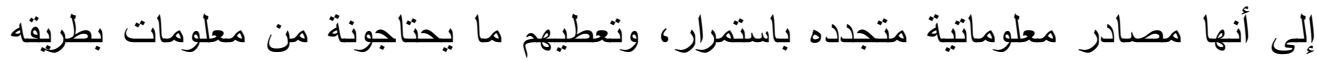

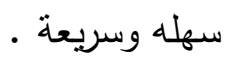

- V أهم الصفحات التى يهتم بها أولياء الأمور بمواقع التواصل الاجتماعى لالتماس المعلومات حول مشكلات أطفالهم.

جدول رقم (1') أهم الصفحات التى يهتم بها أولياء الأمور بمواقع التواصل الاجتماعى لالتماس المعلومات حول مشكلات أطفالهم وفقا للنوع.

\begin{tabular}{|c|c|c|c|c|c|c|c|c|c|}
\hline \multirow[t]{2}{*}{ ? } & \multirow{2}{*}{ | الدلالة } & \multirow{2}{*}{ ق قيمة z } & \multicolumn{2}{|c|}{ الإجمالي } & \multicolumn{2}{|l|}{ إناث } & \multicolumn{2}{|c|}{ ذكور } & \multirow[b]{2}{*}{ الصفحات } \\
\hline & & & $\%$ & 5) & $\%$ & 5) & $\%$ & s) & \\
\hline 7 & دالة & T.rVT & $17 . .0$ & or & $1 . .09$ & 11 & r...A & $r \varepsilon$ & ومقترحات لمشكلات الفراد مهتين بتقاد حلول \\
\hline 1 & | غير دالة & 1.700 & $\leq 0.71$ & $1 \leq 1$ & $\varepsilon \Lambda . Y \leqslant$ & Nr & $\varepsilon r . \wedge T$ & 77 & المتخصصين $\quad$ أطباء $\quad$ الأطفال \\
\hline r & دالة * & r.99V & $r 9.01$ & IrA & rq.ร1 & 0. & $0 . .70$ & $v \wedge$ & مشكلات الطفولة الخبراء والمتخصصين فى \\
\hline$\varepsilon$ & | دالة**** & $r . V 17$ & r..ro & $9 \wedge$ & rA. r & 70 & $r 1 . \leqslant r$ & זr & ومعرفة بمشكلات الصدقاء للديهم وعي \\
\hline$r$ & دالة & 4.179 & rV. 70 & Irr & $\varepsilon 1.87$ & v) & rTr. & 01 & المعنية بالطفولة الهيئات \\
\hline 0 & |غير دالة & $1 . r .7$ & rV.17 & $\wedge \wedge$ & r.. $9 \varepsilon$ & rq & r..Ar & $\varepsilon 9$ & المشكلات آولياء أمور عندهم نفس \\
\hline & & & & 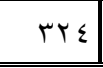 & & $\mathrm{IV} \cdot$ & & $10 \leqslant$ & جملة من سئلوا \\
\hline
\end{tabular}

كثفت نتائج الجدول السابق عن أهم الصفحات التى يهتم بها أولياء الأمور بمواقع

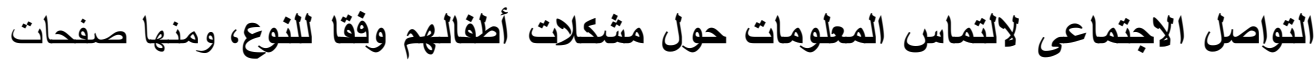
"أطباء الأطفال المتخصصين"، والتى جاءت فى الترتيب الأول لدى كل من الآباء والأمهات

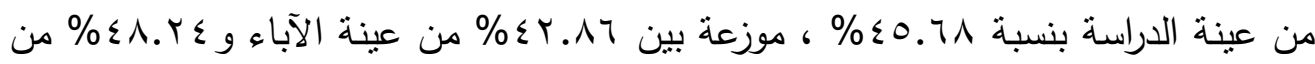

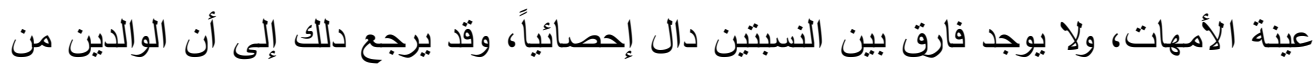

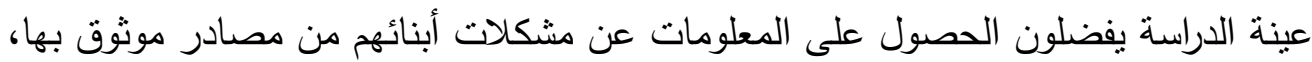


وهم الأطباء المتخصصين فى مشكلات الطفولة ونفسية الأطفال، لأنهم المتخصصين فى تلك ألكاء

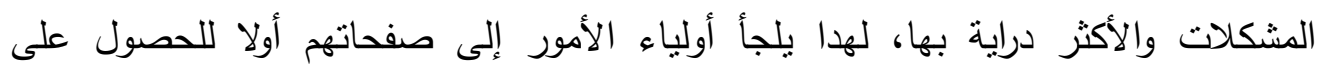
المعلومات حول مشكلات أطفالهم. كما كثفت نتائج الجدول السابق عن وجود فروق دالة إحصائيا بين الآباء والأمهات من فن فئن

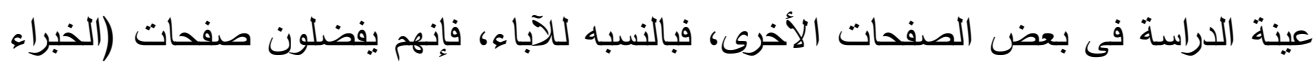
والمتخصصين فى مشكلات الطفولة - أطباء الأطفال المتخصصين - الهيئات والمنظمات المعنية بالطفولة - أولياء أمور عندهم نفس المشكلات - أفراد مهتمين بنقام حلول ومقترحات

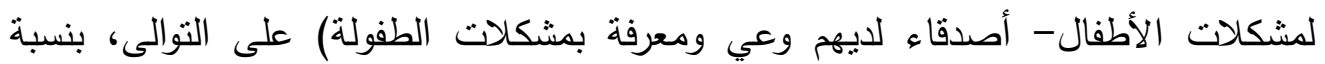
( \% ) ( ) ) ( للأكهات فإنهم يفضلون صفحات (أطباء الأطفال المتخصصين - الهيئات والمنظمات المعنبة

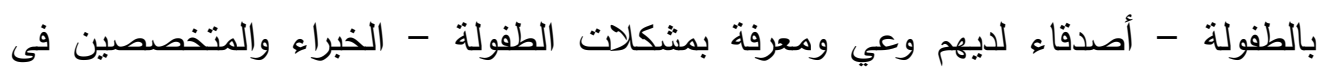
مشكلات الطفولة - أولياء أمور عندهم نف المشكلات - أفراد مهتمين بتقدم حلول

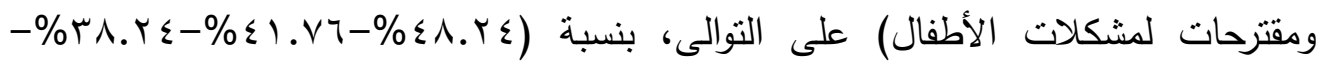

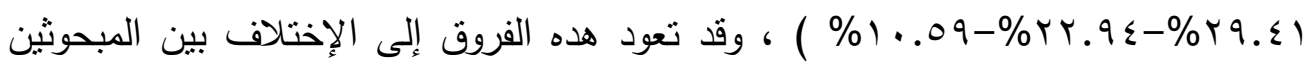

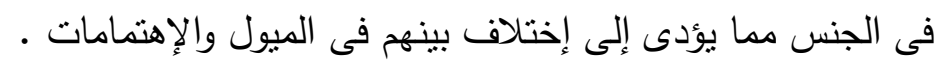

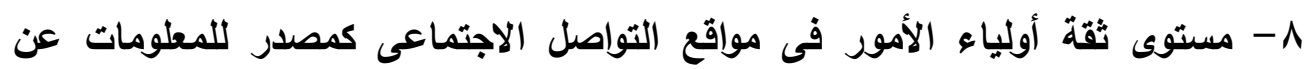

\section{مشكلات أطفالهم وفقا للنوع}

جدول (Y Y ) مستوى تقة أولياء الأمور فى مواقع التواصل الاجتماعى كمصدر للمعلومات عن

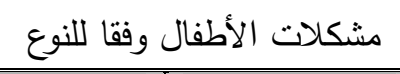

\begin{tabular}{|c|c|c|c|c|c|c|c|}
\hline \multicolumn{2}{|r|}{ الإجمالى } & \multicolumn{2}{|c|}{ إناث } & \multicolumn{2}{|c|}{ ذكور } & \multirow[t]{2}{*}{ النوع } & \multirow[b]{2}{*}{ مستوى التقة } \\
\hline$\%$ & 5 & $\%$ & 5 & $\%$ & ك5 & & \\
\hline 19.19 & IrV & (q. & $7 V$ & ץᄉ.97 & 7. & & مرتفع \\
\hline אז.ז" & 1.1 & א.ס.rr & or & ו.וז" & 01 & & متوسط \\
\hline$r V . \Sigma V$ & 19 & rV..T & $\leq 7$ & rV.9T & $\varepsilon r$ & & منخفض \\
\hline $1 \ldots$ & L & $1 \ldots$ & iv. & $1 \ldots$ & $10 \leqslant$ & & الإجمالي \\
\hline
\end{tabular}

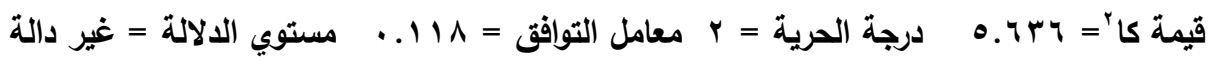

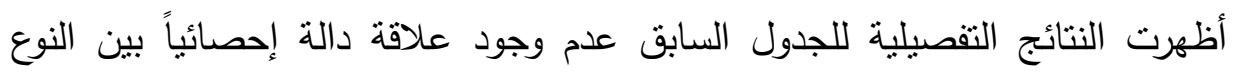
(ذكور - إناث) ومستوى ثقة أولياء الأمور فى مواقع التواصل الاجتماعى كمصدر للمعلومات عن مشكلات الأطفال (مرتفع - متوسط- منخفض) ، حيث بلغت نسبة أولياء الأمور (مرتفعى 
مستوى الثقة) فى صدق وموضوعية مواقع التواصل الاجتماعى كمصدر للمعلومات عن

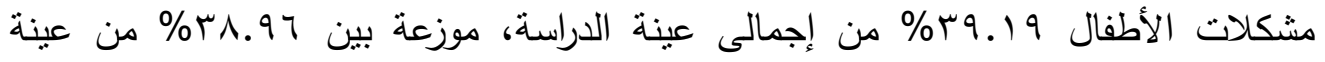

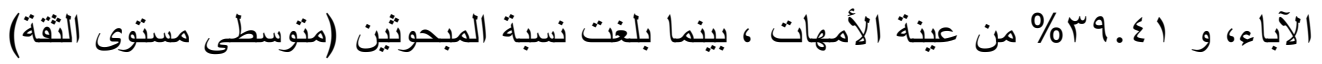

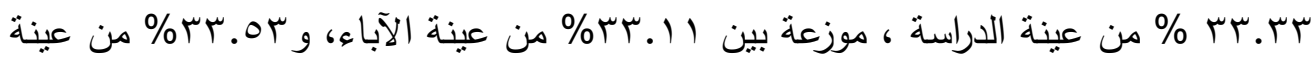

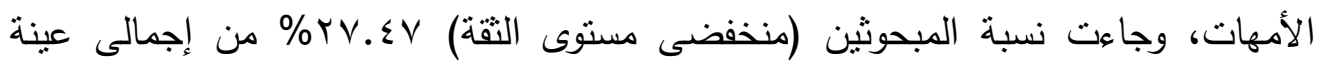

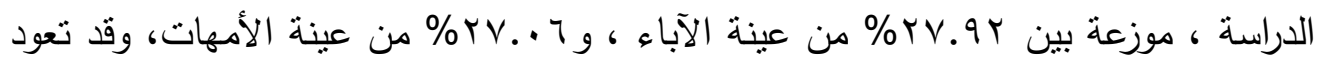

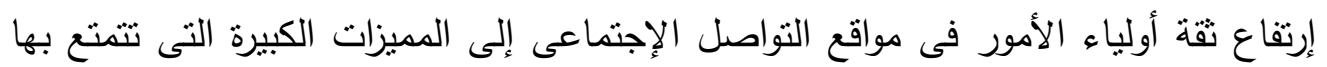
وكثرة المعلومات المتاحة من خلالها فى كافة المجالات، خاصة ما يتعلق منها بمشكلات

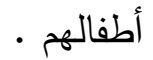

9 - استراتيجيات أولياء الأمور قبل التماس المعلومات حول مشكلات أطفالهم من مواقع التواصل الاجتماعى.

جدول رقم (r ا ) ما يفعله أولياء الأمور قبل التماس المعلومات حول مشكلات أطفالهم من مواقع التواصل الاجتماعى وفقا للنوع.

\begin{tabular}{|c|c|c|c|c|c|c|c|c|c|}
\hline \multirow{2}{*}{ 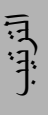 } & \multirow{2}{*}{ 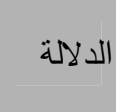 } & \multirow{2}{*}{ | } & \multicolumn{2}{|c|}{ الإجمالي } & \multicolumn{2}{|r|}{ | إناث } & \multicolumn{2}{|r|}{ ذكور } & \multirow[t]{2}{*}{ النوع ل } \\
\hline & & & $\%$ & ك) & $\%$ & 5) & $\%$ & 5) & \\
\hline 1 & غير دالة| & 政 & 07.01 & rol & $\wedge \neg . \leqslant \vee$ & $1 \leq V$ & $V r_{.} \cdot \Lambda$ & 111 & آبحث موقع بشل عشوائي في آكثر \\
\hline r & غير دالة| & $1 . V Y 0$ & $r . .0 \leqslant$ & 149 & $\varepsilon . .09$ & 79 & r^.97 & 7. & 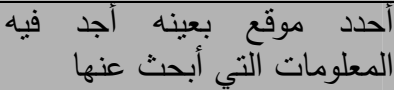 \\
\hline$\varepsilon$ & غير دالة| & $1.7 \mathrm{VV}$ & rT.qT & 1.0 & $r \varepsilon .1 Y$ & $0 \wedge$ & $r . .0 r$ & $\leqslant V$ & أقوم بيحثلة سريع داخل الموقع \\
\hline$r$ & | غير دالة & $1 . \leqslant 99$ & r^... & lor & $0 V . .7$ & $9 V$ & ro.vi & 00 & 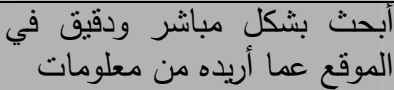 \\
\hline 0 & | غير دالة & $. r \leq V$ & $r \cdot . \wedge V$ & AV & $r v . . T$ & $\Sigma 7$ & r7.7r & $\varepsilon 1$ & والطرح أسئلة وأرسلها ل للأطباء \\
\hline & & & & & & iv. & & $10 \leqslant$ & جملة sن سئلوا \\
\hline
\end{tabular}

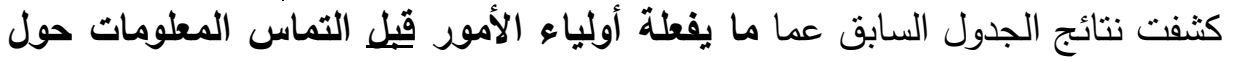

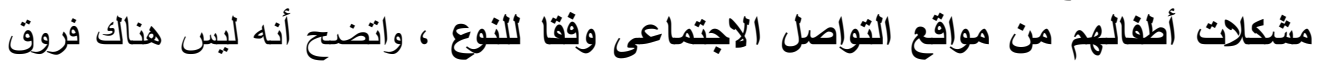

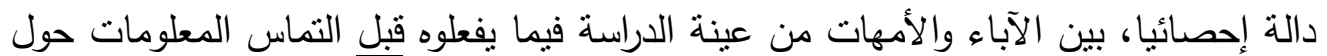

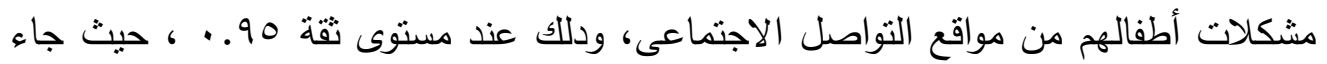

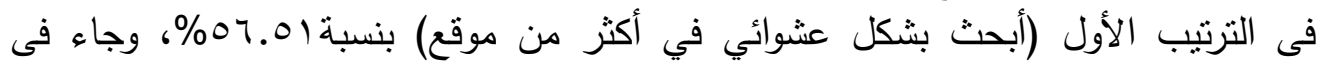

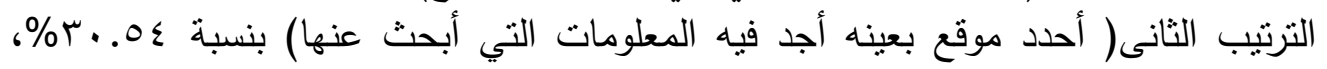


وجاء فى الترتيب الثالث (أبحث بشكل مباشر ودقيق في الموقع عما أريده من معلومات)

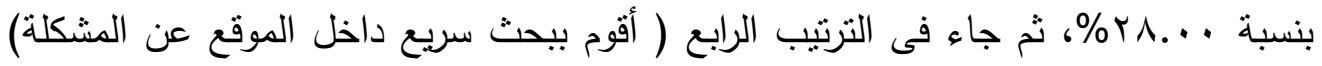

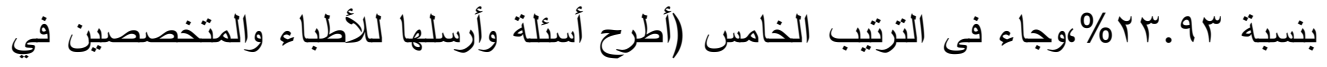

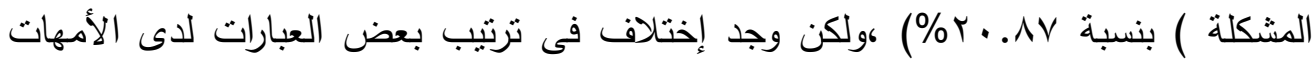

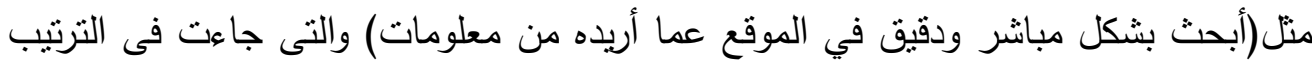

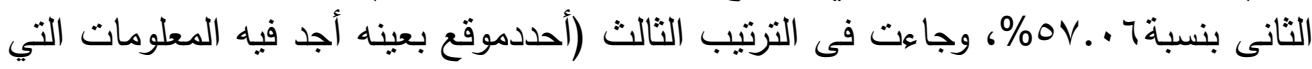

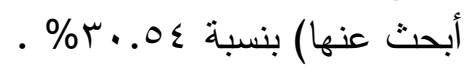

• 1- استراتيجيات أولياء الأمور أثناء التماس المعلومات حول مشكلات أطفالهم من مواقع

\section{التواصل الاجتماعى.}

جدول رقم (ع () ما يفعله أولياء الأمور أثناء التماس المعلومات حول مشكلات أطفالهم من مواقع التواصل الاجتماعى وفقا للنوع.

\begin{tabular}{|c|c|c|c|c|c|c|c|c|c|}
\hline \multirow[t]{2}{*}{ 繁! } & \multirow{2}{*}{ |الدلالة } & \multirow{2}{*}{ قيمة z } & \multicolumn{2}{|c|}{ الإجمالي } & \multicolumn{2}{|c|}{ إناث } & \multicolumn{2}{|c|}{ ذكور } & \multirow{2}{*}{ الاستراتيجيات } \\
\hline & & & $\%$ & ك5 & $\%$ & 5) & $\%$ & 5 & \\
\hline$r$ & غير دالة & $1 . V T_{0}$ & $r V . \leq T$ & 19 & 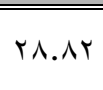 & $\leqslant 9$ & ro.9V & $\varepsilon$. & |قرن المشكلة فقط الموضوعات المكتوبة \\
\hline 1 & دالة * & $r_{.} l \cdot \varepsilon$ & $01.0 \leqslant$ & 178 & $09 . \leqslant 1$ & 1.1 & $\sum Y . \wedge T$ & 77 & |أقراً بسرعة أجزاء مما كتب عن || \\
\hline r & غير دالة & l.Ar. & $\Gamma \varepsilon .0 V$ & 114 & סr.rT & 00 & rv.. I & or & قآقراً معظمة ما كَتب عن المشكلة \\
\hline 0 & دالة * & r.org & $1 . .19$ & זr & ס.r. & ru & V.Vq & IT & |أقرأ كل ما كَتب عن المشكلة كاملأً \\
\hline 7 & غير دالة & $1 . r N 1$ & $V . V Y$ & ro & $9 . .9$ & $1 \varepsilon$ & $T . \leqslant V$ & 11 & أهتماحبة للموضورعات المكتوبة \\
\hline v & غير دالة &. . АTV & 0.10 & IV & 纟.V। & $\wedge$ & $0 . \Lambda \varepsilon$ & 9 & 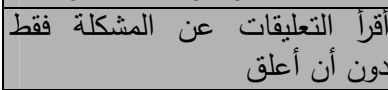 \\
\hline$\wedge$ & غير دالة & 1.17. & T.\&V & $\wedge$ & 1.11 & r & r.q. & 7 & ألآخرين فلى بعض المشكلة المعلومات وآراء \\
\hline$\varepsilon$ & دالة * & r. $r_{1} \leq$ & $|\Lambda . r|$ & 09 & 10.19 & rT & $r$ r. & r & 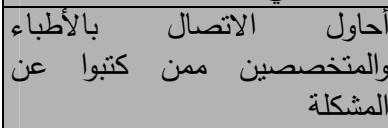 \\
\hline & & & & & $1 \mathrm{~V}$ & & 10 & & جملة من سئلوا \\
\hline
\end{tabular}

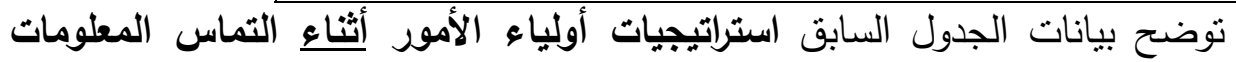

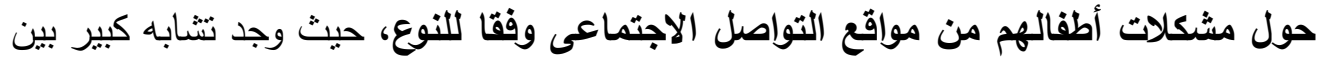

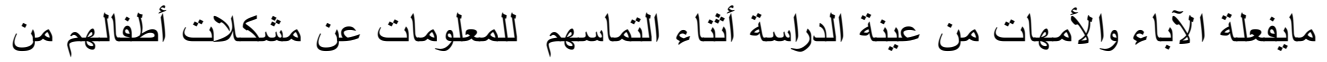

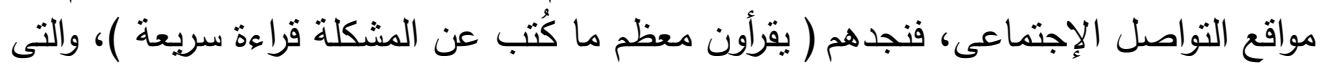

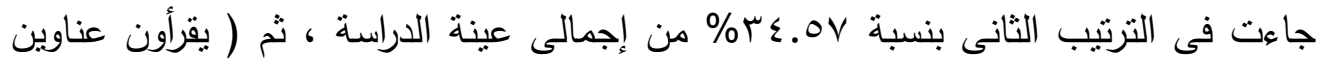

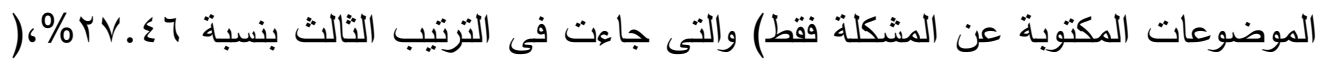
ويهتمون بالصور والفيديوهات المصاحبة للموضوعات المكتوبة)، والتى جاءت في في في الترتيب 


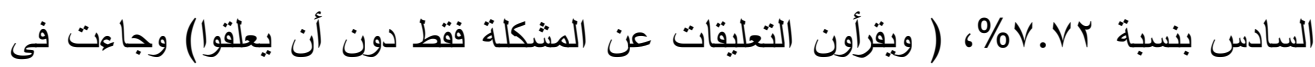

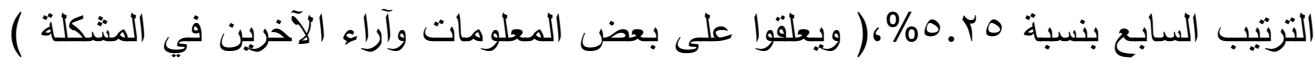

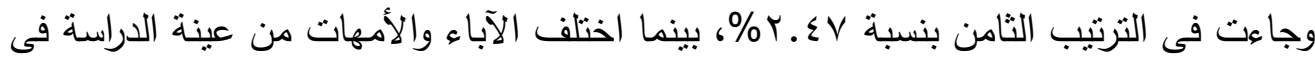

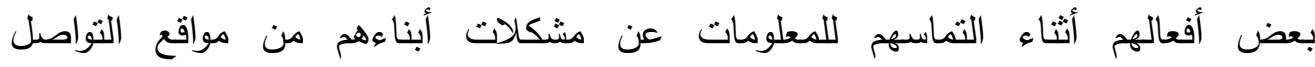

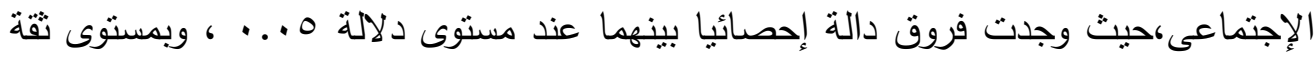

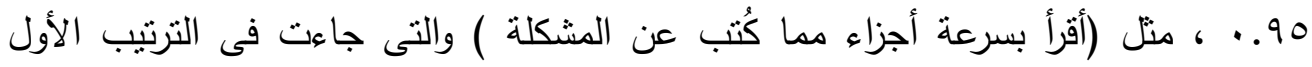

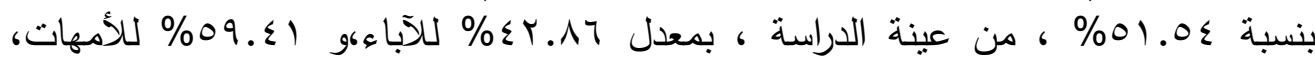

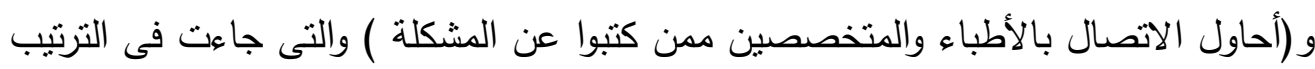

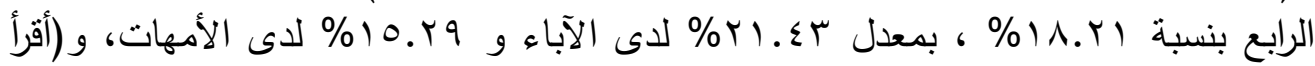

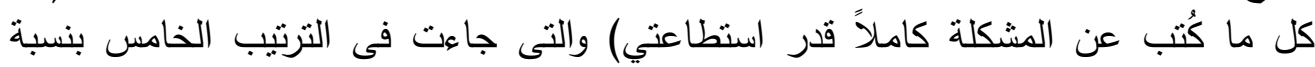

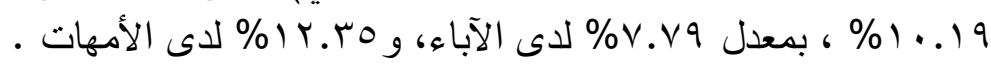

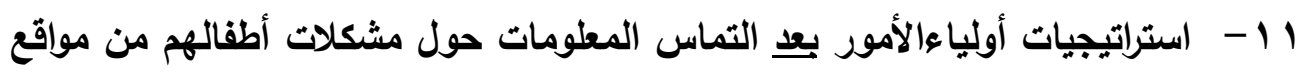
التواصل الاجتماعى. جدول رقم (0 1 ) ما يفعله أولياء الأمور بعد التماس المعلومات حول مشكلات أطفالهم من مواقع التواصل

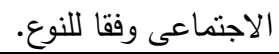

\begin{tabular}{|c|c|c|c|c|c|c|c|c|c|}
\hline \multirow{2}{*}{ 蛹 } & \multirow{2}{*}{ الد الالة الد } & \multirow{2}{*}{ قيمة z } & \multicolumn{2}{|c|}{ الإجمالي } & \multicolumn{2}{|r|}{ إناث } & \multicolumn{2}{|r|}{ ذكور } & \multirow[b]{2}{*}{ الاستجابة } \\
\hline & & & $\%$ & 5) & $\%$ & 5) & $\%$ & 5) & \\
\hline r & غير دالة & $1 . r \wedge 7$ & rV.. s & ir. & $\varepsilon 1.11$ & $v \cdot$ & 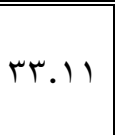 & 01 & 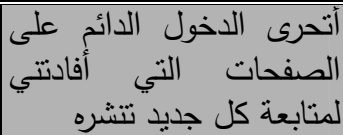 \\
\hline 0 & غير دالة & I.r. & YT. $\leqslant T$ & V7 & Y૫. $\leqslant V$ & $\leqslant 0$ & $r . .1 T$ & r & أتتاقشت مليه من الآخرين فيمات \\
\hline$\varepsilon$ & دالة* & T.ITY & YA.. 9 & 91 & $r \varepsilon . V$. & $\leqslant r$ & TI.AI & $\varepsilon 9$ & أبدى أفادنتي فقط بالمعلومات \\
\hline 1 & دالة* & r.MTI & $\leqslant r .9$. & 149 & $0 . .09$ & NT & $r \varepsilon . \varepsilon r$ & or & 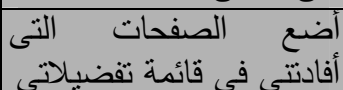 \\
\hline r & غير دالة & דואח. & r... & $1 \cdot \varepsilon$ & 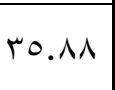 & 71 & $r V .9 T$ & $\varepsilon r$ & أعلقت على المعلومات التى \\
\hline 7 & غير دالة & $. r \leq T$ & Y1.7. & $\vee$. & rT.Or & $\varepsilon$. & $1 \wedge . \wedge r$ & rq & 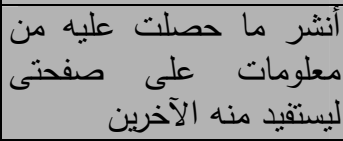 \\
\hline$\checkmark$ & غير دالة & $\cdot . \wedge \cdot 1$ & 18.9. & 01 & Y.11 & ru & $1 \varepsilon .49$ & rr & 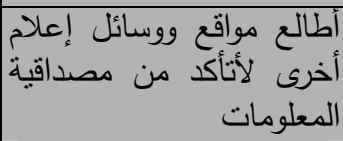 \\
\hline & & & & TrE & & IV. & & $10 \leqslant$ & جملة من سئلوا \\
\hline
\end{tabular}

توضح نتائج الجدول السابق استراتيجيات أولياء الأمور بعد التماس المعاس المعلومات حول

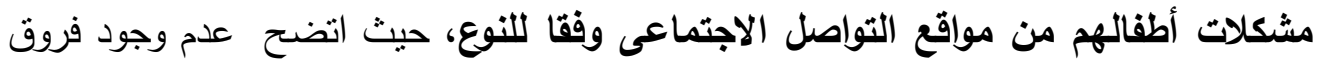


دالة إحصائيا بينهم فى بعض الأفعال، منل : (أضع الصفحات التي أفادتني في قائمة

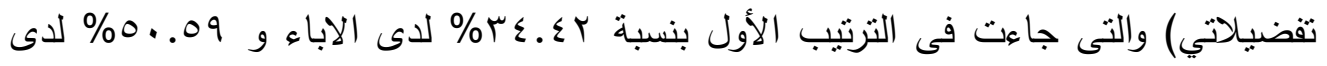

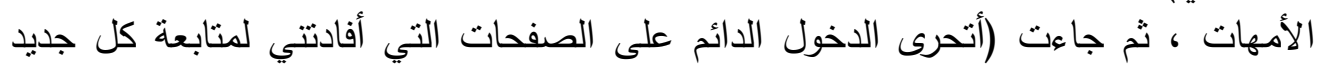

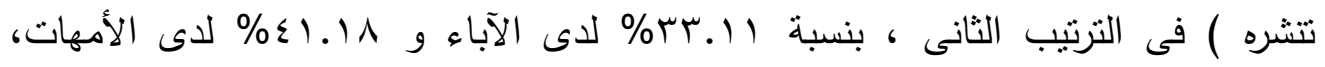

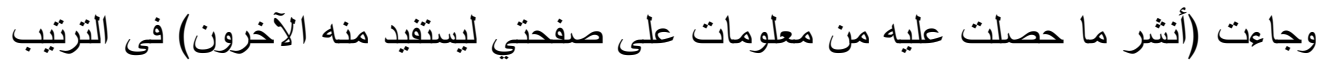

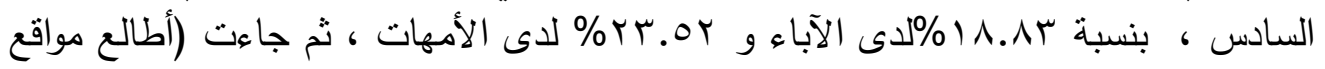

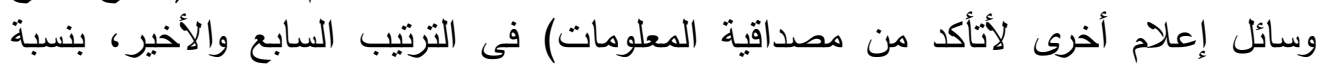

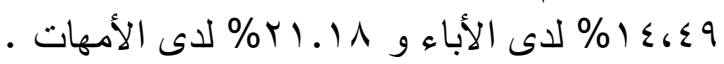

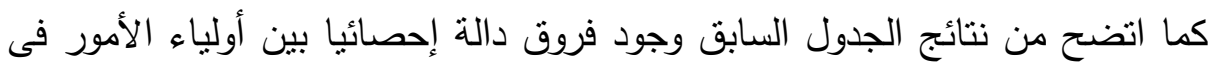

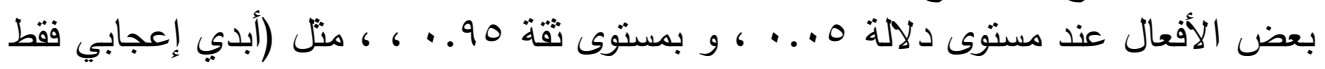

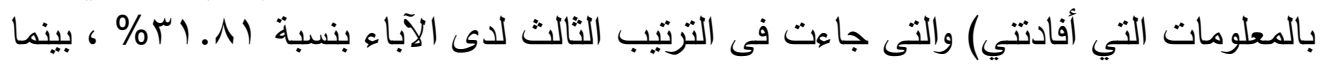

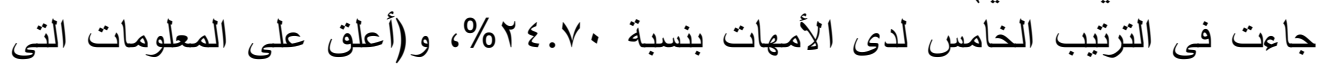

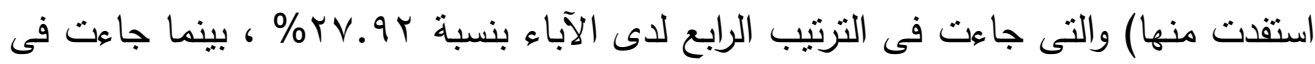

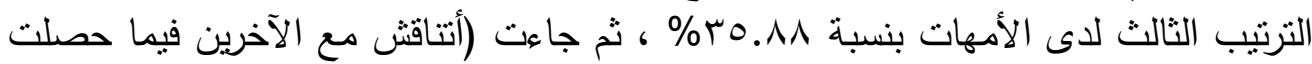

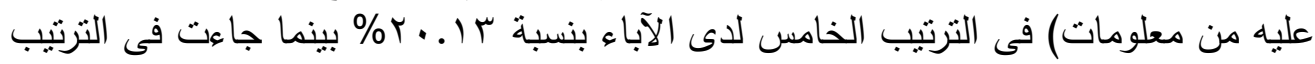

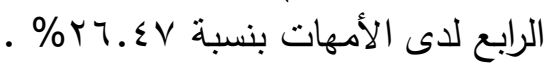
r ا-مدى استفادة أولياء الأمور من مواقع التواصل الأبل الاجتماعى كمصدر للمعلومات عن مشكلات أطفالهم جدول (7 7 ) مدى استفادة أولياء الأمور من مواقع التواصل الاجتماعى كمصدر للمعلومات عن مشكلات أطفالهم وفقا للنوع التواج

\begin{tabular}{|c|c|c|c|c|c|c|}
\hline \multicolumn{2}{|c|}{ الإجمالى } & \multicolumn{2}{|c|}{ إناث } & \multicolumn{2}{|c|}{ ذكور } & النوع \\
\hline$\%$ & 5) & $\%$ & 5) & $\%$ & 5 & معدل الاستفادة \\
\hline $00 . \wedge 7$ & 111 & $0 \leqslant . V 1$ & $9 \pi$ & ov.1s & $\Lambda \wedge$ & مرتفع \\
\hline rV.97 & $M T$ & EY.TO & $V Y$ & r.וT & 01 & متوسط \\
\hline $7.1 \mathrm{~V}$ & $r$. & Y. $9 \leq$ & 0 & $9 . \vee \leqslant$ & 10 & منخفض \\
\hline $1 \ldots$ & TrE & $1 \ldots$ & IV. & $1 \ldots$ & $10 \xi$ & الإجمالى \\
\hline
\end{tabular}

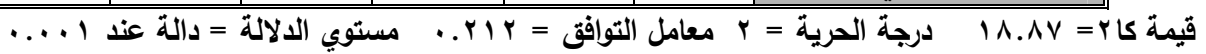

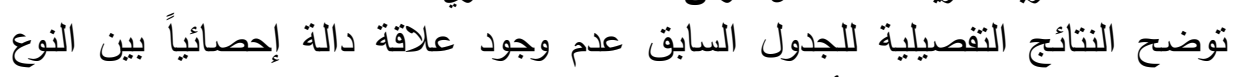

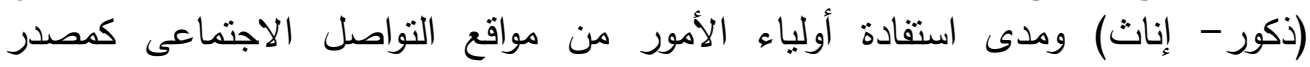

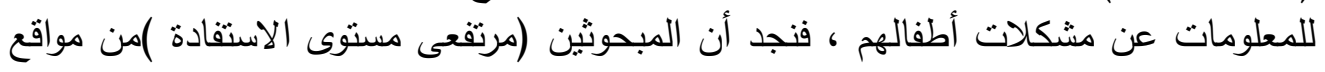

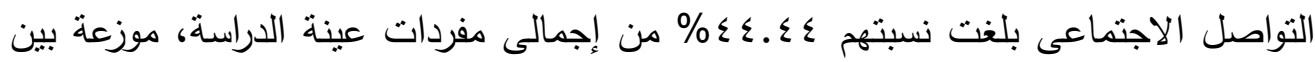

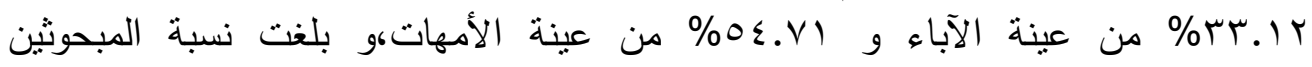

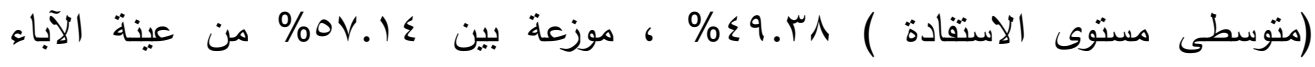
و وr.r\% من عينة الأمهات، وجاءت نسبة المبحوثين (منخفضى مستوى الاستفادة) 


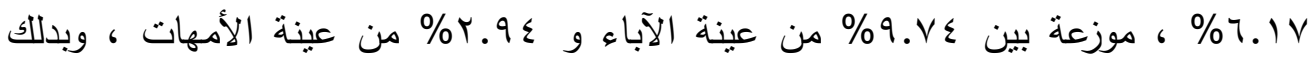
نلاحظ أن أكثر من نصف عينة الدراسة من كلا الجنسين مرتفعى الإستفاده من مواقع الأنع

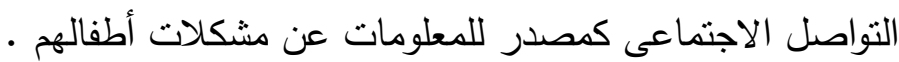

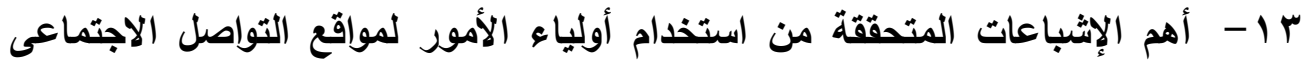
لالتماس المعلومات حول مشكلات أطفالهم.

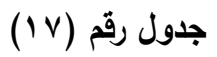

أهم الإثباعات المتحققة لأولياء الأمور من استخدام مواقع التواصل الاجتماعى_لالتماس المطلومات حول مشكلات أطفالهم وفقام للنوع.

\begin{tabular}{|c|c|c|c|c|c|c|c|c|c|}
\hline \multirow{2}{*}{ 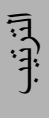 } & \multirow{2}{*}{ 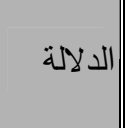 } & \multirow{2}{*}{ قيمة Z } & \multicolumn{2}{|c|}{ الإجمالي } & \multicolumn{2}{|c|}{ إناث } & \multicolumn{2}{|c|}{ ذكور } & \multirow{2}{*}{ الاستجابة } \\
\hline & & & $\%$ & 5) & $\%$ & 5) & $\%$ & s) & \\
\hline r & | غير دالة & $\cdot \varepsilon \wedge 1$ & rV.. $\varepsilon$ & Ir. & $r . \Sigma V$ & Tr & TV.TT & $0 \wedge$ & تخلصيت من من من الألم بسبب معاناة \\
\hline 0 & | غير دالة & .171 & Yr. $\leq T$ & $V 4$ & rT.OT & $\varepsilon$. & rr.r人 & ry & 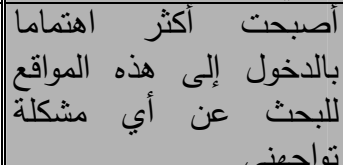 \\
\hline$\varepsilon$ & |غير دالة & $1.09 \mathrm{~V}$ & rA.. 9 & 91 & $r \leq . V \mid$ & $\varepsilon r$ & M. IT & $\leqslant 9$ & وفي الأطباء لي المرصنة للنقاش \\
\hline 1 & |غير دالة & $1.1 \mathrm{rA}$ & $\varepsilon r .9$. & 1149 & $\varepsilon . .09$ & 79 & $\leqslant 0 . \leqslant 0$ & $V \cdot$ & |أفادتتي في حلى المشكلة معلومات | على \\
\hline$r$ & | غير دالة & $\cdot .7 \cdot r$ & r... & $1 \cdot \varepsilon$ & 1.11 & or & Tr.וT & 01 & 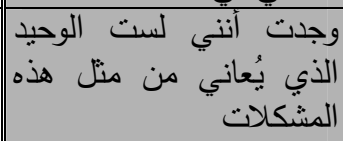 \\
\hline 7 & | غير دالة & $.1 \leq 0$ & Y1.7. & $\vee \cdot$ & Tr.MO & rᄉ & $r \cdot . \vee \wedge$ & rr & 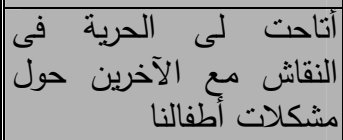 \\
\hline$\wedge$ & | غير دالة & . & 18.9. & 01 & 18.70 & $r$. & 11.11 & rᄉ & 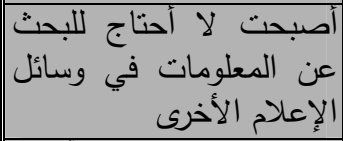 \\
\hline V & | غير دالة & $1 . .1 r$ & 1A.Ar & 71 & $1 V . .7$ & $r q$ & $r \cdot . \vee \wedge$ & r. & أمور لديهم نفس المشات مع أولياء \\
\hline & & & 1 & & $i_{r}$ & & 10 & & جملة من سئلوا \\
\hline
\end{tabular}

توضح بيانات الجدول السابق أهم الإثباعات المتحققة من استخدام أولياء الأمور لمواقع

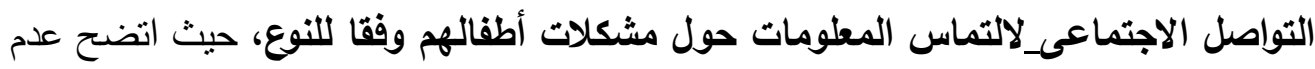

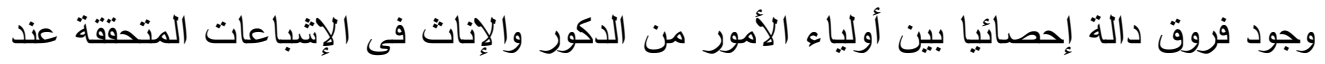

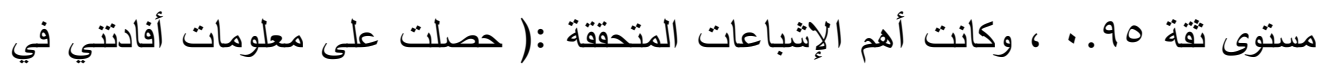




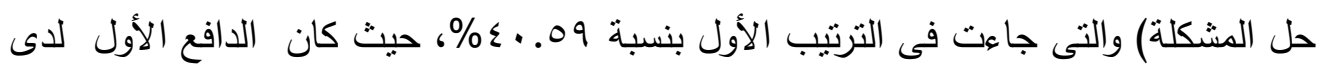

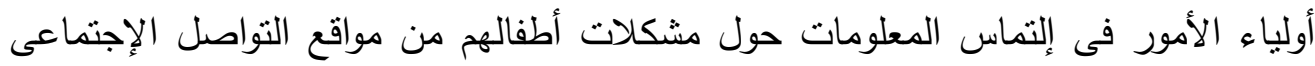

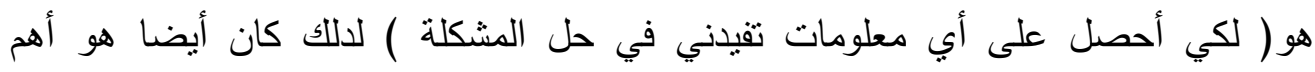

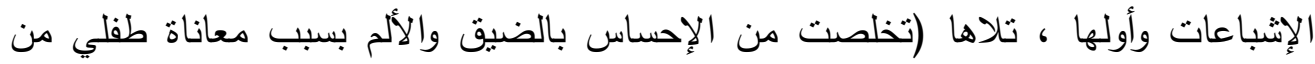

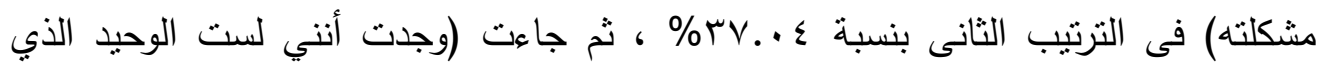

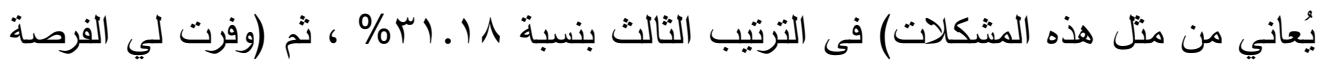

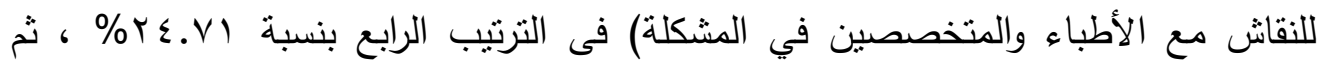

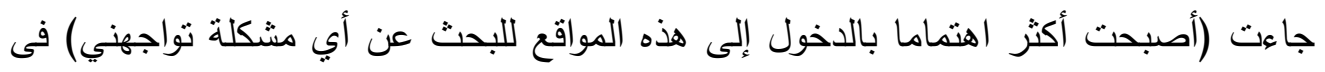

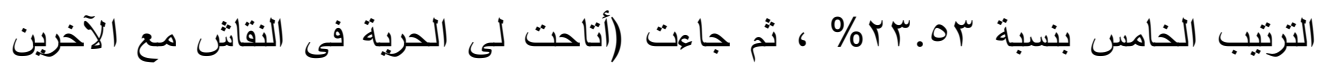

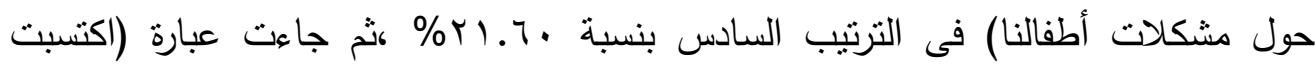

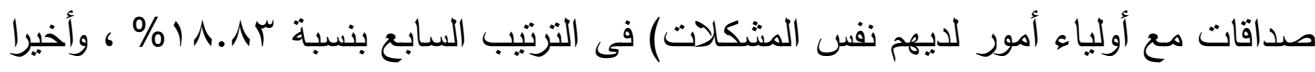
جاءت (أصبحت لا أحتاج للبحث عن المعلومات في وسائل الإعلام الأخرى) فى الترتيب

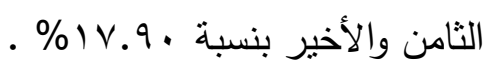

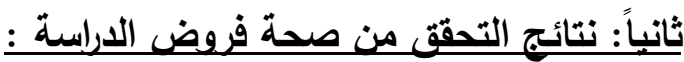
الفرض الأول: توحد علاقة ارتباطية موحبة ودالة إحصائباً بين مستوى استخدام أولياء الأمور للإنترنت ومستوى استخدامهي مواقع التواصل الاجتماعى.

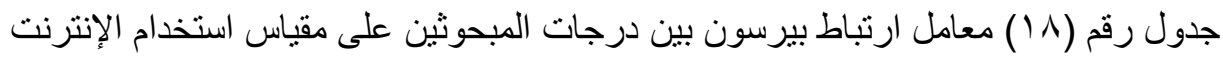

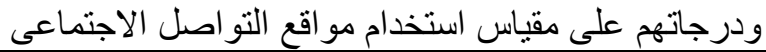

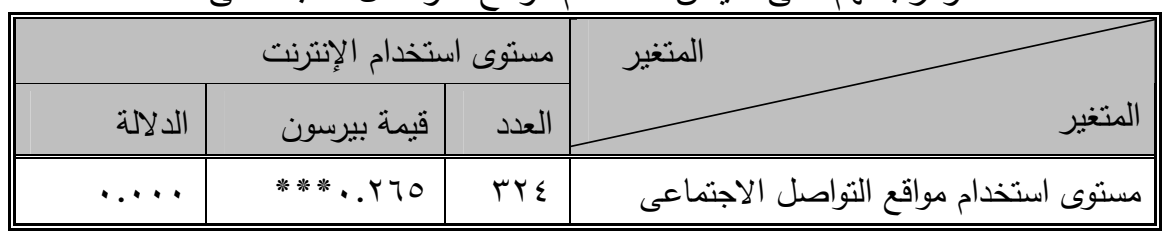

يتضح من بيانات الجدول السابق باستخدام معامل ارتباط بيرسون وجود علاقة ارتباطيه

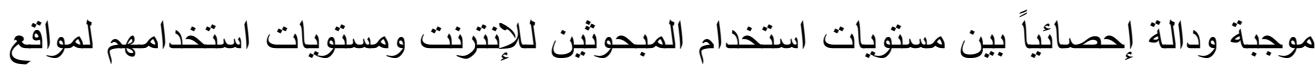

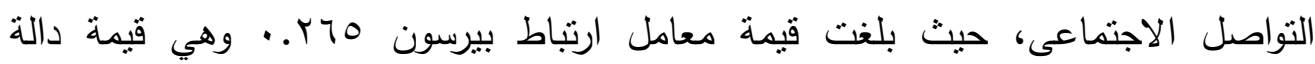

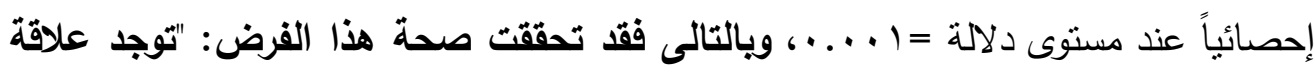
ارتباطية موجبة ودالة إحصائياً بين مستوى استخدام اولياء الأمور للإنترنت ومستوى دألئ

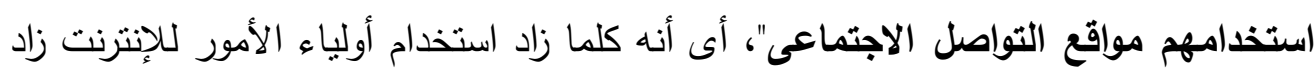
استخدامهم لمواقع التواصل الاجتماعى. 
الفرض الثانى: توجد علاقة ارتباطية موحية ودالة إحصائباً بين مستوى استخدام أولياء الأموي

لمواقع التواصل الاجتماعى ومستوى التماسيه للمعلومات عن مشكلات أطفالهيه من خلالهيا.

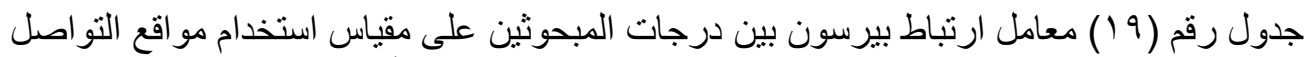

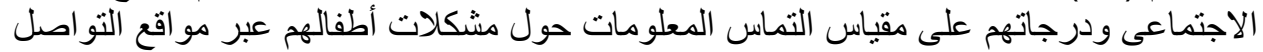
الاجتماعى المعات جون

\begin{tabular}{|c|c|c|c|c|}
\hline \multicolumn{3}{|c|}{ مستوى استخدام مواقع التواصل الاجتماعى } & \multirow{2}{*}{\multicolumn{2}{|c|}{ المتغير }} \\
\hline 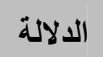 & قيمة بيرسون & 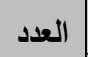 & & \\
\hline$\ldots \ldots$ & $* * *$. r r^ & rrs & المعلومات حول مشكلات الأطفال & مستوى التماس \\
\hline
\end{tabular}

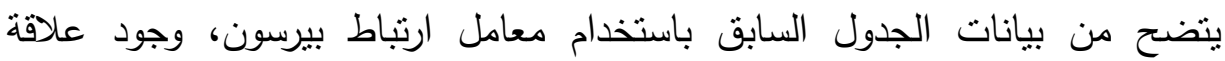

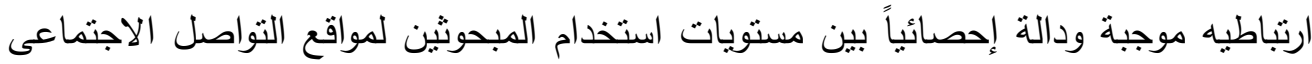

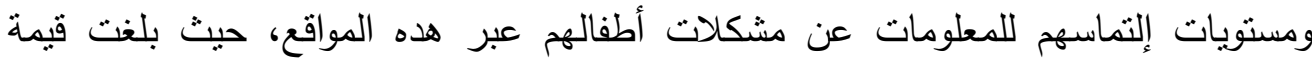

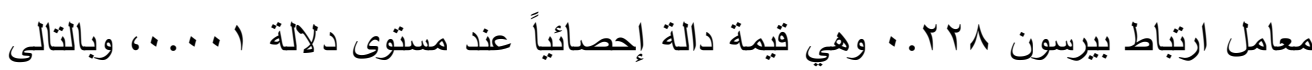

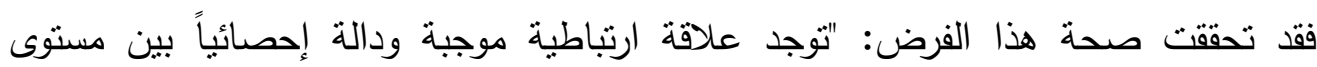
استخدام المبحوثين لمواقع التواصل الاجتماعى ومستوى التماسهم للمعلومات حول مشكلات

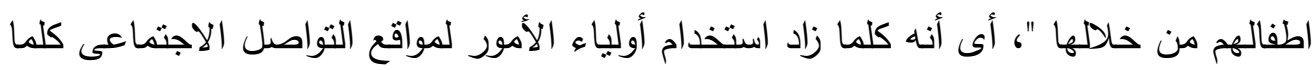

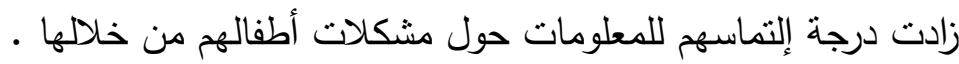
الفرض الثالث: توحد علاقة ارتباطية موحبة ودالة إحصائياً بين دوافع التماس أولياء الأمور للمعلومات حول مشكلات أطقالهم من مواقع التواصل الاجتماعى ومستوى التماس

المطلومات لايهـ. جدول رقم (• (Y) معامل ارتباط بيرسون بين درجات المبحوثين على مقياس دوافع التماس المعلومات

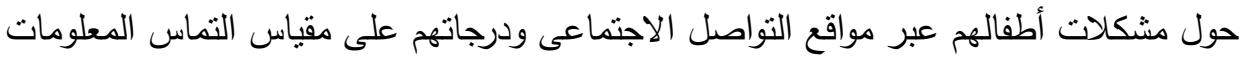

\begin{tabular}{|c|c|c|c|}
\hline \multicolumn{3}{|c|}{ دوافع التماس المعلومات حول مشكلات الأطفال } & \multirow[t]{2}{*}{ 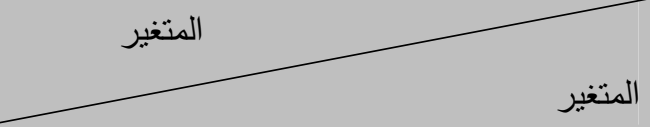 } \\
\hline 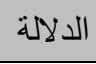 & قيمة بيرسون & 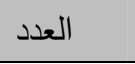 & \\
\hline$\cdots \cdots$ & $* * * \cdot r \cdot r$ & rT & مستوى التماس المعلومات حول مشكلات الأطفال \\
\hline
\end{tabular}

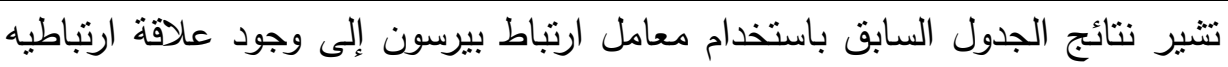

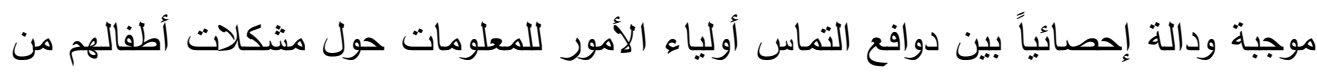

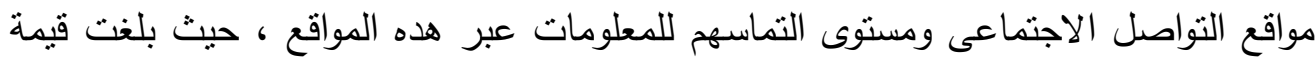

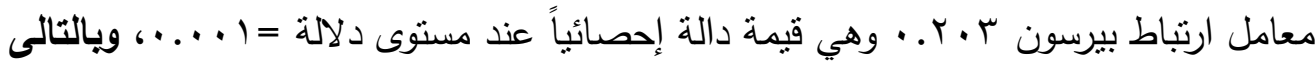

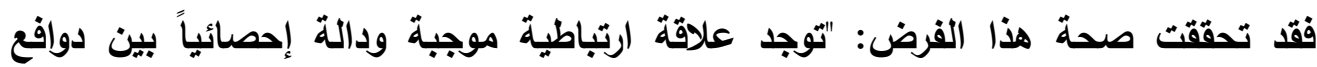

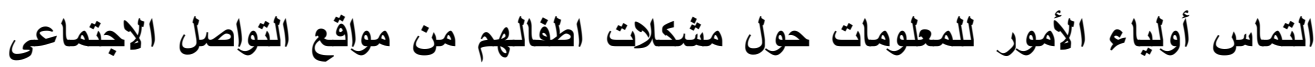


ومستوى التماس المعلومات لايهم "، أى أنه كلما زادت دوافع التماس أولياء الأمور

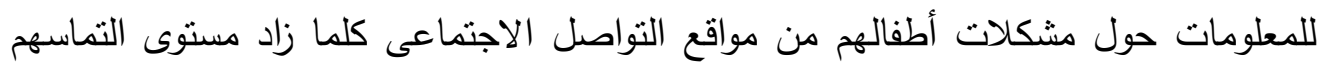

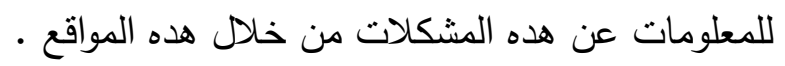
الفرض الرايع: :" توجد فروق ذات دلالة إحصائبة بين متوسطات درجات هات أولياء الأمور على

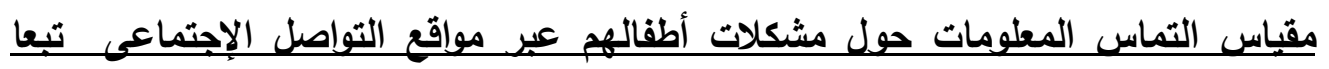

\section{لاختلاف مستويات ثقتهم في هده المواقع كمصدر للمطلومات .}

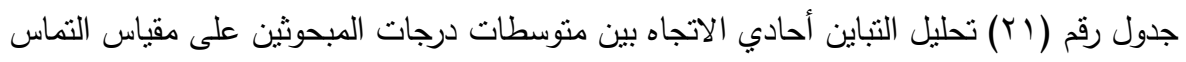

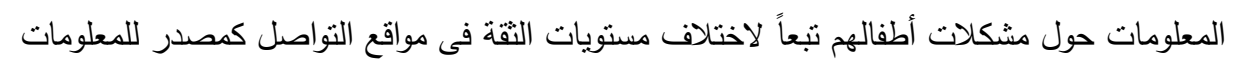

\begin{tabular}{|c|c|c|c|c|c|}
\hline الدلالة & قيمة ف & متوسط مجموع & درجة & المربعات & مصدر التباين \\
\hline \multirow{3}{*}{ دالة** * } & \multirow{3}{*}{ V.01T } & 1. & $r$ & r. $9 \wedge 0$ & بين المجموعات \\
\hline & & .199 & l & & داخل المجموعات \\
\hline & & & מצr & 77.80. & \\
\hline
\end{tabular}

توضح بيانات الجدول السابق وجود فروق ذات دلالة إحصائية بين مجموعات أولياء

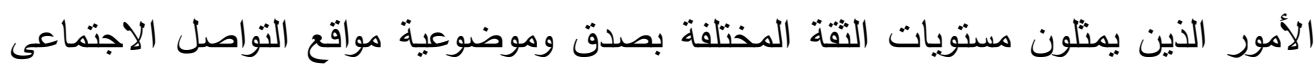

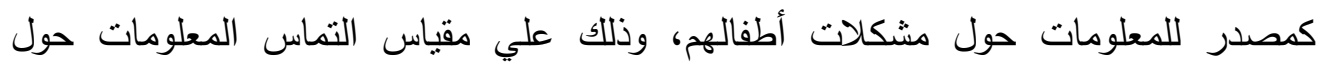

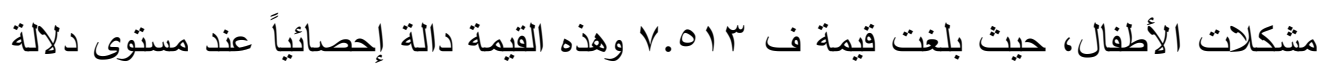

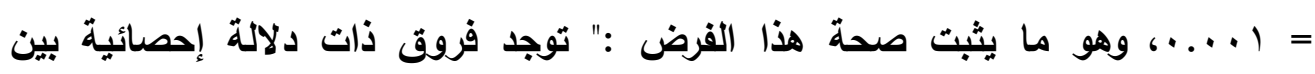

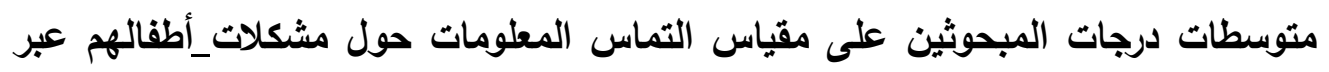

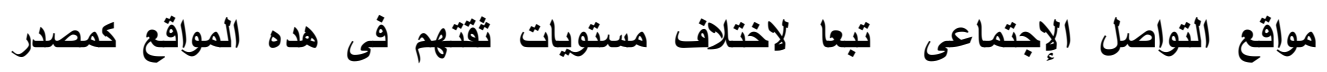

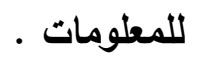

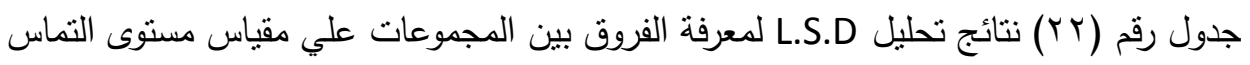
المعلومات حول مشكلات الأطفال

\begin{tabular}{|c|c|c|c|c|}
\hline المتوسط & منخفض & متوسط & مرنقع & المجموعات \\
\hline r.rqr & & & - & مرتفع \\
\hline Y.171 & & - & ***..rMrI & متوسط \\
\hline$r . .$. & - &. .17 .1 & $* * . . \Upsilon q ५ q$ & منخفض \\
\hline
\end{tabular}

ولمعرفة مصدر التباين للفروق بين المتوسطات الحسابية لمجموعات المبحوثين أجرى الاختبار البعدي L.S.D بطريقة أقل فرق معنوي ، حيث اتضح أن هناك اختلافًا بين المبحوثين 
منخفضى مستوى الثقة بصدق وموضوعية مواقع التواصل الاجتماعى، والمبحوثين مرتفعى

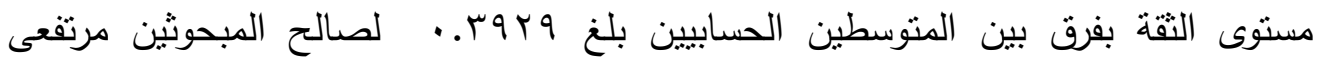

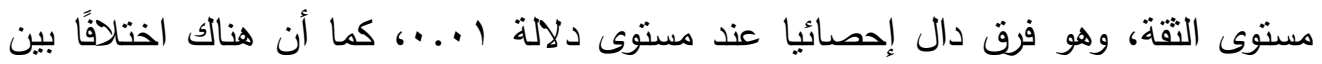
المبحوثين متوسطى مستوى الثقة ، والمبحوثين مرتفحى مستوى الثقة بفرق بين المتوسطين

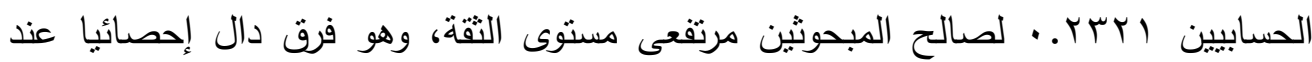

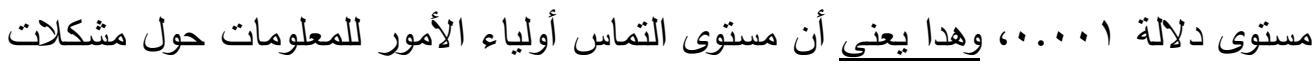

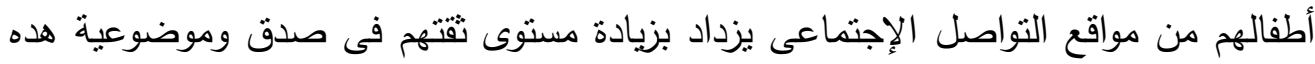
المواقع كمصدر للمعلومات عن هده المشكلات، ويقل بانخفاض مستوى ثقتهم فيها. الفرض الخامس:. توجد فروق ذات دلالة إحصائية بين متوسطات درحات أولياء الأمور على مقياس الإشباعات المتحققة من التماسهم للمعلومات حول مشكلات أطفالهه من مواقع

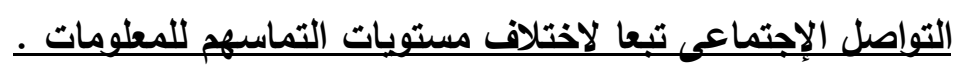
جدول رقم (rT) تحليل التباين أحادي الاتجاه بين متوسطات درجات المبحوثين على مقياس الاثشباعات

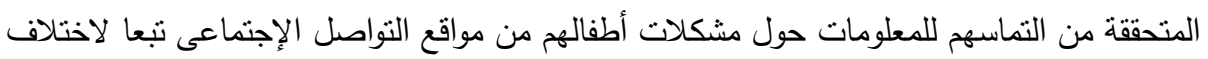
مستويات التماس المعلومات لديهم

\begin{tabular}{|c|c|c|c|c|c|}
\hline الدلالة & قيمة ف & متوسط مجموع المربعات & درجة & المربعوعات & |مصدر التباين \\
\hline \multirow{3}{*}{ دالة*** } & \multirow{3}{*}{$9 . . \leqslant 0$} & $\varepsilon . \cdot r$. & r & $1 . .09$ & بين المجموعات \\
\hline & & •. $\leqslant 77$ & Tr & $1 \leqslant r . .1 r$ & داخل المجموعات \\
\hline & & & אYr & $101 . .81$ & |المجموع \\
\hline
\end{tabular}

تدل بيانات الجدول السابق على وجود فروق ذات دلالة إحصائية بين مجموعات

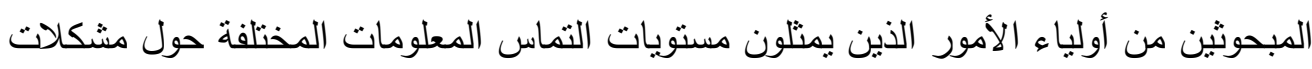
الأطفال، وذلك علي مقياس الإثباعات المتحققة من استخدام مواقع التواصل الاجتماعى لإنى

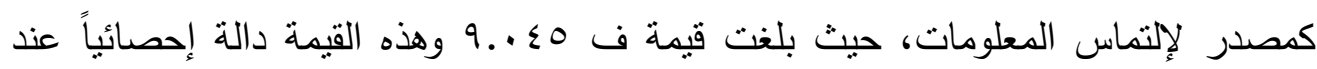
مستوى دلاله ا ..... وهوما يثبت صحة هذا الفرض: " توجد فروق ذات دلالة إحصائية بين متوسطات درجات المبحوثين على مقياس الإشباعات المتحققة من التماسهم للمعلومات حول مشكلات أطفالهم من مواقع التواصل الإجتماعى تبعا لاختلاف مستويات التماسهر ملتهن

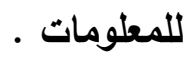


جدول (ع Y) نتائج تحليل L.S.D لمعرفة الفروق بين المجموعات علي مقياس الإثباعات المتحققة من استخدام مواقع التواصل الاجتماعى لمعنى

\begin{tabular}{|c|c|c|c|c|}
\hline الكتوسط & منخفض & متوسط & مرتفع & المجموعات \\
\hline r.rTA & & & - & مرتفع \\
\hline 1.101 & & - & $* * *$ *. . 179 & متوسط \\
\hline $1 . \wedge \leqslant 7$ & - & $\cdots, \ldots \leqslant \wedge$ & *...रr।V & منخفض \\
\hline
\end{tabular}

ولمعرفة مصدر التباين للفروق بين المتوسطات الحسابية لمجموعات المبحوثين أجرى الاختبار البعدي L.S.D بطريقة أقل فرق معنوي، حيث ظهر أن مستوى الإثباعات المتحققة

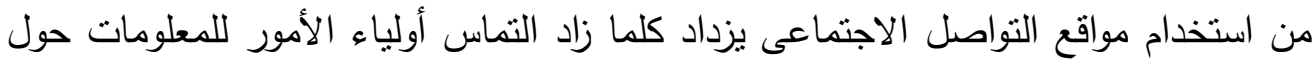

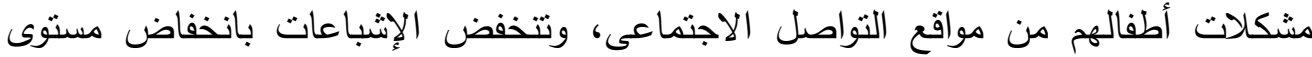

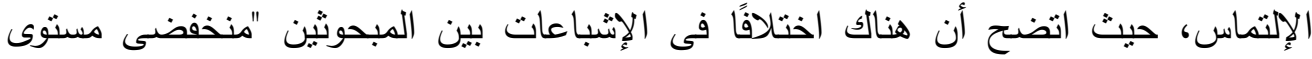
التماس المعلومات"، و "المبحوثين مرتفعى مستوى التماس المعلومات" بفرق بين المتوسطين

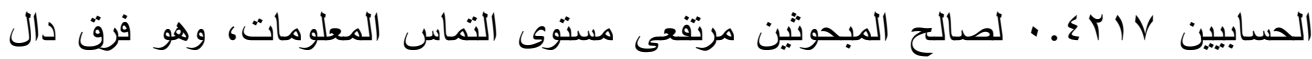

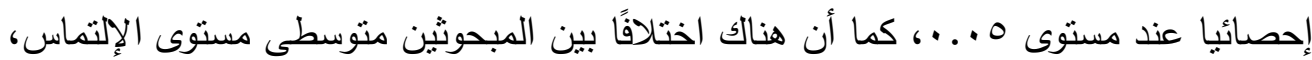

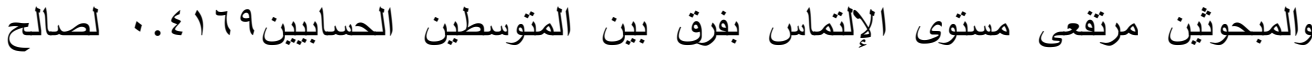

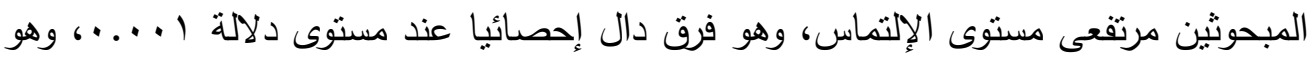

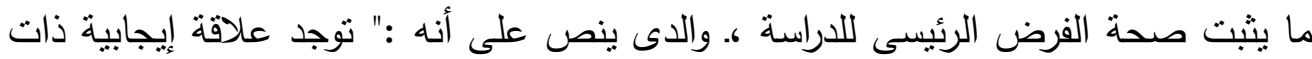

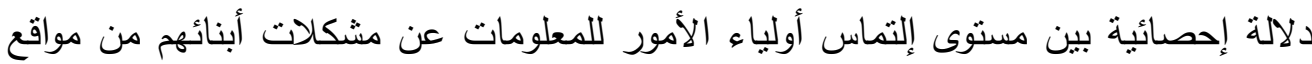
التواصل الاجتماعي، والاشباعات المتحققة لهم من هدا الإلتماس".

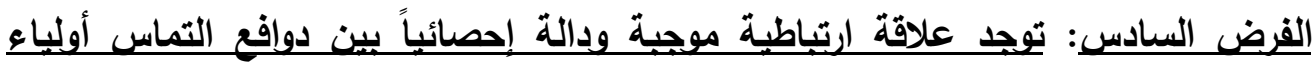
الأمور للمعلومات حول مشكلات أطقالهي من مواقع التواصل الاجتماعى والإشباعات

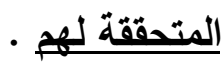
جدول رقم (Yo) معامل ارتباط بيرسون بين درجات المبحوثين على مقياس دوافع التماس المعلومات

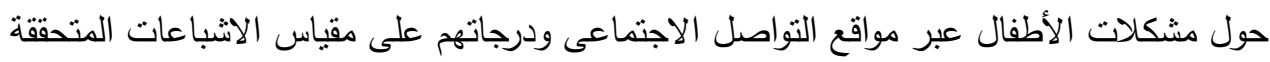

\begin{tabular}{|c|c|c|c|}
\hline \multicolumn{3}{|c|}{ دوافع التماس المعلومات حول مشكلات الأطفال } & \multirow[t]{2}{*}{ 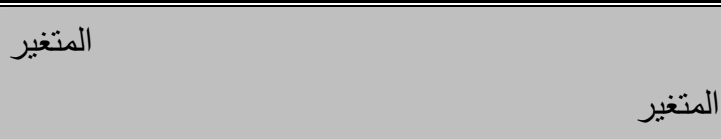 } \\
\hline 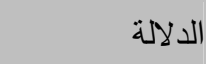 & قيمة بيرسون & 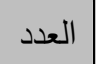 & \\
\hline & $* * * . . Y T V$ & $T Y \varepsilon$ & الاجتماعى الاشباعات المتحققة من استخدام مواقع التواصل \\
\hline
\end{tabular}

اتضح من الجدول السابق باستخدام معامل ارتباط بيرسون وجود علاقة ارتباطبه موجبة

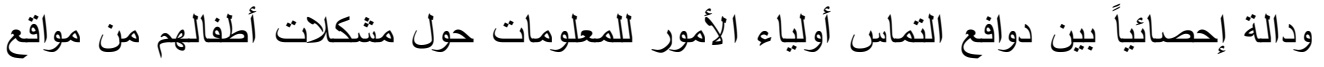


التواصل الاجتماعى ومستوى الإشباعات المتحققة لهم من استخدام هده المواقع ،حيث بلغت

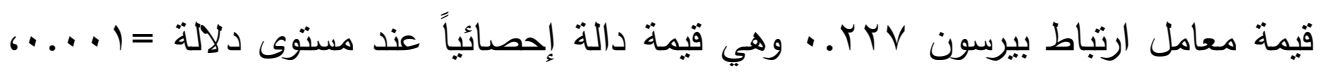
وبدلك فقد تحققت صحة هذا الفرض: "توجد علاقة ارتباطية موجبة ودالة إحصائياً بين دوافع التماس أولياء الأمور للمعلومات حول مشكلات اطفالهم من مواقع التواصل

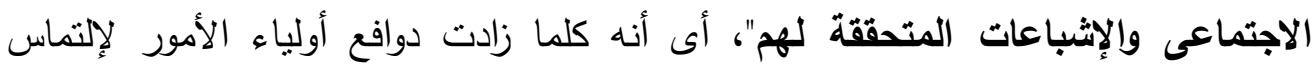

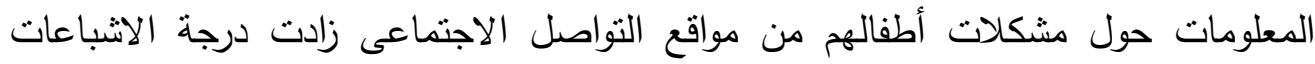
المتحققة لهم من استخدام هده المواقع كمصدر للمعلومات حول مشكلات أطفالهم.

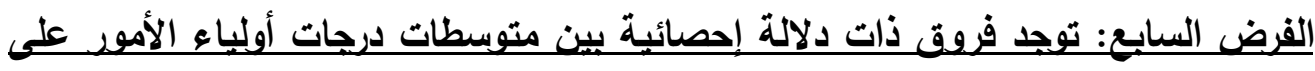
مقياس التماس المعلومات حول مشكلات أطفالهي من مواقع التواصل الإجتماعى تبعاً

\section{لاختلاف المتفيرات الديموحرافية لهــــ}

أ- توجد فروق ذات دلالة إحصائية بين متوسطات درجات أولياء الأمور على مقياس التماس

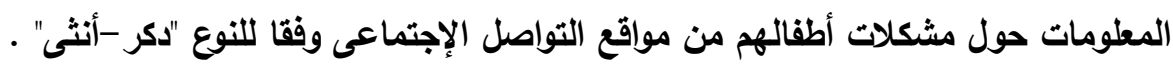
جدول (Y )

اختبار (ت) لدلالة الفروق بين المبحوثين في مستويات التماس المعلومات وفقا للنوع "دكور -إناث"

\begin{tabular}{|c|c|c|c|c|c|c|}
\hline الدلالة & درجة الحرية & قيمة ت & الانحراف المعياري & المتوسط & العدد & المجموعات \\
\hline \multirow{2}{*}{ دالة** } & \multirow{2}{*}{ rYr } & \multirow{2}{*}{ r.9Y4 } &..$\vee 7199$ & $1.7 V r$ & $10 \leqslant$ & 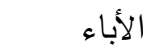 \\
\hline & & &..$T ा Y$. & T.9Y17 & iv. & الأمهات \\
\hline
\end{tabular}

تثبير نتائج اختبار "ت" فى الجدول السابق إلى وجود فروق ذات دلالة إحصائية بين متوسطات

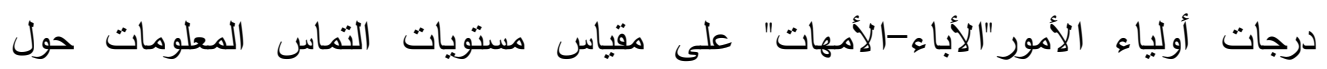

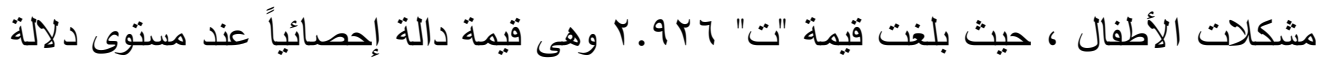
ا...، وبالتالى فقد تثبت صحة هذا الفرض: "توجد فروق ذات دلالة إحصائية بين متوسطات درجات أولياء الأمور على مقياس التماس المعلومات حول مشكلات الأطفال من فن فئل

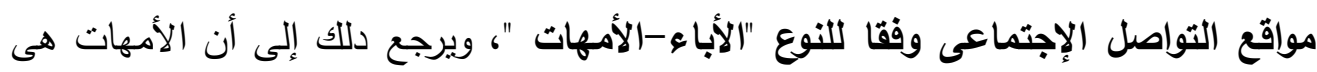

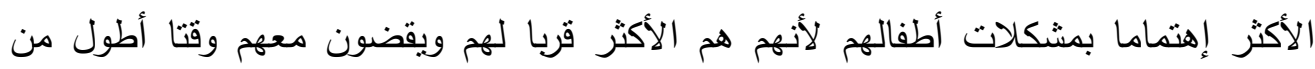

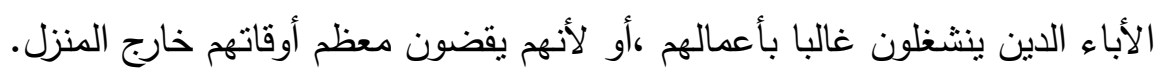

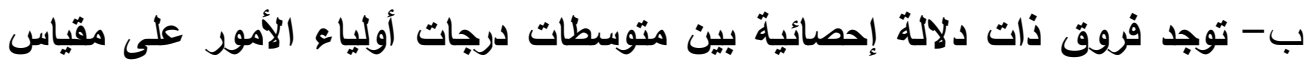
التماس المعلومات حول مشكلات أطفالهم من مواقع التواصل الإجتماعى تبعاً لاختلاف السن. 


\section{جدول رقم (rv)}

تحليل التباين أحادي الاتجاه بين متوسطات درجات المبحوثين على مقياس التماس المعلومات حول مشكلات الأطفال تبعاً لاختلاف السن

\begin{tabular}{|c|c|c|c|c|c|}
\hline الدلالة & قيمة ف & متوسط مجموع & الحرية & مجموعات & مصدر التباين \\
\hline \multirow{3}{*}{ دالة *** } & \multirow{3}{*}{$r . \wedge 90$} & $\cdot . \leqslant \wedge$ & r &. .979 & بين المجموعات \\
\hline & & $r .01 r$ & rrl & IT\&.Arr & داخل المجموعات \\
\hline & & & Trt & $199.1 . r$ & المجمـوع \\
\hline
\end{tabular}

تشير بيانات الجدول السابق إلي وجود فروق ذات دلالة إحصائية بين مجموعات المبحوثين الذين يمثلون المستويات العمرية المختلفة ، وذلك علي مقياس التماس المعلومات

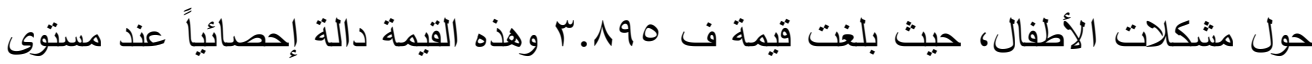
دلالة ا . . . . . وهوما يثبت صحة هذا الفرض والذى ينص على أنه: "توجد فروق ذات دلالة إحصائياً بين متوسطات درجات المبحوثين على مقياس التماس المعلومات حول مشكلات

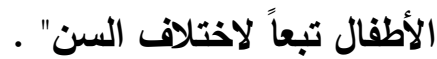

جدول ( ع r) نتائج تحليل L.S.D لمعرفة الفروق بين المجموعات علي مقياس التماس المعلومات حول مشكلات الأطفال.

\begin{tabular}{|c|c|c|c|c|}
\hline المتوسط & • ع سنة فأكثر & من •r - . ع سنه & أقل من • ب سنه & المجموعات \\
\hline T.MTI & & & - & أقل من · اسنه \\
\hline r.IT. & & - & ***..OYTE & من •r-. \\
\hline r...Ir & - & $\cdots \cdots \leqslant$ & **.. . \&Or & ع سنة فأكثر \\
\hline
\end{tabular}

ولمعرفة مصدر التباين للفروق بين المتوسطات الحسابية لمجموعات المبحوثين أجرى الاختبار البعدي L.S.D بطريقة أقل فرق معنوي،واتضح أن مستوى التماس المعلومات حول مشكلات الأبناء من مواقع التواصل الاجتماعى يزداد كلما انخفض المستوى العمرى للآباء

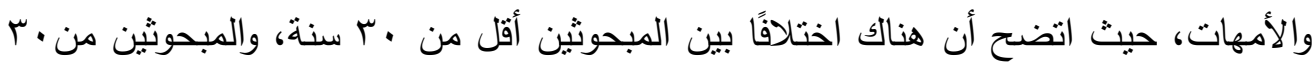

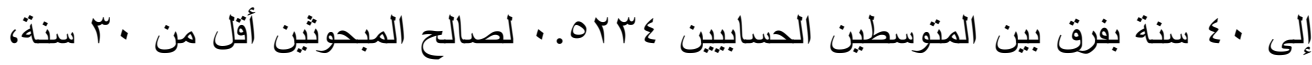
وهو فرق دال إحصائيا عند مستوى دلالة ا ...... كما أن هناك اختلافًا بين المبحوثين أقل بـن

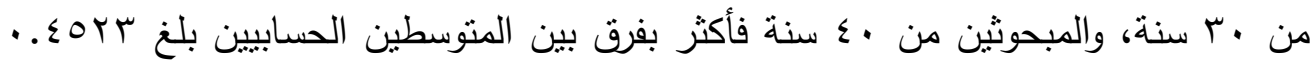

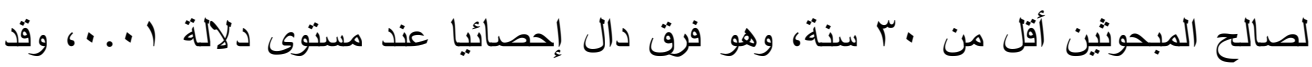

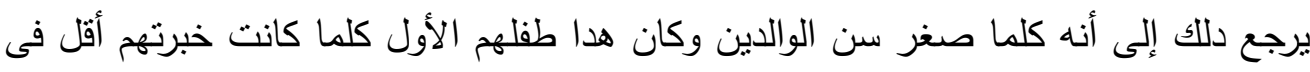
التعامل مع مشكلاته مما يجعلهم يلجأون بصوره أكبر لمواقع التواصل الإجنماعى وغيرها من 
المصادر التى تساعدهم على حل مشكلاته، ودلك بمعدل أكبر من غيرهم من أولياء الأمور

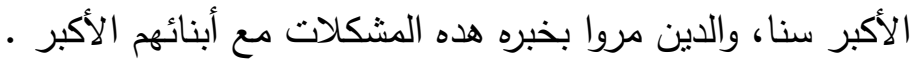

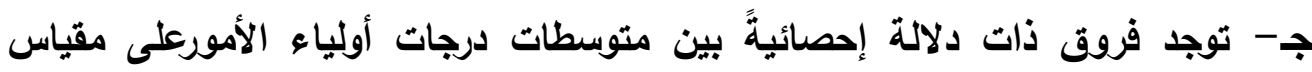

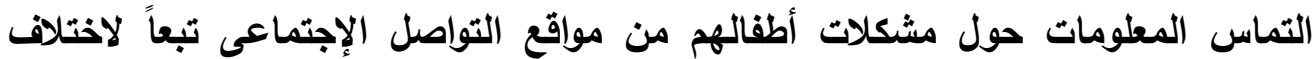

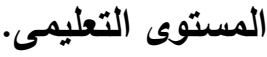
جدول رقم (Y^) تحليل التباين أحادي الاتجاه بين منوسطات درجات المبحوثين على مقياس

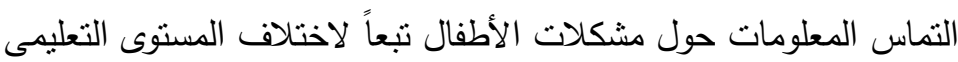

\begin{tabular}{|c|c|c|c|c|c|}
\hline الدلالة & قيمة ف & متوسط مجموع المربعات & درجة الحرية & مجموعات المربعات & مصدر التباين \\
\hline \multirow{3}{*}{ دالة**** } & \multirow{3}{*}{$\varepsilon . r 9 \wedge$} & $1 . .11$ & r & r.171 & بين المجموعات \\
\hline & & E.MY & rr & $11 \leq .9 .1$ & داخل المجموعات \\
\hline & & & אזr & $M T .1 Y T$ & المجموع \\
\hline
\end{tabular}

تتشير بيانات الجدول السابق إلي وجود فروق ذات دلالة إحصائية بين مجموعات

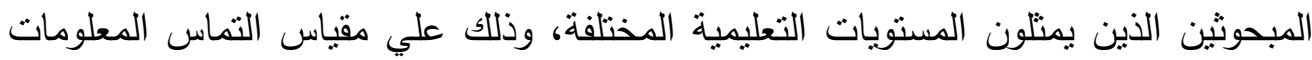

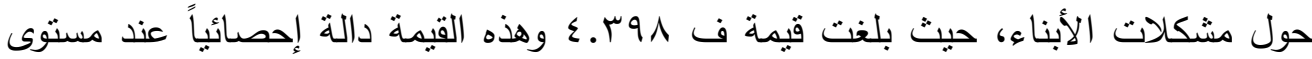
دلالة ا ....، وهو ما يثبت صحة هذا الفرض: "توجد فروق ذات ذهات دلالة إحصائياً بين متوسطات درجات أولياء الأمور على مقياس التماس المعلومات حول مشكلات أطفالهم تبعاً لاختلاف المستوى التعليمى لهم". جدول (乏) نتائج تحليل L.S.D لمعرفة الفروق بين المجموعات علي مقياس التماس المعلومات حول

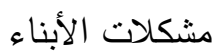

\begin{tabular}{|c|c|c|c|c|}
\hline المتوسط & أعلى من جامعى & جامعى & أقل من جامعى & المجموعات \\
\hline r.sor & & & - & أقل من جامعى \\
\hline T.MIT & & - & ***. . Tor & جامعى \\
\hline r.UT & - &. $.10 r$ & ****orr . & أعلى من جامعى \\
\hline
\end{tabular}

ولمعرفة مصدر التباين للفروق بين المتوسطات الحسابية لمجموعات المبحوثين أجرى الاختبار البعدي L.S.D بطريقة أقل فرق معنوي، حيث ظهر أن مستوى التماس المعلومات

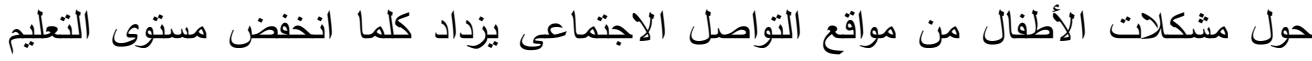

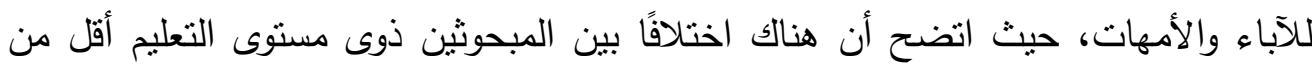
جامعى، والمبحوثين ذوى مستوى التعليم الجامعى بفرق بين المتوسطين الحسابيين بلغ لغنين 


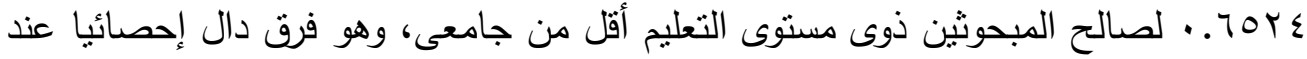

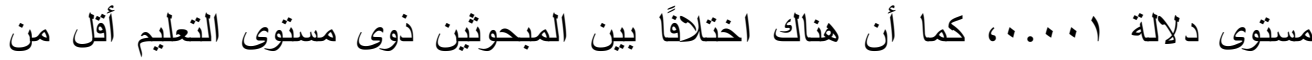

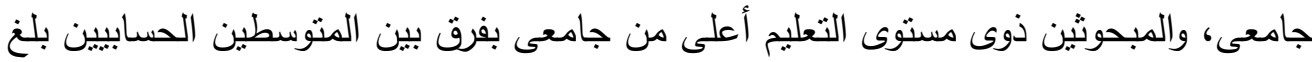

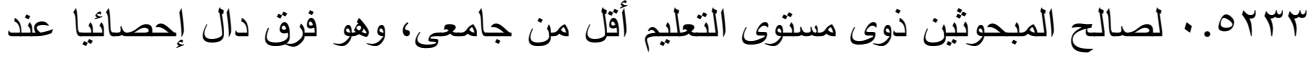

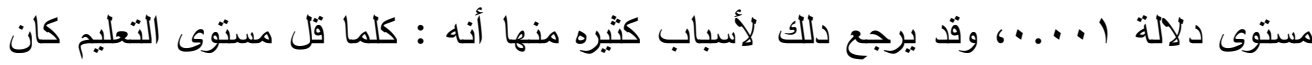

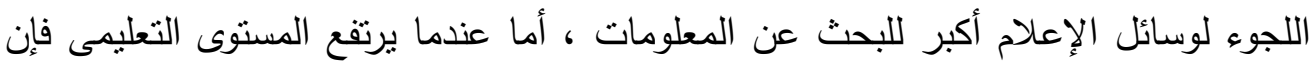

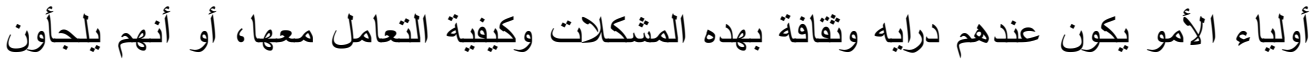

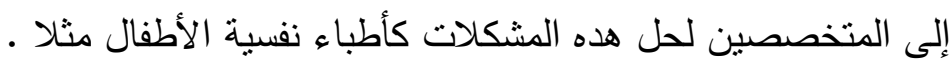
د - توجد فروق ذات دلالة إحصائية بين متوسطات درجات أولياء الأمور على مقياس

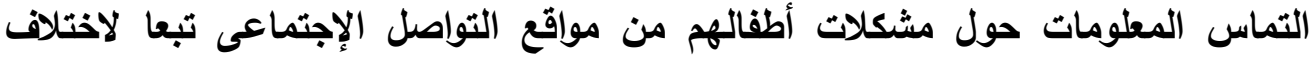

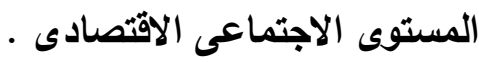

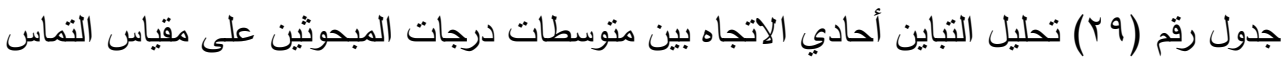

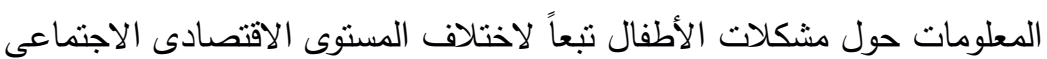

\begin{tabular}{|c|c|c|c|c|c|}
\hline 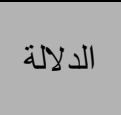 & قيمة ف & منوسط مجموع المربعات & الحربة & المربعات & مصدر التباين \\
\hline \multirow{3}{*}{ دالة*** } & \multirow{3}{*}{$0.70 Y$} & מת . & r & $1 . \leqslant 7 V$ & بين المجموعات \\
\hline & & $0 . \Gamma \wedge 9$ & Mr & וזr...r| & داخل المجموعات \\
\hline & & & Trt & IY.1NK & المجموع \\
\hline
\end{tabular}

تشير بيانات الجدول السابق إلي وجود فروق ذات دلالة إحصائية بين مجموعات

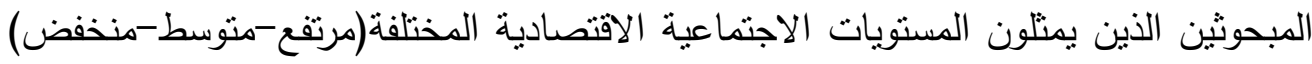

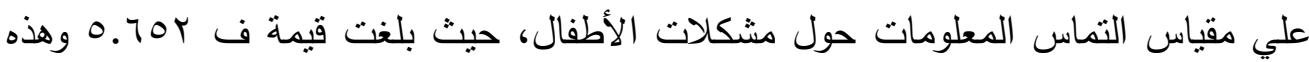

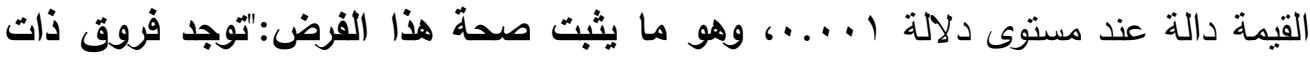

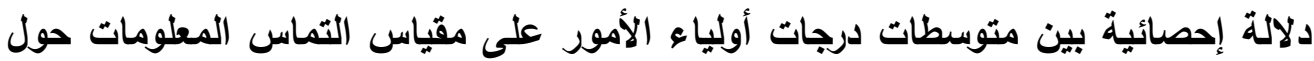

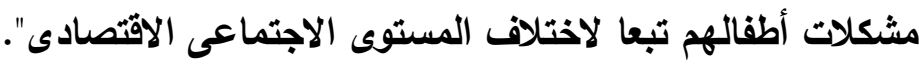

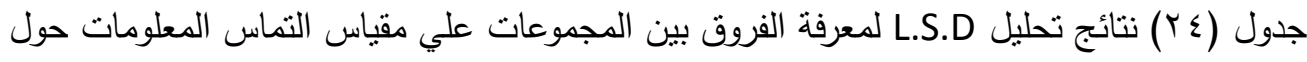

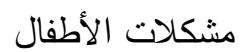

\begin{tabular}{|c|c|c|c|c|}
\hline المتوسط & مرتفع & منوسط & منخفض & المجموعات \\
\hline r.rqA & & & - & منخفض \\
\hline$r . . r_{1}$ & & - & $* * * . . \leqslant 9 \wedge 0$ & متوسط \\
\hline $1.9 \vee 9$ & - & ...rTr & $* * * .01 Y$ & مرتقع \\
\hline
\end{tabular}


ولمعرفة مصدر التباين للفروق بين المتوسطات الحسابية لمجموعات المبحوثين أجرى الاختبار البعدي L.S.D بطريقة أقل فرق معنوي، حيث ظهر أن مستوى التماس المعلومات

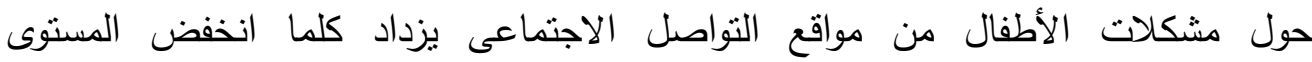

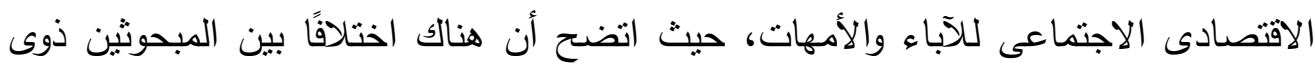

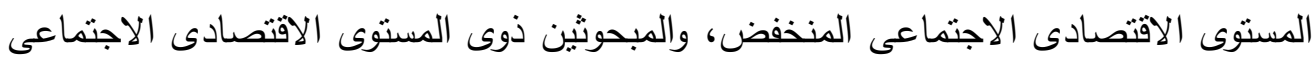

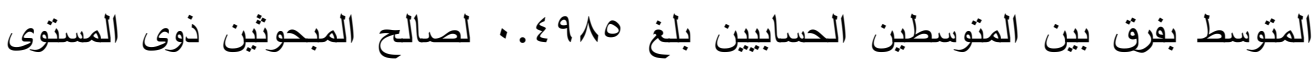

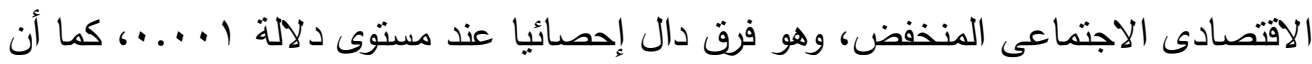
هناك اختلافًا بين المبحوثين ذوى المستوى الاقتصادى الاجتماعى المنخفض، والمبحوثين ذوى درى

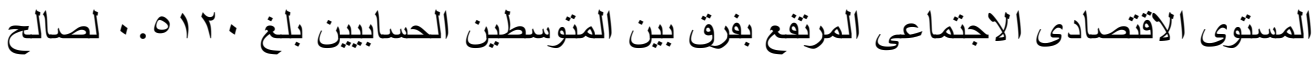

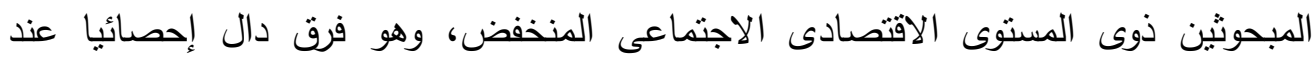

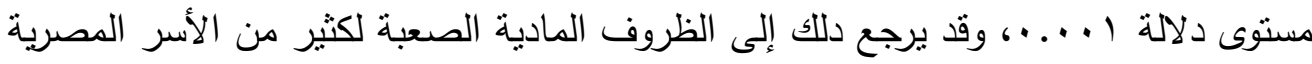

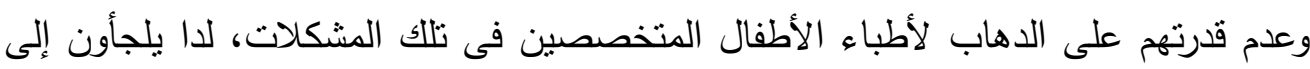
وسائل الإعلام بصقه خاصة مواقع التواصل الإجتماعى لإلتماس المعلومات منها حول

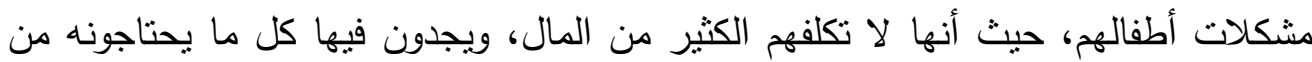
معلومات، وصفحات للمتخصصين فى مجال الطفولة ومشكلاتها ويردون على أسألتهز

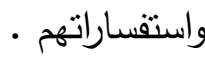
الفرض الثامن: توجد فروق ذات دلالة إحصائية بين متوسطات درجات أولياء الأمور على مقياس الاشباعات المتحققة من التماس المطلومات حول مشكلات أطفالهم من مواقع

\section{التواصل الاجتماعى تبعاً لاختلاف المتفيرات الديموجرافية.}

أ- توجد فروق ذات دلالة إحصائية بين متوسطات درجات أولياء الأمور على مقياس

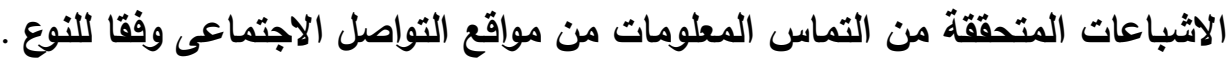

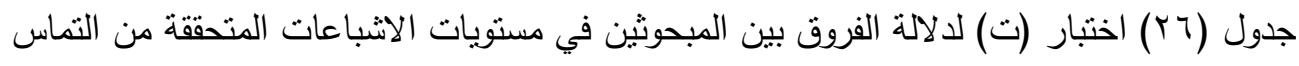

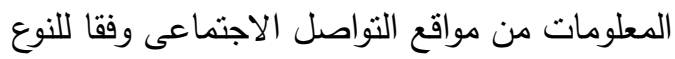

\begin{tabular}{|c|c|c|c|c|c|c|}
\hline 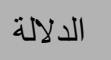 & درجة الحربة & قيمة ت & الانحراف المعياري & المتوسط & العدد & المجموعات \\
\hline \multirow{2}{*}{ دالة*** } & \multirow{2}{*}{ rrr } & \multirow{2}{*}{$r .17 r$} & .1170 & 1.071 & $10 \leqslant$ & الأباء \\
\hline & & & $\because V / r$ & r.VON & IV. & الأمهات \\
\hline
\end{tabular}


تدل نتائج اختبار "ت" فى الجدول السابق على وجود فروق ذات دلالة إحصائية بين

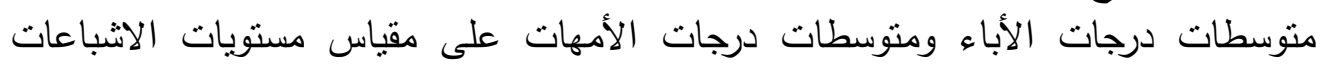

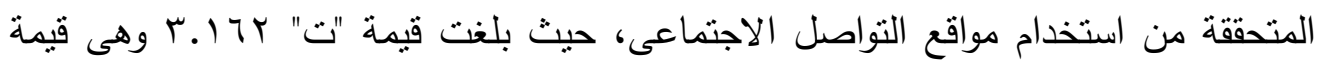

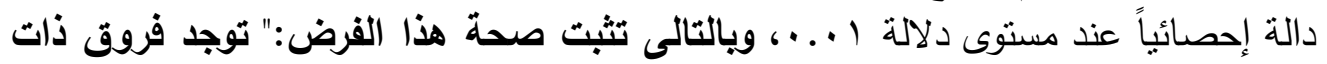

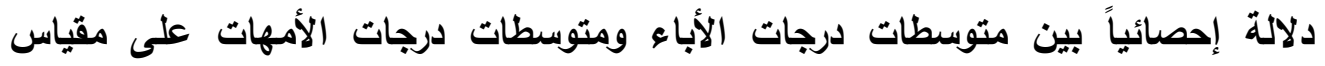

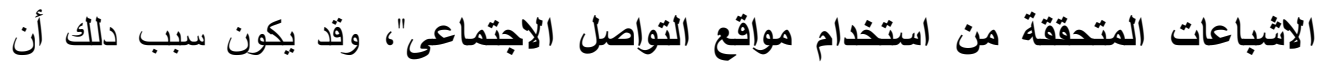

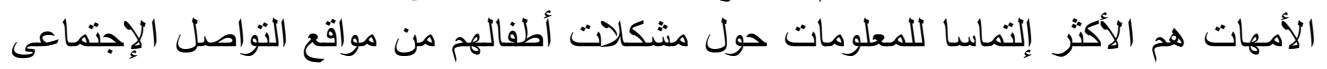

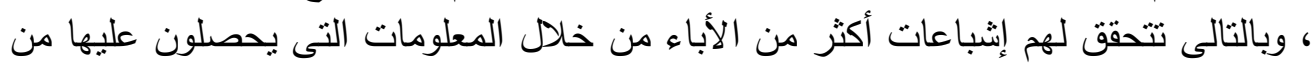

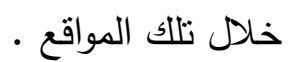

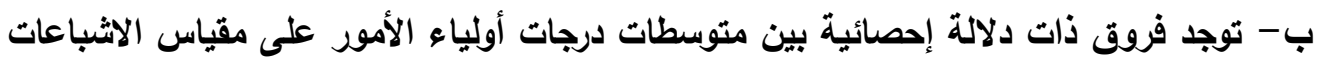

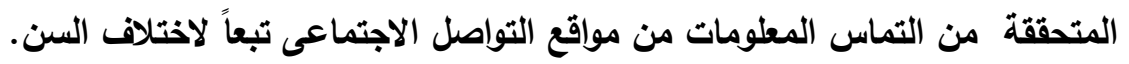

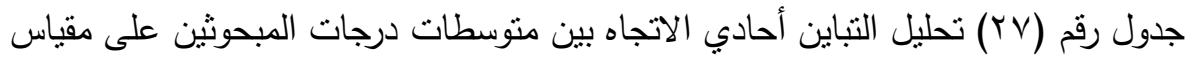

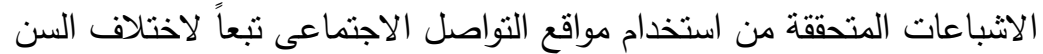

\begin{tabular}{|c|c|c|c|c|c|}
\hline الدلالة & قيمة ف & متوسط مجموع المربعات & الحربة & مجموعات & مصدر التباين \\
\hline \multirow{3}{*}{ دالة*** } & \multirow{3}{*}{ ד. } & T.MIT & r & א.T & بين المجموعات \\
\hline & &.$r \wedge \varepsilon$ & MrI & qאוזים & داخل المجموعات \\
\hline & & & Trt & $1 \leq . . A V Y$ & المجمـوع \\
\hline
\end{tabular}

تدل بيانات الجدول السابق على وجود فروق ذات دلالة إحصائية بين مجموعات

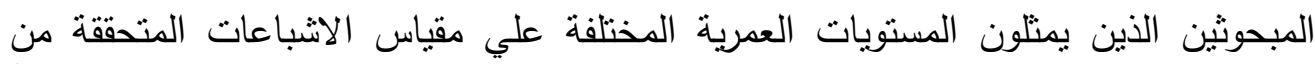

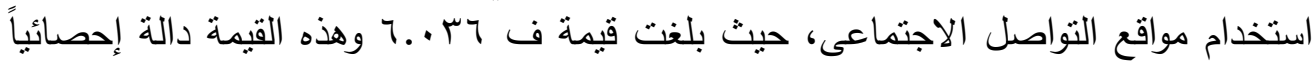

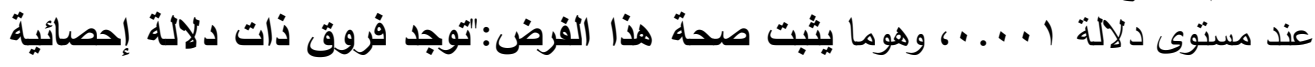

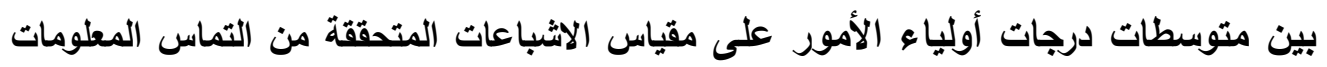
من مواقع التواصل الاجتماعى تبعاً لاختلاف الست السن.

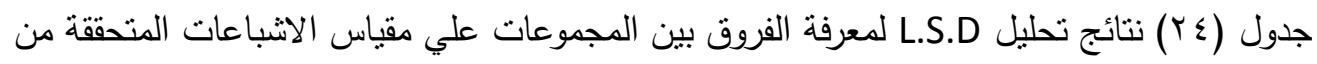

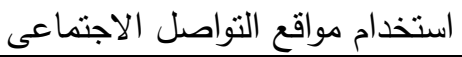

\begin{tabular}{|c|c|c|c|c|}
\hline المتوسط & • ع سنه فأكثر & من •r -. ع سنه & أقل من • r سنه & المجموعات \\
\hline r.77. & & & - & أقل من • س سنه \\
\hline r.0Tr & & - & $* . r I T V$ & من · r- ع عسنه \\
\hline$r . r \leq q$ & - &. $.9 \wedge r$ & 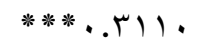 & •ـ سنة فأكثر \\
\hline
\end{tabular}

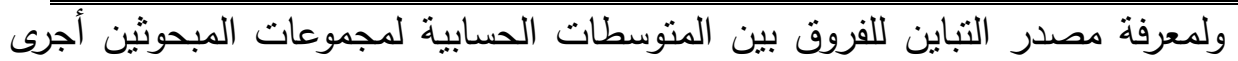

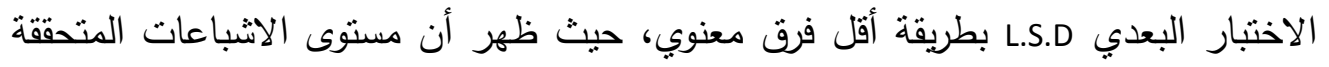

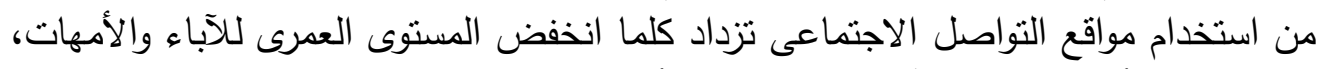

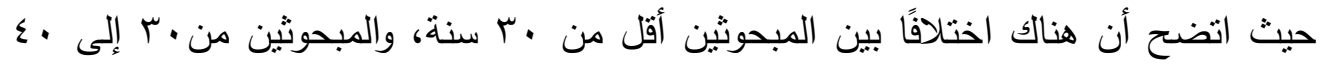




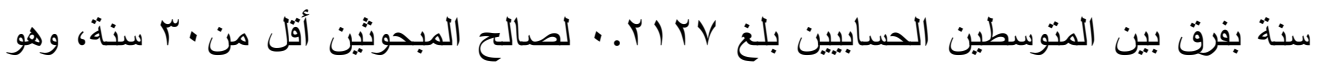

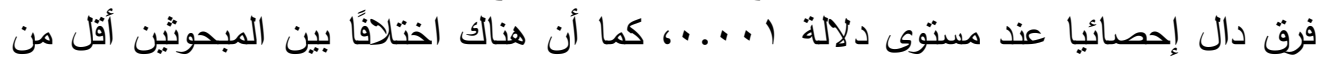

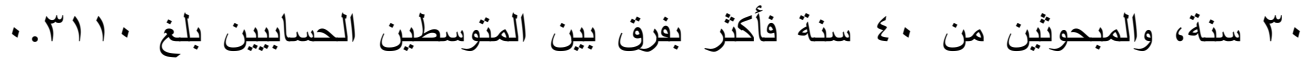

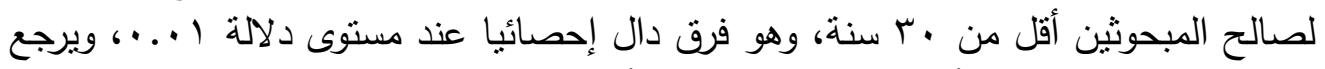

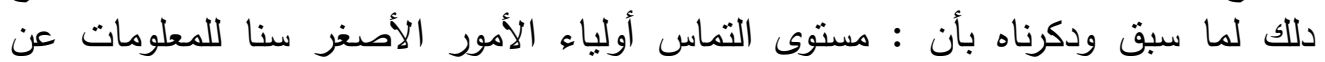

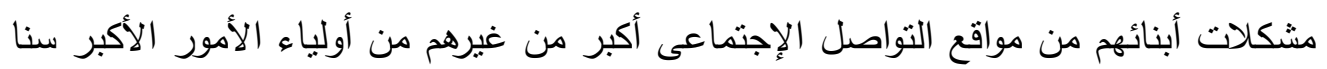

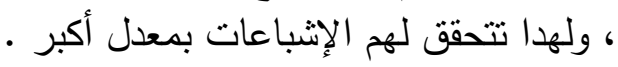

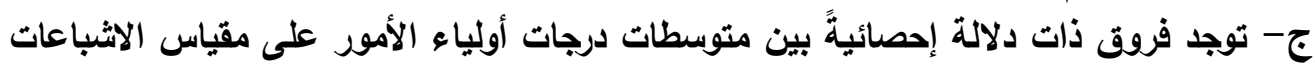

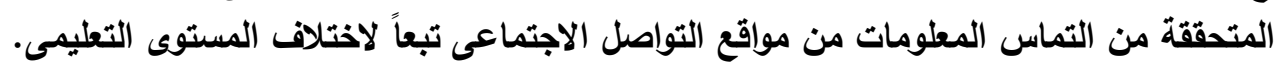

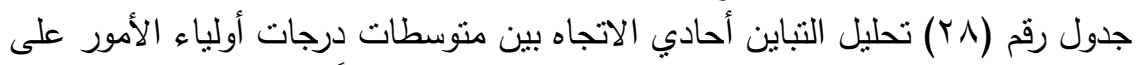

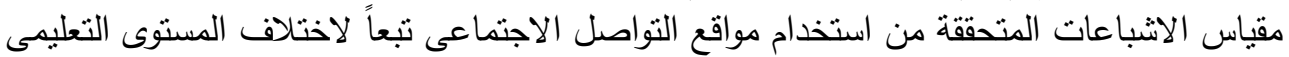

\begin{tabular}{|c|c|c|c|c|c|}
\hline الدلالة الد & قبمة ف & متوسط مجموع المربعات & الحربة & مجموعات المربعات & مصدر التباين \\
\hline \multirow{3}{*}{ دالة*** } & \multirow{3}{*}{0.71.} & $Y .0 \leqslant V$ & r & $0.9 \varepsilon$ & بين المجموعات \\
\hline & & $. . \leqslant 0 \leqslant$ & I & س7 & داخل المجموعات \\
\hline & & & אזr & $177 . \mathrm{rov}$ & المجموع \\
\hline
\end{tabular}

تدل بيانات الجدول السابق على وجود فروق ذات دلالة إحصائية بين مجموعات

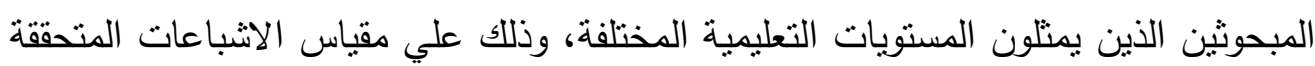

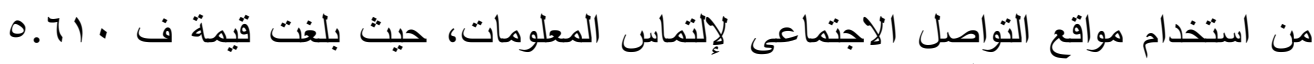

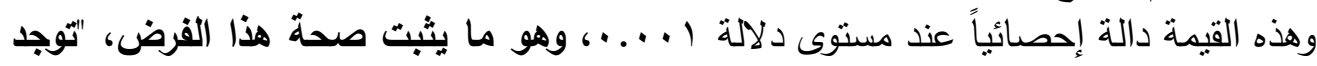

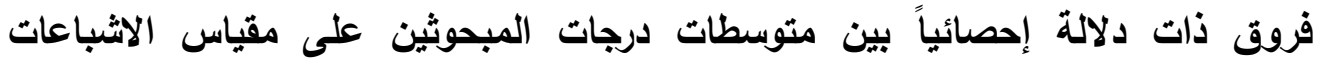

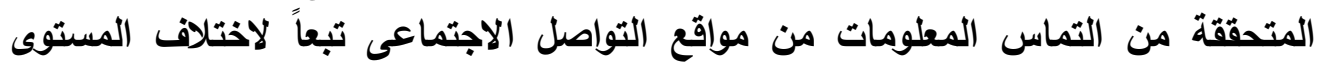

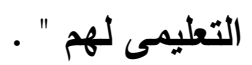
جدول (عاب) نتائج تحليل L.S.D لمعرفة الفروق بين المجموعات علي مقياس الاشباعات المتحققة من

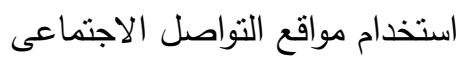

\begin{tabular}{|c|c|c|c|c|}
\hline المتوسط & أعلى من جامعى & جامعى & أقل من جامعى & المجموعات \\
\hline r.ד. & & & - & أقل من جامعى \\
\hline r.rII & & - & ****. . Y & جامعى \\
\hline$r . .91$ & - & $\ldots \varepsilon \leqslant V$ & $* * . . r r \leq q$ & أعلى من جامعى \\
\hline
\end{tabular}

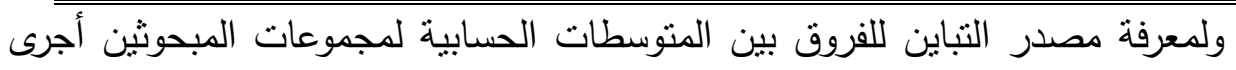
الاختبار البعدي L.S.D بطريقة أقل فرق معنوي، حيث ظهر أن أن مستوى الاشباعات المتحققة

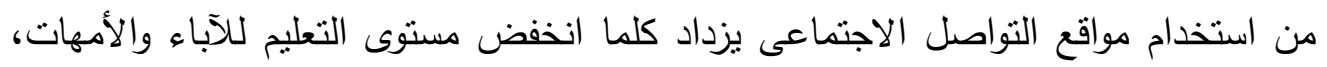

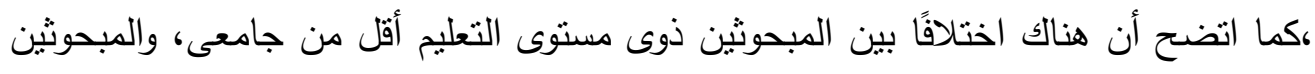




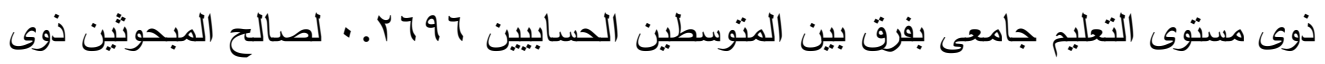

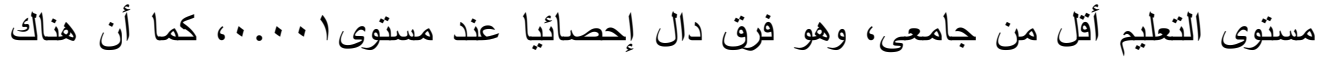

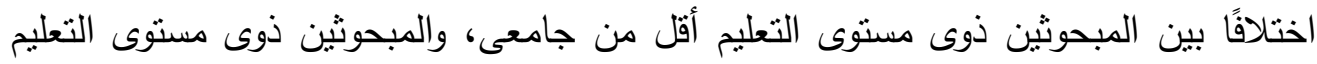

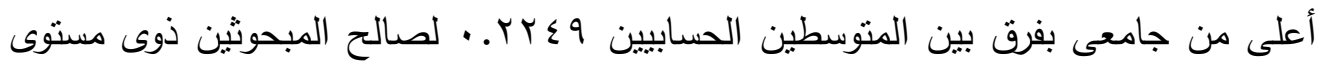

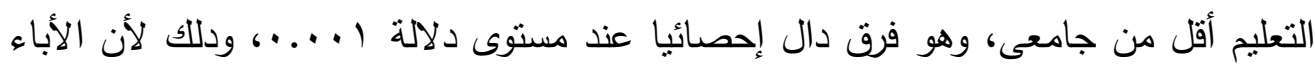

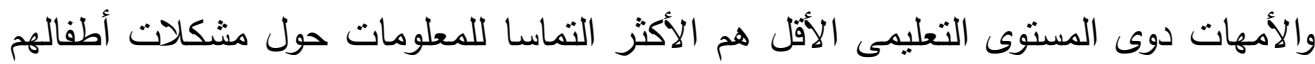

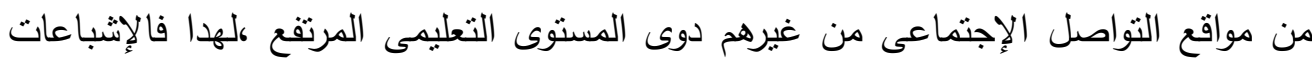

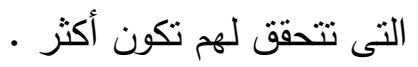
د-توجد فروق ذات دلالة إحصائية بين منوسطات درجات أولياء الأمور على مقياس

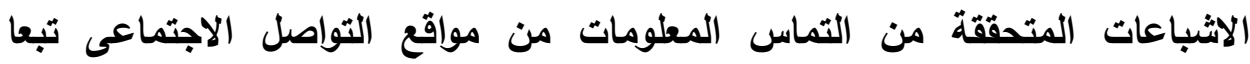
لاختلاف المستوى الاجتماعى الاقتصادى.

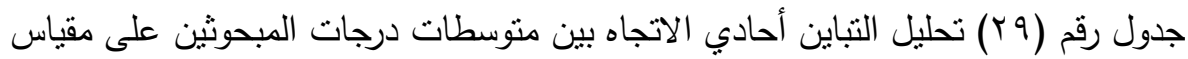

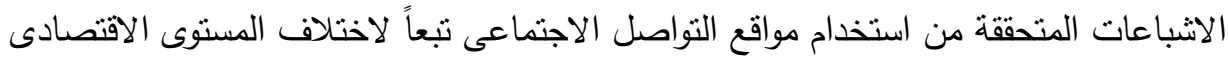

\begin{tabular}{|c|c|c|c|c|c|}
\hline الدلالة الة & قيمة ف & منوسط مجموع & درجة الحربة & مجموعات & مصدر التباين \\
\hline \multirow{3}{*}{ دالة *** } & \multirow{3}{*}{$\begin{array}{r}11.9 . \\
r\end{array}$} & 0.10 & r & $1 \cdot \ldots$ & بين المجموعات \\
\hline & &.$\Sigma Y_{1}$ & ו וr & $1 \leqslant 9.0 \wedge r$ & داخل المجموعات \\
\hline & & & سץץ & $109.71 \%$ & المجموع \\
\hline
\end{tabular}

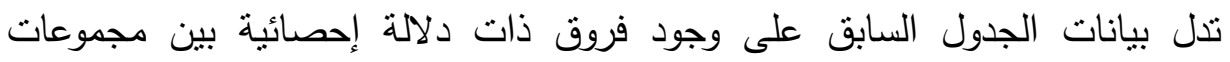

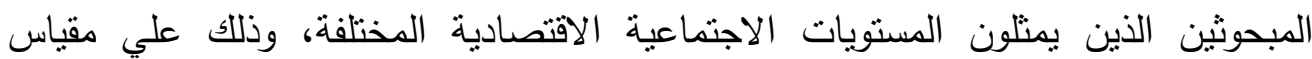

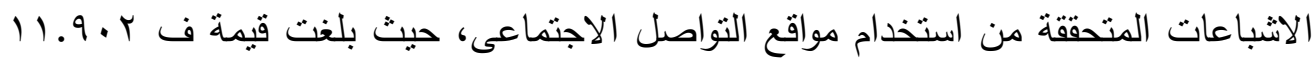

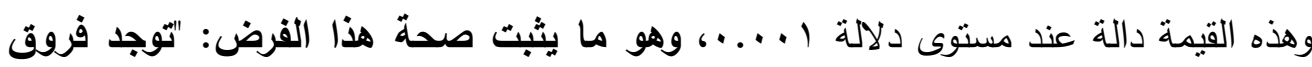

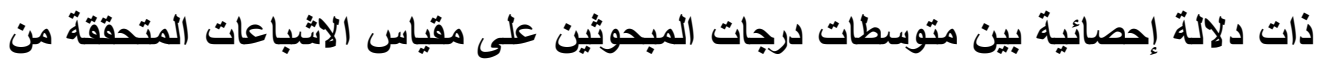

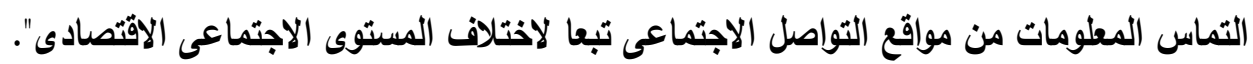

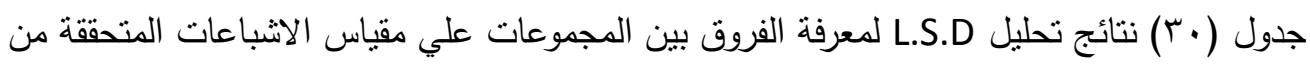

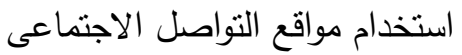

\begin{tabular}{|c|c|c|c|c|}
\hline المتوسط & مرتفع & متوسط & منذفض & المجموعات \\
\hline T.VYE & & & - & منخفض \\
\hline r. $\varepsilon \cdot V$ & & - & ***..TITV & منوسط \\
\hline T.YOE & - & $.10 Y \varepsilon$ & $* * * . . \leq 799$ & مرتفع \\
\hline
\end{tabular}


ولمعرفة مصدر التباين للفروق بين المتوسطات الحسابية لمجموعات المبحوثين أجرى الاختبار البعدي L.S.D بطريقة أقل فرق معنوي، حيث ظهر أن مستوى الاشباعات المتحققة

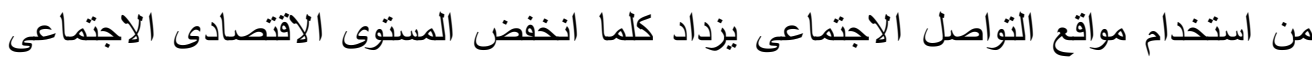

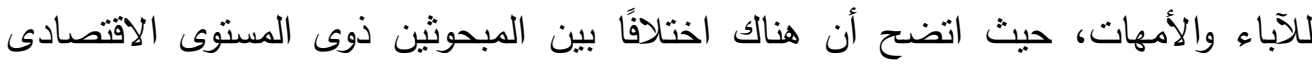

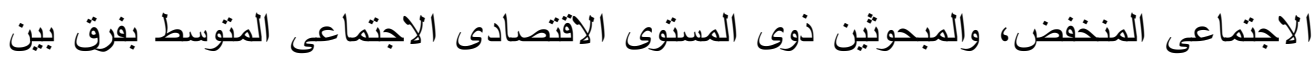

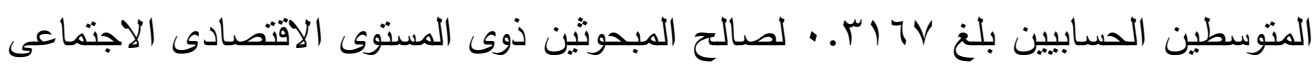

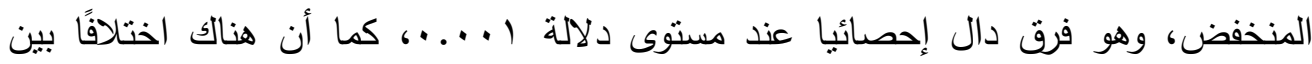

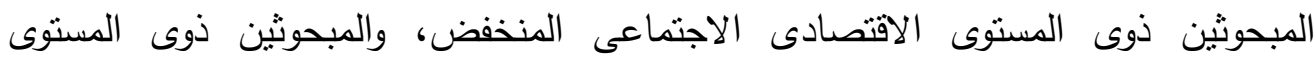

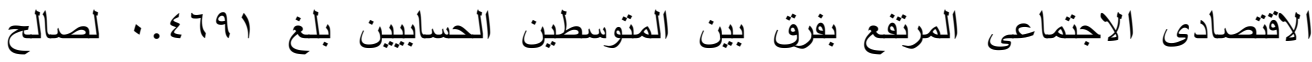

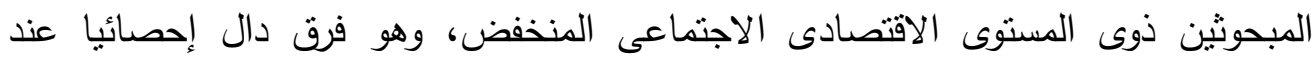

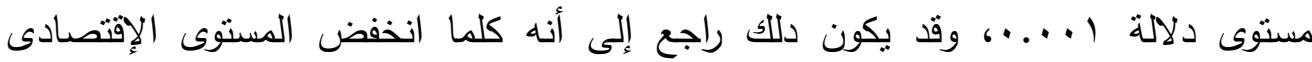
الإجتماعى لأولياء الأمور كلما زاد التماسهم للمعلومات عن مشكلات أطفالهم من وسائل الهاتل

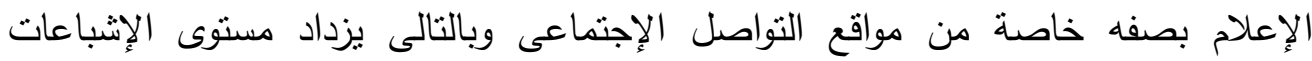

المتحقق لهم .

\section{ملخص نتائج الدراسية :}

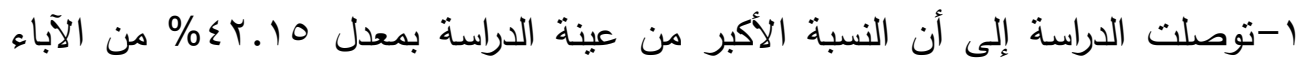

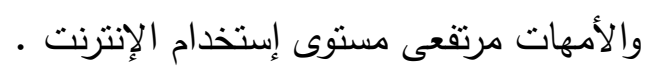

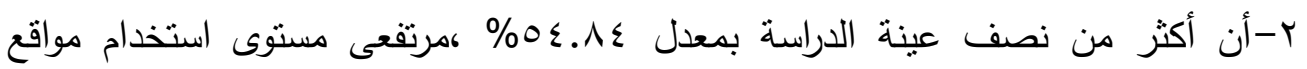

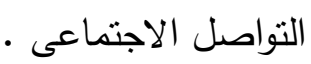

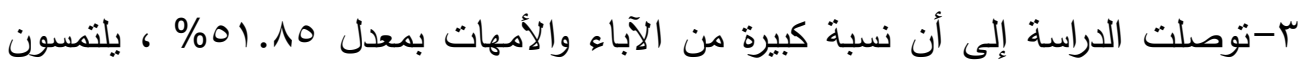

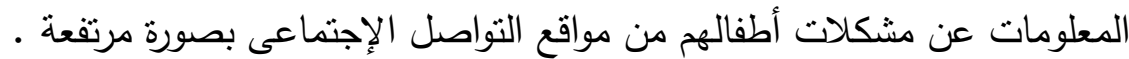
ع-نوصلت الدراسة إلى أن أهم مشكلات الأطفال التى يلتمس أولياء الأمور المعلومات التهات عنها

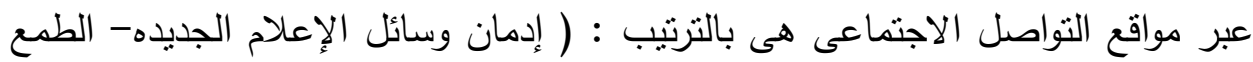

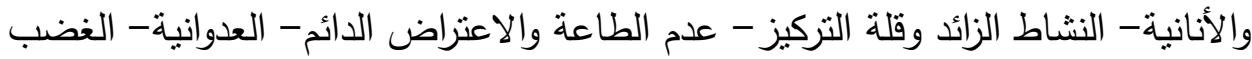

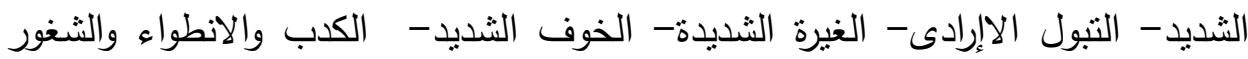

$$
\text { بالنقص - السرقة). }
$$

ه-أن أهم دوافع التماس أولياء الأمور للمعلومات حول مشكلات أطفالهم من مواقع التواصل

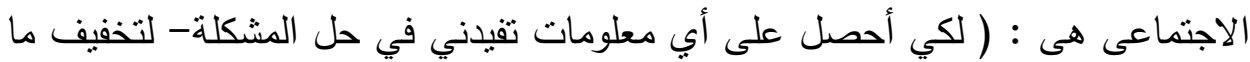

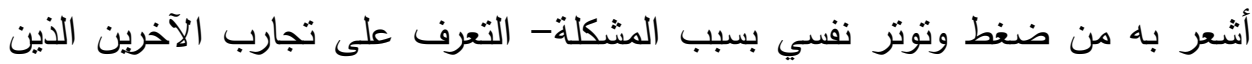


مروا بنفس المشكلة- التعرف على آراء الأطباء والمتخصصين في المشكلة - لكي أجد

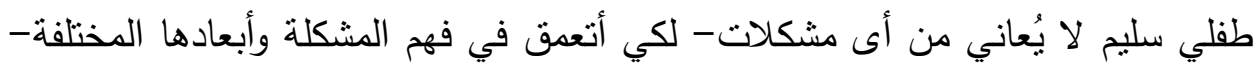

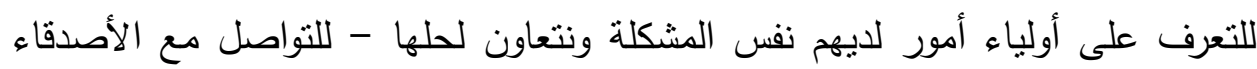

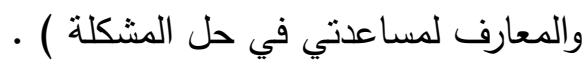

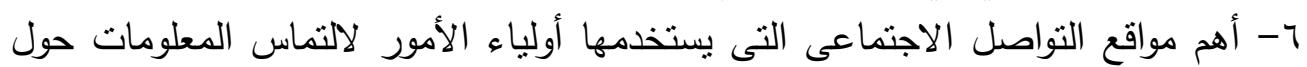

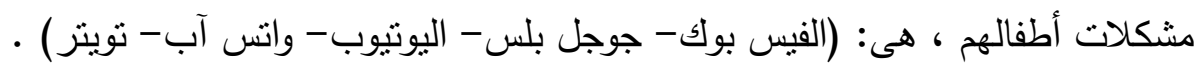

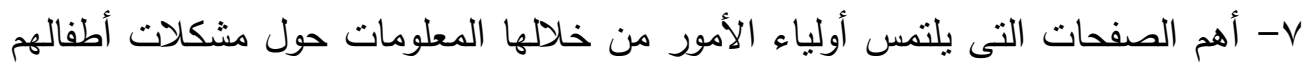

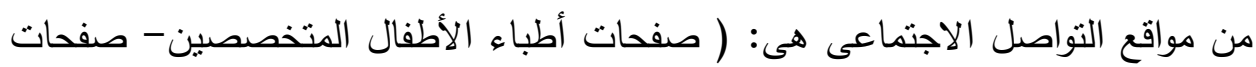

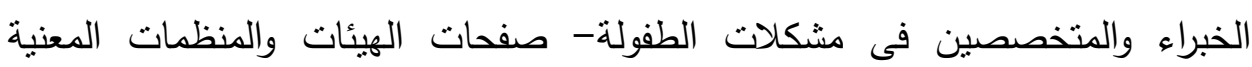
بالطفولة- صفحات أصدقاء لديهم وعي ومعرفة بمشكلات الطفولة- صفحات أولياء أمور

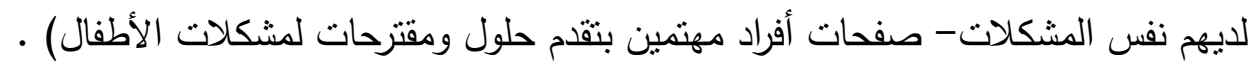

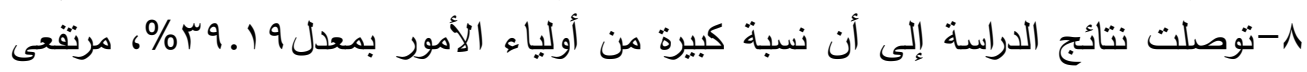

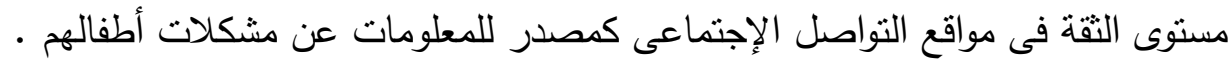

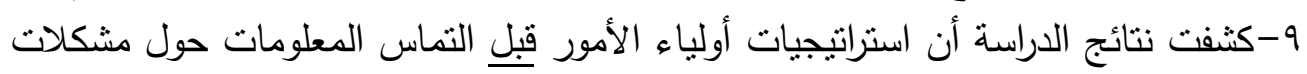

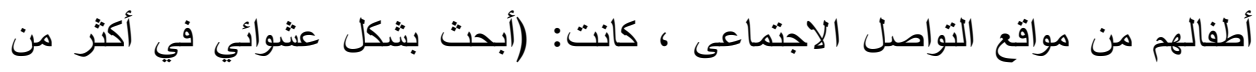
موقع - أحدد موقع بعينه أجد فيه المعلومات التي أبحث عنها - أبحث بشكل مباشر ودئ واتشيق في الموقع عما أريده من معلومات- أقوم ببحث سريع داخل الموقع فئه عن المشكلة- أطرح

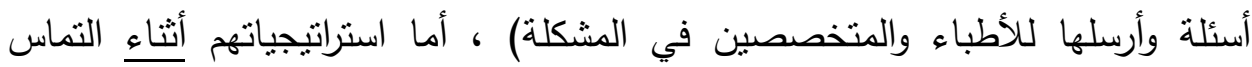

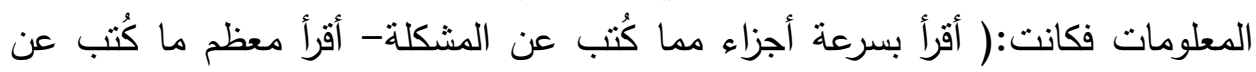

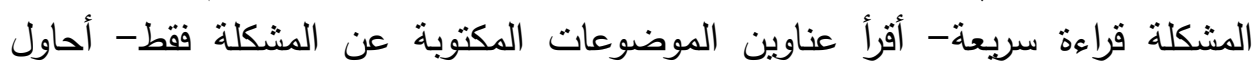

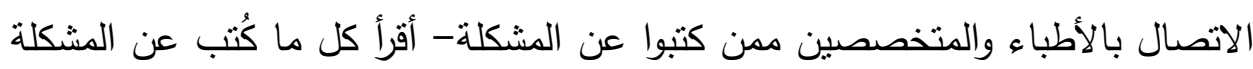
كاملاً قدر استطاعتي- أهتم بالصور والفيديوهات المصاحبة للموضوعات المكتوبة- أقرأ

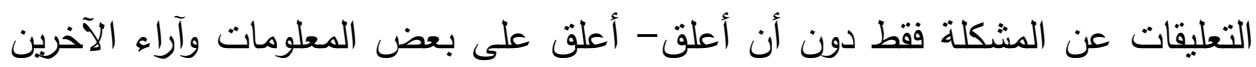

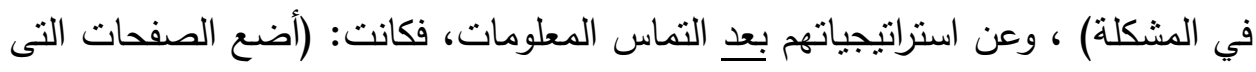

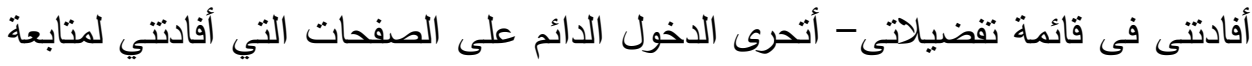

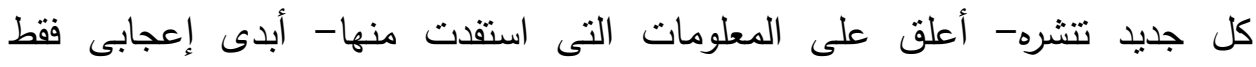

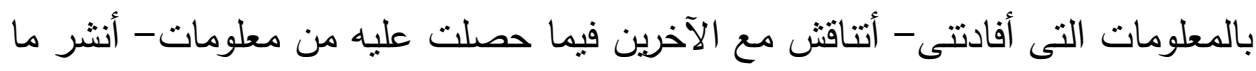

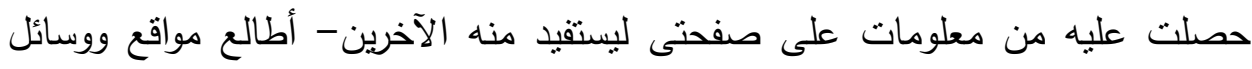

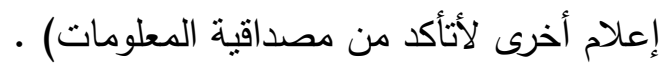

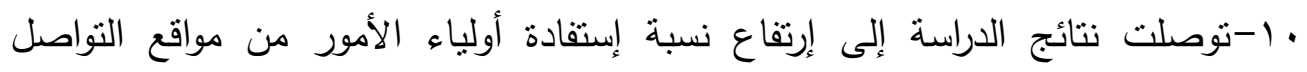

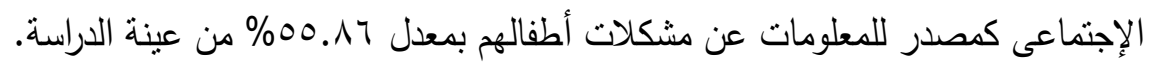




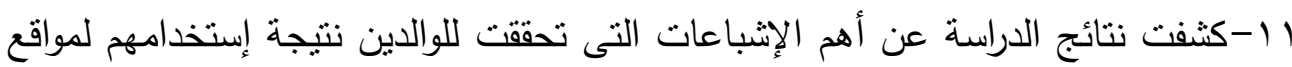

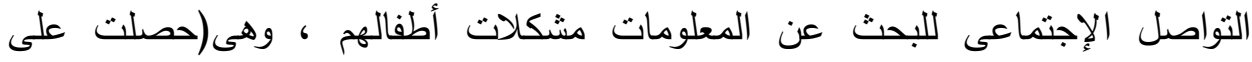
معلومات أفادتتي في حل المشكلة- تخلصت من الإحساس بالضيق والألم بسبب معاناة

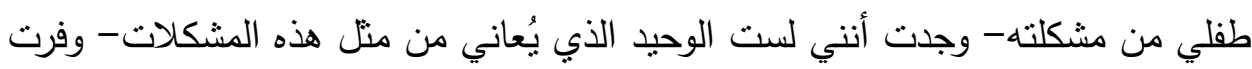

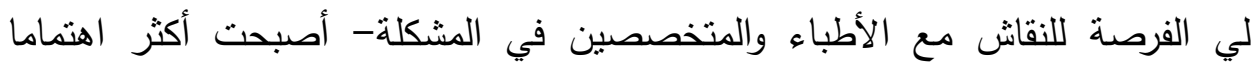

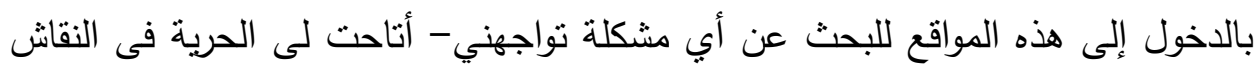

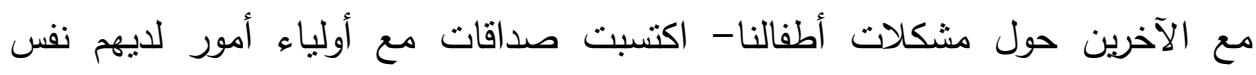

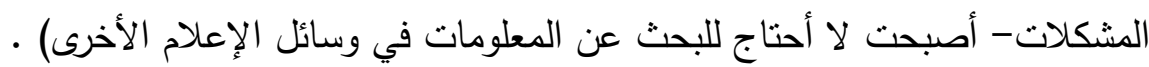

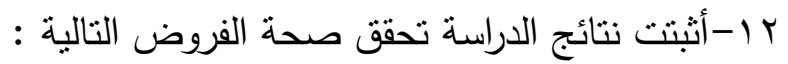
الفرض الأول: نوجد علاقة ارتباطية موجبة ودالة إحصائياً بين مستوى استخدام أولياء الأمور

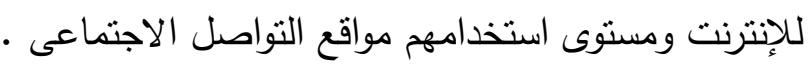
الفرض الثاني: نوجد علاقة ارتباطية موجبة ودالة إحصائياً بين مستوى استخدام أولياء الأمور

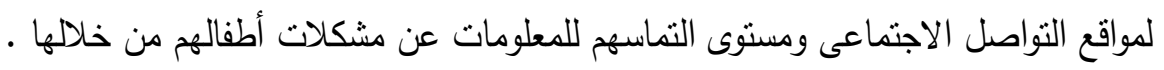

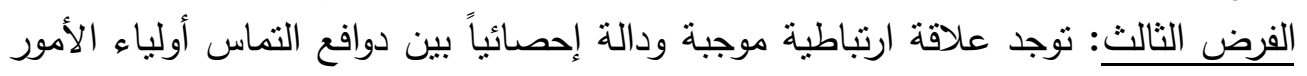

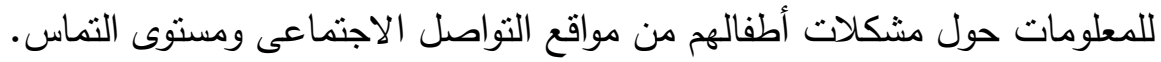

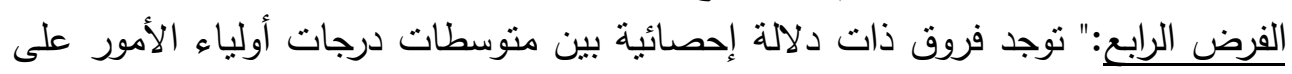

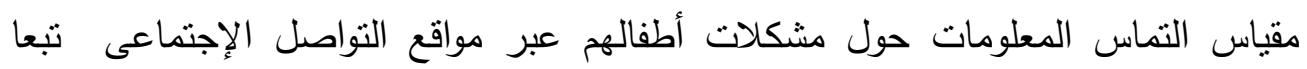
لاختلاف مستويات ثقتهم فى هده المواقع كمصدر للمعلومات. الفرض الخامس: توجد فروق ذات دلالة إحصائية بين متوسطات درجات أولياء الأمور على الماتى

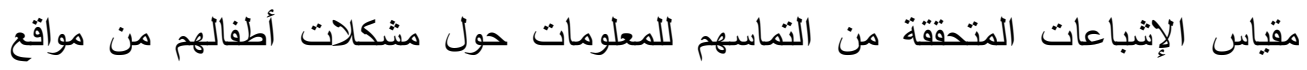

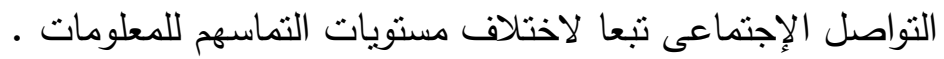
الفرض السادس: توجد علاقة ارتباطية موجبة ودالة إحصائياً بين دوافع التماس أولياء الأبعاء الأمور

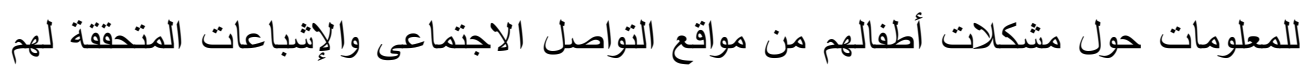

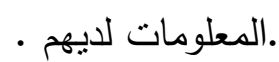

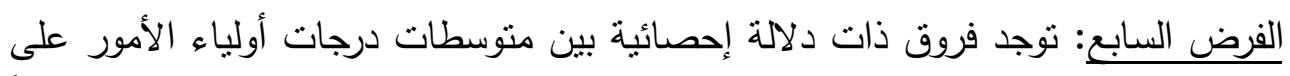

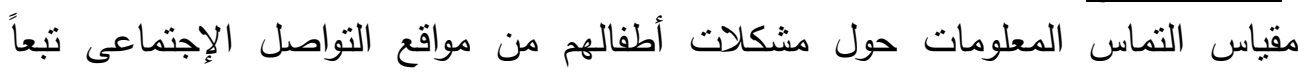

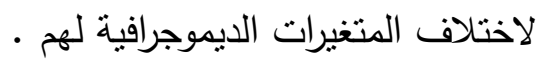

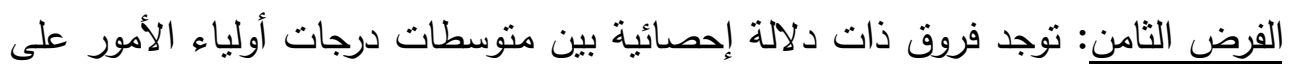

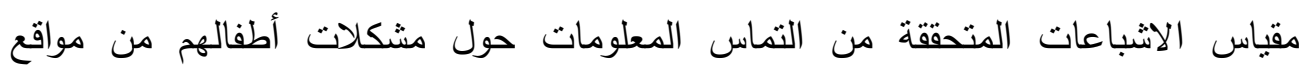
التواصل الاجتماعى تبعاً لاختلاف المتغيرات الديموجرافية. 


\section{توصيات الدراسة :}

لعلاج مشكلات الأطفال، أوالمساهمة فى حلها توصى الدراسة الوالدين والمربين باتباع

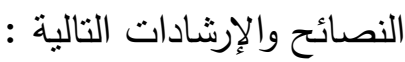

1- مشكلة الخوف: في حالة الخوف العارض أوالوقتي منل استيقاظ الطفل على الكوابيس أثناء الليل، فعلى الوالدين أن يهدؤا الطفل ويحتضنوه ويطمئنوه حتى يعود لفراشه وينام،

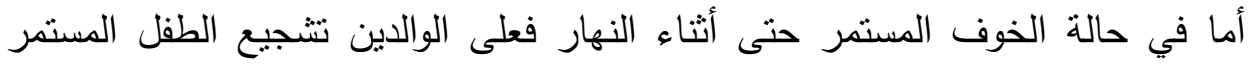

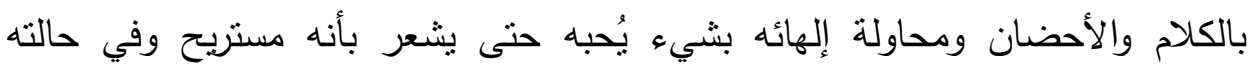

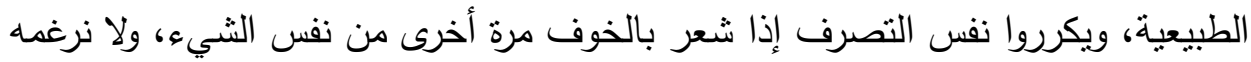
على هذا الثيء بل نغدق عليه بالحب والحنان والتشجيع، وهكذا يستطيع الطفل التغلب

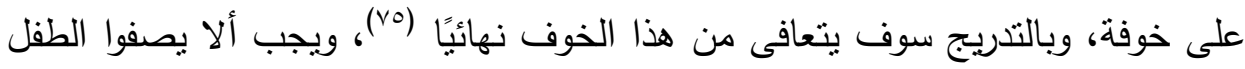
بالجبن بل يشجعوه دائيًا على القوة والإقدام والثجاعة، وحتى لو كانا الوالدين يخافان من لئن

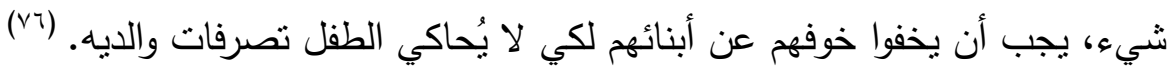
r - سلوك عدم الطاعة والإعتراض الدائم: على الوالدين ألا يقوموا بإصدار الأوامر للأطفال

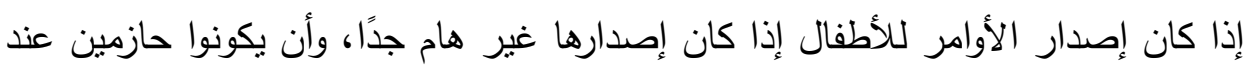

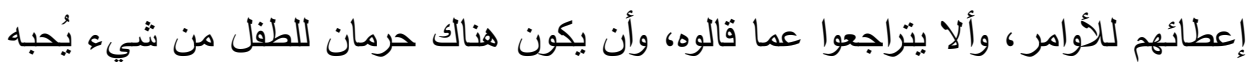

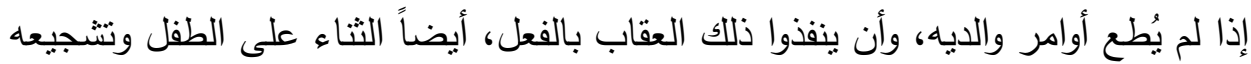

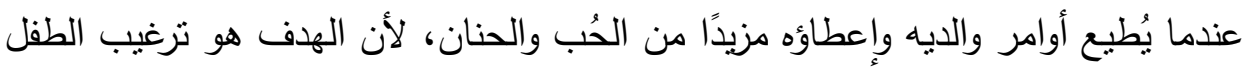

$$
\text { وليس ترهيبه (vV) }
$$

r- مشكلة العدوانية: على الوالدين ألا يستجيبوا لعدوانية الطفل لو كان يهدف من ورائها

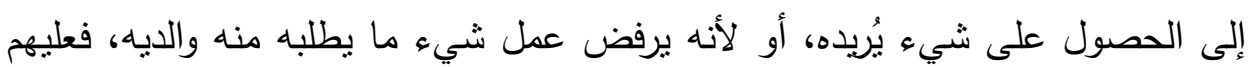

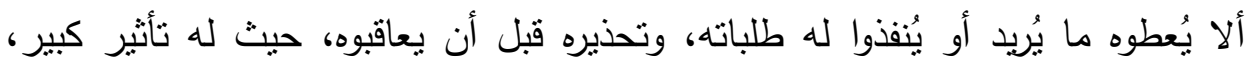

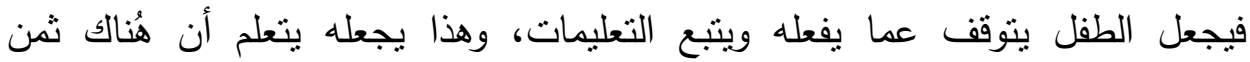
للعدوانية، ايضاً مدح الطفل وتتجيعه عندما يتحسن سلوكه حتى لايفهم أن أسلوب العقاب هو الغالب، وتعليمة الطرق السليمة للحصول على ما يُريده منل الإستئذان والتعاون ومساعدة الآخرين، وعدم الجدال الكثير معه خاصة لو كان على خطأ لأن ذلك اللك

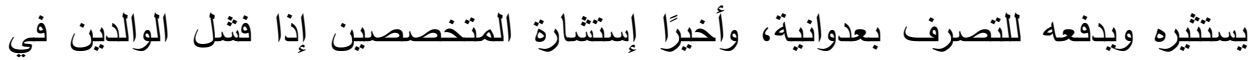

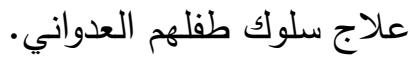


ع - مشكلة النشاط الزائر وقاة التركيز: من طرق علاج هذه المشكلة الإهتمام بطعام الطفل، حيث أن له دور فعال في علاج النشاط الزائد، فلقد سجلت الدراسات أن الأطفال

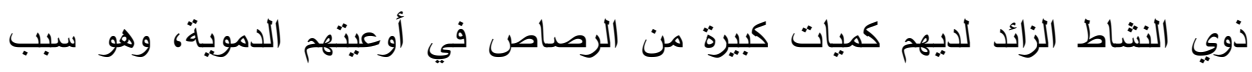
رئيسي لنشاطهم الزائد، وتتجيع الطفل على الهدوء والجلوس والإستقرار لفترة في مكانه

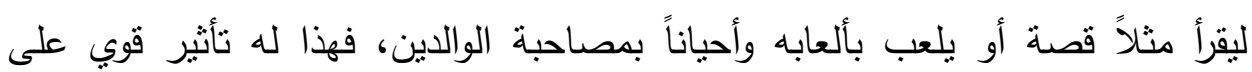

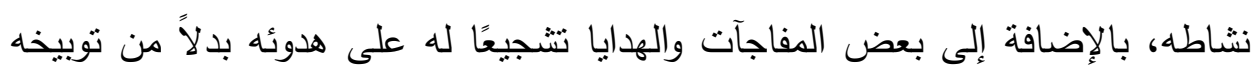

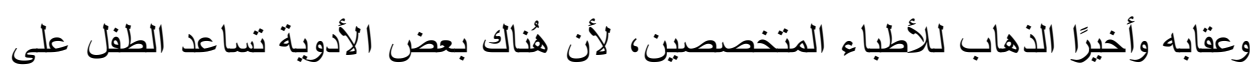

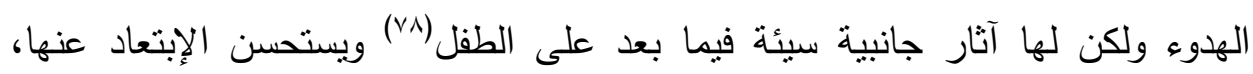

$$
\text { وإنباع الإرشادات السابقة. }
$$

ه- مشكلة الشعور بالنقص والإنطواع: يرى أساتذة الطب النفسي أنه في حالة اعوجاج سلوك الطفل أو كثرة أخطاؤه، لا يجب اللجوء إلى تعنيفه أو تحقيره أو نعته بكلمات قاسية، بل نتبع معه السلوك الحسن والرفق والليل والحوار الهذائ لمعالجة المشكلات

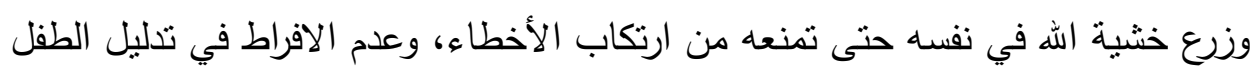

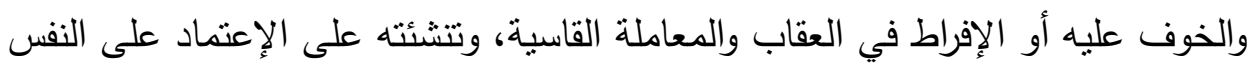
وتحمل المسئولية، والمساواة بين الأطفال وعدم المفاضلة والتميز بينهم، وإذا كان الطفل ولفيل

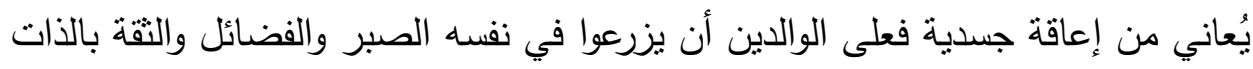

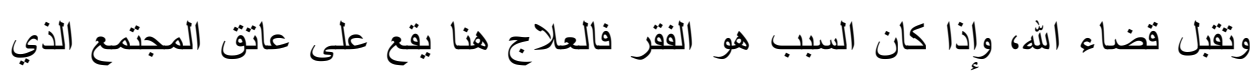

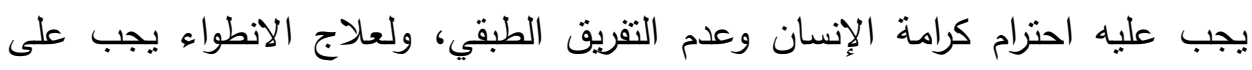

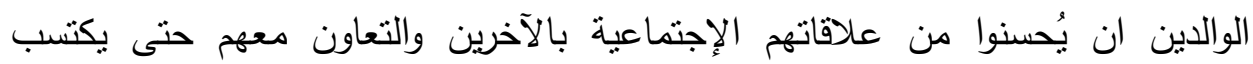

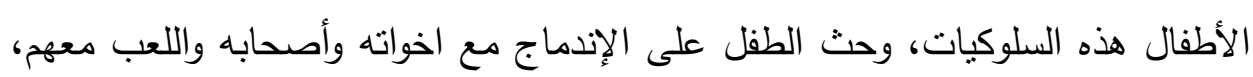

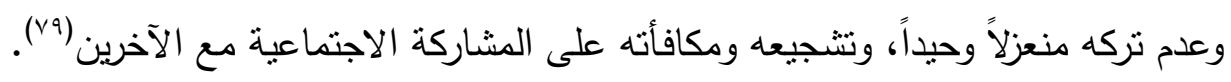

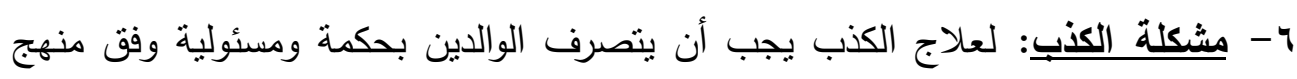
التعاليم الإسلامية أمام أطفالهم لكي يكونوا قدوة حسنة لهم وألا يكذبوا أمام أبنائهم، وأن لئه

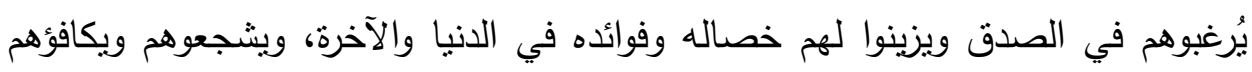

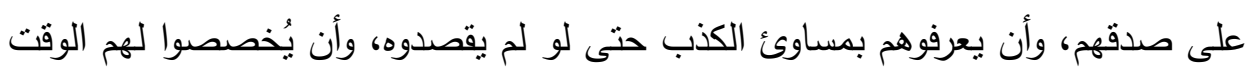
الكافي ليجلسوا معهم، وأن يعاملوهم برفق ولين، وألا يطلبوا منهم ذكر لئه التفاصيل

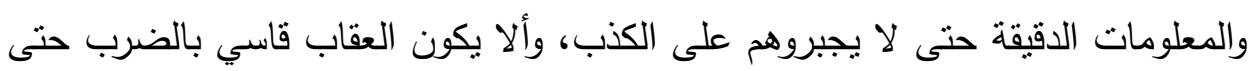


لا يضطر الطفل للكذب، وألا يفرقوا في المعاملة بين أطفالهم ، وأن يعرفوهم الفرق بين

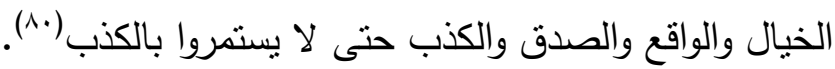

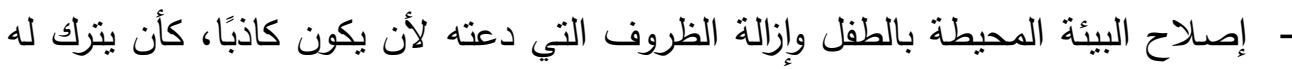

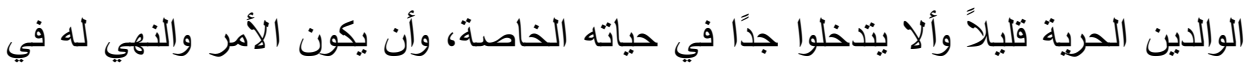
حدود المناسب، وتقوية الإعتماد عليه وعلى ذاته وأن يُهيئوا له جوًا من الثبات والإستقرار

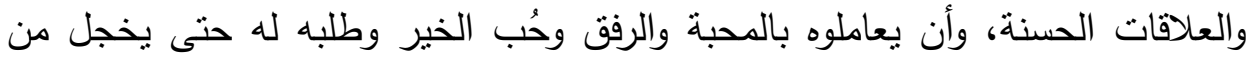

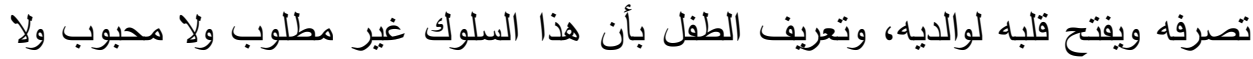
يجب نكراره حتى في أصعب الظروف، وأن يقول الصدق مهما كانت الظروف ونُشجعه ونهان

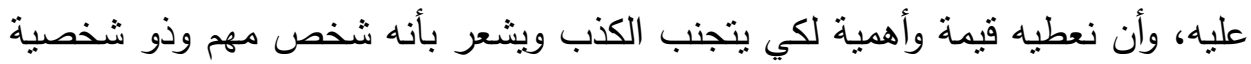

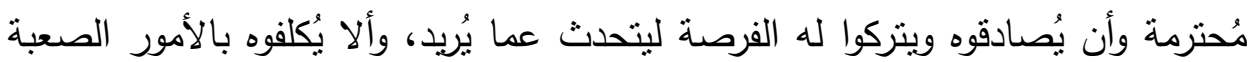

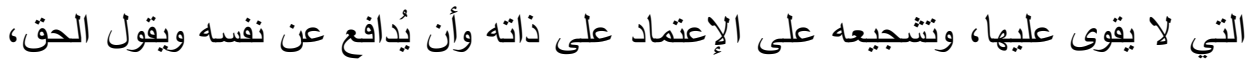

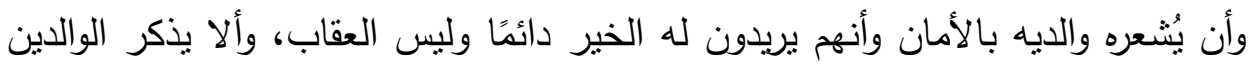

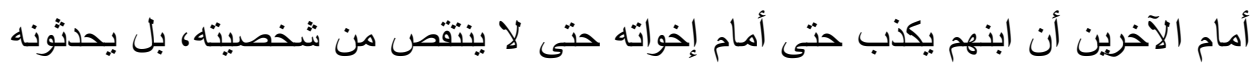

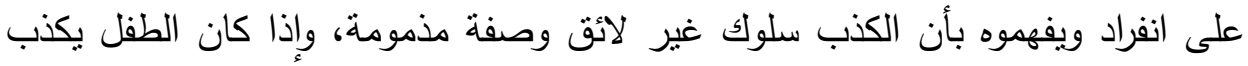
بهدف إضحاك والديه أو جلب تعجهم واستغرابهم لما يقول فيجب عليهم إهمال كذبه وعدم الإعتاء به، ويكتقوا بأن ينظروا إليه نظرات لوم وتوبيخ حتى يفهم أنهم يعترضون

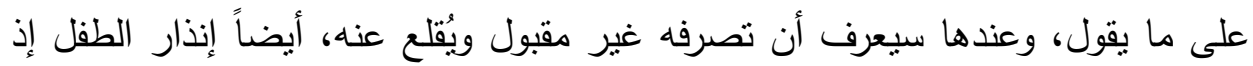

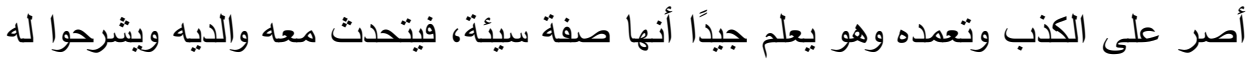

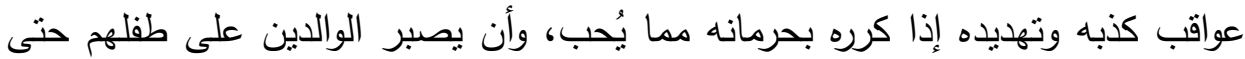
يتخلص من هذه العادة السيئة (1). V- مشكلة الغيرة الثدبدة: على الوالدين عدم التقرقة والعدل والمساواة بين أطفالهم في

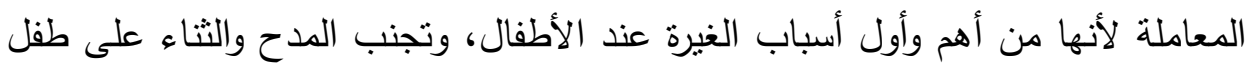

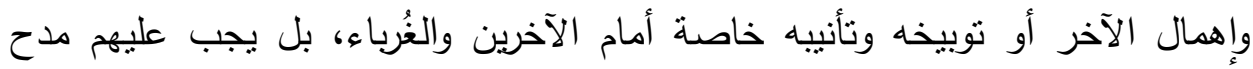
الطفل الغيور أكثر على أي شيء جيد يفعله حتى يشعر بالثقة في نفسه وعدم اهتزاز

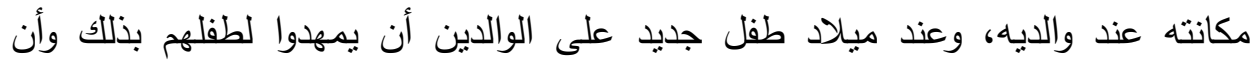

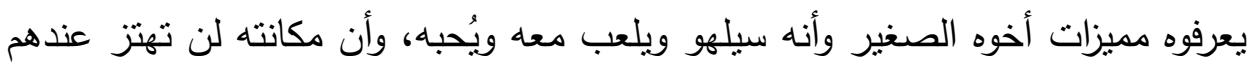

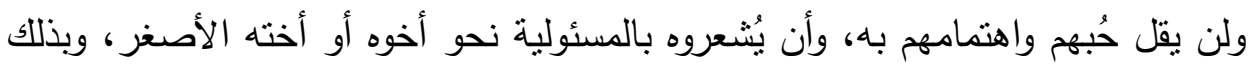


يترقب ميلاده بفرح وانتظار ، ويُساهم معهم في العناية به دون إزعاج أو قلق، مع ملاحظة

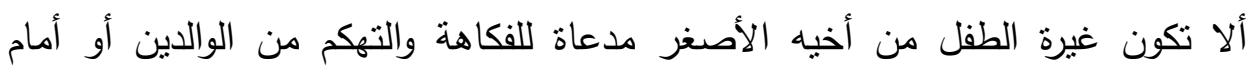

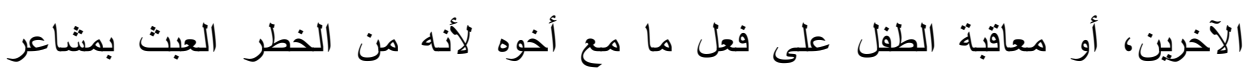

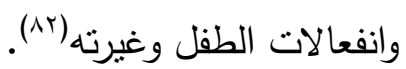

^- مشكلة السرقة: لعلاج مشكلة السرقة لابد من إكساب الطفل صفة الأمانة ومُراقبته عن بُعد، ومعرفة أصدقائه وكافة نشاطاته خارج المنزل، وأن يكون الوالدين قدوة لأبنائهم، وأن

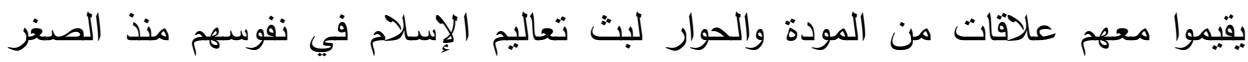

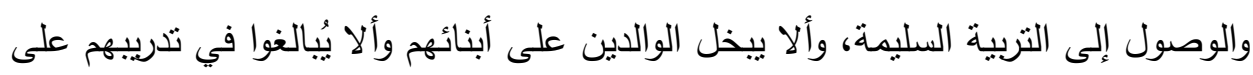

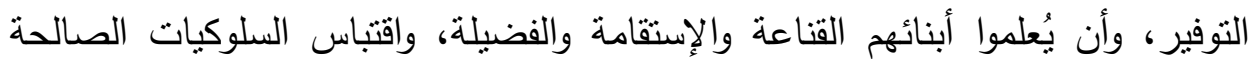
والأخلاق الحسنة من الآخرين، وتوجيه نشاط الأطفال إلى جهة اجتماعية تربوية سليمة وزرع بذور الخير في نفوسهم، والبعد عن عقابهم وتعنيفهم.

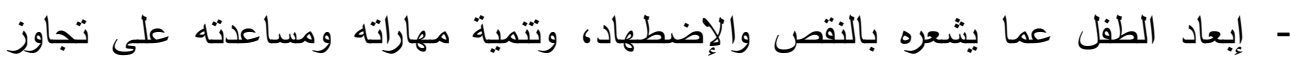
أخطاؤه حتى يثق بنفسه، وتجنب السخرية منه أو وصفه بالاجرام، وأن يواجه الوالدين والإنيه

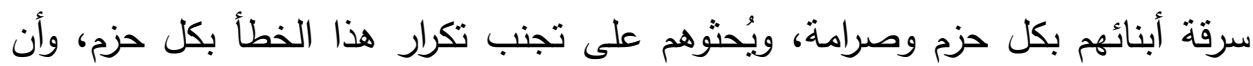
يكون هنالك عقاب بالحرمان مما يُحبه الطفل إذا كرر هذا الخطأ، وأن يتابع الوالدين بـاني

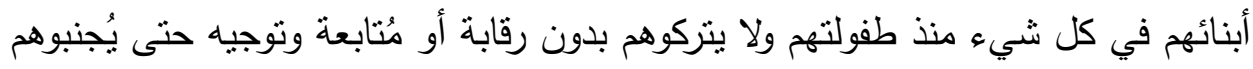

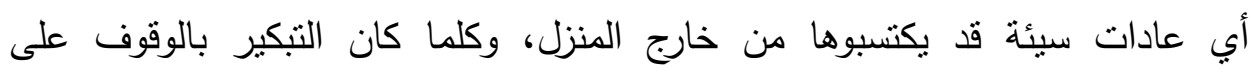

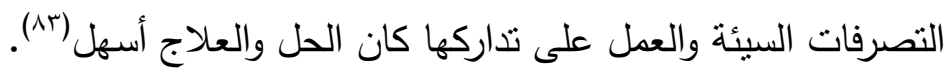

9 - مشكلة إدمان وسائل الإعلام الجديدة: لتجنب مخاطر وسلبيات وسائل الإعلام الجديدة،

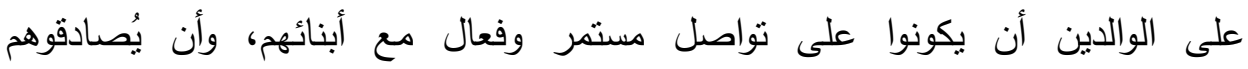
ويصاحبوهم ليكونوا مؤثرين في حياتهم وعلى علم بكل شئونهم لكي يستطيعوا المحافظة

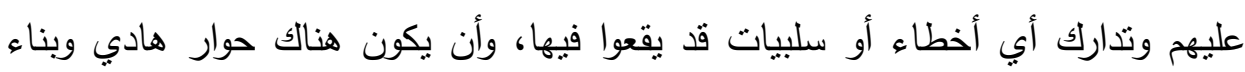

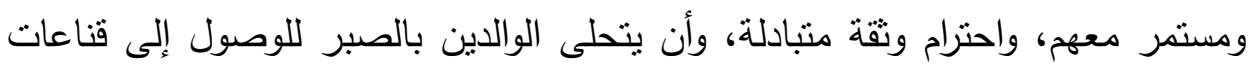

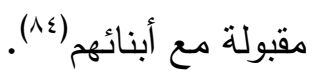

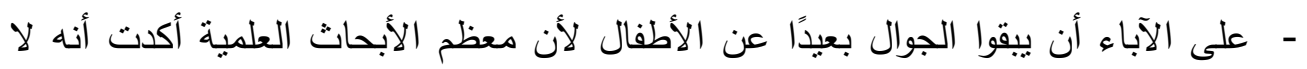

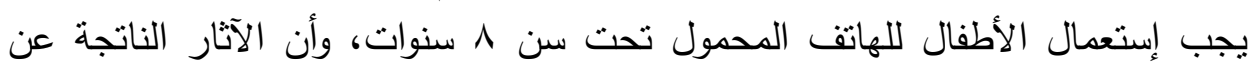

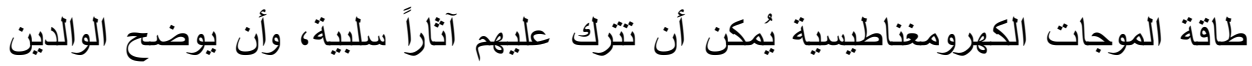




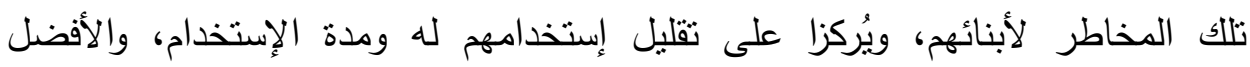

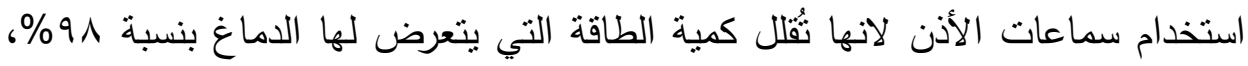

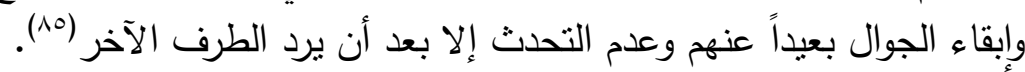

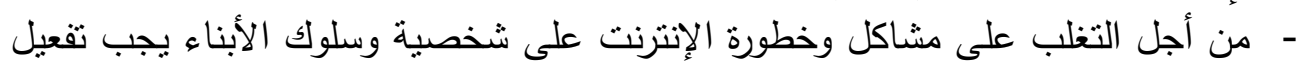

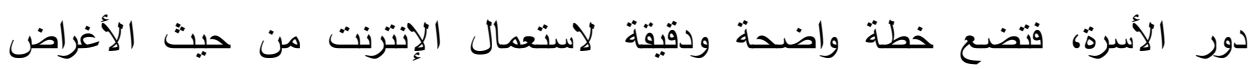

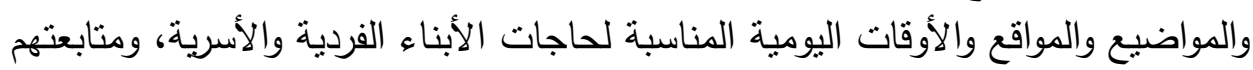

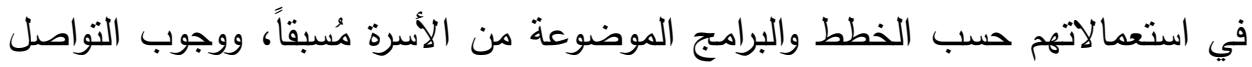

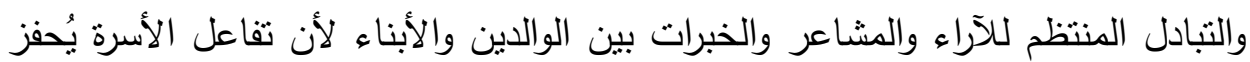

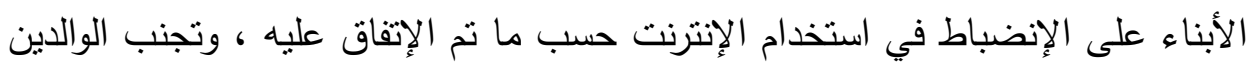

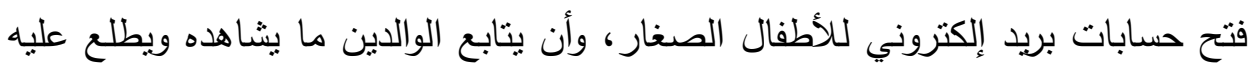

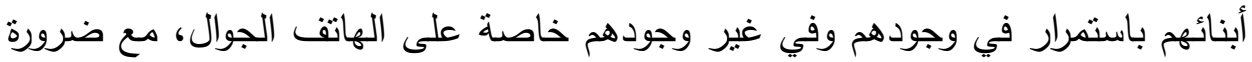

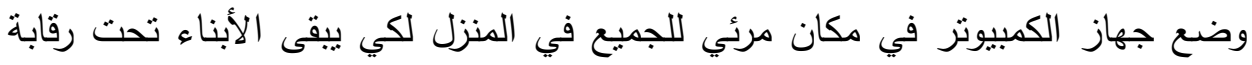

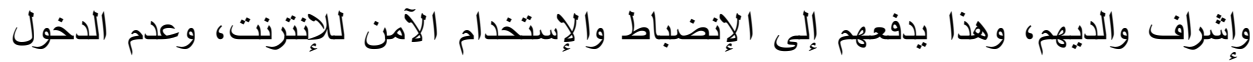

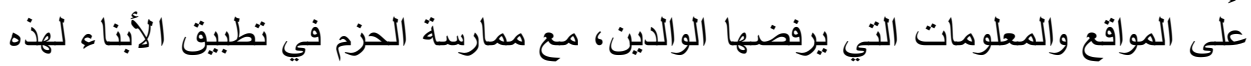

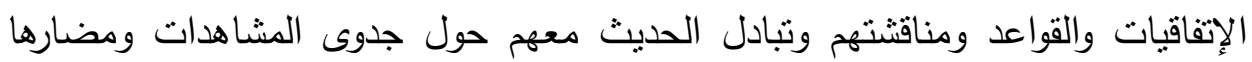

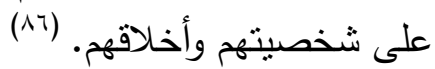
- ولعلاج مضار ومخاطر الألعاب الإكترونية على الوالدين فحص محتواها جيدًا والتحكم

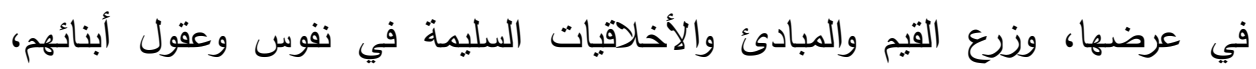

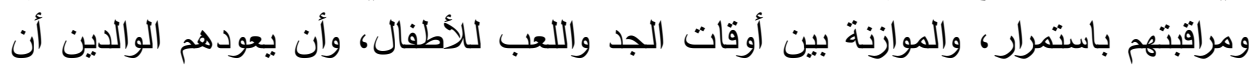

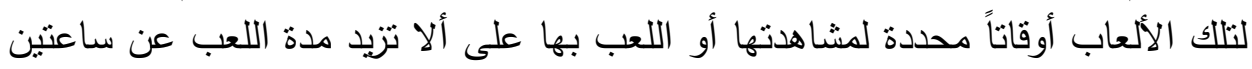

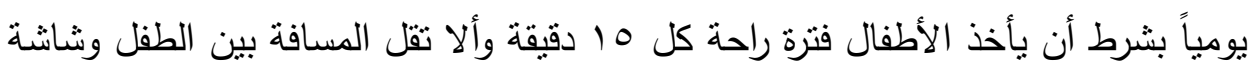

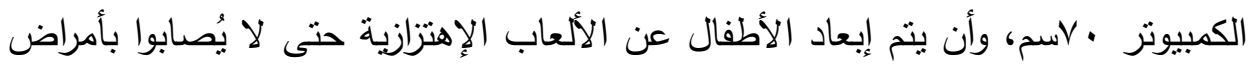

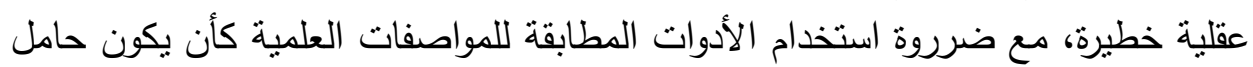

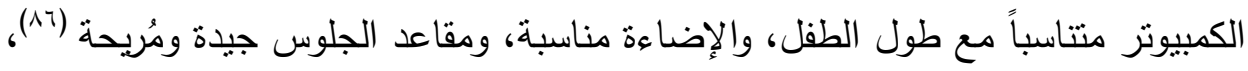

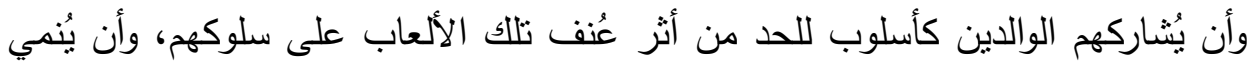

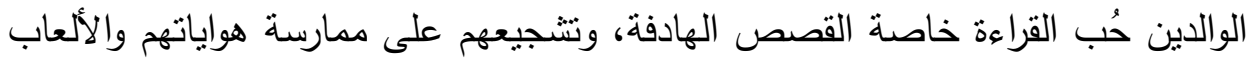
الرياضية، وتخصيص أوقات مُحددة للنسلية والترفيه والخروج من المنزل الفئل وزيارة الأصدقاء والأقارب.

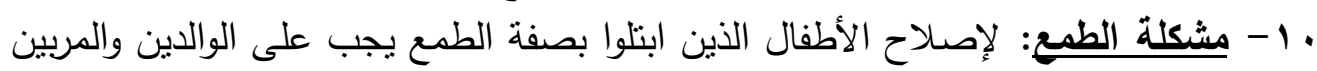

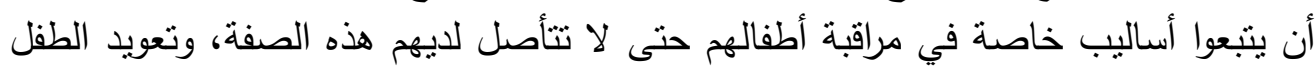

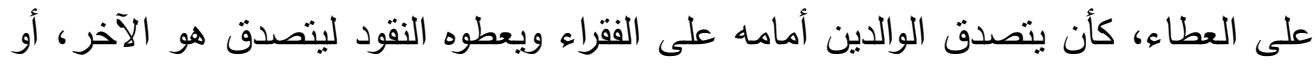

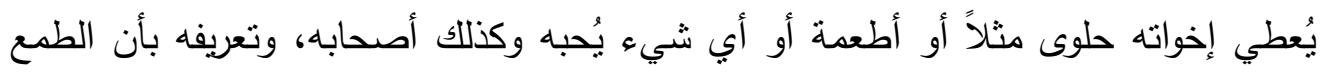

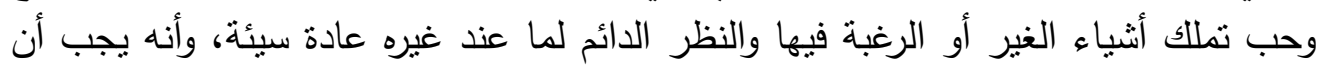


يكون قنوعاً بما عنده، ويحكي له الوالدين قصص عن الجود والكرم واعطاء الفقراء والمحتاجين

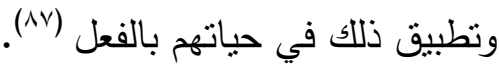
- خلق شعور لدى الطفل بمراقبة نفسه ومخالفة هواه عندما يتغلب عليه الحرص الثنديد،

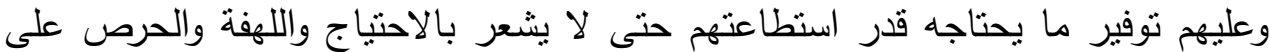
المال وتعويده عل القناعة ، مع تذكر الطفل بالنظرات الهادفة التي تتم عن الإنذار لو لو استمر في ذللك فإنه سوف يفقد محبة والديه، مع ملاحظة ألا نُجبر الطفل على إعطاء الطاء

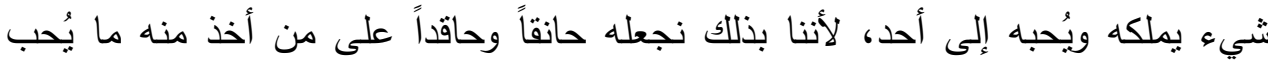

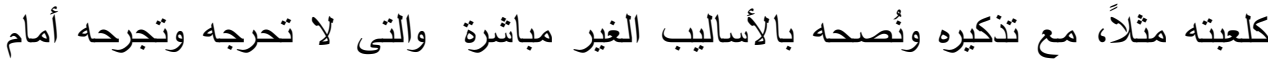

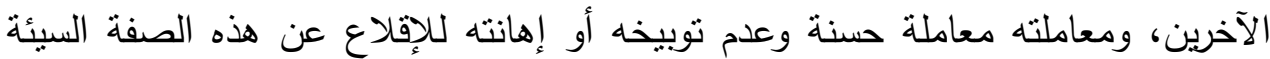

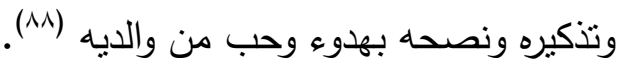

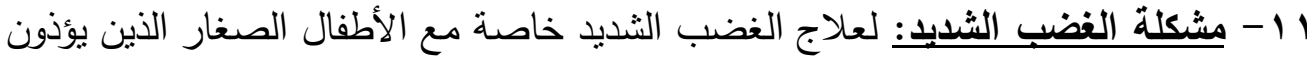

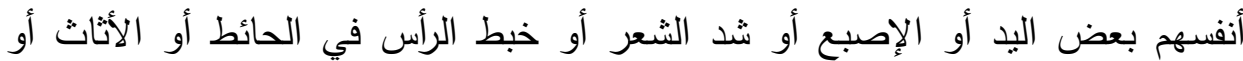

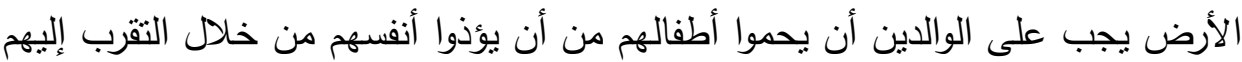

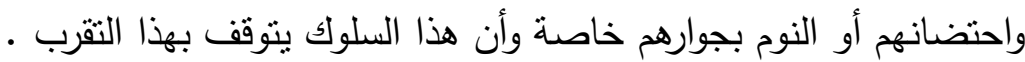
وإذا كان غضب الطفل الثديد بهدف الحصول على ما يُريد وعدم تتفيذ أوامر والديه

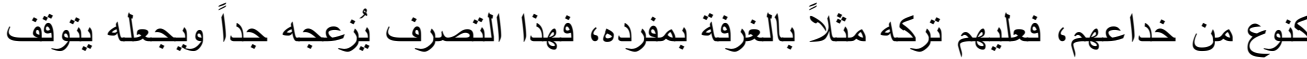

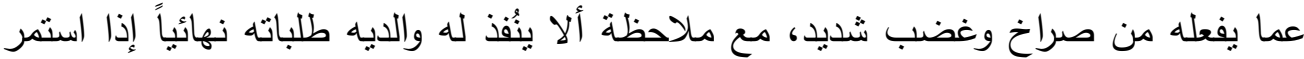

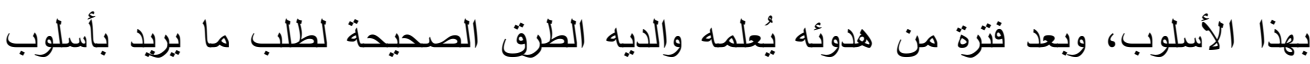
مهذب، وأن يكرروا ذلك مرات عديدة لكن ليس بعد الغضب مباشرة حتى لا يتعود أن هذا بلا لئه

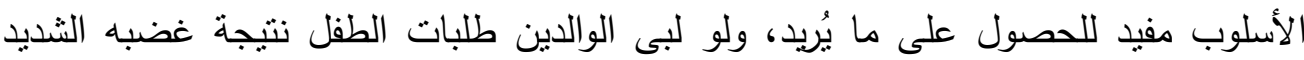

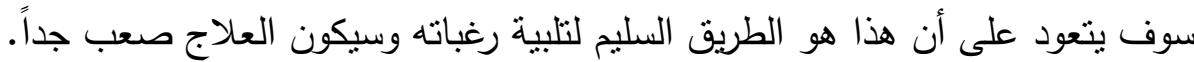

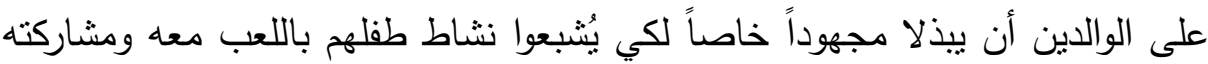

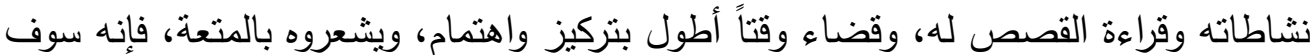

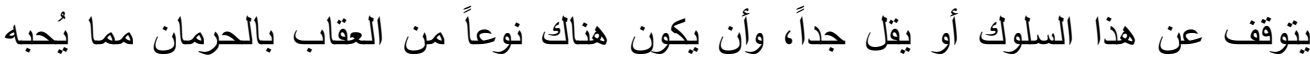

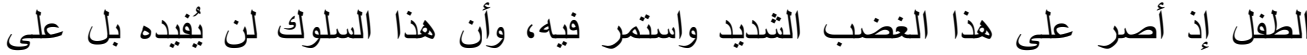

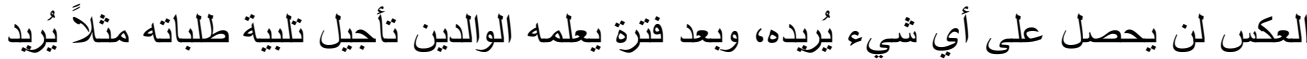

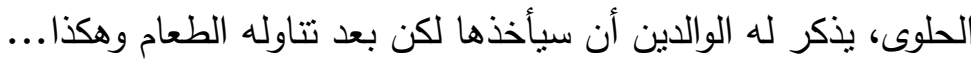

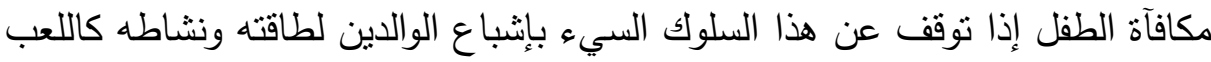

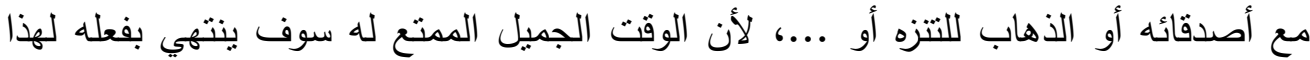

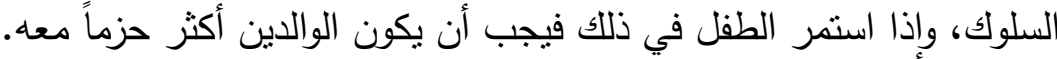
أخيراً إذا لم تتجح كل الخطط السابقة فلى الوالدين استشارة أخصائي نفسي للأطفال

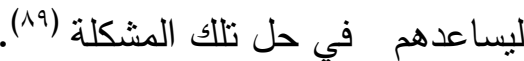


r ا- مشكلة التبول اللاإرادي : لعلاج مشكلة التبول اللاإرادي شقين : شق نفسي إذا كانت

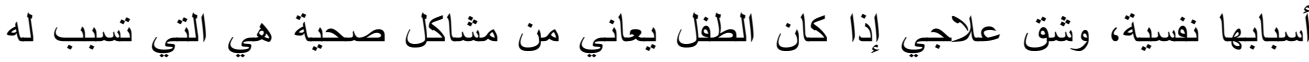

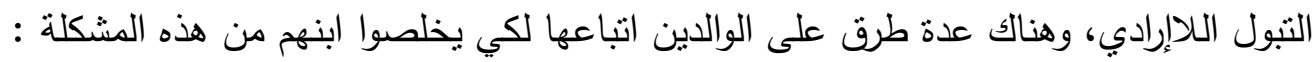

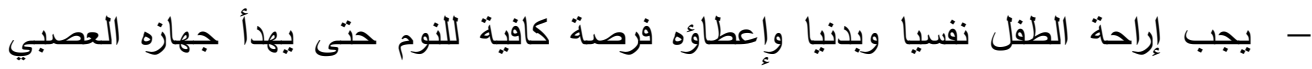

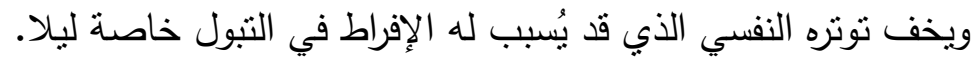

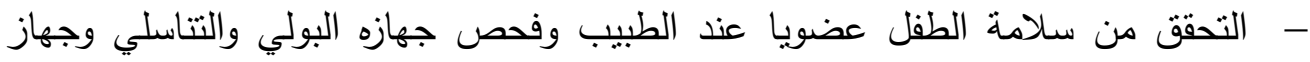

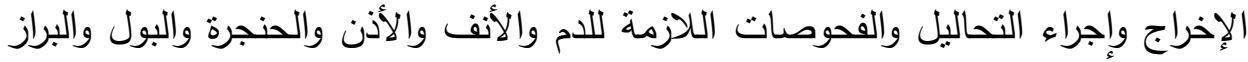
للتأكد من حالته الصحية. - - منع الطفل من تتاول السوائل قبل النوم بساعتين على الأقل .

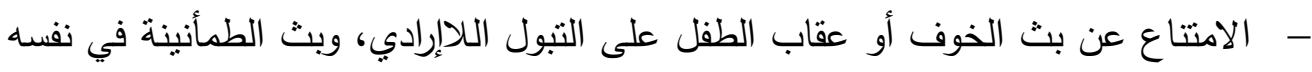

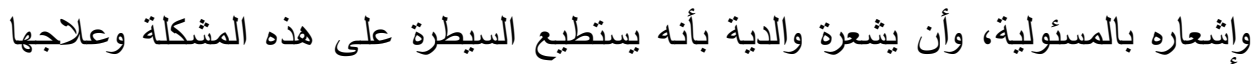
بنفسه وعدم التبول ليلا.

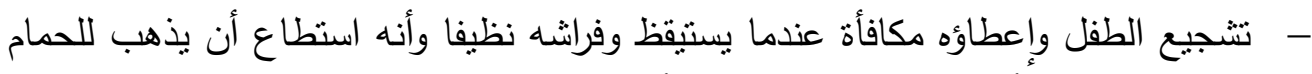

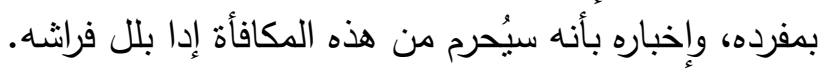

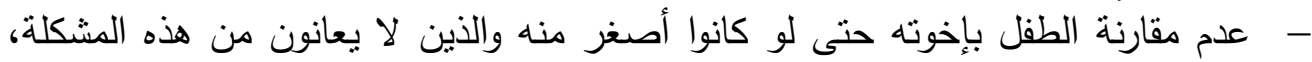

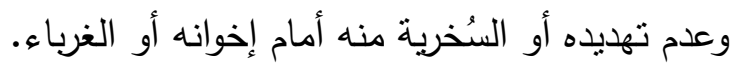

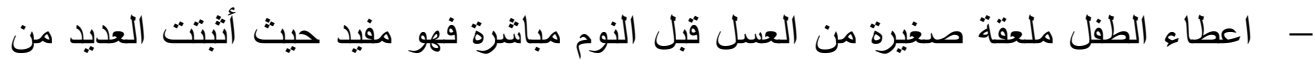

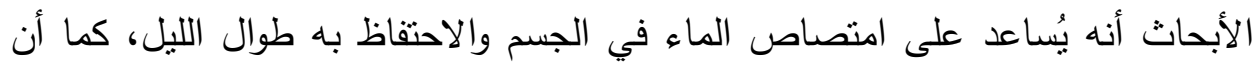

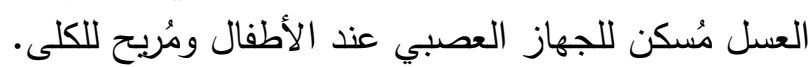

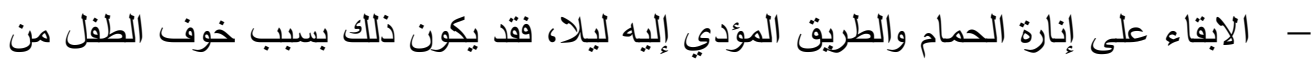

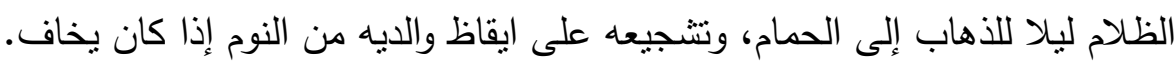

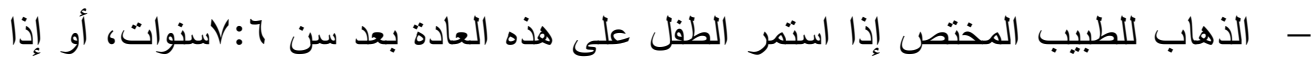

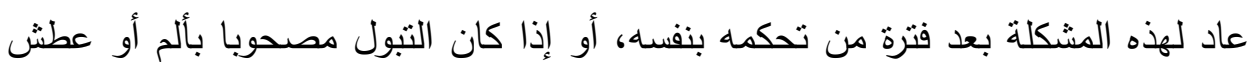

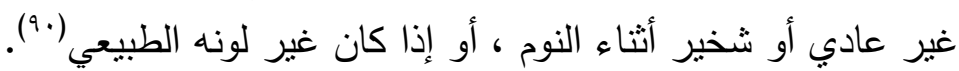




\section{مصادر الاراسة ومراجعها :}

() مهني محمد إبراهيم غنايم: " الوالدية والتربية البيئية والجمالية في ضوء الروية الكونية الحضارية

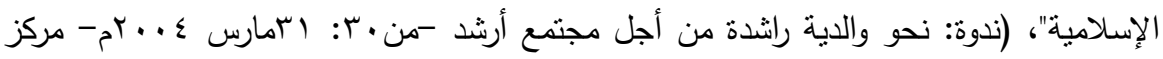

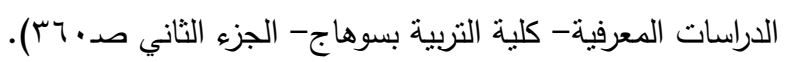

r) بركات عبدالعزيز محمد : " تأثير الأنترنت في التفاعل العائلي- قراءة في توجهات البحوث العلمية"، (المؤتمر العلمي الأول : الأسرة والإعلام وتحديات العصر - جامعة القاهرة- كلية الإعلام: من فئن

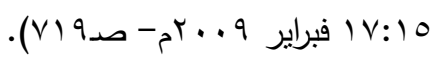

r) عبد العزيز الخضراء : "من يربى أبنائنا في هذا الزمن؟"، (دار القس للعلوم والطباعة والنشر والتوزيع-

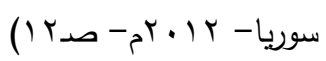

ع) سحر ناجي الناجي : " كيف نربين طفلك في ظلال التربية الإسلامية؟"، ( طا- دار طويق للنشر

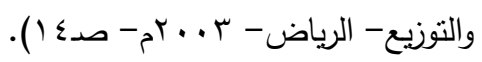

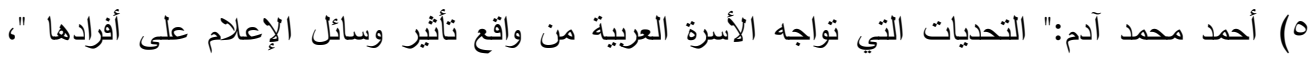

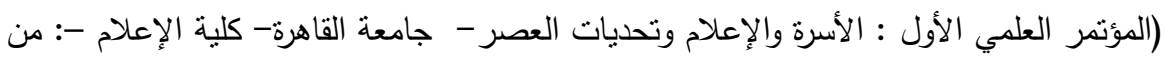

$$
\text { (V:10 } 10
$$

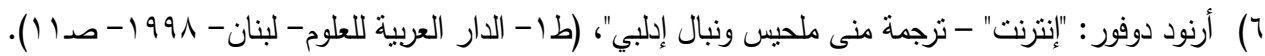

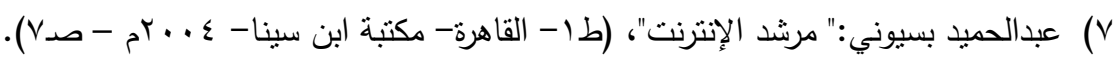
^) محمد إسماعيل نشاوي وهيثم مرجان: " إنترنت للمبتدئين - كتابين في كتاب"، (ط إ- سوريا- دار البراق

$$
\text { ودار القلم العربي- ع . . ب-صد • ( ). }
$$

9) فتحي حسين عامر :" وسائل الإتصال الحديثة من الجربدة إلى الفيس بوك"، (طا - القاهرة- العربي للنشر

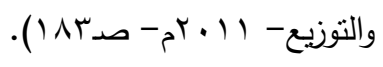

• ()شريف اللبان: مداخلات في الإعلام البديل والنشر الإكتروني على الإنترنت"، (ط إ- القاهرة- دار العالم

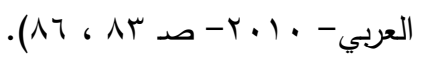

(1) عبدالصادق حسن :" إلتماس الثباب الجامعي الخليجي للمعلومات من المواقع الإلكترونية الثشعية- دراسة مقارنة على عينة من طلاب جامعتى البحرين والكويت"، (المجلة العربية لبحوث الإعلام

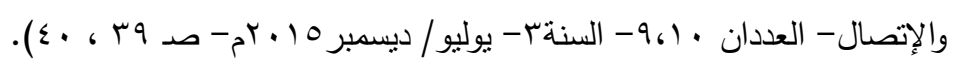

با زكريا الثربيني ويسرية صادق: " تنشئة الطفل، وسبل الوالدين في معاملته ومواجهة مشكلاته"، (القاهرة-

$$
\text { دارالفكر العربي- . ... بم- صده). }
$$

با (منير عامر وشريف عامر :" تربية الأبناء في الزمن الصعب"، (دار العلم للملايين - بيروت-لبنان- طا -

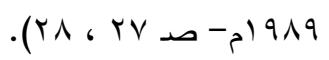

ع ()حسن عماد مكاوي وليلى حسين السيد: "الإتصال ونظرياته المعاصرة"، (ط9 - الدار المصرية اللبنانية-

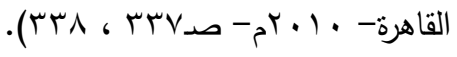


1) إيمان حسني: " إلتماس المعلومات السياسية من شبكات التواصل الإجتماعي وعلاقته بالاتجاهات التعصبية لاى الثباب المصري الجامعي"،" دراسة في ضوء مداخل التماس المعلومات والتوازن والتصنيف المعرفي" ، (المؤتمر العلمي الدولي التاسع عثر لكلية الإعلام- جامعة القاهرة-

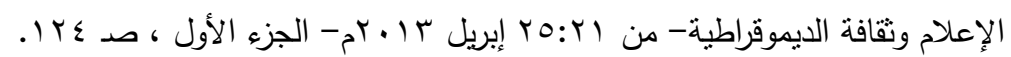

16) Lokman I meho, Stephanie w.Haasm 2001 I information seeking Behavior and use of social sciences faculty studying stateless Nations: acase study, library \& I information sciences Research, vo123,p 10.

17) Elizabeth Karras, lamce S.Rintam aki, 2012,an Examination of online Health irformation seeking by Deaf people, Health, communication, 27:195.

^ 1 )حسن عماد مكاوي وليلى حسين السيد: "الإتصال ونظرياته المعاصرة، مرجع سابق، صدمبس.

9 (1)عبدالصادق حسن:" إلتماس الثباب الجامعي الخليجي للمعلومات من المواقع الإكترونية الثيعية، مرجع

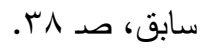

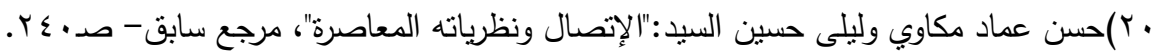

(Y)مصطفى عبداله الجزيري وآخرون: استخدامات المرأة الصعيدية للشبكات الاجتماعية وتأثيرها على ولى

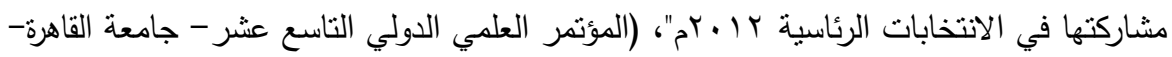

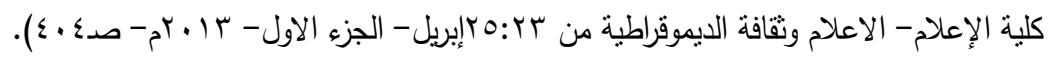

r r)نوره حمدي محمد أبو سنة: استخدام الشباب السعودي للهواتف الذكية والاثباعات المتحققة منها"، (المجلة

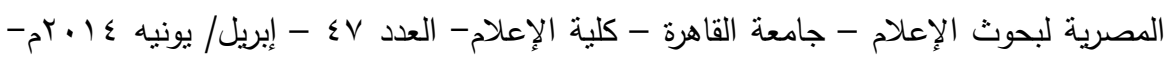

$$
\text { • صدros) }
$$

23) Katz,E., M.Gurevitch, and H.Hoas (1973). On the use of the mass media for important thing S.American Sociological Review, 38:164-181.pp.166-167

24) MC quail D,J.G.B lumler and J.R.Brown (1972). The television audience: Arevised perspective.

25) D.N.C Quail, ed, sociology of mass communications, pp.135-165. Harmonalsworth, Eng: penguin.

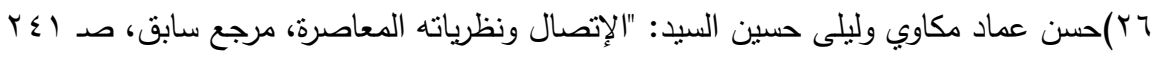

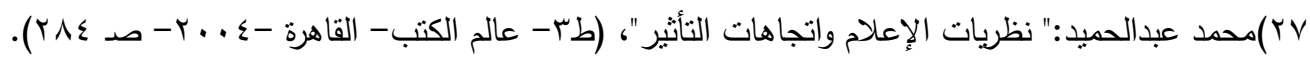

28) Munira Nasreen, Information Needs and seeking Behavior of Media Practitioners: A Case of Media Practitioners Working in Radio, TV and News, paper Houses of Karachi, VDM publishing, 2011,p:91

29) Rajiv N. Rimal, Achieving Improvements in Overall Health Orientation Effects of Campaign Exposure, Information seeking, and Health Media Use, Communication Research, vol. 26 no. 3, June 1999, p: 320

• ץ)عبدالصادق حسن:" إلتماس الثباب الجامعي الخليجي للمعلومات من المواقع الإلكترونية الثيعية-دراسة 320

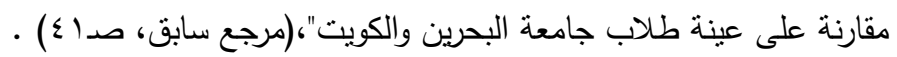
اب)شريف درويش اللبان: مداخلات في الإعلام البديل والنشر الإلكتروني على الإنترنت"، (طا (- القاهرة- دار

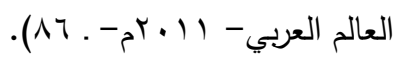


rr)|إيمان حسني: " إلتماس المعلومات السياسية من شبكات التواصل الإجتماعي وعلاقته بالاتجاهات التعصبية لدى الثباب المصري الجامعي" دراسة في ضوء مداخل التماس المعلومات والتوازن

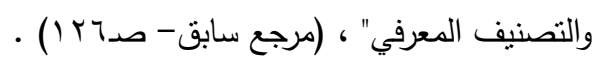

بr)شريهان محمد توفيق: "العوامل المؤثرة في إلتماس المعلومات السياسية من شبكة الإنترنت- دراسة ميدانية

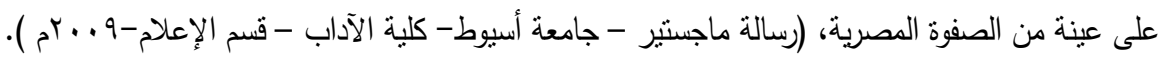
عץ)إيمان حسني: " إلتماس المعلومات السياسية من شبكات التواصل الاجتماعي وعلاقته بالإتجاهات التعصبية لدى الثباب المصري الجامعي"، (المؤتمر العلمي الدولي التاسع عشرلكلية الإعلام-

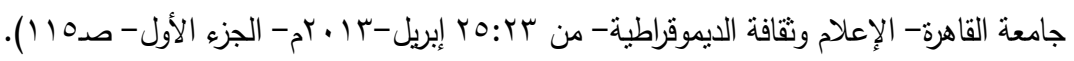
هب)داليا ابراهيم الدسوقي المدبولي: "إلتماس المعلومات السياسية من مواقع التواصل الإجتماعي وعلاقتها بمصداقية المضمون لاى دارسي الإعلام التربوي بالجامعات المصرية"، (المجلة المصرية لبحوث

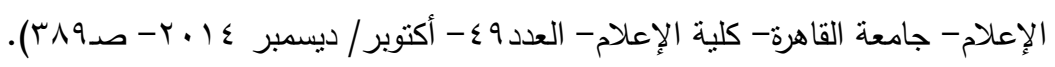

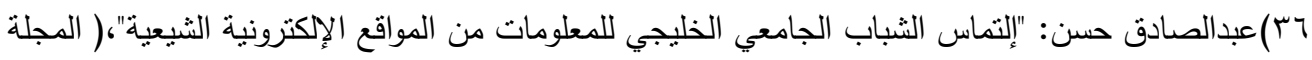

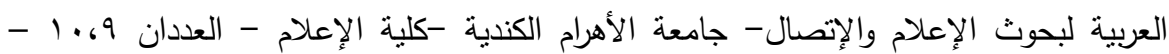

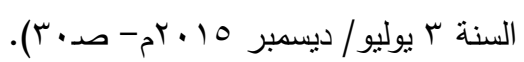

37) Ann Romine Poteet, Newspaper journalists- " Information seeking Behavior with online Information sources, M.A thes is (North Carolina: university of North Caroline, faculty of the school of information and library science, 2000).

38) R.J.W. Cline K.M.Haynes. Consumer health information seeking on the Internet: the state of the art. Health Education Research, Volume 16, Isse 6,1 December 2001, pages 671-692

39) Wester main \&others, How do people Really seek information About others : information seeking Across internet and traditional communication sources, "paper presented to Annual Meeting of the International communication Association", (TBA, san Francisco, CA, 23-5-2007).

40) Tom Heath, BSC, information seeking on the web with trusted social Networks- from theory to systems, doctor of philosophy in computer sicien ca , Knowledge media institute, 14-1-2008.

$$
\begin{aligned}
& \text { (ا)منى جابر عبدالهادي هاشد: استخدام الثباب الجامعي للمواقع الإلكترونية الإسلامية على شبكة الإنترنت }
\end{aligned}
$$

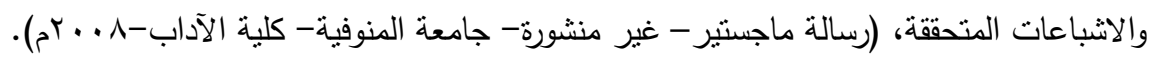

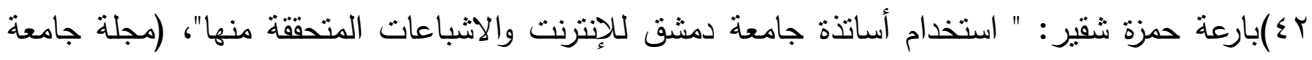

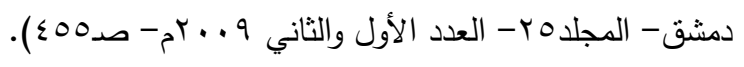

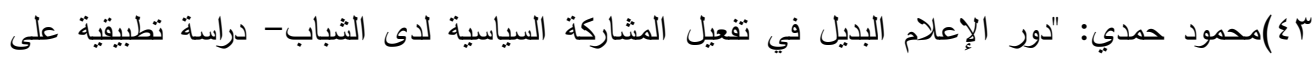

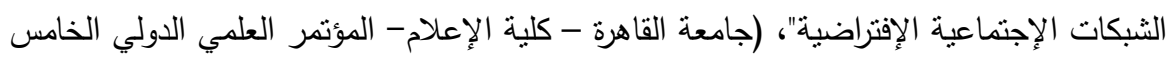

$$
\text { عشر - الإعلام والإصلاح: الواقع والتحديات- } 9 \text { ه . rم). }
$$


؟ ؛)نرمين زكريا خضر : " الآثار النفسية والإجتماعية لإستخدام الثباب المصري لمواقع الثبكات الإجتماعية -

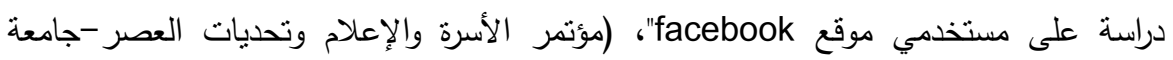

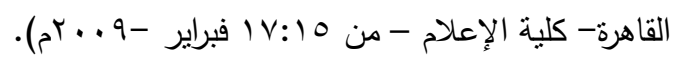

0؛)حمزة السيد حمزة خليل:" استخدام الثباب مواقع الثبكات الاجتماعية لإطلاق ثورة هب يناير المصرية والاثباعات المتحققة منها - دراسة ميدانية"، (رسالة ماجستير غير منشورة- جامعة طنطا - كلية

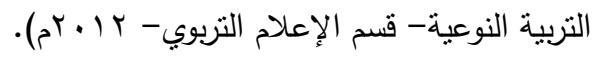

7؛)حنان شعشوع الثهري:" أثز استخدام شبكات التواصل الإكتروني على العلاقات الاجتماعية- الفيس بوك وتوينز نموذجاً"، (رسالة ماجستير المملكة العربية السعودية - جامعة الملك عبدالعزيز - كلية

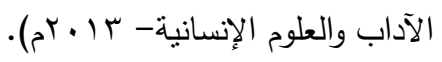

\&V)محمود أحمد لطفي وهاجر شعبان سعداوي:" استخدام الشبكات الاجتماعية في تعبئة الرأي العام أثناء الأزمات السياسية الطارئة- أزمة الدستور المصري نموذجاًا،( القاهرة- جامعة الأهرام الكندية-

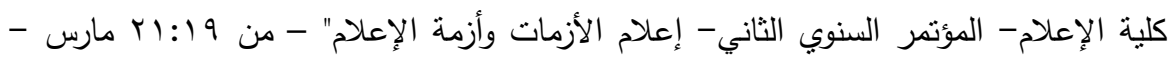

$$
\left.\cdot()^{2} \cdot 1\right)
$$

^§)مصطفى سيد عبد اللاه الجزيري ومحمود أحمد لطفي ونورة عبداله محمود: استخدامات المرآة الصعيدية

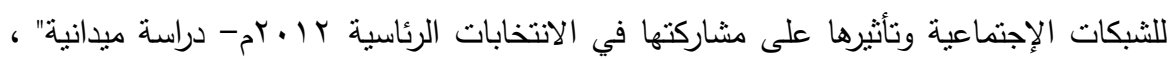
( المؤتمر العلمي الدولي التاسع عشر - الإعلام وثقافة الديموقراطية" - جامعة القاهرة - كلية

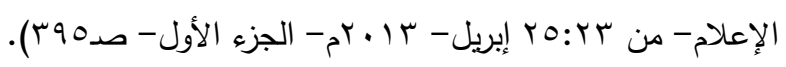

9ء)أمل السيد أحمد دراز:" استخدامات شبكات التواصل الإجتماعي وتأثنرها على الآداء المهني للقائمين

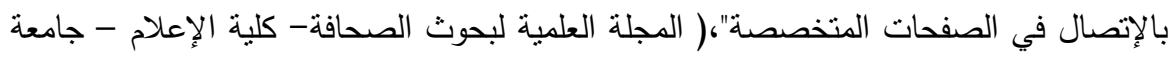

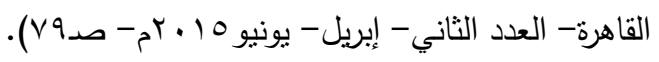

• ()سلمى إبراهيم محمد شاهين:" دور الثبكات الإجتماعية في نوعية المرأة بالقضايا الإجتماعية"، ( جامعة

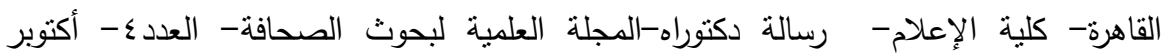

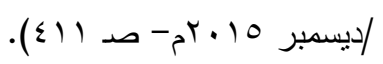

10)منى جابر عبدالهادي:" المعايير المهنية والأخلاقية وعلاقتها باستخدام الجمهور المصري لمواقع التواصل

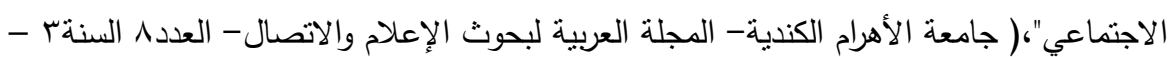

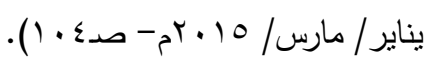

52) Nicole .B.Ellison "the Benefits of face book" Friend social capital and college students" use of online social Network sites journal of computer- mediated communication -2007.

53) Kanakara Navasortion, Digging for votes : an analysis of 2008 presidential candidates use of New media, Master thes is , califrnia, university of southern California, May 2008, pp.1-3

54) Tufekci, Zeynep. Grooming, gossip, facebook and may space, information, communication \& society, (4), aug.2008 
55) Monica \& cozma Roluca. My space politics uses and Gratification of Befriending candidates. "journal of Broadcasting \& Electronic Media". Vol.53, 4-11-2009. P.p.567.

56) Kathleen Sara Alpiza. New Media use among high achieving adolescents, Master of science, son jos A state university: the faculty of the school of journalism and mass communications.

57) Keim, Kyle," follow the leaders: Newspaper journalists, Networks of Association an twitter "paper presented at the annual meeting of the Association for education in journalism and mass communication, st. Louis, 2011.

58) Pirjo Nakki \& Asta Back, social media for citizen participation, technical Research center of finland, 2011. www.vtt.fi/inf/pdf/publications/2011/p 755.pdf.

59) Cheung, C., Chiu ,p \& lee,m (2011)" online social network: why do students use facebook? "In computers in Human Behavior, vol (27), p.p 1337-1343.

60) Monica Ancu "older adults of facebook : Asurry

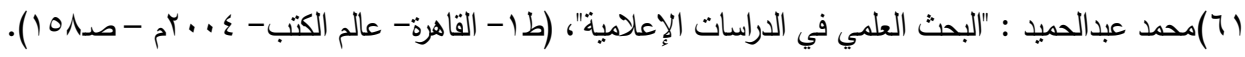
بآ)محمد شفيق :" البحث العلمي وتطبيقاته في مجال الدراسات الاجتماعية"، (الاسكندرية- المكتب الجامعي

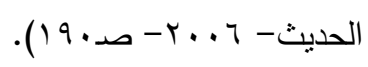

rآ) سماء بنت احمد البحيصي : الطفولة مشاكل وحلول: Educeatien-ingaza>edu.ps.www.pdffactory

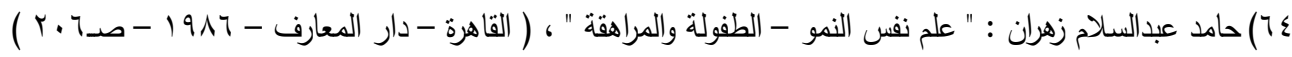
ه7)زكريا الشربيني ويسرية صادق: "تتسيق الطفل وسبل الوالدين في معاملته ومواجهة مشكلاته "، القاهرة -

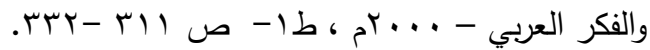

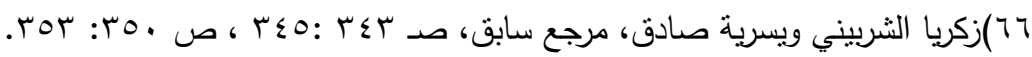

VT)سحر ناجي الناجي "كيف تربين طفلك ؟ في ظلال التربية الإسلامية" ، (الرياض- دار طويق للنشر

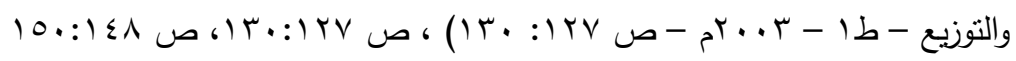

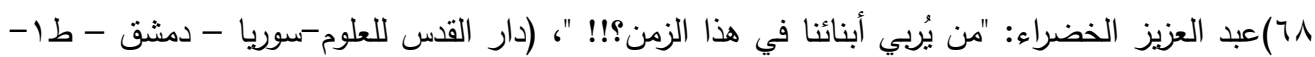

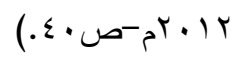

9 7)على القائمي: "الأسرة والمشاكل الأخلاقية للطفل"-ترجمة الكاظم الكاظمي، (دار النبلاءكبيروت - لبنان-

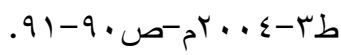

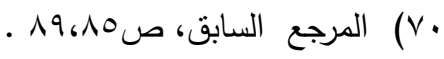

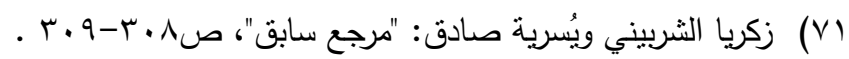

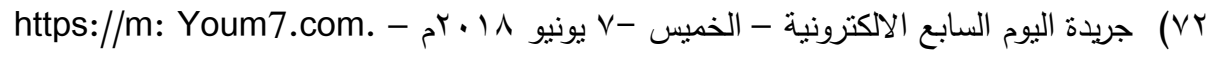

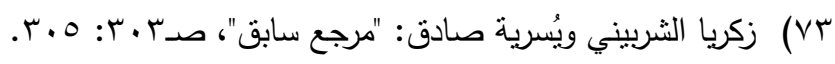

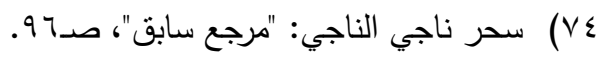

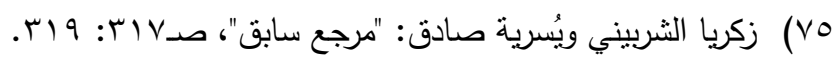

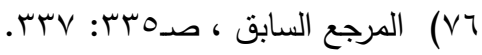




$$
\begin{aligned}
& \text { ( المرجع السابق : ص هrr:VV }
\end{aligned}
$$

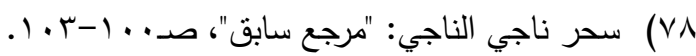

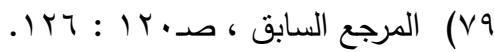

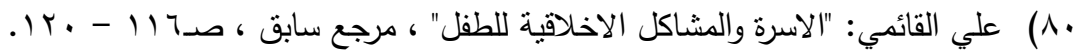

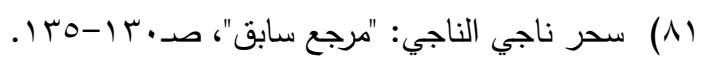

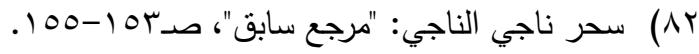

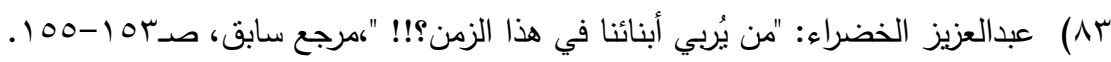

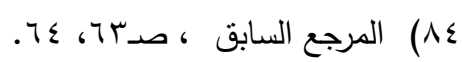

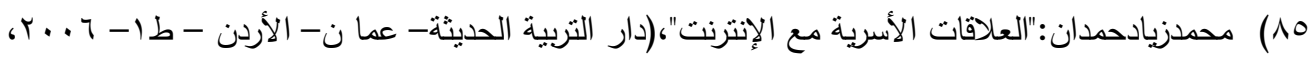

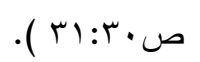

(A

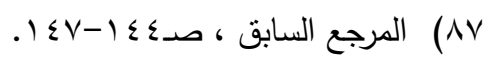

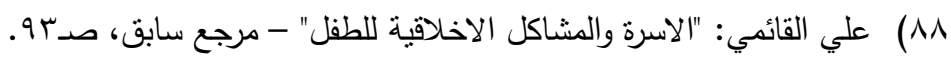

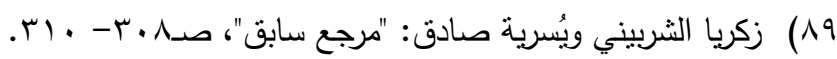

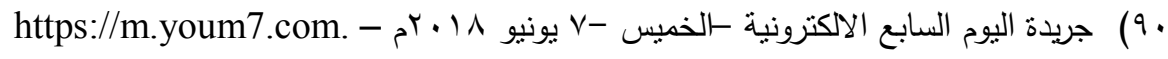

